$$
\text { UNIVERSIDADE DE SÃO PAULO }
$$

FACULDADE DE FILOSOFIA, LETRAS E CIÊNCIAS HUMANAS

DEPARTAMENTO DE LETRAS CLÁSSICAS E VERNÁCULAS

PROGRAMA DE PÓS-GRADUAÇÃO EM FILOLOGIA E LÍNGUA PORTUGUESA

\title{
A REPRESENTATIVIDADE DA VOZ DO TRABALHADOR NO DISCURSO JURÍDICO TRABALHISTA: ASPECTOS DA CONSTRUÇÃO DO SUJEITO SOCIAL TRABALHADOR
}

\section{Tatiana Piccardi}


UNIVERSIDADE DE SÃO PAULO

FACULDADE DE FILOSOFIA, LETRAS E CIÊNCIAS HUMANAS

DEPARTAMENTO DE LETRAS CLÁSSICAS E VERNÁCULAS

PROGRAMA DE PÓS-GRADUAÇÃO EM FILOLOGIA E LÍNGUA PORTUGUESA

\section{A REPRESENTATIVIDADE DA VOZ DO TRABALHADOR NO DISCURSO JURÍDICO TRABALHISTA: ASPECTOS DA CONSTRUÇÃO DO SUJEITO SOCIAL TRABALHADOR}

\section{Tatiana Piccardi}

Tese apresentada ao Programa de Pós-Graduação em Filologia e Língua Portuguesa, do Departamento de Letras Clássicas e Vernáculas da Faculdade de Filosofia, Letras e Ciências Humanas da Universidade de São Paulo, para obtenção do título de Doutor em Letras.

Orientadora: Profa. Dra. Helena Hathsue Nagamine Brandão

São Paulo

2005 
A Maurício, marido amado, e às jóias de minha vida: meus filhos Guilherme e Helena (in memoriam). 
Eu me contradigo? Pois bem, eu me contradigo.

Eu contenho multidões.

Walt Whitman

Há muitos diálogos

O diálogo com o ser amado

o semelhante

o diferente

$o$ indiferente

o oposto

o adversário

o surdo-mudo

o possesso

o irracional

o vegetal

o mineral

o inominado

O diálogo contigo mesmo

com a noite

os astros

os mortos

as idéias

o sonho

o passado

o futuro

Escolhe o teu diálogo

$e$

Tua melhor palavra

ou

Teu melhor silêncio

Mesmo no silêncio e com o silêncio

Dialogamos

Carlos Drummond de Andrade 


\section{AGRADECIMENTOS}

Ao escritório de advocacia trabalhista Mendonça Sampaio Advogados Associados, em especial à amiga e advogada Dra. Iara Sampaio, por terem aberto suas portas e me orientado em minhas investigações na área do Direito Trabalhista.

À minha orientadora e amiga, Helena Brandão, pelos conhecimentos partilhados, pela leitura atenta de cada versão, pela paciência e boa vontade; e aos meus colegas de curso, na USP, pela interlocução em cada encontro; em especial à colega e amiga Sônia Adão, pelas palavras de incentivo, pelas horas de estudo em conjunto, por sua contagiante determinação.

Aos colegas do Grupo Atelier, do LAEL/PUC-SP, com quem tanto tenho aprendido nos encontros anuais no InPLA e em outros momentos de saudável troca intelectual.

À Capes - Coordenação de Aperfeiçoamento de Pessoal de Nível Superior - pela bolsa concedida em momento crucial para a finalização do trabalho.

Aos funcionários do departamento, pela pronta ajuda prestada sempre que uma dúvida burocrática surgia.

À minha família, em especial ao meu marido Luiz Maurício, pelo apoio irrestrito; e à minha cunhada, amiga e professora de lingüística e língua inglesa, Anna Balocco, pelos auxílios nas traduções do português para o inglês.

Aos amigos que, embora distantes da vida acadêmica, valorizaram o esforço de elaboração deste trabalho, incentivando-me a cada etapa, em especial à Bia Toledo, pelas aulas de francês e pelo auxílio nas traduções.

A todos os que me circundam, que, sem saber, constituem laboratório vivo dos fenômenos da linguagem, os quais observo com atenção e dos quais me sirvo para conhecer/reconhecer a vida social expressa e construída pela língua em uso.

A Deus, que nos presenteia com o potencial da linguagem e me propicia as condições para seguir em frente e aprender com ela, sobre ela, a partir dela. 


\title{
SUMÁRIO
}

\author{
Resumo
}

Abstract

Índice

Apresentação

Capítulo 1: A pesquisa e seus percursos

Capítulo 2: Uma análise discursiva de base pragmática

Capítulo 3: Trabalho e(m) discurso

Capítulo 4: A regulação jurídica do trabalho

Capítulo 5: Os caminhos da construção do sentido da voz do trabalhador

Capítulo 6: Considerações finais - perspectivas da prática discursiva jurídico-trabalhista

Bibliografia

Anexos 


\section{RESUMO}

A voz do trabalhador ocupa, ainda, um lugar secundário na interlocução capital x trabalho. Sua manifestação lingüística em instâncias de caráter oficial/institucional ocorre apenas nos momentos de maior tensão entre os interlocutores, em especial durante os processos trabalhistas, visando à validação/obtenção de um direito. Tal representatividade não se dá de forma direta, mas através da voz do advogado trabalhista, aqui chamado de locutoradvogado, porta-voz legitimado socialmente, que busca dirigir a argumentação no contrafluxo da voz predominante no universo do trabalho - a voz do capital.

Esta pesquisa tem por objetivo mostrar como a voz do trabalhador é representada no discurso jurídico trabalhista e quais os significados dessa representatividade no mundo do trabalho. O escopo teórico utilizado é fruto do diálogo interdisciplinar entre as teorias do texto e do discurso (em particular a semântica global e seu conceito de interdiscurso, e a semântica argumentativa, com seus conceitos de polifonia e direção argumentativa) e as disciplinas direito trabalhista e sociologia do trabalho.

A análise lingüístico-discursiva dar-se-á a partir de corpus composto por textos (orais e escritos) próprios a esse discurso e extraídos de um processo trabalhista típico. Os textos orais (não oficiais) produzidos no processo se constituem a origem discursiva dos textos escritos (oficiais e legais). Na transposição do oral para o escrito, a voz do trabalhador ganha estatuto diverso, porque passa a ser dirigida pela voz do locutor-advogado. Nesta pesquisa, verificar-se-á como nos textos escritos emergem, apagam-se ou permanecem de forma residual índices da voz do trabalhador.

A pesquisa pretenderá ainda mostrar como é possível ao pesquisador lingüista encontrar pistas lingüísticas de heterogeneidade em discursos pretensamente homogêneos, como é o discurso jurídico trabalhista, contribuindo com subsídios de sua especialidade para a construção de um quadro do que é, ou está se tornando, o mundo do trabalho nas sociedades ocidentais modernas, nas quais o Brasil se espelha.

PALAVRAS-CHAVE: análise do discurso, discurso jurídico trabalhista, discursos do trabalho, interdiscurso, polifonia. 


\begin{abstract}
The worker's voice still plays a secondary role in the interaction capital $\mathrm{x}$ labor. Its linguistic manifestation, of an official/institutional nature, occurs only in moments of maximum tension between interlocutors, particularly in judicial proceedings, in the area of labor relations, targeted at the authorization or obtention of a legal right. The worker's voice is not directly represented in such processes, but rather through a specialized lawyer's voice, herein named the locutor-lawyer, a socially sanctioned speaker, who addresses his or her arguments to a hegemonic voice in the discursive world of labor, namely the voice of capital.
\end{abstract}

This research explores the representation of the worker's voice in judicial proceedings discourse in the area of labor relations and deals with the question of the meanings attached to this kind of representation within the world of labor relations. The theoretical framework for this research is found in the interdisciplinary dialogue between theories of text and discourse (particularly global semantics with its concept of interdiscourse, and argumentative semantics with its concepts of polyphony and argumentative direction), as well as in the disciplines Law, in the area of Labor Relations, and the Sociology of Labor.

The linguistic-discursive analysis focusses on a corpus of oral and written texts within the domain of Legal Discourse in the area of Labor Relations and is taken from a typical judicial proceeding in this area. The (non-official) oral texts produced in the course of the judicial proceedings constitute the discursive source for the written texts (in this case, both official and legal documents). In the transposition from the oral to the written proceedings, the worker's voice acquires a different status, as it is now under the locutor-lawyer's supervision. This research explores the ways in which the worker's voice emerges, is deleted or leaves traces in the written texts that constitute the judicial proceedings.

Another aim of the research is to demonstrate how the linguist-researcher may find linguistic clues of heterogeneity in discourses (as the legal discourse in the area of labor relations) which are, at first sight, homogeneous. Thus, the linguist-researcher, drawing 
on linguistic-discursive tools, may contribute to an understading of how representations of labor relations in contemporary Western societies, including Brazil, are being shaped.

KEYWORDS: discourse analysis, judicial proceedings discourse in the area of labor relations, labor relations discourses, interdiscourse, polyphony. 


\section{ÍNDICE}

Apresentação 12

1. A pesquisa e seus percursos 19

$\begin{array}{ll}1.1 \text { Justificativa } & 19\end{array}$

$\begin{array}{ll}1.2 \text { O problema } & 21\end{array}$

$\begin{array}{ll}1.3 \text { Objetivos } & 22\end{array}$

1.4 Delimitação do objeto empírico 23

$\begin{array}{ll}1.5 \text { Metodologia / Etapas do trabalho } & 25\end{array}$

1.6 Algumas considerações sobre os pressupostos teóricos 27

2. Uma análise discursiva de base pragmática 31

$\begin{array}{ll}2.1 \text { Por uma semântica discursiva } & 31\end{array}$

2.1.1 Concepções de interdiscurso 33

2.1.2 Universo, campo e espaço discursivos / formação discursiva 38

2.1.3 Gêneros do discurso e cena enunciativa 41

$\begin{array}{ll}2.2 \text { O diálogo com a pragmática } & 61\end{array}$

2.2.1 Semântica global e pragmática $\quad 61$

2.2.2 Polifonia, interdiscurso, intertexto 75

2.2.3 Direção argumentativa: fenômeno de construção lingüística $\quad 78$ de direitos e deveres sociais

2.3 Retextualização, intertexto e interdiscurso $\quad 84$

2.4 Retextualização e direção argumentativa 85

2.5 Referenciação e construção do sentido $\quad 87$

2.6 Tempo, transform(ação) e sentido 93

3. Trabalho e(m) discurso 103

3.1 As transformações no mundo do trabalho: o discurso do trabalho como 103 bem desejável

3.2 A racionalidade econômica do novo capitalismo e o mundo do trabalho 110 no Brasil

3.3 O papel dos sindicatos $\quad 115$

4. A regulação jurídica do trabalho 124

4.1 A tradição do Direito: foco no passado 129

4.2 O direito de solidariedade $\quad 132$

4.3 O Direito Trabalhista no Brasil 136

4.4 Discurso jurídico / linguagem jurídica 144

4.5 Gêneros centrais do discurso jurídico trabalhista: petição, audiência, 146 entrevista inicial

5. Os caminhos da construção do sentido da voz do trabalhador 153

5.1 Da entrevista à petição: processos de retextualização e distribuição 156 das vozes discursivas

5.1.1 Análise da entrevista $\quad 161$

5.1.2 Análise da petição do ponto de vista dos processos de 166 retextualização

$\begin{array}{ll}\text { 5.1.3 A voz do trabalhador ganha corpo } & 178\end{array}$ 
5.2 Gênero entrevista: o sujeito discursivo trabalhador ganha voz

5.2.1 Efeito polifônico

5.2.2 Níveis de representatividade $\quad 182$

5.2.3 Interdiscursos 183

5.3 Gênero petição trabalhista: o sujeito discursivo trabalhador cede voz 184

5.3.1 Efeito monofonizante $\quad 184$

$\begin{array}{ll}\text { 5.3.2 Níveis de representatividade } & 187\end{array}$

5.3.3 Interdiscursos 188

5.4 A voz do trabalhador construída na petição: processos de referenciação 190 e recategorização do sujeito trabalhador

5.4.1 Referenciação na petição trabalhista: apagamento do sujeito 191 trabalhador?

5.4.2 Anáfora e polifonia: expressões nominais definidas na petição 193 trabalhista

5.5 A audiência trabalhista como prática discursiva triangular 202

5.5.1 Efeito monofonizante x efeito polifônico 209

5.5.2 Níveis de representatividade $\quad 214$

5.5.3 Interdiscursos 215

5.6 Retextualização, intertexto e interdiscurso: o diálogo entre Eu e Outro 217

5.7 A voz do trabalhador na cena enunciativa 220

5.7.1 Direção argumentativa geral 225

5.7.2 Recuos e avanços da direção argumentativa na petição 226 trabalhista

6. Considerações finais: perspectivas da prática discursiva jurídico-trabalhista $\quad 237$

Bibliografia 246

Anexos:

Anexo A - Transcrição parcial da entrevista advogado-trabalhador 255

Anexo B - Petição inicial para pedido de hora-extra (texto na íntegra) 274

Anexo C - Demais petições analisadas $\quad 281$

Anexo D - Modelos de formulários que constituem o processo trabalhista 291

Anexo E - Carta-convite ao escritório de advocacia trabalhista 304 


\section{APRESENTAÇÃO}

Uma vez alguém me disse que uma pesquisa científica não deveria nascer apenas de uma exigência acadêmica, mas deveria ser fruto de um tipo particular de angústia, uma espécie de dor de alma para a qual o melhor remédio seria o expurgo intelectual. Esta até então estranha relação entre coisas para mim tão díspares ficou gravada de tal forma em minha memória e exerceu tão grande influência na produção desta tese, que não posso deixar de mencioná-la nesta apresentação.

Há pouco mais de quatro anos identifiquei qual seria minha angústia particular que deveria transformar-se em produção intelectual para meu próprio alívio. Ao reconhecê-la, percebi que ela já estava lá há muito tempo, constituiu-se ainda naquela época em que eu, menina, não conseguia pegar no sono até que meu pai chegasse do trabalho. Lembro-me de que tinha muito medo de que ele não chegasse. Todos os dias ele pegava estrada para trabalhar. Ia num grupo de empregados em uma espécie de van, em que todos se alternavam na direção. A fábrica não era longe de São Paulo, onde sempre morei, mas a estrada era perigosa. Lembro-me de que ele trabalhava muito. Não havia tempo para mais nada. Quando em casa, estava em geral muito cansado para conversar conosco ou brincar. Nos fins de semana, queria que meu pai nos levasse a mim e minhas irmãs ao parque do Ibirapuera, o que nem sempre ocorria porque meu pai, em sua simplicidade, sem perceber que tê-lo inteiro conosco por várias horas era mais importante do que o parque em si, muitas vezes não nos levava, preferindo ficar em casa, vendo televisão e dormindo no sofá.

Italiano, imigrante, o trabalho foi sua vida, ou quase. Dele dependia não só seu sustento e o de sua família, como também a construção de uma nova identidade para si mesmo, agora que estava longe de seu país natal, de sua língua, de seus costumes. Casou-se com uma filha de italianos, minha mãe, que tinha em sua história uma relação com o trabalho muito parecida com a de meu pai. Meus avós, pais de minha mãe, enfrentaram o que meu pai enfrentou, construíram-se a si mesmos na nova terra e ensinaram a seus filhos o valor incomensurável do trabalho. O trabalho era o sentido da vida e indicava o único caminho para sua manutenção. 
Minha mãe era a contrapartida doméstica do trabalho incessante. Com hábitos europeus e com pouco dinheiro, ter em casa uma empregada para auxiliá-la sempre lhe pareceu um contra-senso. As filhas ajudavam na casa. As horas que minha mãe tinha para nós eram poucas e talvez por isso tenham se tornado inesquecíveis. Minha mãe nos contava muitas histórias, em especial as histórias da família. Histórias de luta e trabalho, de homens cruzando mares e de mulheres seguindo-os com vários filhos, ou não, e nesse caso assumindo para si sua criação e abraçando, invariavelmente, mais trabalho... Ouvia-a com total enlevo, chorando nos momentos mais tristes, rindo nos momentos alegres. Na maior parte do tempo, no entanto, minha mãe trabalhava na casa, inabalável, sem tempo para histórias. Havia um tempo para amar, sentir, viver e um tempo para trabalhar. Mas se narrar é curar, como diz Walter Benjamin, e se ouvir a narrativa é contá-la também, então, através das histórias de minha mãe, aqueles momentos juntas ganharam valor de eternidade, sem espaço para rupturas, e meu vínculo de amor com meus pais pôde manter-se intacto. Desde muito pequena, portanto, vivi a dicotomia trabalho-vida. Na narrativa podia viver intensamente o amor de meus pais, quando esta findava e o trabalho começava, devia contentar-me e esperar pelo próximo capítulo.

Assim cresci e logo vi-me também pronta para o trabalho, em suas diferentes modalidades: o trabalho doméstico, o trabalho escolar, depois o trabalho profissional (e remunerado), no qual centrarei meus esforços nesta tese, da perspectiva da analista do discurso que me tornei. Em condições bastante diferentes das condições de trabalho de meus pais (hoje o acesso à informação é outro, o que muda radicalmente a própria visão que se tem do trabalho realizado ou por realizar) e, diferentemente deles, tendo tido acesso ao ensino superior, pude viver a dicotomia trabalho-vida com crescente senso crítico, observando em mim mesma e no mundo ao meu alcance os mecanismos de reprodução e transformação dos discursos predominantes no mundo do trabalho profissional e, em particular, os mecanismos de representação/perpetuação/transformação de suas contradições e rupturas. Mas o que me interessa, sobretudo, é compreender como, nesses discursos, a voz do trabalhador é constituída, um trabalhador dividido e apartado, clivado desde dentro pela dicotomia trabalho-vida. 
Minha angústia particular, em síntese, que talvez seja compartilhada, de uma forma ou outra, por aqueles que se interessaram por estudar as relações trabalho e linguagem, pode ser resumida na dicotomia trabalho-vida instalada em mim mesma, desde cedo, incitando a busca por caminhos possíveis para sua superação. Hoje vejo que a angústia que habita meu universo pessoal era já conseqüência de um certo modo de compreender o trabalho e de realizá-lo, característico do século que findou, e que tem sua origem no século XIX e se estende até os dias atuais. Os caminhos para sua superação podem estar, em parte, na compreensão lingüístico-discursiva deste fenômeno, que é marcadamente social.

O que caracteriza o mundo do trabalho desde que o homem ocidental descobriu a "maisvalia” é sua formatação como instância exclusiva da economia. Para uma imensa maioria, o trabalho tem se distanciado das demais esferas essenciais para uma vida plena - a esfera política (em sentido amplo, que implica senso crítico em relação às dinâmicas de construção do trabalho e do sentido do trabalho) e as esferas cultural e espiritual. Alijado, supostamente autônomo, o trabalho adquire importância social crescente (refletida/construída em discurso) quanto mais se distancia das demais esferas. A complexidade desta situação passa despercebida pelas pessoas comuns, trabalhadores que criaram mecanismos de superação da dicotomia trabalho-vida com base na crença de que o trabalho, se bem remunerado, lhes possibilitaria apagar de suas vidas qualquer desconforto. O mecanismo central desta crença (ou ideologia naturalizada) é a luta pelo incremento do poder de compra: quanto maior o poder de compra, maior o sentimento de unidade e nãocontradição vivenciado pelo trabalhador.

Quando os benefícios materiais diminuem ou simplesmente deixam de existir, como em geral tem ocorrido nas economias de todo o mundo, a insatisfação aparece, e isto motivou e motiva a formação da organização sindical e de outras formas de organização que promovam as condições adequadas para a obtenção e manutenção de um trabalho e de suas garantias. O apagamento da dicotomia trabalho-vida através do contínuo provimento de benefícios materiais é, de fato, pelo que lutaram e ainda lutam sindicatos e organizações afins, que não enxergam condições para ou não se sentem capazes de extrapolar o dualismo 
e lutar verdadeiramente pela reintegração das esferas. Talvez esteja nesta dificuldade uma das origens do dito declínio do sindicalismo.

Outra forma de garantir os benefícios materiais das diferentes categorias de trabalhadores é o recurso à justiça do trabalho, sobre cujo discurso (o discurso jurídico trabalhista) nos debruçaremos neste estudo, de modo específico, já que foge ao escopo de uma tese explorar simultaneamente diferentes discursos produzidos no mundo trabalho.

O acesso à justiça do trabalho significa recorrer ao Estado como entidade intermediadora dos conflitos trabalhistas. O Estado, entendido como instância reguladora por excelência, é detentor das condições necessárias à manutenção do equilíbrio capital x trabalho, via legislação trabalhista, em um nível que se sobrepõe à esfera de atuação dos sindicatos. Além desta sobreposição de caráter legal/institucional, notamos uma diferença significativa (em geral despercebida) na forma de atuação da justiça do trabalho em relação ao sujeito trabalhador - se comparada à atuação da instância sindical - que a diferencia desta última junto ao mesmo trabalhador. Esta diferença está no fato de o sindicato representar uma categoria, e não um sujeito. Embora, tal qual os sindicatos, a justiça trabalhista restrinja-se a garantir benefícios materiais, é na justiça trabalhista que o trabalhador representa-se a si mesmo como sujeito de direito autônomo, o que por si significa aproximar os pólos da dicotomia trabalho-vida. Ao representar-se a si mesmo declarando-se EU, mesmo que de forma indireta (como veremos), o sujeito não separa dentro de si as esferas da vida. O sujeito fala como aquele que vive uma vida em comunidade, relaciona-se portanto em diferentes níveis com diferentes sujeitos e traz em si, inexoravelmente imbricadas, todas as esferas.

Observa-se que sua história pessoal, ou parte dela, deve ser de conhecimento do advogado trabalhista para efeito da redação da petição. Na audiência trabalhista, embora a formalidade do gênero tenda a apagar a autenticidade dos co-participantes (em especial do sujeito trabalhador, que não domina o discurso jurídico trabalhista e seus gêneros), o sujeito trabalhador está lá por inteiro, pois lá sua vida está em jogo em vários sentidos, e seus sentimentos se expressam diante do juiz, verbalmente ou não. 
O processo trabalhista de um sujeito dito "requerente", constituído por diferentes etapas que se materializam em gêneros do discurso, são a narrativa de uma parte da vida importante desse sujeito, são parte de sua história narrada ao juiz. É certo que esta narrativa faz-se de uma certa forma, com um certo objetivo, mas não deixa de ser uma narrativa que constrói-se a si mesma de forma viva, embora a superfície discursiva dos textos nuble tal vivacidade por efeito das restrições próprias aos gêneros que fazem parte do discurso jurídico trabalhista e através dos quais a voz de um determinado sujeito trabalhador se expressa.

Claro está que, por tratar-se de linguagem jurídica, e portanto altamente padronizada, os sujeitos ali representados adquirem uma homogeneidade aparente. Esta homogeneidade não descaracteriza o sujeito enquanto tal, apenas mostra quantos sujeitos tais quais o sujeito ali representado vivem vida similar e enfrentam agruras do mundo do trabalho parecidas o suficiente a ponto de poderem ser representadas com extrema semelhança na superfície discursiva. Mais do que descaracterizar a unidade e a singularidade da voz do trabalhador representada em um processo, a homogeneidade suscitada pela padronização da linguagem jurídica faz-nos ver quão gerais são as questões trabalhistas vivenciadas por milhares de brasileiros.

Estudar a esfera do trabalho pelas suas manifestações enquanto linguagem adquire, para esta pesquisadora, um duplo sentido:

$\checkmark$ um, mais evidente para os estudiosos em geral e para os lingüistas/analistas do discurso em particular, refere-se à compreensão de que o trabalho constitui-se também enquanto linguagem e portanto é passível de ser compreendido a partir dos discursos que constrói e faz perpetuar;

o outro, que está por trás do primeiro dando-lhe vivacidade, é a relação que se estabelece entre narrativa (ou linguagem) e trabalho, relação aprendida na infância e 
que ora assume o estatuto de uma instância que requer para si a (re)integração da esfera do trabalho.

Desta forma, se linguagem é vida e se o trabalho se constrói com, na e pela linguagem, caberia revivificar a linguagem do trabalho ou, especificamente neste estudo, a linguagem do discurso jurídico trabalhista, indagando-nos, talvez, em que pontos apresenta cristalização prejudicial à representatividade da voz do trabalhador, pontos tais que o desconecta de si mesmo. Caberia subverter tal linguagem liberando-a desses nós? Quais seriam as conseqüências para a prática do direito trabalhista? A resposta a tais questões foge ao que me proponho aqui, embora possa pincelar comentários a respeito aqui e ali. Em busca da re-conexão trabalho-vida, limito-me a procurar e descrever as pistas lingüísticodiscursivas que atestam um estado de coisas e tentar contribuir para a compreensão do mundo do trabalho com a parcela de conhecimento que me cabe como estudiosa da linguagem. Uma descrição nunca é suficiente, é certo, mas é um passo necessário para a visualização do quadro que se quer compreender. Neste caso, há um ponto central do quadro que nos interessa em particular: o sujeito trabalhador. É a partir dele que o quadro se desenhará e será a partir dele, como sujeito de direito que enuncia, que o quadro poderá se transformar. 
A PESQUISA E SEUS PERCURSOS 


\section{A PESQUISA E SEUS PERCURSOS}

\subsection{Justificativa}

Em trabalho anterior (Piccardi, 1999), procuramos demonstrar a importância de se averiguar lingüisticamente as formas pelas quais o discurso empresarial institucional garante a criação e perpetuação dos sentidos que lhe são convenientes. Foi possível, a partir de conceitos da pragmática, em especial da semântica argumentativa de Oswald Ducrot, apreender o jogo polifônico instalado nos textos analisados, em que um locutor - que representa a voz institucional - “orquestra” as demais vozes presentes (lembremos que não há discurso homogêneo), impondo uma certa direção argumentativa, em detrimento de outras direções, possíveis mas em dissonância com os interesses da empresa em questão.

No decorrer deste primeiro trabalho, constatamos o quão pouco as vozes menos representativas dos interesses da empresa se fazem presentes. A voz institucional ${ }^{1}$ - que se constrói buscando hegemonia - ocupa até mesmo os poucos espaços discursivos reservados à voz do trabalhador, como se pode observar durante a leitura atenta dos conhecidos jornais de empresa que, segundo o senso comum, seriam o canal de expressão dos trabalhadores nas empresas onde atuam.

Os jornais sindicais, por sua vez - em princípio o canal de expressão máximo da voz do trabalhador - têm mostrado um jogo polifônico muito próximo ao constatado nos textos empresariais institucionais. De fato, tais publicações, no atual momento sócio-histórico, não expressariam a voz do trabalhador, mas sim a voz da instituição Sindicato.

Emergem assim questões que nos motivam a desenvolver nova pesquisa, agora buscando entender o jogo discursivo na segunda ponta do binômio capital x trabalho: estaria a voz do

\footnotetext{
${ }^{1} \mathrm{O}$ termo institucional refere-se ao esforço desenvolvido por determinada instância de poder para promover seu nome, imagem e reputação. $\mathrm{O}$ ato institucional comunica sempre atributos favoráveis à organização. Os discursos institucionais, portanto, buscam construir uma imagem homogênea da mesma, isentando-a das contradições que poderiam prejudicar a promoção de atributos positivos. Quanto maior o poder de determinada instância, mais homogêneas e cristalizadas são suas práticas, que passam a ser chamadas de práticas institucionalizadas. No âmbito do sujeito trabalhador que atua no mundo do trabalho, o termo referese ao grau de inserção de seu discurso nas instâncias de poder, de modo a tornar tal sujeito capaz de, junto a tais instâncias, fazer valer interesses que não necessariamente coincidem com os interesses da organização onde atua. Esta inserção permite à voz do trabalhador adquirir estatuto oficial e legal no mundo do trabalho.
} 
trabalhador institucionalmente representada no mundo do trabalho? Se sim, onde e de que maneira? Em que discursos que permeiam o mundo do trabalho ela ecoaria e de que modo? É importante frisar que não temos a pretensão de responder tais questões, que deverão permanecer abertas, em discussão no capítulo final. Levantá-las agora significa apenas tornar mais evidente ao leitor as motivações para o presente trabalho.

A fim de podermos formular questões passíveis de serem respondidas nesta tese, é importante, antes de tudo, estabelecer um recorte preciso nesse vasto mundo do trabalho. Tal recorte implica não só selecionar um discurso - nesta tese, o discurso jurídico trabalhista - mas também apreender nesse discurso as relações interdiscursivas que o constituem e que interessam aos objetivos deste trabalho para, em conseqüência, escolher uma produção lingüístico-discursiva concreta. Assim, por uma decisão metodológica (a ser detalhada a seguir), frisamos que nos importarão neste estudo apenas os canais oficiais e/ou legais, ou seja, textos (e gêneros de textos) discursivamente reconhecidos como legítimos pelas partes envolvidas, a saber, tanto pelos representantes do capital como pelos representantes do trabalho (são os gêneros e textos oficiais); e textos (e gêneros de textos) com poder de fazer valer por força de lei a prática correlata à determinada produção discursiva (são os gêneros e textos não apenas oficiais, mas legais). Enfatize-se ainda que tais representantes deverão reconhecer-se mutuamente como legítimos ocupantes de seus postos. Trata-se de uma legitimidade que não depende do reconhecimento voluntário, mas de uma decisão social.

Assim sendo, algumas questões pertinentes e que poderão começar a ser respondidas através desta pesquisa são:

1. Como se dá a representatividade discursiva do sujeito trabalhador no discurso jurídico trabalhista, ou seja, como tal voz se constrói nos diferentes gêneros discursivos que compõem tal discurso, analisados via construções textuais concretas?

2. Seria tal representatividade homogênea ou expressa em diferentes níveis? Se heterogênea, como caracterizar tal heterogeneidade? Em outras palavras, a que interdiscursos remeteriam os diferentes níveis de representatividade levantados? 
3. Que sentidos são construídos através do jogo discursivo observado?

4. Os sentidos construídos nos permitem compreender melhor o mundo do trabalho?

5. Seria o discurso jurídico trabalhista uma instância discursiva de consolidação ou transformação do mundo do trabalho no Brasil?

\subsection{O problema}

A análise lingüístico-discursiva que se fará parte do pressuposto que a voz do trabalhador encontra representatividade discursiva oficial nos textos gerados em processos trabalhistas, cuja entrada está no que o Direito chama de petições trabalhistas. Tal representatividade permite ao trabalhador posicionar-se como indivíduo, possuidor de uma subjetividade (vide o uso das expressões “queixa” ou "reclamação” trabalhista), cuja voz se faz valer em um espaço discursivo fortemente institucionalizado, de onde emanam decisões com poder de alterar significativamente as práticas trabalhistas em geral e a vida de um determinado trabalhador em particular. Este tipo de representatividade parece não encontrar representatividade similar em outros discursos do mundo do trabalho. No entanto, esta representatividade não se dá de forma direta na petição trabalhista, mas articulada pelo que chamamos de locutor-advogado. Este imbui-se provisória e artificialmente da voz de seu representado, a quem atribui nos textos a terceira pessoa, o que se configura como aspecto fundamental para que se compreenda a natureza ambígua dessa representatividade. Além disto, observamos que tal representatividade não é homogênea no processo trabalhista como um todo: nos demais gêneros centrais que compõem o discurso jurídico trabalhista, a voz do trabalhador pode adquirir níveis diferentes de representatividade (caracterizada por maior ou menor grau de apagamento).

Embora, enquanto gênero, a petição trabalhista e demais textos orais/escritos que compõem o processo trabalhista sejam produto do discurso jurídico, do ponto de vista do jogo discursivo em que capital e trabalho buscam consolidar espaços, a petição e demais textos e gêneros de textos gerados no processo trabalhista, para efeito deste estudo, são também parte do conjunto de discursos que compõem o mundo do trabalho, pois é nele que se instala o conflito que dá origem à petição (documento central no processo trabalhista). 
Podemos dizer que, a fim de marcar um espaço oficial, a voz do trabalhador, por um viés de caráter pragmático, escapa pelo discurso jurídico trabalhista, onde encontra eco. Compreender de que forma se dá uma representatividade assim constituída, verificando o que ela significa enquanto prática discursiva é o problema que nos move.

\subsection{Objetivos}

O primeiro objetivo desta pesquisa é buscar a representatividade lingüístico-discursiva da voz do trabalhador no discurso jurídico trabalhista, considerado aqui parte integrante do conjunto de discursos que compõem o mundo do trabalho nas sociedades ocidentais modernas e local discursivo aparentemente preferencial de expressão oficial dessa voz.

Pretende-se averiguar como o processo jurídico trabalhista (cujo discurso se constrói através dos gêneros petição trabalhista - que formaliza o início de um processo trabalhista; entrevista inicial trabalhador-advogado - que gera a petição; formulários diversos - que marcam as etapas do processo; e audiência trabalhista) se articula como via importante de expressão oficial da voz do trabalhador nas relações formais empregado x empregador. Daí ser necessário entender como se dá esta representatividade na superfície discursiva dos textos produzidos em um processo trabalhista típico ${ }^{2}$ : o que a motiva, o que a coage, o que a suprime, e quais estratégias são utilizadas para fazer ecoar, ou não, tal voz. Nesse caminhar, será preciso, portanto, além de buscar tal representatividade na petição trabalhista (considerado gênero central no discurso jurídico trabalhista, porque marca a abertura do processo trabalhista), também averiguá-la nos gêneros entrevista inicial e audiência: o primeiro, gênero oral a partir do qual é redigida a petição (gênero escrito central no processo); o segundo, gênero oral (embora apenas os registros escritos gerados em audiência tenham valor legal), através do qual se delibera a validade do julgado.

O alcance de tal objetivo dar-se-á com base no escopo teórico fruto do diálogo interdisciplinar entre as áreas do vasto campo que compreende as teorias do texto e do discurso, para as quais língua significa atividade de um sujeito falante inserido em um contexto sócio-histórico, em particular a semântica global, a semântica argumentativa e

\footnotetext{
${ }^{2}$ Ver definição adiante.
} 
uma lingüística textual de caráter discursivo, e destas disciplinas com o direito, direito trabalhista e sociologia do trabalho. Observe-se que tais campos teóricos podem parecer distantes entre si, se não antagônicos, dependendo da perspectiva que se adota. Move-nos, no entanto, a perspectiva interdiscursiva, segundo a qual tais áreas dialogam em aspectos produtivos para o desenvolvimento desta análise. Esta interdiscursividade será devidamente explicitada em capítulo do trabalho.

O segundo objetivo, conseqüência do primeiro, refere-se à intenção de contribuir para enriquecer os métodos de abordagem textual à luz dos pressupostos teóricos das teorias acima apontadas, tendo como foco a questão da construção do sentido no texto jurídico trabalhista e sua relação com os sentidos produzidos no mundo do trabalho.

Finalmente, como terceiro objetivo, este estudo pretende mostrar como um lingüista amparado em uma perspectiva discursivo-pragmática de linguagem pode contribuir com seu conhecimento específico para esboçar um quadro do que é, ou está se tornando, o mundo do trabalho nas sociedades ocidentais modernas.

\subsection{Delimitação do objeto empírico}

Conforme apontado acima, os textos mais significativos gerados em um processo trabalhista serão o material lingüístico sobre o qual nos debruçaremos. Tal material foi extraído do acompanhamento de um processo trabalhista "típico"3 (de acordo com os advogados especialistas nesse ramo do direito convidados a colaborar na pesquisa). Observe-se que, da perspectiva do Direito, os textos legais são apenas os textos escritos. A petição trabalhista, documento central do processo, origina-se, no entanto, de uma primeira interlocução oral entre trabalhador e advogado trabalhista, gênero ao qual chamamos de entrevista inicial trabalhador-advogado, que não tem valor legal. A audiência, por sua vez, embora constitua-se como gênero oral, é registrada por escrito e são estes registros que têm valor legal. Os gêneros orais do processo trabalhista são, assim, a origem discursiva dos gêneros escritos, estes sim com valor legal. As diferenças (mais ou menos evidentes,

\footnotetext{
${ }^{3}$ Um processo é considerado típico por tratar de matéria comum a muitos processos trabalhistas, por possuir abordagem igualmente comum e por receber tratamento similar pelo juiz. Isto significa que seu percurso se dá dentro do que é mais corriqueiro no direito trabalhista, o que dá ao processo um nível de abrangência que nos permite generalizar as conclusões tiradas de sua análise.
} 
dependendo do gênero analisado) entre um texto oral e o respectivo texto escrito revelam diferentes níveis de representatividade da voz do trabalhador durante o processo trabalhista, que encontram significado quando observados no contexto amplo do mundo do trabalho. Em nossa pesquisa verificar-se-á como nos textos escritos emergem, apagam-se ou permanecem de forma residual os índices dessa voz.

A voz do trabalhador no mundo do trabalho, claro está, não está circunscrita aos textos gerados no processo trabalhista. Como destacamos anteriormente, a opção por este corpus deve-se às exigências levantadas pela pressuposição mencionada nos objetivos da tese: a de que o discurso jurídico trabalhista seria o local privilegiado para a expressão formal (institucional, oficial e legal) da voz do trabalhador. Assim sendo, muitos textos e gêneros de textos orais/escritos que compõem o universo do trabalho não farão parte desta pesquisa. Tais textos e/ou gêneros de textos são, principalmente:

a) Textos produzidos no interior das empresas, organizações ou instituições que abrigam o trabalhador no exercício de suas funções: os textos de caráter oficial produzidos pelo empregado no exercício de suas funções, e que são por ele assinados, são a materialização da voz hegemônica da organização, não atestando, portanto, em princípio, a subjetividade do enunciador. Tanto é que no universo das empresas e organizações afins pouco importa quem assina os textos de caráter oficial, desde que possua o cargo exigido na hierarquia da empresa. Isto equivale a dizer que, nesses casos, a assinatura atesta uma autoridade impessoal e, portanto, relativa à organização. Por outro lado, os textos cujas assinaturas atestam de fato uma autoria não possuem a autoridade necessária para que gerem as ações empresariais que fazem a organização caminhar.

No primeiro caso se encontram todos os textos para os quais (e não por acaso) existem cursos de redação, e cujos gêneros se cristalizaram no dia-a-dia empresarial: carta/ofício, memorando, circular, ata, relatório, manuais de normas e procedimentos, jornal de empresa e todos os formulários pré-impressos, para citar os mais relevantes. No segundo caso, encontram-se textos diversos, cujos gêneros são fracamente institucionalizados, e que são a via de escape das vozes individuais, englobadas no que genericamente se pode chamar de a voz do trabalhador. São eles: bilhetes, escritas em portas e paredes de banheiro, alguns 
tipos de $e$-mails e grande parte dos textos orais, tais como as conversas entre colegas, falas em assembléias, reuniões, etc.

Os do primeiro grupo evidenciam logo à primeira vista a forte efeito de homogeneidade da voz institucional, representativa do capital, daí sua exclusão do corpus. Os do segundo grupo não se constituem enquanto gêneros oficiais/legais no universo em questão, capazes de motivar ações no âmbito de atuação da empresa como um todo. Seu efeito perlocutório, para lembrar os ensinamentos de Austin, não ultrapassa de imediato o âmbito da organização em si, pouco interferindo na atuação da empresa como organismo social e que, portanto, interage com o que está fora de suas quatro paredes. Em alguns casos, tal efeito provocará transformações nos discursos dominantes, mas apenas no longo prazo. Por não constituírem gêneros validados entre as partes, a fim de que deles se originem as ações que mobilizam o dia-a-dia da empresa e consolidam sua perpetuação, também foram excluídos do corpus.

b) Textos produzidos nas instâncias sindicais: está pressuposto nesta pesquisa que os jornais dos sindicatos não representam hoje, de fato, a voz do trabalhador. Por outro lado, da mesma forma que nas empresas, os textos produzidos internamente nos sindicatos e que mobilizam as ações de perpetuação da entidade são fortemente institucionalizados, o que igualmente justifica sua exclusão.

\subsection{Metodologia / Etapas do trabalho}

A metodologia para análise adotada segue as tendências atuais em análise do discurso, que considera o primado do interdiscurso. Como diz Mussalin (2001):

As recentes pesquisas afirmam o primado do interdiscurso sobre o discurso, diferentemente da AD-1, que concebe a relação entre os discursos como sendo uma relação entre "máquinas" discursivas justapostas, cada uma delas autônoma e fechada sobre si mesma; e diferentemente também da AD-2, que considera a existência de FDs constituídas independentemente umas das outras para depois serem postas em relação.

Assim é que não se escolheu uma seqüência discursiva fechada em um único texto, mas sim gêneros e textos em relação em uma seqüência discursiva ampla, que corresponde a uma prática discursiva em curso (um processo trabalhista). Da mesma forma, a análise 
lingüística desta seqüência não se faz de modo a considerar construções sintáticas e léxico isoladamente para depois se estabelecerem relações entre o nível lingüístico e o discursivo. A análise discursiva da seqüência em pauta não separa lingüístico e discursivo. Além disso, procura-se tratar toda a seqüência como constitutivamente interdiscursiva, daí a remissão constante ao conjunto de gêneros e textos do processo trabalhista escolhido e às suas condições de produção.

Importa ainda salientar a importância da perspectiva de linguagem de Ducrot (1987) em nosso trabalho, para quem sintaxe e léxico não simplesmente remetem a discursos ou os representam, mas em si mesmos os constituem, viabilizando com seu conceito de polifonia uma tal integração língua e discurso que nos permite analisar as seqüências em foco tendo em vista a simultaneidade do fenômeno linguagem, que é língua e discurso em integração.

Com isto em vista, procedeu-se às seguintes etapas para consolidação deste trabalho:

a) Desenvolvimento dos pressupostos teóricos descritos no capítulo 2, através de pesquisa bibliográfica, leitura e fichamento de obras referenciadas e construção das interfaces teórico-metodológicas.

b) Levantamento bibliográfico de autores especializados em direito do trabalho e em sociologia do trabalho, e desenvolvimento de uma base conceitual nessas áreas da atividade humana (uma vez que os discursos envolvidos nelas se articulam), a fim de melhor delinearmos o contexto sócio-histórico da pesquisa e as condições de produção do discurso jurídico trabalhista .

c) Acompanhamento "in loco" de um processo trabalhista típico, junto a escritório de advocacia trabalhista convidado a participar da pesquisa, com levantamento e/ou registro dos textos produzidos.

d) Análise da produção textual central gerada no processo trabalhista em pauta para verificação das estratégias de representação da voz do trabalhador.

e) Estabelecimento de relações entre o resultado da análise lingüístico-discursiva e as teorias de apoio das áreas afins, procurando-se finalmente caracterizar, sob a forma de 
considerações finais, o contexto geral do mundo do trabalho no Brasil, do ponto de vista do pesquisador lingüista-analista do discurso.

1.6 Algumas considerações sobre os pressupostos teóricos

Guia-nos uma análise lingüístico-discursiva, como se verá a seguir, que, além de corresponder à fase mais atual da Análise do Discurso (AD) francesa, corresponde a um fazer científico na área das humanas que começa a reintegrar aspectos pouco considerados nas décadas de 60 e 70.

Compreendemos, de acordo com Eagleton (2003), que o fazer científico das ciências humanas nessas décadas (que o autor chama de teoria da cultura, abrangendo especialmente as ciências sociais, a ciência política, a antropologia, a história, a semiótica, a análise do discurso de linha francesa) desenvolveu-se de maneira tal a contribuir fortemente para esclarecer a importância de se considerar o diferente, o heterogêneo, como alvo de pesquisas. Assim, a teoria da cultura contribuiu para legitimar objetos de estudo tais como gênero e sexualidade, corpo e prazer, cultura popular, ecologia e poder, temas até então desprezados. Para tal, sob forte influência do marxismo (seja alinhando-se a ele, seja confrontando-o), a teoria da cultura precisou desestabilizar conceitos como norma, autoridade, maioria, unidade, consenso, sujeito, que passaram a ser compreendidos pejorativamente como universais abstratos, categorias insuficientes e ultrapassadas.

No entanto, a valorização da diferença e do heterogêneo, explorada nessas décadas pela teoria da cultura sob a forma de produção intelectual variada, efervescência universitária (que apartou qualquer outro tipo de enfoque acadêmico) e intensa luta política em prol das esquerdas, não foi suficiente para promover a dignidade dos cidadãos em escala mundial. O grande escândalo que paralisou e ainda paralisa humanistas alinhados à teoria da cultura é o de que a grande maioria da população mundial está sendo banida para as margens... O que fazer quando o heterogêneo se torna "homogêneo"? 
A desesperança vence o escândalo na década de 90, quando se instala uma ruptura importante na teoria da cultura: segundo Eagleton (2003), autores como Richard Rorty e Stanley Fish nos Estados Unidos, rotulando-se anti-teóricos da cultura, propuseram que a cultura (ora cultuada como elemento de base, no lugar de Deus ou da Natureza) fosse vista como não fundada na razão. Uma cultura, segundo eles, justifica-se por si mesma. Temos aqui o pós-modernismo decretando a impossibilidade intelectual de refletir sobre a cultura. Esta postura não é apenas catastrófica para as ciências humanas, como o é politicamente. Tem-se nela o fundamento para idéias como a de que a globalização é inevitável; ou de que (para nos aproximarmos do foco desta tese) o incremento do poder de compra através do trabalho remunerado é tudo que se pode esperar do trabalho; ou ainda de que o mundo se reduz à linguagem e de que estamos inevitavelmente atados aos discursos que produzimos... Pode-se argumentar que animais não lingüísticos ajam com base em uma espécie de razão, mas só o homem, como animal lingüístico, pode ser moral, perguntandose a si mesmo se determinada razão é boa ou não. Ao estudioso cabe mais do que nunca perguntar-se: isto que faço, a disciplina que ajudo a construir, é boa o suficiente? Traz o que a humanidade precisa hoje? E é a este aspecto que o lingüista-analista do discurso não pode mais se furtar. Como afirma Eagleton na mesma obra: "knowledge and morality, then, are not finally separable, as the modern age tends to assume”4.

Se a teoria da cultura, fruto do modernismo e mais especificamente do estruturalismo, errou por considerar não haver uma realidade além dos microcosmos estudados e por constituirse de tal maneira teórica a ponto de reduzir o mundo a discursos, a anti-teoria da cultura pós-moderna errou ao considerar que não se pode ter informação sobre o mundo, já que o mundo seria ele mesmo informação. De um lado, desconexão entre teoria e prática; de outro, seu amalgamento. Nos dois casos, paralisia para a ação, intelectual e prática. A teoria da cultura continua a criticar a universalidade como abstração idealista, enquanto corporações transnacionais cada vez mais fortes enraízam-se em todo o mundo; a antiteoria da cultura, por sua vez, omite-se quanto às críticas ao universal e reduz a ocupação das corporações transnacionais a uma questão de estilo de vida... Tal estado de coisas mostra que o impasse está instalado.

\footnotetext{
${ }^{4}$ Conhecimento e moralidade, então, não são finalmente separáveis, como a era moderna tende a assumir.
} 
Se num certo período foi necessário pôr muita coisa de lado para legitimar uma maneira de fazer ciências humanas e elevar o estatuto de determinados objetos de estudo, a superação do impasse exige revisitar o recorte e ampliá-lo. Cabe perguntar: as razões da teoria da cultura são boas, ou antes, quais são elas, qual racionalidade, enfim, guia seus estudos e a que isto tem levado? Ou correr o risco de as disciplinas mais representativas da teoria da cultura tornarem-se irrelevantes, como a própria análise do discurso. Esta tese, construída no escopo da análise do discurso de linha francesa em diálogo com a pragmática, tem a pretensão de, em certa medida, e de acordo com objetivos modestos e bem focados, desenvolver-se na direção da superação do impasse. Como afirma Eagleton (2003):

Cultural theory as we have it promises to grapple with some fundamental problems, but on the whole fails to deliver. It has been shamefaced about morality and metaphysics, embarrassed about love, biology, religion and revolution, largely silent about essences, universals and foundations, and superficial about truth, objectivity and desinterestedness. This, on any estimate, is rather a large slice of human existence to fall down on. It is also, as we have suggested before, rather an awkward moment in history to find oneself with little or nothing to say about such fundamental questions ${ }^{5}$.

Evidentemente, não é possível nem seria nossa intenção tornar esta tese veículo para discussões tão abrangentes. O que fazemos em prol dessa abrangência é propor um escopo teórico mais elástico ao combinarmos análise do discurso e pragmática e trabalhar sobre o corpus de forma mais dinâmica. Acreditamos que tal abrangência se faz necessária pelo fato de ajudar a ampliar horizontes em busca de respostas que sejam satisfatórias não apenas para o cumprimento de uma exigência acadêmica e para o incremento das discussões dentro da lingüística, mas também para ajudar a construir novos referenciais para a resolução de problemas fora de nossa área específica de atuação, interdiscursivamente.

\footnotetext{
${ }^{5}$ A teoria da cultura que conhecemos promete o embate com problemas fundamentais, mas no geral falha em seus resultados. Tem sido tímida sobre moralidade e metafísica, constrangida sobre amor, biologia, religião e revolução, largamente silenciosa sobre o mal, reticente sobre morte e sofrimento, dogmática sobre essências, universais e fundamentos, e superficial sobre verdade, objetividade e imparcialidade. Isto, em qualquer estimativa, é ser mal sucedido em uma grande fatia da existência humana. É também, como sugerimos antes, um momento particularmente difícil da história para nos encontrarmos com pouco ou nada a dizer sobre tais questões fundamentais.
} 
UMA ANÁLISE DISCURSIVA DE BASE PRAGMÁTICA 


\section{UMA ANÁLISE DISCURSIVA DE BASE PRAGMÁTICA}

\subsection{Por uma semântica discursiva}

A prática da análise lingüístico-discursiva que tem sido empreendida desde o mestrado (com o objetivo de delinear e compreender mais a fundo a produção de sentido nos discursos selecionados) tem revelado quão necessário é ter-se como base teórica conhecimentos sobre língua e linguagem suficientemente abrangentes para fundamentar adequadamente tais análises.

A opção por aprofundar aspectos pontuais a partir de uma teoria (ou diferentes teorias complementares), ou a opção por explorar diferentes aspectos de um corpus a partir de uma única teoria, se por um lado representam opções que poupam ao pesquisador o esforço intelectual de buscar interfaces teóricas e metodológicas nem sempre evidentes, por outro podem levar a reducionismos e/ou a aplicações mecânicas em prejuízo da melhor compreensão dos sentidos produzidos, tendo em vista os objetivos da análise.

Se a língua é viva, cumpre trazê-la inteira à análise, representada em um corpus vivo, do qual só poderá dar conta uma teoria igualmente viva e capaz de incorporar aos seus preceitos toda a dinâmica que evidentemente subjaz a tudo o que é vivo.

A semântica global proposta por Maingueneau (1984) apresenta-se neste trabalho como teoria global e central justamente por ser capaz de integrar, em especial sob a luz de seu conceito de interdiscursividade, abordagens pontuais da análise ora empreendida.

Como se verá adiante, para Maingueneau o conceito de interdiscurso é prioritário ao conceito de discurso, uma vez que, para o autor, a interdiscursividade é constitutiva da linguagem. Desta forma, e de acordo com tal conceito de interdiscurso, que preconiza que EU e OUTRO se constituem juntos, aspectos teóricos que podem ser considerados por alguns como não dialógicos passam a estabelecer sadia e produtiva conversação. É o caso do conceito de retextualização, aqui utilizado conforme o define Marcuschi (2001). Visto da perspectiva estrita da lingüística textual, o conceito é útil para a análise essencialmente lingüística. No entanto, visto do ponto de vista da semântica global, o conceito de 
retextualização passa a configurar-se como um nível específico de interdiscursividade, ampliando o potencial esclarecedor da análise.

Neste capítulo, procuraremos mostrar como se articulam alguns desses conceitos. Esclareceremos a natureza do diálogo entre o conceito de interdiscursividade de Maingueneau (1984) e os conceitos de direção (ou orientação) argumentativa e polifonia (conforme Ducrot: 1977, 1981, 1987) utilizados na análise. Esclareceremos também as relações que estabelecemos entre interdiscursividade e os conceitos de retextualização (já mencionado) e referência (conforme Marcuschi: 2000), igualmente utilizados. A nosso ver, todo o suporte teórico de caráter, ao menos em princípio, mais lingüístico (como as contribuições de Ducrot e Marcuschi, para os quais o intradiscurso é o objeto) é importante para construir a análise discursiva. Por outro lado, não se pode observar adequadamente os fenômenos lingüísticos sem uma teoria do discurso abrangente que direcione a análise. Interdiscurso e intradiscurso se articulam para produzir sentido. Conforme afirma Courtine (1981):

L’interdiscours d'une séquence discursive apparaît ainsi comme le lieu où se realize la séquentialisation des elements du savoir, où la dénivellation interdiscursive des [E] est linéarisée, mise à plat en une surface unique de [e] articulées. (p. 50) ${ }^{6}$

Ou, mais adiante:

[...] nous ne nous autoriserons à parler de discours qu'au terme de l'articulation du plan de l'interdiscours et de celui de l'intradiscours. (p. 51) ${ }^{7}$

Por trás da perspectiva discursiva, ainda, deve estar, a nosso ver, uma perspectiva pragmática, alinhavando os esforços discursivos no nível abrangente da comunicação humana.

Por esta razão, preferimos usar o pronome pessoal EU para identificar o sujeito do discurso (como é usual na pragmática), em lugar do substantivo MESMO (como é mais comum na análise do discurso francesa, ou AD). A nosso ver, EU remete a um sujeito menos

${ }^{6}$ O interdiscurso de uma seqüência discursiva aparece assim como o local em que se realiza a seqüencialização dos elementos do saber, em que o desnivelamento interdiscursivo dos enunciados é linearizado, estratificado em uma superfície única de enunciados articulados.

${ }^{7}$ [...] nós nos permitimos falar de discurso senão em termos da articulação do plano do interdiscurso e do intradiscurso. 
assujeitado, capaz de e levado a assumir seu papel de sujeito social em discurso. O substantivo MESMO é carregado dos sentidos da repetição, da não transformação e da inação, sentidos estes que correspondem apenas parcialmente aos sentidos apreendidos através da observação da prática discursiva.

\subsubsection{Concepções de interdiscurso}

Realizar esta tese sem levar em conta a noção de interdiscurso, em suas diferentes concepções, seria ignorar a própria noção do Outro no plano discursivo, o que levaria, em última análise, à realização de um trabalho completamente diferente, talvez mais pobre em relação à multiplicidade de conclusões preliminares que a aplicação da noção permite. De fato, a noção de interdiscurso que utilizaremos é a base da análise lingüístico-discursiva que pretendemos empreender.

Ocorre que, assim como em grande parte das noções que as disciplinas do discurso utilizam, e coerentemente com o seu postulado em relação ao Outro no discurso (um Outro não homogêneo e atravessado por diferentes Outros), a noção de interdiscurso não é uniforme e é descrita e utilizada de maneiras mais ou menos diferentes pelos autores. Assim cabe, antes de mais nada, precisar qual a noção de interdiscurso aqui privilegiada, e preconizada por Maingueneau (1984).

Possenti (2002), em um dos capítulos do livro, ao recorrer à noção de interdiscurso aqui proposta, faz breve síntese do que exploram as diferentes noções em voga, que vale a pena transcrever:

As noções mais correntes de interdiscurso exploram basicamente: a) os múltiplos sentidos de um mesmo texto - o que remete à idéia de que há mais de um discurso onde se poderia imaginar que há um só (o que estabelece um paralelo sólido com a noção de polifonia); b) a presença de um discurso no outro, que decorre de uma vizinhança relevante entre dois (ou mais) discursos, do que resulta que elementos do Outro (discurso) estejam no discurso sob variadas formas sintático-semânticas (nominalizações, negações, topicalizações etc.), que se resumem, praticamente, em termos discursivos, ao pré-construído (para estas questões ver, especialmente, Henry (1975), Pêcheux (1975), Courtine (1982), Pessoa de Barros e Fiorin (1994)). (p. 195) 
Para inserir a noção que nos interessa, aponta que, mais adiante:

... ao lado dessas concepções mais conhecidas, uma outra, menos familiar, mas, penso, de relevância inversamente proporcional a sua familiaridade, merece destaque: a noção de interdiscurso proposta por Maingueneau.

E é justamente tal noção, explicitada em Maingueneau (1984), que procuraremos definir, ao mesmo tempo em que tentaremos deixar clara sua relevância para este trabalho. Salientamos que esta noção não se contrapõe necessariamente às noções brevemente expostas acima. Dependendo do objetivo da análise que se pretende empreender, da metodologia adotada e do corpus considerado, estas últimas podem ser operadas a partir da primeira. Salientamos ainda que as diferentes noções de interdiscurso provêm do dialogismo postulado por Bakhtin, que representa, antes de tudo, uma opção filosófica fundamental na maneira de se compreender a linguagem.

A interdiscursividade, conforme a compreende Maingueneau, postula ser o interdiscurso anterior ao discurso. O que isto significa? Significa que a interdiscursividade se inscreve na perspectiva de uma heterogeneidade constitutiva da linguagem, segundo a qual há uma relação indissolúvel entre o EU e o OUTRO. Não existe discurso que não esteja sempre-já afetado por esta heterogeneidade, por mais que, em muitos casos, a materialização de tais discursos (ou seja, os textos que os veiculam) se dê de tal forma a obscurecer com bastante eficiência esta heterogeneidade, criando efeitos de sentido que a mascaram.

Assim, ao definir interdiscurso como anterior ao discurso, Maingueneau prioriza a simultaneidade sócio-histórica desse EU X OUTRO, privilegiando, no que toca à análise concreta dos enunciados, o espaço discursivo em que tais vozes se constituem. Ou, como ele afirma, a unidade de análise pertinente deixa de ser o discurso, mas um espaço de troca entre vários discursos convenientemente escolhidos. Brandão (1991) interpreta de duas maneiras tal afirmação:

1. o estudo da especificidade de um discurso se faz colocando-o em relação com outros discursos;

2. o interdiscurso passa a ser o espaço de regularidade pertinente, do qual os diversos discursos não seriam senão componentes. Esses discursos teriam a sua identidade estruturada a partir da relação interdiscursiva e não 
independentemente uns dos outros para depois serem colocados em relação. (p. 72)

A primeira interpretação nos leva diretamente à questão da metodologia adotada para a composição de um corpus significativo e às limitações a que as considerações finais se submetem sem o necessário estabelecimento das relações (inter)discursivas. A segunda nos remete à importância do conceito de espaço discursivo como local de regularidades (como veremos adiante), espaço este obrigatoriamente construído pelo pesquisador a partir de certa metodologia.

Maingueneau aprofunda sua definição alegando que reconhecer o primado do interdiscurso é construir um sistema através do qual a definição de uma rede semântica circunscrita na especificidade de um discurso coincide com a definição das relações desse discurso com seu OUTRO $^{8}$. Segundo ele, no espaço discursivo, o OUTRO não é um fragmento localizado, uma citação, nem uma entidade exterior, não é também necessário que ele seja percebido por alguma ruptura visível no discurso. O OUTRO é encontrado na raiz de um EU sempre e já descentrado pela relação com ele mesmo. O OUTRO é aquela parte do sentido que o discurso sacrifica para constituir sua identidade. O conflito regrado entre um EU e seu OUTRO indissociável (verso e reverso) é a condição de existência de uma formação discursiva.

Vale lembrar o que diz Brandão (1991) a respeito do conceito de formação discursiva (ou FD), citando Courtine:

Assim, uma FD não deve ser entendida como um bloco compacto e coeso que se opõe a outras FDs. Pois "uma FD é heterogênea a ela própria” e o seu fechamento é bastante instável, não há um limite rigoroso que separa o seu "interior" do seu "exterior" uma vez que ela confina com várias outras FDs e as fronteiras entre elas se deslocam conforme os embates da luta ideológica. É assim que se pode afirmar

\footnotetext{
${ }^{8}$ Nesse sentido, não se pode falar de uma análise lingüística ou discursiva, mas tão somente de análises lingüístico-discursivas. Como diz Courtine (1981: 41): “... l'étude de l'intradiscours qu'une telle séquence manifeste est indissociable de la prise en compte de l'intrerdiscours de la FD” (em português: o estudo do intradiscurso que uma tal seqüencia manifesta é indissociável da consideração do interdiscurso da FD).
} 
que uma FD é atravessada por várias FDs e, conseqüentemente, que toda FD é definida a partir de seu interdiscurso. (p. 72)

A partir da definição de interdiscurso aqui descrita, vemos que a própria noção de discurso é afetada. Trata-se de entender discurso menos como um conjunto de enunciados apreensíveis alinhados (ou seja, formações discursivas) em campos discursivos que se distinguem e se contrapõem, e mais como o próprio conjunto de regras de restrições que delineiam a constituição de tais discursos. Tais regras, as quais Maingueneau chama de sistema de restrições de boa formação semântica, são o que virtualmente alinha os discursos. Nesse alinhamento, EU X OUTRO se constituem ao mesmo tempo. A hipótese de um discurso que é afetado por outras vozes após sua constituição torna-se sem sentido na perspectiva que adotamos. Não se trata de um OUTRO que "invade” o discurso do EU, ou de um EU que “incorpora” elementos discursivos produzidos exteriormente, mas de um EU X OUTRO constituídos juntos e ao mesmo tempo, de modo a um não existir sem o outro.

Segundo Maingueneau (1984), pode-se considerar que, cronologicamente, é o discurso dito segundo que se constitui através do discurso primeiro. Parece lógico pensar que o discurso primeiro é o OUTRO do discurso segundo e que o inverso não é possível. No entanto, alguns aspectos mostram que esta lógica é falha:

1. Inicialmente porque o discurso primeiro não permite a constituição de discursos segundos que o ameacem em seus fundamentos, então o discurso primeiro se apropria do que deverá se tornar um discurso concorrente e o apreende como uma figura privilegiada do seu OUTRO. O discurso segundo nasce no interior do espaço discursivo anterior sem constituir-se uma oposição perfeita a ele; o discurso segundo já nasce mesclado de outras formações discursivas.

2. A assimetria ligada à ordem da gênese não recobre, assim, a totalidade de relações entre discursos primeiro e segundo. 
O discurso segundo pode perder a ligação com seu discurso primeiro, mas não necessariamente com as estruturas semânticas correspondentes, pelas quais continuará a ler a figura do OUTRO, até que a dependência semântica de um enunciado não coincida mais com aquela que reivindica seu autor.

O que se coloca é que um discurso segundo é derivado regularmente de um ou vários outros campos discursivos, e de uma ou várias FDs, e que cabe à semântica discursiva simplesmente mostrar a quais restrições tal derivação se submete e em que condições o “novo” é possível.

Podemos dizer que o discurso jurídico trabalhista é discurso segundo em relação ao discurso jurídico. Embora em sua formação exigisse para si uma nova configuração para alguns conceitos essenciais, esta “inovação”, digamos assim, ocorreu e ocorre de forma a acomodar-se aos pressupostos conceituais do Direito, cujos campos e formações discursivas tradicionais apreendem o novo discurso como seu e o condicionam. O discurso segundo, como foi dito, nasce assim incorporado ao discurso primeiro, que, no caso do discurso jurídico, mais do que tomar para si o discurso jurídico trabalhista como figura privilegiada, autoriza sua existência.

Além disso, o discurso jurídico trabalhista já nasce fortemente marcado pelos discursos que constituem o mundo do trabalho, em especial o discurso sindicalista e o discurso empresarial. Tais discursos são de fato os Outros constitutivos do discurso jurídico trabalhista.

A definição de interdiscurso de Maingueneau sustenta uma relação dupla com a descontinuidade, que consiste em suscitar certas linhas de ruptura, eliminando outras. A descontinuidade suscita as rupturas instituindo zonas de regularidade que tratam de processar a continuidade da história das idéias tradicionais. Assim é que, desde sua constituição, o discurso jurídico trabalhista perpetua as noções mais essenciais ao Direito, configurando, em função da presença dos Outros a que nos referimos anteriormente, um espaço discursivo polêmico. 
Esta mesma definição de interdiscurso (apoiada neste ponto por Foucault) vai contra o vício estruturalista de propor sistemas contínuos e unitários, que suprimem a categoria “acontecimento". A noção de interdiscurso pressupõe a categoria “acontecimento”. E a noção de movimento implícita na categoria é própria aos discursos, que se inscrevem no prolongamento de duas correntes para se manterem flexíveis: uma que caminha para um processo de difusão progressiva, e outra que restringe historicamente o processo. $\mathrm{O}$ discurso jurídico trabalhista, entendido como primordialmente interdiscursivo, sustenta-se nessa tensão: de um lado, as vozes de Outros que o ligam às tradições do Direito, restringindo o processo de abertura; de outro lado, as vozes de Outros que o lançam para demais campos e formações discursivas, em um dialogismo vivo, polêmico e progressivo, que acarreta as mudanças próprias aos discursos. Assim, qualquer análise discursiva deverá acatar para si o grande desafio de manter-se flexível e dinâmica, compreendendo que a categoria “acontecimento” (ou ação, movimento) deve lhe ser inerente.

É a partir desta visão dinâmica que estabelecemos o diálogo entre a análise do discurso que empreendemos - que pressupõe esta definição de interdiscurso - com a pragmática, ou uma teoria geral da comunicação humana (como se verá mais adiante).

\subsubsection{Universo, campo e espaço discursivos / formação discursiva}

Os conceitos de universo, campo e espaço discursivos nascem do interesse de Maingueneau por delinear com bastante precisão a dinâmica dessa relação EU X OUTRO no interior de uma formação discursiva. Assim, tais conceitos interessam porque fornecem o quadro geral no qual a interdiscursividade, tal qual a entendemos aqui, se instala.

Para Maingueneau, o espaço discursivo é constituído de subconjuntos de formações discursivas que o analista julga relevantes para seu propósito. Tais subconjuntos são o resultado de uma hipótese fundamentada em um conhecimento dos textos e em um saber histórico, e serão confirmados como constitutivos de um espaço discursivo, ou não, durante a pesquisa. É no espaço discursivo que se evidencia a relação EU X OUTRO. Neste 
trabalho, o espaço discursivo é constituído por subconjuntos das seguintes formações discursivas, todas pertencentes ao campo do discurso jurídico trabalhista: a formação discursiva do trabalhador, a formação discursiva do advogado e a formação discursiva da lei. As relações EU e OUTRO que nos interessam e que produzem os sentidos que serão analisados estão formuladas, a nosso ver, nesse espaço. O conceito de espaço é, portanto, revelador da interdiscursividade.

O conceito de espaço discursivo articula-se com outros dois conceitos, mais gerais: universo e campo discursivos.

Universo discursivo é o conjunto da produção discursiva em um determinado contexto sócio-histórico. Representa necessariamente um conjunto finito, mesmo que não possa ser apreendido em sua globalidade. Este conjunto, por definição, não é passível de análise lingüístico-discursiva, portanto, não pode ser objeto de estudo do lingüista-analista do discurso. Este conceito é importante porque engloba os discursos em um conjunto significativo e intercambiante, e que só pode existir em função da interdiscursividade.

Campo discursivo é o conjunto de discursos que se encontram em concorrência e se delimitam reciprocamente em uma região determinada do universo discursivo. Tais campos não são evidentes, é preciso percorrer a história das idéias para que se possa delimitá-los, o que implica operar com escolhas e enunciar hipóteses. Isto significa que é preciso haver um sujeito empírico que, embora imiscuído em seu tempo e, portanto, limitado em sua capacidade de julgamento e ação, de alguma maneira vislumbre determinado panorama discursivo e, cognitiva e pragmaticamente, realize distinções. Assim, é possível reconhecer o campo discursivo político e distingui-lo do campo discursivo religioso, pedagógico, literário etc, embora, como toda tentativa de classificação, nem sempre as distinções sejam fáceis, já que os campos dialogam entre si e cada um traz as marcas discursivas dos demais, em maior ou menor grau, mostrando sua interdiscursividade constitutiva.

Os campos discursivos não são, portanto, estáticos. Eles se desenvolvem, consolidam-se, transformam-se através da interação com os demais campos e através das práticas 
discursivas que lhes são próprias. Tais práticas discursivas se traduzem em gêneros do discurso, sobre os quais nos deteremos em item seguinte.

Num mesmo campo discursivo, convivem formações discursivas distintas, divergentes, ou mesmo antagônicas, que têm em comum a função de preencher a respectiva formação social. Conforme esclarece Brandão (1991):

[...] pertencentes a uma sincronia dada, as formações discursivas que constituem um campo discursivo possuem a mesma formação social, mas divergem na maneira de preenchê-la, o que faz com que se encontrem em relação polêmica ou de aliança ou de neutralidade. E cada uma define sua identidade pela mediação desse sistema de diferenças. (p. 73)

Por exemplo, no campo do discurso político, em dado momento histórico e em determinado local, podemos distinguir formações discursivas liberais, neoliberais, de esquerda, etc, que cumprem papel social equivalente e se distinguem umas das outras pelo conjunto de regularidades que apresentam. Claro está que, considerando-se como pressuposta a primazia do interdiscurso, cada formação traz em si as demais. Conforme a teoria polifônica de Ducrot, nos gêneros e textos produzidos na prática discursiva de cada formação, é possível apreender vozes dissonantes, que são as pistas lingüístico-discursivas que remetem às formações discursivas com que a formação em questão dialoga.

A formação discursiva, assim, não pode mais ser compreendida como bloco homogêneo dentro de um campo discursivo, o que contraria a própria noção de primazia do interdiscurso. Como diz Brandão (1991):

Efeito da interdiscursividade, a FD se apresenta, dessa forma, como um domínio aberto e inconsistente e não como um domínio estável, a expressão cristalizada da "visão de mundo" de um grupo social. Segundo essa concepção, a FD exige uma abordagem diferente daquela dada, por exemplo, nos anos sessenta. Fazendo um balanço crítico desse período, Maingueneau (1984:30) afirma que, para revelar a identidade de uma FD, os procedimentos utilizados então consistiam na construção de núcleos de invariância em torno de alguns pontos privilegiados do discurso. Restringia-se o campo de estudo da FD, ao não se preocupar como uma conexidade mais íntima que ela pudesse manter com outras FDs. Aliás, essa relação com outras FDs era pensada apenas como uma forma de justaposição de unidades exteriores 
umas às outras. Dentro desse quadro, o interdiscurso só podia ser compreendido como um conjunto de relações entre diversos “intradiscursos” compactos. (p. 74)

\subsubsection{Gêneros do discurso e cena enunciativa}

Em Genèses du discours (1984), Maingueneau esboça sua semântica global sem ainda desenvolver o conceito de gênero do discurso. No entanto, o essencial já está lá colocado, e veio dar substância ao conceito de gênero que vem sendo desenvolvido e aprimorado pelo autor há vários anos: trata-se do conceito de competência discursiva, na ocasião tratado como hipótese para a compreensão da produção do sentido do ponto de vista discursivo.

O conceito de competência discursiva refere-se à habilidade desenvolvida pelo falante de, por um lado, formular enunciados bem formados discursivamente (ou seja, adequados à situação de comunicação, que é determinada pelo contexto sócio-histórico e, portanto, alinhada a certa formação discursiva) e, por outro, de produzir número ilimitado de enunciados pertencentes a tal formação. Tal competência é de fato interdiscursiva, pois permite ao falante reconhecer: (i) a incompatibilidade dos enunciados com a formação discursiva em pauta; e (ii) a conseqüente presença de um espaço discursivo que constitui o OUTRO.

Esta competência se desenvolve em função de um sistema de restrições semânticas, que coage o falante, impedindo-o de formular enunciados que estejam fora das determinações específicas de certa formação discursiva. Esse mesmo sistema de restrições coage o falante a interpretar os enunciados do OUTRO de acordo com categorias pertencentes às formações discursivas a partir das quais ele fala.

A força do sistema de restrições semânticas equivale à força que as leis gramaticais exercem sobre a língua. Sua função é a de operar a coesão semântica do discurso de forma regrada. Assim, excluem-se de certa formação discursiva, por exemplo, palavras pertencentes a campo lexical alheio à dita formação. Da mesma forma, a estrutura sintática irá moldar-se de acordo com a formação discursiva, excluindo de seu campo de seleção, por exemplo, a possibilidade de uso de um sujeito sintático em primeira pessoa. É o que ocorre 
no gênero petição trabalhista, produção lingüístico-discursiva do discurso jurídico trabalhista, em que o sujeito sintático em primeira pessoa jamais coincide com o sujeito discursivo trabalhador.

A hipótese de uma competência discursiva regrada pretende, em suma, sugerir a existência de uma instância estruturante relativamente estável dentro de certos limites históricos. Trata-se de uma hipótese útil que busca responder à questão de como os enunciados aparecem e como tomam o lugar de outros. É útil também porque ajuda a esclarecer a articulação do discurso e a capacidade dos sujeitos de interpretar e produzir enunciados relevantes.

A competência discursiva, ou melhor, interdiscursiva, pressupõe compreender que a comunicação humana só faz sentido num quadro sócio-histórico específico, que conta com sujeitos falantes que podem, graças a tal competência, articular sua fala em função do OUTRO e com o OUTRO de forma regrada.

O conceito de gênero de discurso, visto da perspectiva da competência discursiva, é quase que sua conseqüência prática inevitável. Ora, se regras de restrições existem, se a situação de fala é determinada pela formação discursiva, se os sujeitos falantes se submetem a essas regras para viabilizar a comunicação e a produção dos saberes nas diferentes áreas da atuação humana, o gênero passa a ser a possibilidade material concreta de viabilizar esta comunicação e esta produção de saber, respeitadas as restrições.

A fala que comunica e constrói não precisa (nem poderia) partir do zero. Como afirma Bakhtin: "se não existissem os gêneros do discurso e se não os dominássemos, se tivéssemos de criá-los pela primeira vez no processo da fala, se tivéssemos de construir cada um de nossos enunciados, a comunicação verbal seria quase impossível” (1992:302). A comunicação humana se dá, assim, a partir de um conjunto sólido já comunicado e construído, que os gêneros representam e consolidam. 
Graças à competência discursiva, o locutor aprende a distinguir e a usar os gêneros do discurso, assim como aprende as formas prescritivas da língua (seus componentes e estruturas gramaticais). Afirma Bakhtin:

Os gêneros do discurso são, em comparação com as formas da língua, muito mais fáceis de combinar, mais ágeis, porém, para o indivíduo falante, não deixam de ter um valor normativo: eles lhe são dados, não é ele que os cria. É por isso que o enunciado, em sua singularidade, apesar de sua individualidade e de sua criatividade, não pode ser considerado como uma combinação absolutamente livre das formas da língua, do modo concebido, por exemplo, por Saussure (e, na sua esteira, por muitos lingüistas). (1992:304)

Embora não faça parte desta análise o estudo da manifestação da singularidade e da individualidade dos enunciados, já que a proposta central é apreender as regularidades que constituem os gêneros estudados e os sentidos que produzem enquanto gêneros com função social definida, representativos de certa FD, vale ressaltar a importância da afirmação de Bakhtin quanto a estes pontos e estabelecer relações que nos interessam mais diretamente. De fato, tivemos a oportunidade de ler petições trabalhistas redigidas por dois advogados distintos e foi possível apreender diferenças que podem ser atribuídas, num primeiro momento, a questões de estilo, entendido de forma convencional (que atribui tais diferenças à manifestação lingüística da individualidade). Audiências trabalhistas conduzidas por juízes diferentes também possuem diferenças de “estilo”. No entanto, em qualquer caso, permanecem ativas as restrições genéricas, sobre as quais nos deteremos adiante. A nosso ver, e de acordo com Maingueneau, elementos novos têm, sim, espaço para se instalar nos gêneros discursivos e manifestam-se nas produções textuais específicas. No entanto, como já foi dito, a transformação só pode ocorrer porque os discursos primeiros já trazem em si o diálogo com os Outros que torna o novo possível.

A nosso ver, o que à primeira vista são diferenças “estilísticas” que marcam individualidades, são de fato marcas lingüísticas que apontam para um novo que se projeta para fora do texto. Na petição trabalhista, por exemplo, o sujeito discursivo advogado, respeitadas as restrições genéricas, articula o texto de modo a alcançar do juiz o ganho de causa. O “estilo” adotado visará sempre reforçar o cumprimento da função primordial do gênero petição que é justamente obter do juiz o ganho de causa. O novo que nos interessa é 
a própria construção do processo de mudança social (algo acontecerá ao sujeito trabalhador em função da petição) que o gênero ajudará a construir. O novo que nos interessa é o caminho que os textos percorrem em direção ao futuro, atuando como elementos de transformação e consolidação de novas práticas sociais. E neste ponto podemos retomar a fala de Maingueneau ao afirmar que os interdiscursos sustentam uma relação dupla com a descontinuidade: se por um lado tratam de processar a continuidade da história das idéias tradicionais, por outro trazem em seu bojo os Outros que, dialogicamente, arejam os discursos e semeiam novas idéias e novas práticas.

Retornando à competência discursiva, pode-se dizer, em síntese, que a ela cabe a função de regular a descontinuidade. No discurso jurídico trabalhista, as ações legais que buscam a validação de um direito supostamente suprimido só podem se instaurar a partir de um conhecimento prévio e regrado constituído pelos gêneros, que por sua vez trazem em si o sistema de restrições para sua execução em textos.

Quando Bakhtin define gêneros do discurso como "tipos relativamente estáveis de enunciado” (1992: 279), a seu modo pressupunha na noção de estabilidade relativa o sistema de restrições semânticas preconizado por Maingueneau. Esta estabilidade (evidentemente relativa, uma vez que não se pode compreender o discurso como algo estático) só pode ocorrer porque há regras de formação semântica, que são conformes à formação discursiva em pauta.

O que está sendo dito é muito importante para a compreensão adequada do jogo que se estabelece entre o novo e o velho que se empreende no discurso jurídico trabalhista (como, de fato em qualquer discurso, em especial os institucionalizados, que possuem uma função social muito bem definida - apontando para o novo, para o futuro - e uma tradição que lhe garante os fundamentos para suas ações - apontando para o velho, para o passado). Nesse movimento, vislumbra-se o embate entre EU X OUTRO de forma ampliada, pois EU e OUTRO deixam de significar sujeitos discursivos isolados empreendendo atos de fala, mas tornam-se sujeitos históricos responsáveis por empreender o novo e preservar o que é importante no velho. A ação trabalhista volta-se para o futuro, para a mudança, ancorada 
nos respectivos gêneros do discurso; ao mesmo tempo os gêneros do discurso, institucionalizados que são, salvaguardam o passado, e tudo isto sob o comando da competência discursiva dos sujeitos envolvidos.

É no gênero constituído em texto que o espaço discursivo de representação de EU X OUTRO se torna palpável. Ambos, EU e OUTRO, no texto, são co-autores do processo discursivo de transformação em direção ao futuro e de preservação em direção ao passado. No gênero, ou melhor, no texto que, a partir das coerções genéricas, constitui-se finalmente sobre a página em branco, estão expressas as relações interdiscursivas, a articulação das vozes do discurso, o OUTRO sempre-já lá, sem o que o ato de fala expresso no gênero é vazio. EU e OUTRO representam-se e são representados, e desnudam-se ao se representarem discursivamente em determinado gênero.

Pode-se dizer que no gênero do discurso estão codificados os traços característicos e as estruturas dos eventos sociais, bem como o propósito dos participantes discursivos envolvidos naquele evento (Kress, 1989). O gênero é determinado pelas coerções do discurso de que é fruto, que são determinadas por sua vez pela formação discursiva em que se insere. O texto propriamente dito é, por seu turno, determinado pelas formas e restrições semânticas próprias ao gênero dentro do qual o texto se constituirá. Claro está que tais determinações são relativas, como o são tudo em linguagem e na vida mesma. É graças a essa relatividade que o novo pode instalar-se, o que significa, em última análise, que uma produção textual específica pode contribuir para transformar um gênero ou mesmo criar outro.

No texto materializam-se as posições que os sujeitos de discurso tomarão, em função das coerções genéricas. Tais posições equivalem a formas de representação possíveis desses sujeitos no gênero. Assim é que na petição trabalhista, por exemplo (e como se verá mais detalhadamente adiante), tem-se um sujeito trabalhador representado de uma tal maneira, assim como um sujeito advogado representado de outra. O gênero, por suas estratégias de representação específicas, vai caracterizar seus sujeitos de discurso de maneira específica também, fazendo-os corresponder aos papéis sociais a que tais sujeitos de discurso se 
referem. O sujeito discursivo trabalhador que aparece na petição trabalhista não é o mesmo sujeito discursivo trabalhador que aparece no jornal sindical, ou no manual de operações da fábrica, ou ainda no relatório do departamento de recursos humanos.

O sujeito de discurso representado num texto de determinado gênero constrói uma posição de sujeito como ator social. Os sujeitos que se articulam em discurso são a contrapartida discursiva da construção social promovida por atores do “mundo real”, daí serem os gêneros do discurso uma fonte riquíssima de conhecimento sobre tais atores sociais, seu perfil, o modo como operam com as categorias passado e futuro (o novo e o velho) no tempo presente da enunciação. E este presente enunciativo está na materialidade do gênero expressa no texto.

As representações podem, graças à noção de estabilidade relativa, ser re-estruturadas na interação. Daí compreendermos que, em discurso, os papéis dos sujeitos podem mudar, assim como sua contrapartida como sujeitos-atores sociais.

Os sujeitos em discurso podem, assim representarem-se a si e aos Outros de acordo, por um lado, com as coerções genéricas (o que restringe a instauração do novo) e, por outro, de acordo com as possibilidades oferecidas pela construção da cenografia discursiva (o que amplia o potencial de instauração do novo).

Neste ponto chegamos a um cruzamento de conceitos importante para a produtividade da análise que se empreenderá. O que faremos é partir do conceito de gênero do discurso, conforme o enuncia Bakhtin (1992), ampliá-lo de acordo com os estudos de Maingueneau (1984, 1995, 1999, 2003) e inseri-lo no conceito de cena enunciativa (ou cena da enunciação), também conforme Maingueneau. Antes de explicitarmos porque tal cruzamento torna-se produtivo em nossa análise, convém nos determos mais longamente no conceito de gênero, conforme seu idealizador, Mikhail Bakhtin, e conforme os recentes estudos de Dominique Maingueneau. 


\section{Gêneros do discurso conforme Bakhtin}

Brandão (2000) sintetiza muito bem a problemática dos gêneros conforme Bakhtin, dizendo da importância da insistência do autor russo em afirmar o caráter social dos fatos de linguagem, considerando o enunciado como o produto da interação social, determinado não só por uma situação material concreta como também pelo contexto mais amplo que constitui o conjunto das condições de vida de uma dada comunidade de falantes. Assim, o gênero constrói-se para além do estritamente lingüístico e implica necessariamente uma função comunicativa e social. O dialogismo constitutivo da linguagem estudado por Bakhtin está, é claro, na base da compreensão do que seja gênero do discurso. Da mesma forma, a noção mesma de gênero pressupõe a presença de EU e OUTRO atuando juntos no desenvolvimento dos diferentes gêneros.

A grande contribuição de Bakhtin à lingüística foi, grosso modo, estender os limites da competência lingüística dos sujeitos para além da frase. Essa competência está na base do conceito de competência discursiva desenvolvido por Maingueneau (conforme já foi visto).

Bakhtin define gênero desta forma:

Todas as esferas da atividade humana, por mais variadas que sejam, estão sempre relacionadas com a utilização da língua. Não é de surpreender que o caráter e os modos dessa atividade humana sejam tão variados como as próprias esferas da atividade humana, o que não contradiz a unidade nacional de uma língua. A utilização da língua efetua-se em forma de enunciados (orais e escritos), concretos e únicos, que emanam dos integrantes duma ou doutra esfera da atividade humana. $\mathrm{O}$ enunciado reflete as condições específicas e as finalidades de cada uma dessas esferas, não só por seu conteúdo (temático) e por seu estilo verbal, ou seja, pela seleção operada nos recursos da língua - recursos lexicais, fraseológicos e gramaticais - mas também, e sobretudo, por sua construção composicional. Estes três elementos (conteúdo temático, estilo e construção composicional) fundem-se indissoluvelmente no todo do enunciado, e todos eles são marcados pela especificidade de uma esfera de comunicação. Qualquer enunciado considerado isoladamente é, claro, individual, mas cada esfera de utilização da língua elabora seus tipos relativamente estáveis de enunciados, sendo isso que denominamos gêneros do discurso. (1992:279) 
Como há uma grande diversidade de esferas de atividade, que possuem práticas de comunicação próprias e refletem a diversidade das relações socioculturais, os gêneros são múltiplos e heterogêneos. Cada esfera de atividade determina seus próprios gêneros, opera as condições de funcionamento desses gêneros e coage quanto aos aspectos temático, composicional e estilístico a que cada gênero deve se submeter. Em meio a esta multiplicidade, Bahktin agrupa os gêneros em dois grandes tipos, dos quais todos os gêneros seriam subtipos: são os gêneros primários e secundários. Os primeiros se constituem em esferas de atividades ligadas às experiências cotidianas ou privadas (como exemplos citamos a conversação espontânea, os bilhetes, a conversa de elevador), em que as exigências de planejamento da fala são mínimas; os gêneros secundários constituem-se em esferas de atividade mais complexas, em geral mais formais e exigentes em termos de planejamento da fala (como exemplos citamos o romance, o teatro, o texto científico, o diálogo filosófico, etc). Os gêneros secundários absorvem e transmutam os gêneros primários, que estão na base de sua formulação.

Desde que a obra de Bahktin, em especial sua concepção sobre os gêneros do discurso, difundiu-se na Europa (e posteriormente no Brasil, há quase meio século), inúmeros estudos e tentativas de classificação têm sido feitos por lingüísticas e estudiosos da linguagem acerca dos gêneros do discurso. Em nosso trabalho, priorizamos de início a sábia conjunção preconizada por Brandão (2000), para quem a concepção bakhtiniana de gênero deve conjugar-se à tipologia proposta por Adam (1992), segundo o qual mesmo as formas mais complexas de enunciados se fundam sobre um certo número de formas elementares, provavelmente prototípicas, que são: a narração, a descrição, a argumentação, a explicação e o diálogo.

Ao conciliar os gêneros do discurso conforme os vê Bakhtin com a tipologia textual de Adam, Brandão contorna a questão da proliferação de gêneros, limitando-os não só às exigências de uma esfera social, como também a estruturas lingüísticas de composição textual, tornando a proposta bakhtiniana mais abarcável metodologicamente e, portanto, mais aplicável pedagogicamente. 
Maingueneau, por seu lado, em vez de conciliar tipologias, constrói um quadro teórico lingüístico-discursivo amplo no qual o gênero do discurso é incluído, e no qual o gênero se relaciona com tipologias textuais no âmbito do que Maingueneau chama de cenografia discursiva. A cenografia discursiva é parte do quadro geral ao qual o autor chama de cena enunciativa, noção ampla que procuraremos esclarecer a seguir.

\section{Cena enunciativa e gêneros conforme Maingueneau}

Em Maingueneau (2001), o autor afirma que “o texto não é um conjunto de símbolos inertes, mas o rastro deixado por um discurso em que a fala é encenada” (p. 84). Toda a produção discursiva estaria assim localizada num tempo e num espaço que constroem a cena e ao mesmo tempo são atualizados nela. Antes de se distinguir a que campo discursivo pertence a fala, e especificamente a que formação discursiva ela se alia, é preciso distinguir um horizonte mais amplo, palco da enunciação, em que se possam vislumbrar todos os elementos que a compõem, o que não ocorre se avaliarmos tais elementos estritamente a partir, por exemplo, da análise do discurso francesa tradicional, das diferentes teorias da enunciação ou mesmo da pragmática. Cada um desses arcabouços teóricos deixa de lado aspectos relevantes na produção de enunciados, o que, como dissemos no início deste capítulo, compromete a análise (se esta, naturalmente, ciente dos riscos, pretende-se mais abrangente, como é o caso aqui). É nesse sentido que o conceito de cena enunciativa, mesmo que elaborado muito depois do desenvolvimento inicial da semântica global, pode ser visto como pertencente a ela, constituindo-se um desdobramento de um mesmo grande esforço implícito do autor, que é o de imprimir maior unidade a diferentes correntes das lingüísticas do discurso, em prol de seu objeto de estudo.

Neste horizonte amplo que Maingueneau chama de cena enunciativa distinguem-se três cenas que, enlaçadas, articulam a produção do discurso. É na exploração do entrelaçamento dessas cenas que se encontra a riqueza de uma análise global em busca do sentido.

Maingueneau nomeia tais cenas da seguinte forma: cena englobante, cena genérica e cenografia. A cena englobante refere-se ao campo discursivo em que o discurso se produz. 
Isto significa que o leitor, ao identificar a cena englobante, identifica o texto como pertencente a determinado tipo de discurso: discurso político, discurso jurídico, pedagógico, publicitário, etc. Esta caracterização mínima não é intemporal: é ela que define a situação dos locutores em um certo quadro espaço-temporal. Daí que em determinadas sociedades do passado não se distinguia uma cena englobante especificamente política. Além do que, uma cena englobante política não é a mesma em qualquer sociedade ou em qualquer época.

Toda cena enunciativa, entendida como o entrelaçamento das três cenas mencionadas, é atravessada por vozes dissonantes (passíveis de estarem lá porque o discurso é primordialmente interdiscurso, como já foi visto), que são as marcas das formações discursivas que a constituem. ${ }^{9}$

Cada texto produzido é produzido, assim, dentro de um campo discursivo que não é estável nem homogêneo. A função social do texto nesse campo é estabilizada e expressamente determinada pelo gênero discursivo que a competência discursiva vê por bem eleger para construir o enunciado. Desta forma, chega-se à segunda cena proposta por Maingueneau: a cena genérica, que se refere aos gêneros do discurso. O leitor/produtor competente distinguirá o gênero do texto que está lendo ou desenvolverá seu texto de acordo com as restrições de determinado gênero para poder atribuir ao texto lido/produzido a sua função social. Caminhando da cena englobante à cena genérica, o leitor/produtor constrói o texto integrando-o a um conjunto de enunciados que têm um tempo e um local históricos e uma função social nesse tempo e lugar. Ao enunciar, o leitor/produtor contribui para a construção dos discursos de determinado campo e formação, sempre dialogicamente, imprimindo nos textos as marcas da interdiscursividade.

Assim é que a produção e conseqüente leitura de uma petição trabalhista, por exemplo, ocorre necessariamente no campo do discurso jurídico trabalhista (que é sua cena englobante). Constitutivamente, este discurso, para realizar-se, deve cumprir determinadas

\footnotetext{
${ }^{9}$ Nunca é demais frisar que as vozes mais proeminentes em um discurso determinam seu alinhamento a uma certa formação discursiva. Os discursos fortemente institucionalizados apresentam grande homogeneidade aparente, o que não significa ausência do Outro no discurso.
} 
funções sociais (que têm como ponto central a solicitação ao juiz de um direito do trabalhador supostamente preterido). Ao mesmo tempo, tais funções sociais só podem constituir-se dentro desse discurso para que sejam validadas. A expressão dessas funções são os gêneros próprios ao discurso em pauta, em nosso caso o jurídico trabalhista, dentre os quais destaca-se a petição, pela sua centralidade no processo trabalhista, como se verá adiante.

As cenas englobante e genérica formam o que o autor chama de quadro cênico, dentro do qual se desenvolve a terceira cena, a qual o autor denomina cenografia. A cenografia se refere aos elementos de construção textual propriamente ditos, ao tratamento do intradiscurso. A cenografia produz a imagem que corresponde a uma dada situação enunciada, e que é singular em relação a todas as demais situações equivalentes construídas nos moldes daquele gênero. O leitor/produtor da petição, por exemplo, só a pode ler/produzir se tiver em mente o quadro formado pelas cenas englobante e genérica. Entretanto, seu acesso inicial ao texto da petição (como leitor) ou sua elaboração lingüística propriamente dita (como produtor) dá-se pela construção da cenografia, que estrutura o quadro específico a ser enunciado e remete às demais cenas. Assim é que, na petição, o locutor-advogado, na posição de sujeito do discurso que enuncia em primeira pessoa, desenvolverá necessariamente uma descrição do caso jurídico em pauta, que obrigatoriamente deverá corresponder a determinadas exigências lingüísticas próprias a uma descrição. O trabalhador, expresso no texto como co-enunciador referido em terceira pessoa, é igualmente descrito e caracterizado. Esta construção lingüística organiza para o leitor do texto a imagem de uma dada situação, de uma determinada maneira. Submetido à forte coerção genérica, no entanto, o texto de qualquer petição não poderá conter em sua formulação lingüística elementos que nublem sua função social altamente institucionalizada. Por exemplo, tentativas de construir uma cenografia em que as partes mostram indignação são permitidas. No entanto, cenografias construídas com humor descaracterizam o gênero. Nesse caso, um outro quadro cênico se instala, o texto acaba sendo compreendido como uma paródia, e imediatamente deslocado do discurso jurídico trabalhista. Na prática, o humor usado em uma petição poderia comprometer a continuidade do processo e inviabilizar a solicitação trabalhista. 
Em síntese, como diz o autor, "não é diretamente com o quadro cênico que se confronta o leitor, mas com uma cenografia” (2001:87). E mais adiante:

A cenografia implica, desse modo, um processo de enlaçamento paradoxal. Logo de início, a fala supõe uma certa situação de enunciação que, na realidade, vai sendo validada progressivamente por intermédio da própria enunciação. Desse modo, a cenografia é ao mesmo tempo a fonte do discurso e aquilo que ele engendra; ela legitima um enunciado que, por sua vez, deve legitimá-la, estabelecendo que essa cenografia onde nasce a fala é precisamente a cenografia exigida para enunciar como convém, segundo o caso, a política, a filosofia, a ciência, ou para promover certa mercadoria ...” (pp. 87-88)

Dito de outro modo, é a cenografia que primeiramente desponta na materialidade do texto, constituindo-se a porta de entrada para sua compreensão. Do ponto de vista da produção textual, é no espaço cenográfico que se encontra a liberdade relativa de criação do autor. É o espaço da atualização da língua enquanto sistema, com todo o seu potencial. É fácil concluir, assim, que quanto mais institucionalizado for o gênero, menos liberdade cenográfica haverá. Em contrapartida, quanto menos institucionalizado for o gênero, maior liberdade cenográfica haverá. Se pensarmos na petição trabalhista, observaremos que o espaço para o novo é bastante pequeno. Ao contrário, se pensarmos em um manual de informática, a liberdade será maior. Se pensarmos em uma crônica jornalista, a liberdade será maior ainda. É a competência discursiva que determina o grau de potencial criador a ser expresso na materialidade lingüística. A prática da produção textual e o conseqüente incremento da competência discursiva alargam os horizontes do leitor/produtor de textos, que poderá encontrar espaços para criação até mesmo em gêneros fortemente institucionalizados, respeitado, é claro, um limite, que é variável historicamente. Isto explica as diferenças de “estilo” encontradas em petições redigidas por advogados distintos, diferenças suficientes para caracterizar diferentes cenografias, mas insuficientes para caracterizar uma mudança de gênero.

O conceito fundamental de cena de enunciação pode assim constituir-se, a nosso ver (e é o que faremos nesta tese), em eixo bastante consistente para a ampliação do potencial teórico da análise do discurso, das teorias da enunciação e da pragmática. 
A tripla articulação dos conceitos de cena englobante, cena genérica e cenografia, que definem a cena de enunciação, é, neste trabalho, o eixo teórico que gerará, de modo consistente e redimensionado, e sempre com base na primazia do interdiscurso, todos os níveis da análise que se segue.

Todos os aspectos relativos à textualização sob forma de gêneros discursivos podem ser discutidos à luz do conceito de cena genérica, assim como todos os aspectos ligados à organização textual (níveis macro e micro) podem ser abordados à luz do conceito de cenografia. Estes aspectos remeterão necessariamente à cena englobante, cuja apreensão possibilitará a melhor compreensão do interdiscurso.

Em texto avulso produzido em 2003/2004, síntese de palestra proferida na PUC-SP em 06/10/2003 ${ }^{10}$, Maingueneau discorre sobre a diversidade dos gêneros do discurso, aprofundando seus estudos a respeito, sempre de forma integrada ao conceito de cena da enunciação. Reforça que a diversidade de tipologias é um problema, já que são vários os pontos de vista sob os quais se pode observar a diversidade dos gêneros. Entre os quatro pontos de vista mais comuns, relacionados entre si (i- lingüístico: implica ruptura entre enunciado e situação de enunciação; ii- funcional: implica finalidade e abarca categorias extralingüísticas; iii-situacional: implica considerar o lugar social de onde emana a fala; ivdiscursivo: leva em conta aspectos das três tipologias anteriores), Maingueneau caminha mais próximo à tipologia que ele denomina discursiva, uma vez que tal perspectiva integra a noção de discurso constituinte (“discours constituant”"11), em desenvolvimento pelo autor já há várias décadas.

\footnotetext{
${ }^{10}$ Neste texto, Maingueneau revê a tipologia discursiva proposta em 1999, segundo a qual os gêneros discursivos pertenceriam a três grandes categorias: gêneros de autor, gêneros de rotina e gêneros conversacionais (do francês, respectivamente, "genres auctoriaux", "genres routiniers" e "genres conversationnels").

${ }^{11}$ Os discursos constituintes são discursos fundadores. Como diz Maingueneau (1995), delimitar o conjunto dos discursos constituintes é proferir a hipótese de que tais discursos obedecem a restrições quanto às suas condições de emergência e funcionamento. São essencialmente constituintes os discursos religioso, científico, filosófico, literário e jurídico.
} 
É com base nos estudos recentes sintetizados nesse texto que realizamos a análise dos gêneros selecionados nesta tese. É importante, assim, discorrer mais especificamente sobre a recente tipologia ${ }^{12}$ de gêneros proposta pelo autor. Embora Maingueneau reconheça que suas distinções possuem ainda caráter rudimentar, seus esforços conceituais conduzem à possibilidade de enxergar os gêneros de forma menos estanque, de acordo com o que chama de modos de generecidade, conceito que confere à sua tipologia uma dinaminicidade coerente com as exigências de uma semântica global.

Maingueneau propõe, como primeira distinção, os conceitos de gênero instituído e gênero conversacional. Os gêneros instituídos são sujeitos a restrições bem marcadas de duas ordens: global - as restrições ocorrem em toda a extensão do texto - e vertical - as restrições são socialmente impostas, cabendo à competência discursiva operar as seleções durante a construção do texto. Já os gêneros conversacionais sofrem restrições menos marcadas, de duas ordens: local - o controle sobre o ato de fala dá-se no momento da enunciação - e horizontal - há constante negociação entre os interlocutores sobre as regras que devem nortear a conversação. Observe-se que aqui não se estabelecem distinções entre texto oral e escrito, referindo-se o termo conversacional, portanto, à situação de emprego.

A opção do autor é desenvolver o estudo dos gêneros instituídos (que é justamente o que nos interessa neste trabalho, uma vez que os gêneros do discurso jurídico, trabalhista ou não, operam segundo as restrições global e vertical). E o faz a partir do conceito de modo de genericidade ${ }^{13}$.

O modo de genericidade é definido pela relação que cada gênero estabelece com sua cena genérica e sua cenografia. Maingueneau propõe quatro modos de genericidade, que se diferenciam pelo grau de liberdade cenográfica permitida pelo gênero e pelo grau de liberdade cenográfica efetivamente construída pelo sujeito do discurso, que pode vir, com o tempo e a repetição do uso, a consolidar uma mudança no gênero ou a constituição de um gênero novo. Um gênero, portanto, de acordo com os modos de genericidade, não se define

\footnotetext{
${ }^{12}$ Usamos a palavra tipologia por ausência de termo mais adequado. Reconhecemos o caráter estanque do termo, que procuraremos amenizar através da própria explicação da proposta de Maingueneau.

${ }^{13}$ Do francês, "modes de généricité”.
} 
de modo estanque, e é isto que permite vislumbrar a diversidade sem perder de vista um eixo comum em cada modo.

Gêneros instituídos de modo 1: são aqueles sujeitos a nenhuma ou pouquíssima variação cenográfica. Os interlocutores se limitam a obedecer às restrições genéricas. Neste caso, é praticamente impossível falar em autoria. São considerados gêneros instituídos de modo 1, por exemplo, listas telefônicas, fichas administrativas em geral, fichas de controle do tráfego aéreo, os formulários que compõem o processo trabalhista, etc.

Gêneros instituídos de modo 2: são os gêneros com formato consolidado e cenografias preferenciais, que possuem, no entanto, certa margem de liberdade, expressa na construção da cenografia. São exemplos de gêneros instituídos de modo 2, o jornal impresso, o jornal televisivo, guias de viagem, manuais, apostilas, a aula, etc. Gêneros deste modo são construídos com cenografias variadas, sem alterar o que é essencial ao gênero. O essencial em um mesmo gênero é constituído basicamente pela temática, pela organização textual e pelo papel dos participantes na situação de comunicação.

Gêneros instituídos de modo 3: são os gêneros que, embora tenham formatos estáveis, não possuem cenografias preferenciais. É da natureza de tais gêneros promover a inovação, embora tal inovação não conteste a cena genérica. Os gêneros publicitários são o exemplo mais evidente deste modo de genericidade.

Gêneros instituídos de modo 4: são os gêneros para os quais a própria noção de gênero é problemática. Possuem cenografia livre e não se contentam em contemplar um modelo de gênero, podendo construir-se de modo a subverter o gênero ou mesclar dois ou mais gêneros. Neste caso, evidencia-se a noção de autoria. Os textos construídos de acordo com este modo de genericidade trazem à superfície discursiva o sujeito autor do texto, sujeito este que pode ou não coincidir com o autor empírico. Nesses gêneros, a subjetividade é mais evidente e o diálogo EU X OUTRO, polêmico ou não, se estabelece de modo mais evidenciado na cenografia. São exemplos deste modo de genericidade, o ensaio, a tese, o editorial e todos os gêneros literários. É ainda característica deste modo a ausência de uma 
finalidade prática e imediata, estabilizada socialmente. Os gêneros pertencentes a este modo de genericidade são antes de mais nada o local para a construção da identidade do sujeito do discurso através de sua enunciação.

Conforme afirma Maingueneau em seu texto de 2003, os modos 3 e 4 são próximos devido a dois aspectos: não se contentam em seguir um modelo e pretendem atingir seu público instaurando uma cena enunciativa original que dá sentido à sua própria atividade verbal. Os gêneros de modo 4, no entanto, apresentam uma característica fundamental que os diferencia dos demais: são gêneros cuja cena genérica apresenta uma incompletude constitutiva. Nela há um sujeito do discurso que autocategoriza sua produção verbal. Denominações como “meditação”, “utopia”, etc, são mais do que rótulos a denominar um gênero ou etiquetas para identificar uma prática verbal, são contribuição decisiva para definir de que modo e a que título o texto correspondente deve ser recebido. Tais denominações são a conseqüência de uma decisão que participa de um ato de posicionamento no interior de um certo campo e que está associada a uma memória intertextual. É pela relação com esta memória que os atos de categorização genérica adquirem sentido e é esta memória que conserva o traço do gesto autoral.

A petição trabalhista e a audiência podem ser analisadas como gêneros produzidos na fronteira entre os modos 1 e 2. Nesses gêneros, a sujeição à cena da enunciação é alta, a noção de autor inexiste e a finalidade prática é consolidada e reconhecida. Embora a petição seja assinada pelo advogado do cliente-trabalhador, esta assinatura é exigência formal do gênero e refere-se mais a um local sócio-histórico de onde emana a fala e menos a um sujeito autor que está ali autocategorizando sua fala e construindo sua identidade. Na audiência, da mesma forma, a construção das falas dos presentes não equivale à construção de identidades em interlocução, estando tais falas ali configuradas com um propósito social altamente estabilizado. Há, ainda assim, em ambos os gêneros, certa liberdade cenográfica. Os formulários do processo trabalhista, por sua vez, são claramente produções genéricas produzidas de acordo com o modo 1. A entrevista inicial cliente-trabalhador pode ser analisada como pertencente ao modo 2, por sua maior flexibilidade cenográfica. 
Pode-se sintetizar os quatro modos de genericidade da seguinte forma, considerando-se o sinal de “+” como indicador de presença do item em pauta e o sinal de “-” como indicador de sua ausência:

\begin{tabular}{|l|ll|ll|l|}
\hline MODO & $\begin{array}{l}\text { SUJEIÇÃO ÀO } \\
\text { ENUNCIATIVA }\end{array}$ & CENA & $\begin{array}{l}\text { NOÇÃO } \\
\text { AUTOR }\end{array}$ & $\begin{array}{l}\text { FINALIDADE } \\
\text { PRÁTICA }\end{array}$ \\
\hline 1 & +++ & --- & +++ \\
\hline 2 & ++- & --+ & ++- \\
\hline 3 & +-- & -++ & +-- \\
\hline 4 & --- & & +++ & --- \\
\hline
\end{tabular}

Observe-se que quanto maior a sujeição às restrições da cena enunciativa e quanto mais evidenciada a finalidade prática do gênero, menos presente está a noção de autor. Consideramos que a finalidade prática socialmente estabelecida e a sujeição do gênero às coerções da cena enunciativa são mutuamente determinantes. Ambas, por sua vez, determinam o nível de subjetividade permitido no gênero. E não poderia ser diferente, uma vez que a subjetividade é responsável pela ruptura das práticas discursivas, daí dever ser contida quando a prática discursiva implica uma prática social que não pode deixar de ser realizada de uma certa maneira. Dito de outro modo, quanto mais a função social do gênero voltar-se às atividades práticas das diferentes esferas de atuação do homem, mais apagada a noção de autor. Da mesma forma, quanto mais apagada a noção de autor, menor o espaço para a criação e a transformação (menos espaço para o novo) e maior o espaço para a perpetuação do convencional (mais espaço para o velho). Voltaremos a este ponto mais adiante.

Para encerrar estas reflexões sobre cena da enunciação e gênero, gostaríamos de estabelecer algumas relações entre a tripartição proposta por Maingueneau quanto à cena da enunciação e a tripartição proposta por Bakhtin quanto à questão dos gêneros do discurso.

Os gêneros do discurso, para Bakhtin, se distinguem uns dos outros por três elementos centrais e essenciais a cada gênero: conteúdo temático, composição e estilo. Cada gênero é 
reconhecido como tal pelas particularidades apresentadas em cada um desses níveis. Assim, a petição trabalhista é reconhecida como tal por apresentar como conteúdo temático sempre a solicitação de um direito supostamente suprimido ao trabalhador, por ser composta necessariamente a partir de uma estrutura textual fixa, e por apresentar a linguagem própria ao discurso jurídico, com suas estruturas frasais e léxico pré-definidos.

A cena da enunciação, como vimos, é constituída por três cenas que, entrelaçadas, constituem o próprio sentido do texto: cena englobante, cena genérica e cenografia. O gênero do discurso corresponde à cena genérica, estando, portanto, a tripartição proposta por Bakhtin inserida na tripartição proposta por Maingueneau.

Observe-se ainda que os níveis que compõem o gênero se relacionam com os níveis que compõem a cena da enunciação. Assim, o conteúdo temático se relaciona com a cena englobante, já que a temática só pode surgir em função do campo e da formação discursiva aos quais se filia o gênero. A composição se relaciona com a cena genérica, uma vez que a estrutura relativamente fixa do texto de um gênero é o elemento que mais imediatamente identifica o gênero enquanto tal, em especial os gêneros institucionalizados (ou instituídos, conforme Maingueneau). O estilo, finalmente, se relaciona com a cenografia, uma vez que são as opções de ordem mais estritamente lingüísticas que compõem a imagem suscitada pela cenografia. O gráfico a seguir procura mostrar tais relações: 


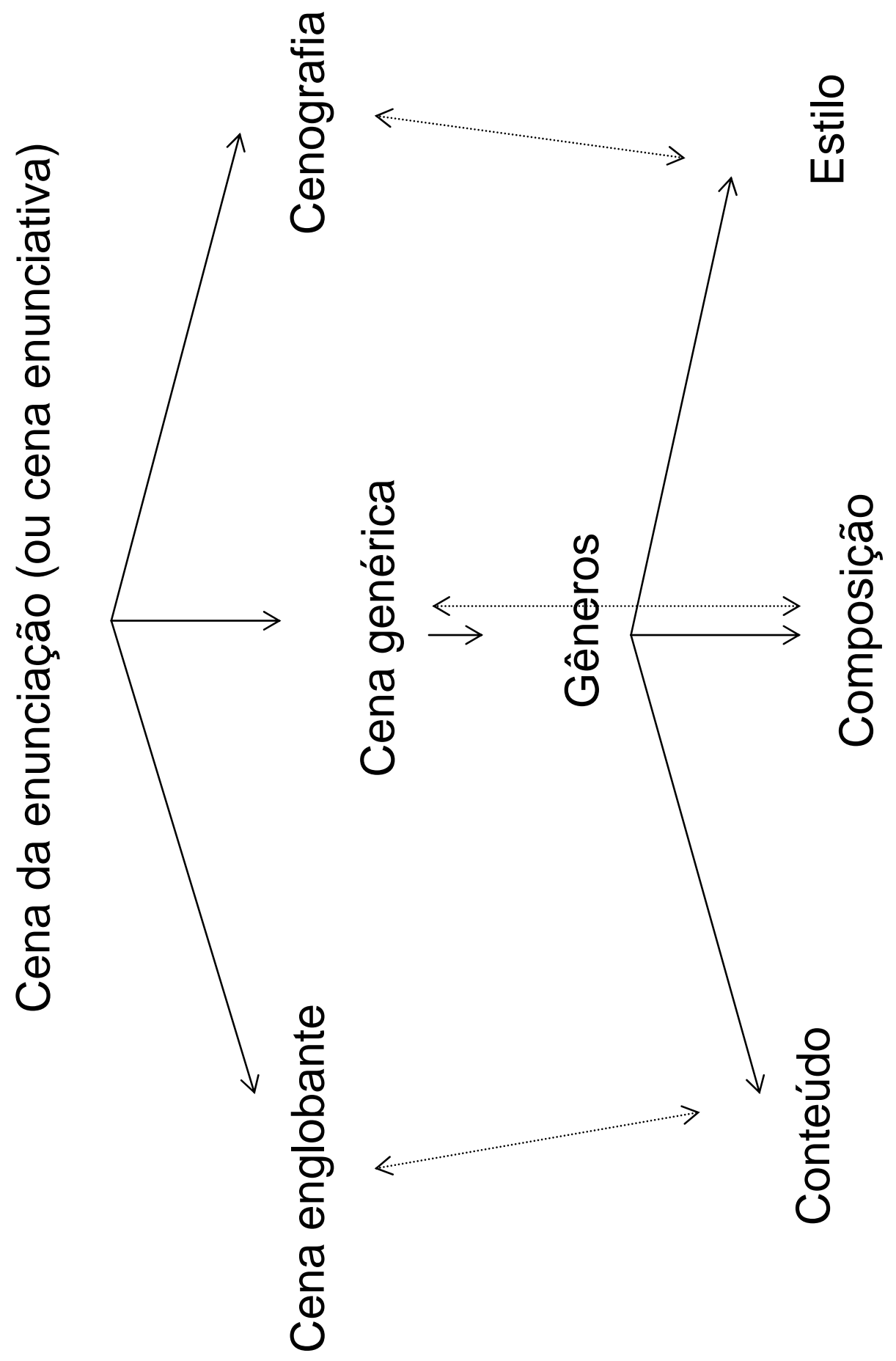


Estas relações apontam para a dinamicidade dos conceitos utilizados pelos autores, ajudando a costurar vácuos e possibilitando a visualização do discurso como movimento contínuo no seio das comunidades de falantes. É neste constante fluir que os interdiscursos podem ser compreendidos como prioritários em relação aos discursos. É no movimento interdiscursivo que as falas se cruzam e se constroem mutuamente. Atualizados na prática discursiva, os enunciados constituídos em gêneros, prenhes de vida, recuperam o velho e criam o novo, apontam para o passado e constroem o futuro.

O conceito amplo de cena enunciativa permite compreender como se dá o grande esforço discursivo que é empreendido nas diferentes esferas da ação humana. Assim as escolhas discursivas operadas pelos falantes não podem mais ser vistas como aleatórias ou mesmo ingênuas, cabendo ao analista apreender as relações que cada texto, enquanto mostra material e palpável do discurso, mantém com sua formação discursiva original e que sentidos produz na interação com as demais. É importante não perder de vista que os discursos que constituem os diferentes campos e formações discursivas são sempre-já constitutivos das vozes do OUTRO. Estes conceitos chave, somados aos conceitos explicitados nos itens 2.2 a 2.6, constituem o quadro teórico lingüístico-discursivo para a análise do corpus que se empreenderá no capítulo 5. 


\subsection{O diálogo com a pragmática}

\subsubsection{Semântica global e pragmática}

Como dissemos, Maingueneau (1984) busca construir as bases para o que chama de semântica global, que é uma semântica que não privilegia tal ou tal plano semântico, mas que integra todos eles e investiga o discurso em suas múltiplas dimensões. Tal teoria é adotada como base teórica importante para nossa análise, pelo saudável alargamento teórico que propicia à $\mathrm{AD}$ e pelas possibilidades que abre para o diálogo com outras disciplinas, como a pragmática (conforme o próprio Maingueneau sugere no Avant-Propos de Genèses du Discours, à página 15).

Os conceitos já explicitados de discurso, interdiscurso, universo, campo, espaço e formação discursivos são a base da semântica global, passíveis de serem abarcados pelo conceito de cena da enunciação. Outros conceitos importantes, de cujas noções Maingueneau se apropria, e aos quais chama de planos semânticos, são: intertextualidade, vocabulário, temas, estatuto do enunciador e do destinatário, dêixis, modo de enunciação e modo de coesão. Não há ordem de importância entre os planos semânticos (como na visão tradicional que assume a importância crescente dos planos lexical ao filosófico). É possível, no entanto, compreendê-los a partir do conceito de cena da enunciação e, em função disto, estabelecermos uma hierarquia de outra ordem. Os temas estão relacionados à cena englobante; o estatuto do enunciador e do destinatário estão relacionados à cena genérica; intertextualidade, vocabulário, dêixis, modo de enunciação e coesão estão relacionados à construção da cenografia. Juntos, todos esses conceitos delineiam um "esquema construtor" global que representa a competência discursiva investida em cada um deles. Por competência discursiva Maingueneau entende o domínio das regras de boa formação semântica pelo enunciador.

A hipótese da competência discursiva apresenta a vantagem de não supor uma exterioridade absoluta entre a posição enunciativa e os sujeitos que a venham ocupar. Tal princípio permite esclarecer um pouco a articulação do discurso e a capacidade dos sujeitos de interpretar e produzir os enunciados relevantes. O sujeito empírico produtor dos enunciados 
não é nem absolutamente livre para dizer o que quiser, como e quando quiser, nem completamente assujeitado às coerções discursivas. Esta instabilidade, este jogo de forças, é o que dá margem ao novo no discurso.

Pode-se dizer que a competência discursiva é dupla: de reconhecimento dos enunciados como "bem formados", por um lado, e de capacidade de produzir um número ilimitado de enunciados inéditos pertencentes a uma certa formação discursiva. A competência discursiva deve ser entendida de fato como competência interdiscursiva, o que significa possuir ainda: a aptidão de reconhecer a incompatibilidade semântica de enunciados de formações de um espaço discursivo que constitui o OUTRO; e aptidão de interpretar, traduzir esses enunciados de acordo com categorias de seu próprio sistema de restrições. Poderemos observar durante a análise que faremos que é devido à competência discursiva que o locutor-advogado realiza satisfatoriamente a passagem entre um modo de enunciação na entrevista e outro na petição, efetivando a apropriação de um EU que se transfigura em OUTRO e consolidando um novo nível intertextual e interdiscursivo.

O conceito de competência discursiva pode dar conta, em boa medida, das regularidades interdiscursivas historicamente definidas do espaço discursivo em questão, que regulam o processo de apropriação e representação da voz do trabalhador. Observe-se ainda que o grau de coesão discursiva que a competência discursiva constrói não é necessariamente equiparável ao grau de coesão social dos indivíduos que fazem parte das formações sociais representadas, ao mesmo tempo em que um único indivíduo dito representativo de uma formação social é necessariamente atravessado por várias formações discursivas.

O corpus selecionado é significativo desta posição, uma vez que explicita, ao constituir-se como espaço discursivo de vozes que ocupam lugares sociais tão diversos e que, portanto, articulam saberes que em geral não se articulam entre si, a possibilidade de construção de um discurso que, de um jeito ou de outro, integra tais vozes em uma determinada direção argumentativa. Trata-se de uma coesão construída que vai além da coesão social dos representantes empíricos de tal discurso. 
Passamos a uma breve descrição dos planos semânticos delineados por Maingueneau. Tais planos estarão sendo levados em conta na análise do corpus. Se não forem claramente explicitados como tópico de análise, estão com certeza implicados como pano de fundo teórico.

Os temas: Maingueneau define este plano intencionalmente da forma mais vaga: os temas são o "de que trata o texto". Assim como no que se refere ao vocabulário, o que importa não é tanto listar os temas abarcados por tal discurso, mas sim reconhecer de que forma tais temas são tratados semanticamente. De qualquer forma, as coerções discursivas privilegiarão certos temas em detrimento de outros. Assim, em um espaço discursivo:

- Um discurso integra semanticamente todos os seus temas de acordo com seu sistema de restrições.

- Esses temas se repartem em dois subconjuntos: os temas impostos e os temas específicos.

- Os temas impostos se dividem em temas compatíveis e temas incompatíveis. Os incompatíveis, embora não convergentes semanticamente de acordo com o sistema de restrições, são integrados em virtude da proposição.

- Os temas específicos são próprios a um discurso. Sua presença se explica por sua relação privilegiada com o sistema de restrições.

No discurso jurídico trabalhista, os temas são determinados pelo que permite a CLT (Consolidação das Leis do Trabalho).No entanto, realidades específicas de um determinado trabalhador, textualizadas em entrevista inicial com o advogado, podem ser trazidas para o âmbito dos temas permitidos, através de ajustes lingüístico-discursivos feitos pelo advogado, que domina o discurso jurídico trabalhista, discurso a partir do qual determinada realidade será construída e validada.Temas específicos trazidos pelo trabalhador, e pertencentes ao campo discursivo do trabalho (representado principalmente pelo discurso sindical e pelo discurso empresarial e respectivas formações discursivas), só são trazidos para o âmbito dos temas permitidos se mantiverem relações privilegiadas com os temas do 
discurso jurídico trabalhista. E isto ocorre se sua inserção na construção da direção argumentativa puder contribuir para o atendimento da solicitação trabalhista.

O estatuto do enunciador e do destinatário: os diversos modos de subjetividade dos sujeitos do discurso dependem igualmente da competência discursiva. Cada discurso define o estatuto que se deve conferir ao locutor-enunciador e este a seu destinatário para legitimar seu dizer. No discurso jurídico trabalhista, o estatuto dos enunciadores/interlocutores é claramente definido. A voz do trabalhador é apropriada pela voz do locutor-advogado, que assume assim papel secundário na interlocução com o destinatário final, a saber, o juiz trabalhista. O enunciador advogado, por sua vez, modula sua voz de acordo com as restrições do discurso, a fim de fazer aceitar sua argumentação pelo juiz trabalhista, que representa o detentor máximo do saber, seja o específico (do direito trabalhista), seja o lingüístico-discursivo, que constrói, materializa e tende a perpetuar tal saber. Os modos de subjetividade são apreendidos pelas formas de representação de tais sujeitos no discurso.

A intertextualidade: é o conjunto de tipos de relação intertextual que a competência discursiva define como legítimo, a partir do qual se admitem certos tipos de filiação e se recusam outras. No nosso trabalho, os textos constituídos a partir de retextualização são exemplo de intertextualidade, embora, como a retextualização gera textos pertencentes a gêneros discursivos diferentes dos gêneros originais e desloca o estatuto do sujeito da enunciação, a percepção imediata do intertexto possa ser prejudicada.

É um desafio importante para que haja a melhor apreensão dos sentidos produzidos no discurso jurídico trabalhista observar como, pela retextualização com mudança de gênero e deslocamento do sujeito da enunciação, produzem-se apagamentos lingüísticos que geram apagamento de sentido. Produzem-se também transformações textuais que geram novos sentidos, com a ressalva de que aqui o "novo” é restringido pelas coerções próprias ao discurso. A apreensão das marcas lingüístico-discursivas deste nível de intertextualidade exige que se considere todo o texto como intertexto, assim como todo discurso como interdiscurso. 
O vocabulário: conjunto de palavras que condensam o que há de essencial no discurso. Constituem-se pontos de cristalização semântica e aparecem sistematicamente nos textos representativos de um determinado discurso. O universo lexical é restringido pelas coerções do discurso. Entre vários termos a priori equivalentes, serão utilizados os que marcam uma posição no campo discursivo. Este ponto é também evidente ao se analisar os textos fruto do discurso jurídico. Importa frisar que, em tais análises, o simples levantamento lexical, desprovido de relações discursivo-pragmáticas mais amplas, pode significar perda de sentido. É o caso das expressões nominais definidas analisadas na petição trabalhista (ver item 5.4).

A dêixis enunciativa: o ato de enunciação supõe a instauração de uma dêixis espaçotemporal que cada discurso constrói em função de seu próprio universo. Não se trata de datas, mas de um espaço-tempo criado no discurso e que não coincide com a realidade biográfica dos sujeitos sociais. Nas petições trabalhistas analisadas, um exemplo simples que constata a instauração de uma dêixis própria dá-se no que se refere à adaptação dos horários em que o trabalhador efetivamente realizou suas tarefas aos horários pretensamente acordados entre empregado-empregador. A criação desta dêixis é construída no texto oral da entrevista inicial pelos interlocutores e configurada lingüisticamente no texto da petição. A dêixis enunciativa instaura também as pessoas que se constituirão em sujeitos do discurso: EU e TU. Pode-se dizer que a dêixis enunciativa (ou discursiva) é o eixo do sistema de referências intra e interdiscursivas que a enunciação necessariamente cria a fim de instaurar um sujeito da enunciação e os co-enunciadores, e situar o ato enunciativo num certo tempo e lugar. Esse sistema possui também mecanismos para apontar no texto $e$ no discurso os sujeitos referidos pelos co-enunciadores EU e TU, que aparecem no texto como ELE. É o caso, na petição trabalhista, do sujeito trabalhador, referido anaforicamente por determinados lexemas que apontam simultaneamente para uma terceira pessoa mencionada no início do texto da petição (Fulano de Tal, autor da petição através do advogado Beltrano) e para o sujeito discursivo trabalhador, um dos enunciadores do texto (conforme uso feito por Ducrot em sua teoria polifônica da enunciação). Assim, o uso anafórico de lexemas como “requerente” e “reclamante” possui um valor que extrapola 
os limites do texto. Daí considerarmos a anáfora, como veremos adiante, de uma perspectiva discursiva. Conforme diz Levinson (1983):

[...] there are good arguments for considering that anaphora ultimately rests on deictic notions (Lyons, 1977a:671). Such a conclusion would have important repercussions for the philosophical worries about the deictic nature of reference. (p. 87) ${ }^{14}$

O modo de enunciação: refere-se à maneira de dizer específica de um tal discurso. É o tom do discurso. Este plano confere ao enunciador sua corporalidade, sua personalidade. É o aspecto que sustenta no discurso as disposições psicológicas a serem suscitadas e a própria possibilidade de estabelecer relações no mundo. O destinatário é, assim, assumido no corpo do discurso, que se reveste de uma certa maneira de ser através de uma certa maneira de dizer. É muito interessante notar como o locutor-advogado reveste-se de modos de enunciação completamente diferentes na entrevista com seu cliente e na petição dirigida ao juiz. Sem tal articulação no modo de enunciação, não haveria de fato compreensão nas respectivas instâncias discursivas.

O modo de coesão: refere-se à intradiscursividade própria a cada formação discursiva, à maneira como um discurso constrói sua rede de apresentações internas. Este plano recobre fenômenos diversos, como a constituição dos gêneros e a formação dos encadeamentos discursivos na superfície textual. Assim, a análise da textualização da "entrevista”, assim como da "petição trabalhista", que se opõem em níveis tais como: oral/escrito, formal/informal, texto tenso/distenso etc., deve ser avaliada para a melhor apreensão do sentido construído. Tais aspectos direcionam a escolha lexical e a construção morfossintática, assim como a topicalização e toda a direção argumentativa, e representam a gramaticalização/materialização do discurso. Consideramos o modo de coesão o aspecto central para a construção da cenografia discursiva, estando todos os demais aspectos de construção gramatical a ele submetidos. Neste ponto, nossa análise recorrerá aos ensinamentos da lingüística textual de caráter pragmático (de Marcuschi) e da semântica argumentativa, que oferecem os instrumentos importantes para esta primeira entrada no

\footnotetext{
${ }^{14}[\ldots]$ há bons argumentos para considerar que a anáfora se apóia, em última análise, na noção de dêitico. Tal conclusão teria repercussões importantes na reflexão filosófica sobre a natureza dêitica da referência.
} 
texto, pois apontam para elementos do nível estritamente lingüístico relacionando-os diretamente com elementos significativos dos demais níveis discursivos (abarcados pela cena genérica e cena englobante).

A partir de tudo que se disse sobre a semântica global de Maingueneau, pode-se desde já configurar as possibilidades de diálogo entre esta e a pragmática. Para começar, iremos nos remeter a Possenti (2002) e reproduzir trechos da reflexão sobre este assunto que o autor realiza em um dos artigos do livro:

A propósito, este parece ser o momento certo de enunciar um truísmo: exatamente porque as teorias são históricas é que estão sujeitas à história, e é fortíssima a hipótese de que a história ainda não tenha acabado. A carruagem não corre apenas para estar na história até um certo momento (modestamente, aquele em que estamos), mas também para ir adiante, embora, provavelmente, para uma direção imprevista e até mesmo indesejada.

[...]

A inclusão ou exclusão, em uma teoria do discurso, de pontos de vista da pragmática, da história ou da psicanálise não é obviamente uma questão simples: nem se deve crer que seja ditada apenas pelos fatos, o que seria empirismo grosseiro, nem que seja ditada exclusivamente pela decisão do pesquisador de favorecer uma hipotética pureza teórica. Trata-se, em geral, de uma questão de política de conhecimento. Mas pode ser, também, e freqüentemente o é, uma questão de preferência (o que não significa que se trate de gosto pessoal; este tipo de psicologismo provavelmente pode mesmo ser descartado). Muitas vezes, também, trata-se de pôr em relevo um dos aspectos do problema. E afirmar que determinado aspecto é relevante não deveria significar (que se quer dizer) que se trata do único aspecto relevante. É relativamente freqüente, tanto nas chamadas ciências da natureza quanto nas chamadas ciências humanas, que uma teoria não seja global (...). É especialmente em teorias que consideram constitutiva a idéia da dispersão dos discursos que seria estranho que as teorias dos outros ou as outras teorias não pudessem ser consideradas e, mesmo, parcialmente apropriadas. Sobretudo quando os gestos de apropriação foram constitutivos do campo, como é o caso da Análise do Discurso. (pp. 138-139) (grifo nosso)

O trecho grifado nos interessa em especial, pois vai ao encontro dos próprios pressupostos da semântica global de Maingueneau, indiscutivelmente representativa da Análise do Discurso e assumida nesta pesquisa como o corpo teórico mais produtivo em $\mathrm{AD}^{15}$. Admitindo-se que a hipótese da primazia do interdiscurso é das mais produtivas, ou seja,

\footnotetext{
${ }^{15}$ Referimo-nos à AD de origem francesa, embora hoje observemos um diálogo bastante produtivo entre a AD de origem francesa e a Análise Crítica do Discurso, de origem inglesa.
} 
admitindo-se (como estamos fazendo) que os discursos se constituem como relação intrínseca de um EU com seu OUTRO, a ponto de considerarmos o interdiscurso como o lugar da produção do sentido, é no mínimo desejável que a $\mathrm{AD}$ como um todo assimile para si, enquanto disciplina que se constrói no movimento da história, a abertura para o Outro implicada em seus pressupostos.

Se uma política do conhecimento aliada a certa preferência pessoal (ou melhor, à preferência de um grupo de pesquisadores) privilegia certas teorias, cabe a uma disciplina crítica como a $\mathrm{AD}$ apontar para tais movimentos, descrevendo-os criticamente, e incorporando o Outro (outras teorias) aos seus pressupostos, de modo a melhor realizar sua tarefa.

Compreender que a história nos leva a caminhos imprevistos faz parte do entendimento que uma ciência deve ter de si mesma como ciência que se coloca em um tempo e em um espaço. Isto não significa reduzir o nível de auto-exigência e coerência interna, mas sim realizar um árduo trabalho de definição clara de critérios fundamentais, que devem trazer em seu bojo o espaço para o Outro. De acordo com Maingueneau, trata-se de se observar no próprio discurso da $\mathrm{AD}$ o que permite e o que não permite a constituição de discursos segundos que o ameacem em seus fundamentos. Na prática discursiva, ocorre que, como já foi dito, o discurso primeiro se apropria do que deverá se tornar um discurso concorrente e o apreende como uma figura privilegiada do seu OUTRO. Visto deste ângulo, o risco da disciplina descaracterizar-se enquanto tal se minimiza, senão desaparece.

De uma maneira inicial e geral, podemos destacar dois níveis de aproximação dialógica nas relações entre semântica global (que pode ser entendida como sendo a análise do discurso proposta por Maingueneau) e pragmática. O primeiro pode ser denominado nível do acontecimento. Para a semântica global, como já foi dito, todo processo discursivo, que é de fato sempre interdiscursivo, é um acontecimento social e histórico. Por admitir a existência de um sujeito empírico que atua cognitivamente no discurso, o processo discursivo é também acontecimento subjetivo/individual. Sendo acontecimento em ambas as perspectivas, o processo interdiscursivo passa a fazer parte do âmbito da ação humana, 
mais especificamente, da ação humana produtora de linguagem. Para a pragmática, discurso é ação, é a linguagem em uso pelos seus usuários, é a produção discursiva dos indivíduos em suas práticas sociais, sem excluir o aspecto ideológico que perpassa e é constitutivo de tal produção (ver Mey, 2001).

Da perspectiva pragmática, o sujeito do discurso é também social e individual ao mesmo tempo. Mey (2001) procura marcar esta simultaneidade utilizando o termo "societal", que dilui a dicotomia convencional entre indivíduo e sociedade. Poderíamos dizer que o indivíduo se constitui enquanto tal nas relações sociais. Daí ser possível falar em formação societal, no lugar de formação social, por exemplo, com o objetivo de marcar esta imbricação intrínseca ao processo interdiscursivo.

Caminhando nesta direção, podemos entrever o segundo ponto de encontro entre a semântica global e a pragmática, que é justamente a constituição conjunta da convencional polaridade EU X OUTRO. Não importa que na semântica global este EU se refira imediatamente a um sujeito do discurso e que na pragmática este EU se refira imediatamente a um sujeito empírico/individual. Também não importa que na semântica global este OUTRO se refira ao outro no discurso e que na pragmática este OUTRO se refira muitas vezes a tudo o que é coletivo, social, ou a um interlocutor empírico. Importa que existe em ambas as disciplinas o mesmo apagamento da dicotomia tradicional, a mesma decisão de considerar a produção de linguagem como produto da interlocução entre sujeitos, e assim heterogênea por natureza. Esta visão de linguagem é o segundo nível de aproximação dialógica entre as duas correntes teóricas em pauta.

\section{Uma breve reflexão sobre a pragmática}

Para aprofundarmos os pontos comuns que nos permitem aproximar semântica global e pragmática (e assim tornar coerente o uso de conceitos de uma e outra na mesma análise), convém rever alguns aspectos essenciais para a compreensão desta última, aproximando-os de aspectos relevantes e essenciais à compreensão da primeira. 
Para a gramática gerativa-transformacional, a boa formação da sentença em termos sintáticos é o que decide se tal sentença pertence ou não à língua. No entanto, falantes concretos consideram as sentenças que emitem como bem formadas apenas por tornarem possível a interação pela linguagem. Os lingüistas começaram então a perceber e admitir Lakoff (1968) e Leech (1983), por exemplo - que o conceito de boa formação depende de fatores extralingüísticos em inúmeros casos. O conceito de competência discursiva de Maingueneau aproxima-se desta tendência.

A questão da boa/má formação das sentenças e a questão da pressuposição abrem definitivamente as portas para o desenvolvimento da pragmática, disciplina que se propõe a estudá-las sob novo enfoque, um enfoque que nasce do crescente interesse em se enxergar a língua como uma língua de falantes, e não apenas como um sistema lógico abstrato.

Hoje aceita como parte integrante da lingüística, a pragmática estuda a língua inserida em um mundo de usuários dessa língua. Este mundo de usuários falantes é na verdade a condição de existência da pragmática.

Mey (1993) propõe a seguinte definição de pragmática (consciente das dificuldades que há em obter-se um efetivo consenso sobre uma certa definição): a linguagem é o meio mais importante através do qual as pessoas se comunicam. O uso da linguagem para os mais variados fins é condicionado pelo contexto social, visto que é ele que oferece as condições de acesso e controle do recurso da linguagem. Assim, a pragmática é o estudo das condições de uso da linguagem, vistas como determinadas pelo contexto social. De fato, a expressão contexto social aqui se refere ao que Mey denomina contexto societal ("societal context"). Mey distingue entre um contexto social e um contexto societal para caracterizar, na segunda expressão, o sentido de responsabilidade individual inerente à formação da sociedade, que, segundo ele:

[...] não é trabalho do indivíduo, mas o indivíduo é responsável por isso na medida em que é um agente, um personagem, uma voz naquilo que Bakhtin chamou de orquestração de um texto. [...] O que vimos até agora pode ser então resumido da seguinte forma: as vozes dos humanos são os instrumentos constitutivos sobre os quais se funda, em última instância, a orquestração da sociedade. Como 
personagens sociais e agentes, os humanos "inventam" e estruturam a maneira como querem viver, mas também estão sujeitos às suas próprias criações, ou seja, a estrutura dá o troco ... [...] A formação social não é pois nem o trabalho de seres humanos individuais, nem exclusivamente o efeito de algumas macrocondições (econômicas, políticas, ecológicas etc.) que estão em funcionamento ao longo do tempo e do espaço. (p. 27)

Uma boa definição de pragmática depende de uma delimitação clara de suas fronteiras, o que até o momento, segundo Mey, não se conseguiu estabelecer satisfatoriamente. Leech (apud Mey, 1993) sugere que pragmática e semântica (a disciplina mais próxima) se complementem na prática, embora continuem sendo disciplinas distintas.

Na segunda observação importante, Mey considera que a pragmática teria princípios e não regras, pois as regras operam rigidamente no abstrato e os princípios estão voltados para o plano concreto de uso da língua. Além disso, a noção de regra contém implícita a noção de que é possível prever uma ocorrência lingüística, que se repetiria sempre, o que não é de fato o que ocorre com a língua em uso. Este ponto nos remete a Maingueneau (1984), em que o autor prefere utilizar o termo "hipótese" para remeter a princípios constitutivos do discurso. De forma paralela, fica explicitada em ambos os casos a abertura que os autores buscam para caracterizar linguagem e discurso dinamicamente.

O primeiro princípio, segundo Mey, é o princípio geral da comunicação, pois comunicar é o impulso inicial que leva os falantes a colocarem a língua em uso. O que não significa que todo falante de fato comunica o que quer ou pensa que quer comunicar. E esta questão também não tem nada a ver com o respeito a regras gramaticais. Segundo Leech (apud Mey, 1993), os falantes em geral fazem significar mais do que dizem de fato, enquanto outras vezes, inconsciente ou subconscientemente, expressam pensamentos e sentimentos que conscientemente prefeririam omitir. Assim entra-se na questão das chamadas implicaturas conversacionais, cujo estudo sistemático tem revelado os princípios mais importantes da língua vista da perspectiva pragmática. A questão do implícito chama a atenção da $\mathrm{AD}$ e é seu objeto de interesse, embora para a AD e para a semântica global não se aborde a questão do ponto de vista da consciência do indivíduo, ou de suas intenções, 
preferindo-se falar em coerções que determinam o que dizer e o que não dizer em função de determinada formação discursiva.

Os princípios centrais delineados pela pragmática são: o princípio da cooperação, trabalhado por Grice (1975); e a metáfora, entendida como um poderoso princípio de manifestação da linguagem e, como tudo na língua, dependente do contexto para que tenha a máxima expressividade. As metáforas, no contexto adequado, são capazes de direcionar o entendimento e nublar outros sentidos. O perigo da metáfora é o de ser entendida sem crítica, literalmente. O uso contínuo de determinadas metáforas pelos seus usuários colabora para que tais outros sentidos se apaguem. É tarefa da pragmática “desconstruir” a metáfora, buscando uma volta contínua a suas origens. A análise do discurso em geral e a semântica global em particular também estão preocupadas com a desconstrução dos sentidos cristalizados em metáforas, que, em função desta cristalização promovida pelo uso, já não são mais percebidas como metáforas, o que escamoteia a percepção do Outro nos discursos.

Além dos princípios de Grice e da questão da metáfora, importa para a pragmática o princípio da boa educação (politeness), entendido como o que é adequado como uso da língua em determinado contexto sócio-histórico. Tal princípio se manifesta em formas lingüísticas convencionais de abarcar ou não determinados sentidos. Os gêneros instituídos possuem tal princípio fortemente marcado através do uso de fórmulas consagradas. A pragmática e a análise do discurso têm a preocupação de igualmente “desconstruir" tais fórmulas para que se possam revelar os sentidos profundos que motivam e perpassam a construção do texto, sentidos esses necessariamente atrelados a certas formações discursivas.

Os pragmáticos modernos colocam em cheque os princípios de Grice, ao levantar a questão: haveria de fato cooperação entre os usuários da língua? Se sim, por que e até que ponto? Nesse contexto, estuda-se o que se chama em inglês de losing face, ao pé da letra, “perdendo a face”. Tal expressão refere-se à necessidade que os usuários da língua possuem 
de se proteger em certas situações de interação, o que põe em dúvida, ou ao menos limita, a presença da cooperação nessas situações.

As dúvidas quanto ao princípio de cooperação trazem à discussão, da perspectiva da $\mathrm{AD}$, a questão das coerções discursivas, neste caso das coerções genéricas propriamente, responsáveis por adequar o discurso à ação social e comunicativa em desenvolvimento, neutralizando ou minimizando ocorrências em que o sujeito do discurso "perde a face”.

Mey distingue entre o que chama de micropragmática e macropragmática. Sem esquecer o contexto, a micropragmática seria uma pragmática mais voltada à matéria lingüística. Mey chama de micropragmática ao estudo dos seguintes pontos, tradicionalmente estudados de forma dispersa pela semântica e pela pragmática em suas origens (Austin e Searle): referência e implicatura; atos de fala; verbos dos atos de fala; atos de fala indiretos; e a classificação dos atos de fala.

De acordo com o que dissemos acima sobre a semântica global, podemos dizer que, a seu modo, tal semântica também pressupõe uma bipartição em seus estudos, na medida em que, a partir do conceito de cena enunciativa, abarca no conceito de cena genérica os estudos ligados a discurso e no de cenografia os ligados à materialidade lingüística ou intradiscurso.

Neste ponto, interessa-nos em especial a questão da referência (uma vez que se constitui em item da análise), que é vista pela pragmática como algo contextual. Os dêiticos, por exemplo, mostram bem esta questão. Um "eu” dito em certo enunciado em determinada situação de enunciação irá se referir a uma certa pessoa e não a outra. Por sua vez, a anáfora (também categoria em análise neste trabalho), depende igualmente do contexto. O chamado antecedente que explicitaria aquilo a que a anáfora se refere (um nome, um trecho de texto, uma situação) importa do ponto de vista pragmático principalmente em função da “dimensão escondida” que toda referência anafórica embute. Isto quer dizer que a pragmática vai buscar na anáfora aquilo que constitui um valor, um julgamento, que muitas vezes é cultural, como é o caso, para citar um exemplo conhecido, do predomínio do masculino generalizante em certas línguas latinas, como o português. 
Podemos dizer que referência e anáfora são matéria de estudo da pragmática, ou de uma pragmática social (como prefere Mey), de uma forma que se aproxima da semântica global. Para a semântica global, tais aspectos lingüísticos (expressos em uma cenografia) apontam para o contexto da enunciação (que corresponde, para Maingueneau, à cena da enunciação). No caso da petição, o uso de determinados lexemas como referência anafórica só pode ser compreendido em toda a sua extensão se se mantiver a perspectiva da cena da enunciação em mente. Cena e contexto da enunciação podem ser vistos como conceitos paralelos, modos próximos de olhar para um mesmo fenômeno.

A implicatura conversacional, assim, está muitas vezes por trás de certos usos anafóricos, e pode ser apreendida graças ao instrumental da pragmática e da semântica global, em seus pontos de cruzamento.

Há também as implicaturas convencionais (os pressupostos, conforme Ducrot), que levam o interlocutor a concluir invariavelmente em uma certa direção. Mas é preciso ter em vista o que determina esta direção, ou seja, por que certa implicatura é convencional. Esta é também tarefa tanto da pragmática como da semântica global. A semântica argumentativa de Ducrot, que se desenvolve no bojo da pragmática, apresenta valioso instrumental para a análise lingüístico-discursiva dos implícitos. Seus conceitos de polifonia e direção argumentativa são úteis para a apreensão da interdiscursividade constitutiva dos gêneros analisados, e é por esta razão que tal instrumental teórico não poderia deixar de ser utilizado neste trabalho.

Um dos objetivos da pragmática, como disciplina independente dentro da lingüística, é acabar com a tradicional divisão que há entre lingüística teórica e lingüística aplicada. A primeira, muitas vezes, é vista como a “verdadeira” lingüística, ao que Mey responde com uma advertência aos lingüistas teóricos: eles deviam prestar mais atenção ao que os usuários da língua de fato fazem com ela. A pragmática e demais disciplinas abertas à questão do discurso e à questão do uso que os falantes fazem da língua ainda irão lutar muito para mudar o senso comum de que certas questões são periféricas e outras centrais no 
campo da lingüística. Para o analista do discurso, esta visão é fundamental, uma vez que seu trabalho só se desenvolve e se justifica na interação incessante entre teoria e análise da prática discursiva.

Mey afirma que os usuários da língua precisam ser “descobertos” pelos lingüistas, e mais, precisam ser inseridos em seu contexto social. O contexto é visto aqui não apenas como a base de desenvolvimento para a atividade de uso da língua, mas como o fator condicionante fundamental para tornar tal atividade possível. A definição de contexto em pragmática é em si imprecisa. O conceito de cena da enunciação (ou cena enunciativa) de Maingueneau, por seu lado, embora se articule no bojo da $\mathrm{AD}$, é fundamental na direção de uma maior precisão e pode contribuir para delimitar e esclarecer o contexto da perspectiva pragmática.

O que particularmente nos interessa na pragmática é o fato de considerar a linguagem ao mesmo tempo memória das ações (na medida em que as reflete) e guia das ações, na medida em que é capaz de recriar a realidade através dessas ações. Assim, a linguagem é a consciência prática das ações, que diz o que se está fazendo; e ao mesmo tempo, segundo Mey, um instrumento de planejamento, dizendo o que fazer. Qualquer esforço para melhorar o mundo deve envolver, em níveis distintos, uma consciência das condições sob as quais se vive enquanto seres humanos usuários de uma língua. Essa consciência passa necessariamente pela linguagem.

\subsubsection{Polifonia, interdiscurso, intertexto}

Como pano de fundo à análise lingüístico-discursiva, está, então, a pragmática e sua noção geral que preconiza a relação indissolúvel entre língua e falante, de acordo com a definição que dela fazem dois de seus autores principais: Levinson (1983) e Mey (1993, 2001). Austin, como um dos precursores da pragmática, oferece-nos a base teórica inicial e fundamental, pois, ao distinguir nos enunciados os elementos que atestam sua performatividade, ampara nossa pesquisa que entende o sujeito do discurso como parte e produto de um processo social pelo qual assume responsabilidade histórica. 
Nesse aspecto, o diálogo com a semântica global apresenta-se igualmente produtivo, pois, ao contrário de outros analistas do discurso, Maingueneau não considera o sujeito como mero reprodutor das formações discursivas às quais se alinha, mas sim como sujeito capaz de, em diferentes medidas, apropriar-se da própria voz e atuar na construção dos seus discursos, imprimindo-lhes direção.

A semântica argumentativa de Ducrot (1977, 1981 e 1987), inserida em uma perspectiva pragmática de linguagem, será especialmente aplicada aqui, como já dissemos, em função de dois conceitos chave: o de polifonia e o de direção argumentativa, que contribuem para mostrar, no texto, os caminhos interdiscursivos da voz do trabalhador.

Compreendemos que o texto jurídico trabalhista não escapa à argumentatividade constitutiva da linguagem (segundo acepção de Ducrot), embora sua aparente homogeneidade - produto de estratégias discursivas próprias do discurso jurídico - faça crer ao leitor menos treinado não existir embate explícito entre vozes e, portanto, “ausência” de interdiscursividade. De fato, para a devida apreensão deste embate e do jogo interdiscursivo, não basta analisar a petição em si. É preciso levantar e analisar os processos de retextualização por que passa o discurso falado no contexto de produção do discurso jurídico trabalhista escrito, modalidade esta com estatuto legal. O estudo das atividades de retextualização do oral para o escrito no processo de construção dos textos com valor legal nos possibilitará observar o percurso da voz do trabalhador de uma modalidade a outra, o embate que trava com outras vozes e como se dá o seu quase apagamento nos textos oficiais finais. Os estudos de Marcuschi (1986, 1995, 2000 e 2001) sobre atividades de retextualização nos trarão a base teórica nesta etapa da pesquisa.

Esclarecemos a seguir o conceito de polifonia de Ducrot (1987), procurando relacioná-lo aos conceitos de interdiscurso e intertexto.

Em seu texto Esboço de uma teoria polifônica da enunciação, parte do livro $O$ dizer e o dito (1987), Ducrot afirma ser seu objetivo impugnar o mito da unidade do sujeito falante. Identifica-se com o trabalho de Authier sobre heterogeneidade discursiva e considera sua teoria polifônica como uma extensão livre dos trabalhos de Bakhtin sobre polifonia na literatura. O trabalho de Ducrot destaca-se da tradição da pragmática de Austin e Searle 
porque seu interesse não está em refletir sobre o que se faz ao falar, mas sim no que a fala faz segundo um enunciado. Para Ducrot, qualificar a enunciação de um enunciado é obter o sentido do mesmo. Neste ponto, podemos apontar uma convergência de propósitos entre a teoria de Ducrot e a semântica global, uma vez que, para Maingueneau, assim como para a AD em geral, o perfil da enunciação, configurado na cena enunciativa, corresponde ao sentido do enunciado.

Para Ducrot, assim como para a $\mathrm{AD}$ e para a semântica global, a enunciação é um acontecimento histórico constituído pela aparição do enunciado. Tal definição exclui a noção de sujeito falante, ao contrário do que entende a pragmática em geral. No entanto, Ducrot deixa claro que esta exclusão é fruto de uma decisão metodológica, que possibilitasse a construção de uma teoria do sentido independente, e não fruto da crença em um sujeito falante omisso. Voltaremos a este ponto mais adiante.

Para Ducrot, a comunicação se desdobra em dois níveis: por um lado, o sujeito realiza atos de fala para estabelecer um ato jurídico (que implica, no tempo e espaço do discurso e fora dele, o estabelecimento de vínculos e compromissos sociais); por outro, o sujeito comunica um saber sobre sua própria enunciação. Esse saber enunciativo está expresso na argumentação constitutiva da linguagem, daí ser a argumentação uma maneira pela qual o sentido representa a enunciação, e não elemento exterior a ela.

O sentido do enunciado (descrição de sua enunciação) é apreendido secundariamente pelas indicações argumentativas e ilocutórias e fundamentalmente pelas informações que o enunciado porta sobre o(s) autor(es) eventual(ais) da enunciação. E aqui não se trata de um autor empírico (conforme sua metodologia), mas da figura discursiva a que Ducrot denomina locutor. Locutor, segundo esta concepção, que é a que nos interessa, é aquele que o enunciado porta como autor (e que não corresponde necessariamente ao falante empírico). O locutor é aquele que, no enunciado, se autodenomina EU, e se apresenta como um dos enunciadores do texto (conforme definição de “enunciador” abaixo).

O locutor não fala sozinho no enunciado. Alterna pontos de vista, de modo mais ou menos explícito. Neste ponto pode-se falar na presença do OUTRO no discurso, representado por 
tais vozes que se aliam ou não à voz central, a voz do locutor. A essas vozes, Ducrot chama de enunciadores, palpáveis na superfície do discurso por marcas lingüísticas.

O que nos interessa aqui de modo particular é o fato de que tais marcas não podem ser apreendidas por si sós, sem que se empreenda a necessária relação entre a superfície discursiva, em que os aspectos estritamente lingüísticos saltam aos olhos mais imediatamente (ou não), e os demais níveis discursivos, ou seja, as três cenas que compõem a cena enunciativa. Observar as marcas lingüísticas que se articulam numa dada cenografia, relacionando-as ao gênero ao qual pertence o texto e ao campo discursivo no qual foi produzido, é condição para a máxima apreensão do sentido.

Ducrot compara sua concepção de locutor x autor à teoria de Genette (1972) sobre a diferença entre narrador e autor. Grosso modo, o enunciador estaria para o locutor, assim como o personagem estaria para o narrador. O locutor faz de sua enunciação uma espécie de teatro, em que se dá a palavra a vários personagens (enunciadores). A noção de ato de linguagem é, assim, profundamente ampliada, pois, se diferentes enunciadores constroem a fala, constituindo-a como polifônica, o ato de linguagem não pode ser linear, nem homogêneo, mas sim entrecruzado desde o início pela fala do OUTRO e a partir dela formado.

\subsubsection{Direção argumentativa: fenômeno de construção lingüística de direitos e deveres sociais}

Para compreendermos o fenômeno da construção lingüística de direitos e deveres sociais, é preciso, antes de tudo, esclarecer devidamente a noção de sujeito que nos interessa.

Evidentemente, direitos e deveres não se constroem por si, são construídos por sujeitos que interagem socialmente e negociam (na e pela linguagem) suas regras de convivência. A própria noção de responsabilidade social não pode ser compreendida se não houver um sujeito responsável. Assim sendo, o sujeito do discurso que nos interessa aqui é aquele que, ao dizer EU, toma para si a responsabilidade pelo que diz. Ao dizer EU, o sujeito é simultaneamente interpelado em sujeito do discurso (e, portanto, submetido às coerções correspondentes, conforme tradicionalmente coloca a $\mathrm{AD}$ ) e em sujeito de uma ação que 
terá repercussões no discurso e para além dele. Embora se trate de um sujeito histórico, clivado por diferentes vozes, cuja fala só existe dialogicamente (há os outros a quem efetivamente a fala é dirigida e os outros de que tal fala é desde-já constituída) - o que significa que o sujeito só adquire identidade na relação com o outro -, o ato de dizer EU não é inconseqüente, suas repercussões não se esgotam no espaço discursivo criado entre EU e TU.

O sujeito que nos interessa diz o que pode e deve ser dito, reproduzindo, graças à memória discursiva, os elementos que caracterizam sua filiação à determinada formação discursiva (que, como vimos, não é homogênea). Ao mesmo tempo, como toda formação discursiva precisa constantemente arejar-se para coexistir e apropriar-se de seus outros, o sujeito pode dizer algo não previsto, ou não permitido, conforme sua competência de dialogar com os elementos constitutivos de sua formação. Isto tal sujeito realiza materialmente através da construção da cenografia. A cenografia discursiva pode ser vista como o espaço de liberdade relativa do sujeito do discurso. Ao criar a cenografia, o sujeito consolida-se não só como sujeito do discurso, mas também como sujeito que interfere, que aponta, que atua. Inferimos que é através do novo que se imiscui a partir da cenografia, que a mudança é possível, podendo atingir os níveis dos gêneros e campos discursivos.

Acrescentamos ainda que só se pode falar em Direito, incluindo o direito trabalhista, se se admite a existência de um sujeito responsável, que é, na prática social e legal, o chamado sujeito de direito. É motivo de discussão nesta tese, como se verá, as implicações da não atribuição a si mesmo do pronome EU por parte do trabalhador. Quem é então o sujeito de direito? Como se atribuem direitos e deveres a um sujeito que não se autodesigna EU? Em que medida a direção argumentativa é afetada se é OUTRO que se designa EU? Como diz Ricoeur (1995:31). “[...] la capacité d’un agent humain à se designer lui-même comme l'auteur de sés actes a une signification considérable pour l'assignation ultérieure de droits et de devoirs"16.

16 ... a capacidade de um agente humano a se designar ele próprio como o autor de seus atos tem uma significação considerável para a citação posterior de direitos e de deveres.” 
Neste trabalho, consideramos o fenômeno lingüístico da direção (ou orientação) argumentativa, conforme proposto por Ducrot (1981), como elemento central de construção de cenografia. A argumentatividade própria à língua aliada à direção que o sujeito de discurso responsável imprime à fala (direção esta apoiada na argumentatividade intrínseca à língua) constituem-se a prática lingüístico-discursiva (e cenográfica) que constrói na linguagem direitos e deveres sociais. Conforme nos diz Vogt (1989):

Há, assim, na língua, mais do que a inocência da informação. Como observa Ducrot, mais do que condição de vida social, a língua se apresenta como poderoso determinante do modo de vida social, como uma espécie de tratado dos deveres, espécie de atividade jurídica cujas regras, explícitas ou implícitas, envolvem o homem, como teia sutil de subentendidos e pressupostos, submetendo-o a um incessante confronto de subjetividades, constante do jogo de intenções onde a aposta menor é o risco de comprometer-se.

Se a língua é, como pretende o idealismo de Chomsky, o espaço mesmo em que reside a liberdade do homem, a sua capacidade criativa, é preciso convir, no entanto, que esta liberdade está constantemente ameaçada pelo jogo sutil da palavra.

O risco de falar é a ameaça de tornar-se prisioneiro de sua própria liberdade.

Observe-se que, a partir de um certo ponto da citação, Vogt apresenta o estabelecimento pela língua dos direitos e deveres sociais como fator de cerceamento à liberdade individual. A nosso ver, a tensão indivíduo x sociedade, ou, em nossos termos, o embate constante entre EU X OUTRO no discurso, não significa necessariamente cerceamento do EU. O indivíduo que, enquanto sujeito de discurso, entra no jogo da linguagem e aceita o risco de comprometer-se não perde sua liberdade, mas a (re)adquire em nova base: a que implica constante negociação entre subjetividades. O aprisionamento está na impossibilidade de autocategorizar-se EU em discurso e não poder negociar. O último parágrafo da citação, no entanto, reorienta sua interpretação, fazendo-nos entrever a polifonia de que se constitui a própria língua: ser prisioneiro da própria liberdade (e da própria língua) pode ser algo positivo, pode significar ser de fato livre, se se tiver em vista uma liberdade menos idealizada, mas uma liberdade suficiente para abarcar o nível dos homens em relação.

Esta tese constrói-se, assim, a partir dessa noção geral e norteadora de linguagem que não exclui de sua definição sua vocação de construtora social, imbuída de um sujeito não autônomo, mas responsável pela sua fala. O sujeito do discurso, que constrói sua cenografia 
tendo em vista determinada direção argumentativa, desencadeia transformações que extrapolam o nível lingüístico-discursivo (que é evidentemente afetado por elas). Ao tratarmos de como se dá lingüisticamente a defesa dos interesses dos trabalhadores através das petições trabalhistas, nada mais fazemos do que atestar tal vocação.

Neste ponto, importa esclarecer que o conceito de argumentatividade conforme desenvolvido por Anscombre/Ducrot (1983), e que é o que nos interessa aqui, não pode ser confundido com a noção de argumentação desenvolvida pelos estudos retóricos. Vejamos, inicialmente, o que, para nós, argumentatividade não é:

Defender explicitamente um ponto de vista: esta visão usual é apenas parcialmente correta. De fato, cada vez menos se pode falar em uma linguagem centralmente referencial, espelho do mundo, neutra e idealizada. Cada vez mais observa-se que o que se vê e se retrata na e pela linguagem são menos objetos do mundo e mais frutos de olhares determinados em boa medida por certa cultura em dado momento sócio-histórico. O viés cultural, no qual se insere o individual, recorta, modela e recria o objeto do mundo. Assim sendo, ao se defender um ponto de vista, não se está pondo em questão o que é verdadeiro e o que é falso; o que se faz é procurar consolidar um recorte da realidade, que será mais ou menos válido para o grupo em que se instala o embate quanto mais ou menos a argumentação caminhar na direção dos interesses desse mesmo grupo, ou de sua maioria. É equivocado atribuir ao termo argumentar o caráter de “defesa explícita” de um ponto de vista. Nesta acepção, a linguagem só assumiria sua função argumentativa em situações bastante específicas: em debates de todo tipo, discursos de personalidades, editoriais de jornais, etc.

Este equívoco tem levado à consolidação de gêneros ditos argumentativos em oposição a outros que não apresentariam tal especificidade. É o que a Escola faz ao ensinar, por exemplo, que o editorial de jornal é texto argumentativo, enquanto os textos poéticos não o seriam. Engano, pois a argumentatividade é intrínseca à linguagem, mesmo em suas formas ou gêneros mais corriqueiros. Ao se dizer "bom dia” ao encontrar um vizinho pela manhã, podemos estar argumentando favoravelmente à política da boa vizinhança, ou à valorização dos hábitos sociais básicos referentes à boa educação. Ao não dizer "bom dia”, poderemos estar argumentando em outra direção, favorável, por exemplo, à ruptura de padrões básicos em prol do que se considera boa educação, ou mesmo a favor da quebra de certo tipo de 
relação de cordialidade convencional, mecanizada. Enfim, imprimimos uma direção argumentativa aos nossos enunciados mais simples, em qualquer situação, direção essa que nem sempre é explícita.

Ocorre que a existência da direção argumentativa independe do seu grau de explicitude. Ao contrário, muitas vezes o estar implícita é o que lhe imprime maior força, como ocorre nos casos em que o silêncio substitui vantajosamente a palavra.

Estabelecer um embate lingüístico com o objetivo de obter ganho pessoal: o embate discursivo não se dá entre falantes autônomos e auto-suficientes, homogêneos em si mesmos, em defesa de interesses meramente pessoais. O que se diz não se diz sozinho. A originalidade está muito mais em como se criam as condições para se dizer o que se diz (construção da cenografia) do que propriamente no que se diz. A ilusão de um sujeito homogêneo e plenamente distinto dos demais inibe a percepção de que a direção argumentativa que se imprime aos enunciados tem caráter fortemente social, cultural e ideológico. No dia-a-dia a consciência de que esta limitação existe e de qual seria sua especificidade escapa ao falante comum. E é este "esquecimento" que fluidifica e favorece as trocas lingüísticas, que dificilmente ocorrem em níveis meramente informativos. $\mathrm{O}$ falante assim, ao tomar a palavra, fala de um lugar que é apenas parcialmente o lugar individual. Sua visão de mundo determinada sócio-historicamente dá a direção predominante.

Importa frisar que não se trata de afirmar que o falante não cria de forma alguma sua própria fala, até porque isto significaria isentá-lo de suas responsabilidades enquanto falante. Basta lembrar do conceito de cena da enunciação e de como é possível construir cenografias diversas que podem influenciar significativamente a própria cena genérica que lhe seria típica e, eventualmente, até mesmo a cena englobante. Trata-se de verificar que os interesses pessoais que emergem na argumentação significam interesses mais gerais e que a unidade expressa pela força argumentativa traz implícita a polifonia devidamente orquestrada de vozes mais ou menos dissonantes, enunciadoras desse opaco "grupo social geral”, introjetado no sujeito, sempre na direção de determinadas conclusões, que visam a determinados interesses e não a outros. 
Ao se observar o fenômeno lingüístico da direção argumentativa como elemento que constrói na linguagem direitos e deveres sociais, considera-se que, na vida social em seus mais diversos níveis, ocorre o constante embate (nem sempre explícito) de idéias de grupos mais ou menos divergentes, inseridos em uma história no mais das vezes comum, assemelhados por um tempo social também comum, que provê para tais grupos a criação, manutenção e perpetuação de seus interesses. A linguagem estaria promovendo, assim, através do fenômeno da argumentatividade, sua função de construtora social. Ao se estabelecerem pela linguagem os limites entre grupos, estabelecem-se igualmente compromissos entre eles; emergem os direitos e deveres, continuamente negociados na e pela linguagem, já que o jogo não tem fim.

A nosso ver, não existem gêneros argumentativos. Claro que, de acordo com a tipologia textual de Adam (1992), pode-se falar em argumentação como um tipo específico, prototípico, de construção textual, encontrada em diversos gêneros. Mas não é deste tipo de argumentação que estamos tratando aqui. A noção de argumentatividade desenvolvida por Anscombre/Ducrot é constitutiva da linguagem.

Todo ato de fala traz uma direção argumentativa nele imbricada. Como dissemos, a argumentatividade, assim como sua direção, não é externa ao ato, mas constitutiva desse ato. O falante pode, muitas vezes, embora responsável por sua fala, não ter a exata noção do impacto dos atos que produz (justamente em função da argumentatividade constitutiva), mas pode percebê-lo pela recepção da sua fala e pelos atos de fala que receberá como resposta. Assim, a fala se constrói dialogicamente, moldando e sendo moldada pelo discurso em que está inserida, e construindo relações que serão necessariamente regradas socialmente. Como diz Souza Filho (1983):

Enquanto ação, o ato de fala realiza-se num contexto de valores e normas, papéis e instituições, regras e convenções estabelecidos socialmente. Estes elementos, porém, não são invariáveis, mas mudam constantemente conforme as condições históricas da sociedade que os produz, pois resultam destes processos sociais. [...] Deste modo, pode-se dizer que linguagem e sociedade encontram-se numa relação de interdependência. Diferentes estruturas de relações sociais determinam a formação de diferentes contextos de interação e de diferentes formas de uso 
lingüístico e de distribuição de papéis aos falantes. Por outro lado, a linguagem forma o horizonte que condiciona a experiência que os indivíduos têm da realidade e neste sentido é constitutiva da realidade. (p. 30)

Ao que afirma o autor, acrescentemos que, como sujeitos de discurso responsáveis, os indivíduos podem ou não acatar certos papéis, podem ou não atribuí-los de tal ou tal forma, contribuindo com sua experiência única para a transformação das formas de interdependência da relação linguagem e sociedade.

Esta constante negociação que se dá na e pela língua revela a dinamicidade da linguagem, sua rica relação com a vida mesma, em toda a sua heterogeneidade. O discurso jurídico, no qual se inclui o trabalhista, embora tenda à homogeneidade, é um exemplo claro de construção deste embate, deste estabelecimento constante de regras que regulam a sociedade e a vida dos indivíduos.

\subsection{Retextualização, intertexto e interdiscurso}

Os discursos, constituídos interdiscursivamente, são sempre dinâmicos e sujeitos a transformações. Tais transformações são mais ou menos lentas, na medida da abertura que o discurso em pauta possui para o OUTRO, para o novo.

Os diferentes gêneros que compõem um discurso e marcam sua interdiscursividade também apresentam graus variados de abertura para o OUTRO. Os gêneros mais fechados, mais homogêneos em sua superfície discursiva - como as petições trabalhistas - podem ser mais bem analisados em suas marcas interdiscursivas (polifônicas) se pudermos ampliar o foco da análise e abarcar no estudo os gêneros que muitas vezes os antecedem e que dirigem parte da sua construção.

A petição, embora possua um "formato" consolidado que a remete ao interdiscurso do Direito enquanto instituição, que tende a perpetuar e justificar esse mesmo formato, possui também as marcas da interação trabalhador-advogado, que dá origem às petições específicas (textos específicos). Tais marcas fluidificam o gênero petição, pois mostram as especificidades da relação entre sujeitos que representam, ao mesmo tempo, sujeitos de um discurso institucional e sujeitos submetidos a idiossincrasias de outros campos e formações 
discursivas, o que alimenta o gênero com o que é novo, incorporando-o, de certa forma, ao que já está consolidado. Daí não haver duas petições iguais.

Por isso argumentamos que a entrevista inicial entre o trabalhador reclamante e o advogado que irá defender sua causa traz, enquanto gênero, elementos que elucidam a construção da petição e possibilitam a apreensão de interdiscursos dificilmente apreensíveis apenas na análise da petição. Os gêneros de um discurso constroem-se uns aos outros e a percepção de suas especificidades, relacionadas entre si, ampliam as possibilidades de apreensão dos interdiscursos.

No caso da entrevista inicial trabalhador-advogado e da petição que é redigida após tal entrevista, as marcas efetivamente textuais que atestam que o segundo texto se originou do anterior (marcas intertextuais) são poucas. De fato, de tal forma a fala se transforma do primeiro ao segundo gênero, devido às coerções deste segundo, que pouco resta da textualidade do primeiro. No entanto, de um ponto de vista (inter)discursivo, podem-se estabelecer as relações.

Chamamos de retextualização ao processo de transformação de um texto a outro, apropriando-nos do conceito conforme o desenvolveu Marcuschi (2001), com as devidas adaptações, uma vez que não se trata diretamente de descrever os movimentos que transformam um texto oral em escrito, mas os movimentos (motivados discursivamente) que transformam um texto de um gênero (seja ele oral ou escrito) a texto de outro gênero, em princípio num mesmo campo discursivo.

\subsection{Retextualização e direção argumentativa}

Como já mencionado, o conceito de retextualização que adotaremos nesta pesquisa é o de Marcuschi (2001). Segundo o autor, é preciso entender que há uma enorme diferença entre transcodificação (que é a tentativa de passagem direta do sonoro para o gráfico) e retextualização, que é a passagem do oral para o escrito que implica complexo processo de transformações entre códigos, sujeitas a interpretações e postas em prática objetivando não apenas a uma mera "tradução" do oral para o escrito, mas especialmente, e sobretudo, à construção de uma determinada direção argumentativa. A tarefa de retextualização não é 
algo simples, natural ou neutro. Segundo Marcuschi (2001), "trata-se de uma atividade que atinge de modo bastante acentuado a fala original e pode ir de um patamar elementar até uma interferência muito grande".

Em nossa pesquisa, tratamos de analisar as operações textual-discursivas na passagem do texto oral para o escrito durante a produção do texto jurídico trabalhista, que implicam mudança de gênero. De início, tomamos como base as operações chave dessa passagem do oral ao escrito, identificadas por Marcuschi (2001), a saber:

1. Eliminação de marcas estritamente interacionais (estratégia de eliminação baseada na idealização lingüística).

2. Introdução da pontuação com base na intuição fornecida pela entoação (estratégia de inserção em que a primeira tentativa segue a sugestão da prosódia).

3. Retirada de repetições, reduplicações, redundâncias, paráfrases e pronomes egóticos (estratégia de eliminação para uma condensação lingüística).

4. Introdução da paragrafação e pontuação detalhada sem modificação da ordem dos tópicos discursivos (estratégia de inserção).

5. Introdução de marcas metalingüísticas para referenciação de ações e verbalização de contextos expressos por dêiticos (estratégia de reformulação objetivando explicitude).

6. Reconstrução de estruturas truncadas, concordâncias, reordenação sintática, encadeamentos (estratégia de reconstrução em função da norma escrita).

7. Tratamento estilístico com seleção de novas estruturas sintáticas e novas opções léxicas (estratégia de substituição visando a uma maior formalidade).

8. Reordenação tópica do texto e reorganização da seqüência argumentativa (estratégia de estruturação argumentativa).

9. Agrupamento de argumentos condensando as idéias (estratégia de condensação). 
Interessa-nos observar que cada operação não ocorre de forma automática ou padronizada, mas seguindo critérios intersubjetivos com vistas à construção de uma certa direção argumentativa, o que significa fazer valer prevalecer, de forma mais ou menos contraditória, determinados gêneros discursivos em detrimento de outros, de acordo com determinações do próprio discurso em análise (o jurídico trabalhista).

Neste ponto caberá averiguar como se constrói a interdiscursividade no processo de retextualização. Constatamos que não se trata simplesmente de processo que produz gêneros distintos e estanques e desloca a voz do sujeito da enunciação (construindo sujeitos diferentes em cada gênero), mas sim de processo mais complexo, que constrói níveis diferentes de intertextualidade e interdiscursividade. Há, portanto, um diálogo que se mantém no processo jurídico trabalhista inteiro. Neste trabalho, procuraremos alinhavar a natureza lingüístico-discursiva deste diálogo.

\subsection{Referenciação e construção de sentido}

Segundo Maingueneau (2001), os locutores de uma língua possuem diversos modos de referenciação ou apresentação do referente. Nesta tese, preferimos falar de construção do referente. Basicamente, para sua apreensão, o co-enunciador recorre a sua competência enciclopédica e/ou ao ambiente da enunciação. Ao enunciador cabe, através do enunciado, passar as instruções necessárias à identificação do referente. Nesta perspectiva, não é o enunciado que faz referência a algo: trata-se de uma construção conjunta enunciador - coenunciador.

As designações, ou modos de referenciar, ou ainda modos de apresentação do referente, podem ser de vários tipos: nomes próprios; substantivo (ou grupo nominal) com determinante definido; substantivo (ou grupo nominal) com determinante indefinido; substantivo (ou grupo nominal) com determinante demonstrativo; pronomes; e embreantes (conforme terminologia de Maingueneau) - ou dêiticos discursivos (cf. Levinson 1983) (que referenciam ou designam - ou constroem - o próprio contexto da enunciação). O que importa, nesta análise, é que o modo de designação não traduz uma escolha aleatória ou um 
gosto estilístico, mas sim uma escolha que produz sentido numa certa direção, e não noutra, de acordo com coerções genéricas. Voltaremos a este ponto durante a análise.

O grupo (ou expressão) nominal com determinante definido chama-se descrição definida. Em geral, seu uso equivale a um nome ou designa uma classe. É exatamente o que ocorre ao observarmos as descrições definidas mais utilizadas no gênero petição trabalhista: “o requerente” e “o reclamante”. Nos dois casos, a descrição substitui um nome próprio: o do trabalhador que move a causa trabalhista; e se refere simultaneamente à classe dos trabalhadores, já que tais descrições definidas são utilizadas indistintamente em todas as petições, independentemente de quem seja o autor da causa (o trabalhador), conforme nomenclatura usada no Direito.

Para Maingueneau, a descrição definida pode ser autônoma (o cotexto fornece as instruções necessárias para sua interpretação) ou dependente do contexto. Consideramos esta distinção difícil de se fazer na prática da análise textual, principalmente quando são analisados como um conjunto - textos diversos pertencentes a um mesmo ato enunciativo (que é o caso do processo trabalhista). Além de serem textos distintos, pertencem a gêneros diversos (embora todos submetidos à coerção do campo discursivo jurídico trabalhista), o que torna a distinção cotexto/contexto ainda mais problemática. O conceito de cotexto, nesse caso, deve ser ampliado, pois as instruções para interpretação podem estar em outro texto do processo. Ao mesmo tempo, o conceito de contexto - vago ou insuficiente - foi preterido em nossa análise e substituído pelo conceito de condições de produção do discurso (ou simplesmente CP), de Courtine (1981), que, admitindo as dificuldades para uma boa definição, considera as condições de produção do discurso como o conjunto das relações que se estabelecem entre os sujeitos de discurso e as formações discursivas que dominam uma seqüência discursiva.

O grupo (ou expressão) nominal com determinante demonstrativo tende a criar efeito de sentido de proximidade com o ato da enunciação e efeito de sentido de distinção em relação a outros referentes da mesma categoria. O grupo (ou expressão) nominal com determinante indefinido introduz novos referentes no discurso, que podem ou não ser especificados mais 
adiante no texto. O indefinido pode orientar uma interpretação específica, designando um objeto particular (virtual ou não), ou orientar uma interpretação genérica, apontando para uma classe. Nos textos analisados, em especial na petição trabalhista, não há tais usos, sendo de praxe a descrição definida, ou seja, uma expressão nominal regida por determinante definido. Não é de estranhar que assim seja, uma vez que os textos põem em evidência um referente que, de acordo com os pressupostos do Direito, é único e não pode ser confundido: trata-se do sujeito de direito trabalhador. Ocorre, no entanto, como veremos em nossa análise, que tal unicidade construída discursivamente traz em si as marcas de heterogeneidade e da interdiscursividade, como é próprio a todo discurso. Embora a enunciação se esforce para operar a construção discursiva conforme os pressupostos idealistas do Direito, os textos traem-se a si mesmos, possibilitando ao analista do discurso apreender a polifonia e as contradições próprias ao Direito Trabalhista e ao mundo do trabalho no Brasil.

Podemos dizer, enfim, que a apreensão adequada dos modos de apresentação do referente depende simultaneamente de aspectos pragmáticos, enunciativos/discursivos e de organização textual, que formam o quadro global dentro do qual se constrói sentido.

\section{A anáfora}

A referenciação através de grupos ou expressões nominais (que retomam outras unidades do cotexto) nos leva à questão da coesão, fenômeno que faz o texto progredir e principal recurso lingüístico para a construção da cenografia. Tais retomadas designam-se comumente por relação anafórica. Fala-se em anáfora quando o termo que retoma segue o termo retomado e de catáfora quando o termo que retoma antecede o termo retomado. Ambos os processos chamam-se endófora.

A função coesiva é uma importante função dos grupos ou expressões nominais, mas há outras: cognitiva, de organização textual, de sumarização e avaliativa (Koch: texto avulso, s/d). Para nós, a função coesiva vai além, pois, ao definir a coerência do texto, é responsável direta pelo seu sentido, adquirindo um valor discursivo-pragmático, não 
meramente lingüístico (ou intradiscursivo). Trata-se igualmente de recurso central para a construção da cenografia discursiva, portanto espaço de certa liberdade de construção do sentido por parte do locutor enunciador, responsável por construir a seqüência discursiva, ou intradiscurso. No entanto, em textos fortemente institucionalizados, como é o caso da petição trabalhista, o espaço de liberdade reduz-se ao mínimo, como se verá no caso da coesão construída com o recurso da anáfora feita através das descrições definidas do tipo “o recorrente” e “o reclamante”. A esse tipo de anáfora a lingüística textual chama de anáfora lexical, embora seja necessário frisar que empregamos o jargão lingüístico em sentido abrangente, por duas razões centrais:

1. Os lexemas escolhidos o são por razões de ordem discursivo-pragmáticas.

2. A apreensão adequada do antecedente não se dá buscando-o simplesmente no cotexto, mas sim nas condições de produção do discurso.

A anáfora, conforme Koch e Marcuschi (1998), implica progressiva construção de sentido, que não se dá sem o conhecimento das regras pragmáticas. Maingueneau (2001), por seu lado, não considera anafóricas as descrições definidas que demandam o conhecimento pragmático. Optamos pela posição de Koch e Marcuschi porque viabiliza uma análise com perspectiva lingüístico-discursiva $e$ pragmática, como a que segue.

A anáfora deve ser entendida como mecanismo de coesão que constrói sentido durante a produção textual. Ela não se limita a reproduzir o referente, mas o resignifica a cada ocorrência de grupo ou expressão nominal. A resignificação pode suscitar um efeito de sentido negativo ou positivo, colaborando para construir a direção argumentativa do texto. Durante a análise, procuraremos mostrar, no entanto, que a anáfora lexical construída por expressões como “o recorrente” e "o reclamante” traz em si as fortes marcas do discurso de que é produto (jurídico trabalhista) e do interdiscurso do mundo do trabalho. Assim, as anáforas lexicais “o recorrente” e "o reclamante”, usadas de forma sistemática, já surgem resignificadas por força do discurso de origem e do interdiscurso do mundo do trabalho. Dito de outro modo, tais anáforas possuem um significado institucional tão forte que sua 
ocorrência na superfície discursiva dá-se de forma cristalizada, com baixo potencial de resignificação durante a produção textual.

\section{Referenciação e gênero do discurso}

Os modos de apresentar o referente, ou seja, os processos de referenciação que imprimem coesão e coerência ao texto, não podem ser vistos, como já dissemos, apenas de uma perspectiva estritamente lingüística, que se satisfaz com os elementos palpáveis na materialidade horizontal do enunciado. Se referenciar implica (re)significar, e se o (re)significar exige por parte dos interlocutores sua inserção crítica no campo discursivo em que se dá a produção discursiva, cabe perguntar em que instância este (re)significar se torna palpável e passível de maior compreensão.

Courtine (1981), citando Foucault, diz que:

Le réfèrentiel de l'enoncé “forme le lieu, la condition, le champ d'emergence, l'instance de différenciation des individus ou des objets, des états de choses et des relations qui sont mises en jeu par l'enoncé lui-même. Il définit les possibilités d'apparition et de délimitation de ce qui donne à la phrase son sens, à la proposition sa valeur de véritée” [...]: c’est dans l'enoncé que se construit la stabilité référentielle dês éléments du savoir. (p. 42) ${ }^{17}$

De fato, o primeiro passo é compreender o enunciado como uma instância complexa, marcada pela interdiscursividade, cujas coerções definem a estabilidade do referente. Assim é que consideramos que a análise do gênero do discurso segundo o qual se dá a produção discursiva é decisiva para a apreensão do sentido. É na cena genérica que certos tipos de referenciação se tornam de fato compreensíveis. Assim sendo, um processo de referenciação ocorrido em determinado texto só poderá ser plenamente compreendido a partir da compreensão do significado social do gênero do discurso em pauta; de sua função como elemento de representação dos sujeitos de interlocução no processo de comunicação

\footnotetext{
${ }^{17} \mathrm{O}$ referencial do enunciado forma o lugar, a condição, o campo de emergência, a instância de diferenciação dos indivíduos ou dos objetos, dos estados de coisas e de relações que são colocados em jogo pelo próprio enunciado. Ele define as possibilidades de aparição e de delimitação do que dá à frase seu sentido, à proposta seu valor de verdade [...]: é no enunciado que se constrói a estabilidade referencial dos elementos do saber.
} 
como um todo; e ainda, em se tratando de um processo comunicativo envolvendo mais de um gênero, da relação discursivo-pragmática entre tais gêneros.

Tomando como exemplo o gênero petição trabalhista, observamos que a construção do sentido do sujeito de discurso trabalhador dá-se através de uma escolha lexical bastante específica, ou seja, da escolha de certas expressões referenciais definidas que não apenas referenciam anaforicamente o sujeito trabalhador, mas o constroem enquanto sujeito no discurso jurídico trabalhista a partir dos paradigmas desse discurso. O trabalhador deixa, assim, de ser trabalhador, deixa de ser referido pelo seu nome próprio, e passa a ocupar a categoria do sujeito pedinte de um direito, do sujeito que "solicita”, “pede” a instâncias do poder jurídico constituído. O ato ilocutório de pedir, nos moldes do discurso jurídico trabalhista, só pode ser realizado com sucesso através da petição. Nenhum outro gênero do discurso cumpre tal função social. Da mesma forma, nenhum outro gênero constrói a posição de trabalhador da forma necessária e exigida pelas instâncias reguladoras do discurso, ou seja, de seu sistema de restrições semânticas. Ao construir o sujeito trabalhador de uma determinada forma, as coerções genéricas nada mais fazem do que representar tal sujeito de acordo com tais coerções. Assim é que o sujeito discursivo trabalhador deixa de sê-lo para constituir-se em sujeito discursivo requerente (ou reclamante, ou expressão anafórica similar), sob pena de não ver atendida sua solicitação.

Interessa observar que o sujeito discursivo trabalhador não constrói sua posição por si, não é ele que se representa no discurso da forma convencional e necessária, mas é construído e representado pelo sujeito discursivo advogado, este sim, juntamente com a figura discursiva do juiz, constitutivo do par interlocutivo EU X TU, ambos sujeitos depositários do saber jurídico.

Finalmente, as representações ou posições de sujeito construídas em cada gênero de um mesmo processo de comunicação (como é o caso do processo jurídico trabalhista) só podem ser plenamente compreendidas observando-se como tais diferentes representações de sujeito se inter-relacionam no discurso. 
A referenciação vista de forma estritamente lingüística não pode dar conta de mostrar o nível de representatividade discursiva dos sujeitos envolvidos. É preciso observar o gênero do discurso, que amplia o sentido construído e faz ver os níveis de representatividade de forma abrangente. Em especial nos textos institucionalizados, a não observância criteriosa do gênero leva necessariamente a perdas na apreensão dos sentidos produzidos. O enunciado produzido a partir de uma certa cena genérica traz uma representação de sujeito determinada pela posição que tal sujeito pode e deve ocupar.

\subsection{Tempo, transform(ação) e sentido}

Memória e ação do orador eram duas das cinco partes das quais se compunham os gêneros deliberativo, judiciário e epidítico, divisão clássica dos gêneros do discurso proposta pela retórica antiga (que se distinguiam por se articularem internamente com vistas respectivamente ao futuro, ao passado e ao presente). Segundo Petri (1988), após esse período, tais instâncias discursivas não receberam o tratamento devido. Muito mais tarde, a $\mathrm{AD}$ se ocuparia tangencialmente da questão da memória, desenvolvendo o conceito de memória discursiva, que se distingue da conceituação inicial por seu caráter não psicologizante, ou seja, por buscar definir uma memória que supõe o enunciado inscrito na história. O estudo da ação do orador encontrou sua contrapartida tardia nos estudos pragmáticos que caracterizariam a linguagem como ação. Mesmo a nova retórica de Perelman não se deteve nesses pontos, embora o autor tenha desenvolvido a noção de temporalidade para explicar a diferença entre a argumentação e a demonstração (distinção proposta por ele). A noção de temporalidade poderia ser de certa forma aproximada às noções de memória e ação do orador, já que o ato de enunciar transcorre simultaneamente num determinado tempo sócio-histórico $e$ num tempo cronológico, pressupondo assim o acionamento de vários níveis de memória para a realização dos enunciados, que por sua vez pressupõem a efetivação de um ato ilocutório.

A lingüística, até pouco tempo, ocupou-se principalmente de estudar o material lingüístico, constituído necessariamente a partir de memórias, abstraindo-o destas últimas. Ao mesmo 
tempo, não considerava em seus estudos aspectos pragmáticos, como os atos ilocutórios e perlocutórios, e mesmo os implícitos, fenômeno que só pode existir porque aciona a memória discursiva dos interlocutores e constitui-se na prática dos falantes em ato ilocutório. Deixavam-se de lado, assim, o passado e o futuro do material lingüístico, sua origem intangível e seu fim como elemento que se articula no corpo das relações discursivas e sociais, num duplo movimento de repetição do passado e construção do futuro. Os estudos da produção lingüística encerravam-se no presente, e com eles as possibilidades de abarcar seus múltiplos sentidos, construídos no tempo, em especial no tempo do discurso.

A análise dos sentidos produzidos pela articulação memória-ação (a primeira entendida como memória discursiva e a última como ação lingüístico-discursiva e pragmática) pode encontrar um caminho promissor no corpo teórico que elegemos como pressupostos teóricos para esta tese, ou seja, uma análise do discurso a que denominamos análise lingüístico-discursiva aliada a conceitos da pragmática. Não conhecemos um único corpo teórico, reconhecido por uma só designação, que dê conta deste desafio. Daí a necessidade de realizar aqui algumas aproximações teóricas, cujos riscos assumimos.

\section{Memória discursiva e interdiscurso}

A noção de memória discursiva está diretamente associada à noção de interdiscursividade (central em nosso trabalho), ao contrário do que se costumava pensar nos primeiros anos de desenvolvimento da $\mathrm{AD}$, quando a noção de memória discursiva se associava diretamente ao conceito de formação discursiva.

Nos primeiros anos da $\mathrm{AD}$, o conceito formação discursiva era um conceito compacto, fechado em si mesmo. Considerava-se a FD algo homogêneo, o que contraria a noção central de dialogicidade intrínseca à linguagem, ou, nos termos de Maingueneau, a noção de primazia do interdiscurso. Segundo Courtine e Marandin (1981), apud Brandão (1993):

O interdiscurso consiste em um processo de reconfiguração incessante no qual uma formação discursiva é conduzida (...) a incorporar elementos preconstruídos 
produzidos no exterior dela própria; a produzir sua redefinição e seu retorno, a suscitar igualmente a lembrança de seus próprios elementos, a organizar sua repetição, mas também a provocar eventualmente seu apagamento, o esquecimento ou mesmo a denegação.

Assim, no interior de uma FD já está configurada a interdiscursividade, pois uma FD não é homogênea. O que faz supor a homogeneidade é o sistema de coerção a que a FD se submete, sistema tal que Maingueneau chama, como já dissemos, de competência discursiva, que “autoriza” certos dizeres e “desautoriza” outros, criando a ilusão de hegemonia. O que dizer e o que não dizer só podem ser definidos a partir de uma memória, que é discursiva, e que é operada pela competência discursiva. Melhor seria chamarmos a essa memória de memória interdiscursiva.

Desta forma, pode-se dizer que a FD se associa à memória discursiva através da mediação da própria interdiscursividade que lhe é constitutiva, embora muitas vezes mascarada, em especial em discursos fortemente institucionalizados.

Do que foi dito até este ponto neste item, pode-se concluir que o tempo passado no discurso, fonte do dizível no presente, é localizável nesta entidade abstrata reconhecida como memória discursiva, não passiva, não identificável como mero sistema de armazenamento, e difícil de descrever de modo a esgotar sua ação. De fato, ela se descreve na medida em que a enunciação a atualiza, quando simultaneamente seus dados se transformam semanticamente, mediante condições de produção novas.

Memória social, memória discursiva e imagem

A memória discursiva só existe porque existe uma memória social. Davallon (em Achard et al,1999) busca defini-la assim: 
Uma primeira constatação se impõe imediatamente: para que haja memória, é preciso que o acontecimento ou o saber registrado saia da indiferença, que ele deixe o domínio da insignificância. É preciso que ele conserve uma força a fim de poder posteriormente fazer impressão. Porque é essa possibilidade de fazer impressão que o termo "lembrança” evoca na linguagem corrente. Um sociólogo um pouco esquecido hoje, é verdade, mas que uma sociologia do conhecimento não poderia ignorar - a saber, M. Halbwachs - caracterizaria aliás a memória como "o que ainda é vivo na consciência do grupo para o indivíduo e para a comunidade”18.(p.25)

Acrescenta a seguir que:

[...] lembrar um acontecimento ou um saber não é forçosamente mobilizar e fazer jogar uma memória social. Há necessidade de que o acontecimento lembrado reencontre sua vivacidade; e, sobretudo, é preciso que ele seja reconstruído a partir de dados e de noções comuns aos diferentes membros da comunidade social.

Assim é que a memória social, ou coletiva, para constituir-se enquanto tal, possui um caráter vivaz e intersubjetivo, não homogêneo (embora se construa na busca do consenso), que corresponde ao caráter dinâmico e interdiscursivo da memória discursiva.

Ocorre que a memória de um grupo tende a se esvair. Em compensação a história construída por esse grupo resiste ao tempo, pois o acontecimento memorizado transformado em história perdura e se estende além dos limites físicos do grupo social que viveu o acontecimento. Segundo hipótese de Davallon, os objetos ditos culturais, portadores de sentido em determinada comunidade, seriam os responsáveis por operar com o que chama de memória societal, espécie de entrecruzamento entre memória social, ou coletiva, e história. Tais objetos seriam o lugar do controle da memória social, lugar físico em que as instâncias do dizer e do não dizer se articulam. E se consideramos que a palavra é objeto cultural por excelência, por extensão é fácil afirmar que ela é a responsável central pelo controle da memória social, sob a forma de memória discursiva.

Importa agora salientar que o objeto cultural palavra, ou discurso (a fim de mantermos a terminologia), a exemplo de outros objetos culturais construídos em outras linguagens ou misturando várias delas (um quadro, um filme, uma peça publicitária, um programa

\footnotetext{
${ }^{18}$ Halbwachs (1950). La mémoire collective, p.70.
} 
televisivo), possui forte carga imagética, cuja característica central é seu imenso poder de agregar sentido, disseminá-lo rapidamente e conservá-lo. Focando-nos mais fortemente no âmbito da linguagem verbal, e voltando à questão central dos gêneros do discurso, podemos dizer que os gêneros discursivos contam não apenas com o poder imagético da palavra isolada, ou seqüenciada em enunciados, mas também com o poder imagético suscitado pela própria concepção do gênero. Daí que um anúncio televisivo se distingue e é compreendido enquanto tal imediatamente, assim como uma petição trabalhista não se confunde com um editorial de jornal e é igualmente compreendida enquanto tal instantaneamente. Exceto, é claro, quando não há por parte do alocutário qualquer conhecimento prévio a respeito dos gêneros do discurso e sua articulação.

Assim, é superficial a idéia que muitos ainda fazem do texto publicitário, por exemplo, visto como objeto que se completa com a inserção de imagens (fotos, desenhos, grafismos, etc), como se ele mesmo, em cada palavra, não suscitasse imagens carregadas de acontecimentos da memória social. Na petição trabalhista, a leitura dos lexemas “requerente" e "requisitante”, para citar um exemplo diretamente ligado ao tema desta tese, aciona numa primeira instância uma imagem de trabalhador no discurso jurídico trabalhista construída socialmente e que está na memória social e discursiva do grupo. Demais elementos que constroem a cenografia do texto (o termo cenografia torna-se ainda mais útil para a análise da construção textual, pois traz embutida a noção de imagem), como a menção do trabalhador em terceira pessoa, a escolha e disposição dos argumentos (do ponto de vista retórico), o uso de uma linguagem reverencial ao juiz, os demais jargões próprio à linguagem jurídica, tudo isto suscita imagens ligadas ao imaginário da instituição direito trabalhista brasileiro. Estas imagens estão nas palavras e no texto como um todo e são a materialização da memória social e discursiva e porta de entrada para a apreensão dos sentidos.

Vemos assim que as posições de Davallon vão ao encontro do que dissemos mais acima: a memória social - e seus mecanismos de controle - se descrevem na medida em que produzimos objetos culturais em diferentes linguagens, assim como a memória discursiva se descreve na medida em que a enunciação a atualiza. 
Como diz Davallon, na mesma obra, com referência a objetos culturais não lingüísticos, mas que aqui estendemos aos objetos lingüístico-discursivos:

Com efeito, se a imagem define posições de leitor abstrato que o espectador concreto é convidado a vir ocupar a fim de poder dar sentido ao que ele tem sob os olhos, isso vai permitir criar, de uma certa maneira, uma comunidade - um acordo de olhares: tudo se passa então como se a imagem colocasse no horizonte de sua percepção a presença de outros espectadores possíveis tendo o mesmo ponto de vista. Do mesmo modo como - explicava Halbwachs - a reconstrução de um acontecimento passado necessita, para se tornar lembrança, da existência de pontos de vista compartilhados pelos membros da comunidade e de noções que lhes são comuns; assim a imagem, por poder operar o acordo dos olhares, apresentaria a capacidade de conferir ao quadro da história a força da lembrança. Ela seria nesse momento o registro da relação intersubjetiva e social. (p.31)

Quando a cenografia típica de uma petição trabalhista, ou de uma audiência trabalhista, evoca imagens como a de um juiz de toga, de um local circunspeto onde se delibera sobre o justo, de um trabalhador-solicitante deslocado do contexto do discurso, de um advogado que assume a frente na defesa deste solicitante sem perder de vista o complexo jogo de interesses que imediatamente se estabelece a partir da entrevista inicial trabalhadoradvogado, tais imagens são portadoras de um sentido de manutenção do estabelecido. A imagem, com sua extraordinária capacidade de fazer-se imediatamente compreender, é que articularia a perpetuação dos sentidos nas memórias social e discursiva.

Podemos dizer que a imagem, posta na e pela cenografia discursiva, pertence ao domínio da atualidade, conforme conceito de Courtine (1981), embora tal conceito não aborde a questão da imagem. Brandão (1993), descrevendo o conceito de domínio de atualidade de Courtine, afirma que: “o efeito de atualidade produzido por este domínio é resultado do desenvolvimento processual dos efeitos de memória: memória que faz irromper um acontecimento passado em uma conjuntura presente, reatualizando-o”. Ora, esta reatualização faz-se através da instauração de uma cenografia que é fundamentalmente imagética. 
Atualização da memória e desregularização

Pêcheux (in Achard et al., 1999), em diálogo com Davallon, compara a imagem operadora de memória social com a recitação de um mito. Na transparência de sua compreensão, a imagem mostra como deve ser lida, comportando no interior dela mesma, portanto, o efeito de repetição e de reconhecimento necessários à perpetuação do sentido. Mas Pêcheux acrescenta que a própria atualização de um elemento de memória em discurso, embora tenda a repeti-lo, sujeita-o ao peso de ser um acontecimento e, portanto, único e passível ao novo. $\mathrm{O}$ acontecimento discursivo em si perturba a memória, pois todo evento enunciativo comporta os não-ditos, os implícitos, que reorientam a produção e a interpretação do discurso.

Pêcheux considera que:

Haveria assim sempre um jogo de força na memória, sob o choque do acontecimento:

$\checkmark$ um jogo de força que visa manter uma regularização pré-existente com os implícitos que ela veicula, confortá-la como "boa forma”, estabilização parafrástica negociando a integração do acontecimento, até absorvê-lo e eventualmente dissolvê-lo;

$\checkmark$ mas também, ao contrário, o jogo de força de uma "desregulação" que vem perturbar a rede dos "implícitos".

Na mesma direção, segundo Courtine (1981), a memória discursiva funcionaria em dois domínios: um domínio da memória, em que atuariam as forças da regularização; e um domínio da atualidade, em que atuariam as forças da desregulação e conseqüentemente da abertura para o novo, e para o outro. Como se vê, o funcionamento da memória discursiva é eminentemente interdiscursivo. Assim é que, voltando a Pêcheux:

A certeza que aparece, em todo caso, no fim desse debate é que uma memória não poderia ser concebida como uma esfera plana, cujas bordas seriam transcendentais históricos e cujo conteúdo seria um sentido homogêneo acumulado ao modo de um reservatório: é necessariamente um espaço móvel de divisões, de disjunções, de deslocamentos e de retomadas, de conflitos de regularização...Um espaço de desdobramentos, réplicas, polêmicas e contra-discursos. (p.56) 
Os processos que levam à desregulação da memória e à abertura do discurso para o outro e para o novo nos remetem ao conceito de domínio da antecipação de Courtine (1981). Brandão (1993) assim descreve o conceito:

Reúne seqüências discursivas que entretêm no nível intradiscursivo relações interpretáveis como efeitos de antecipação.

Segundo Courtine, a presença de um domínio de antecipação na constituição de um corpus discursivo tem o mérito de nos revelar:

1. o caráter necessariamente aberto da relação que uma seqüência discursiva produzida em determinadas condições mantém com seu exterior no seio de um processo. Se há sempre-já do discurso, pode-se acrescentar que haverá um sempre-ainda;

2. a impossibilidade de se atribuir um fim ao processo discursivo;

3. a possibilidade sempre aberta de, a partir dos resultados obtidos no trabalho de análise da relação de uma seqüência discursiva com seu domínio de memória, se poder construir um domínio de antecipação enquanto alvo de uma Análise do Discurso.

Ancorado na memória discursiva, o discurso projeta-se necessariamente para o futuro. Podemos dizer que se projeta para fora de si ao repercutir em seu meio social também como elemento transformador. O processo trabalhista retrata de forma típica essa dupla projeção do discurso: por um lado, o sempre-ainda mantém abertas as possibilidades para novas formações discursivas e novos discursos imiscuírem-se no discurso original, mantendo abertas suas portas para o novo e para o outro; por outro lado, tal discurso se dirige invariavelmente para uma articulação final que escapa dele mesmo e que resultará em uma transformação do meio: em última análise, ao término do processo, um trabalhador terá ou não atendida sua solicitação, uma empresa terá ou não de arcar com o ônus do descumprimento da lei trabalhista. A deliberação do juiz, sua sentença, é o ato ilocutório por excelência. Aplicada a sentença, entendida aqui como ação lingüístico-discursivopragmática, as práticas discursivas se transformam também, pois a jurisprudência gerada no processo em pauta afetará os processos futuros em seus fundamentos discursivos e em suas formulações. 
Ricoeur (1995) diz que o ato de julgar ocorre em dois tempos: (i) num tempo curto, no qual o ato põe fim a uma incerteza; e (ii) num tempo longo, no qual o ato cria jurisprudência. E, referindo-se a Éric Weil, em sua obra Logique de la philosophie, e às ações em tempo curto e longo operadas pelo ato de julgar, afirma: “d’une certain façon, toutes les operations auxquelles nous avon fait allusion, depuis le délibéré jusqu'à la prise de decision, jusqu’à l'arrêt, manifestent le choix dus discours contre la violence” (p. 189) ${ }^{19}$, entendendo-se aqui por violência a desestabilização social que a linguagem visa equacionar tendo em vista seu papel de construtora social.

Assim é que podemos observar no processo trabalhista: (i) a ação de um tempo discursivo, processual, que atravessa o discurso e cada gênero de que tal discurso é constituído. Este tempo processual se caracteriza pela heterogeneidade discursiva, ou seja, pela interdiscursividade que agrupa de forma complexa em um mesmo tempo (o tempo da enunciação) os domínios da memória, da atualidade e da antecipação. As marcas lingüísticas desse tempo processual só podem ocorrer e ser apreendidas porque todo o processo trabalhista (e no mais, como tudo que é linguagem) se atualiza enquanto materialidade (ii) no tempo linear, seqüencial e horizontal, que organiza as formulações de acordo com, em nosso caso, a cronologia própria ao processo trabalhista (primeiro a entrevista, depois a petição, depois a audiência). O tempo cronológico traz em si o tempo processual do discurso, ou as possibilidades de apreensão deste último.

\footnotetext{
${ }^{19}$ De uma certa maneira, todas as operações a que fizemos alusão, desde o deliberado até a tomada de decisão, até a sentença, manifestam a escolha do discurso contra a violência.
} 
TRABALHO E(M) DISCURSO 


\section{TRABALHO E(M) DISCURSO}

3.1 As transformações no mundo do trabalho: o discurso do trabalho como bem desejável

A idéia contemporânea (e ocidental) de trabalho só nasce efetivamente com o capitalismo manufatureiro, no final do século XVIII. Até então entendia-se por trabalho a labuta diária que tivesse por fim a produção de bens de consumo ou serviços necessários à sobrevivência e que exigissem ser renovados e repostos com regularidade. Tal atividade era própria aos servos, aos trabalhadores braçais e às mulheres, pessoas consideradas “inferiores” na escala social ou, em outras palavras, mais próximas ao mundo natural. O trabalho não era motivo de reconhecimento pessoal, como é hoje. Ao contrário, a meta do homem ocidental prémoderno era livrar-se do trabalho, considerado necessário para satisfação das necessidades humanas básicas, mas em si mesmo fator de aprisionamento. A liberdade não estava na esfera da produção econômica (levada a cabo pelo trabalho), mas na esfera da política, da vida pública na pólis, local em que o indivíduo atuava para além do reino da necessidade e podia desenvolver-se intelectual, espiritual e artisticamente, movido pelo que se considerava sua determinação soberana (sua liberdade).

A idéia que predominou de Platão até muito recentemente é a de que a liberdade (entendida como aquilo que qualifica o humano, acima da natureza e de suas contingências) só começa quando as necessidades materiais estão satisfeitas. Só neste ponto é possível ao homem tornar-se sujeito capaz de conduta moral. A submissão ao trabalho de subsistência retiraria do homem aquilo que o qualifica como homem e, assim sendo, sua capacidade de pensar e agir moralmente. Claro está que, de acordo com as formas de pensar desses séculos todos, isto não valeria para as “classes inferiores de seres humanos", para quem expressões como “liberdade” e “conduta moral” não fariam sentido. Tais pessoas, consideradas muito próximas ao mundo natural, seriam incapazes de ascender à esfera da liberdade. Importa frisar, no entanto, que "o trabalho era indigno do cidadão não porque fosse reservado às mulheres e aos escravos, mas, ao contrário, era reservado às mulheres e aos escravos porque trabalhar era 'sujeitar-se à necessidade'” (Gorz: 2003). Está pressuposto, por conseguinte, que mulheres e escravos seriam mais afeitos à sujeição, e portanto indicados para realizar todas as tarefas contingenciais. 
A produção de bens e serviços acontecia, assim, na esfera familiar. Dentro da casa, cabia à mulher organizar e realizar o trabalho doméstico. Fora, cabia aos trabalhadores braçais e servos a produção dos demais bens e serviços (necessários à subsistência daquela família e às trocas, que se realizavam entre famílias). A necessidade econômica e o trabalho confundiam-se, assim, com a esfera privada, em que a hierarquia dos diversos tipos de trabalho predominava. A família era então o lugar da desigualdade. E o trabalho não significava, como significa hoje, possibilidade de inclusão social, muito ao contrário: era, antes, um princípio de exclusão. A esfera pública era por sua vez a esfera da igualdade. Libertos das contingências materiais, os homens públicos da pólis exerciam sua liberdade ao determinar, na praça pública, os modos de pensar e os destinos da comunidade.

Os artesãos eram uma categoria à parte de trabalhadores, na medida em que não produziam bens ou serviços de subsistência, e sim bens duráveis. Tais bens eram remunerados individualmente, por obra, o que emprestava uma qualidade diferente à palavra trabalho. Com os anos, os tecelões também passaram a ocupar uma categoria distinta, pela forma como começaram a organizar o próprio trabalho, em pequenas fábricas domiciliares. Os empregados dessas pequenas fábricas, remunerados, não eram mais trabalhadores regulados pela instância opressiva da necessidade, mas já se esboçava um sentido de profissão que qualificava positivamente o trabalho realizado. Artesãos e tecelões articularam seus afazeres a um estilo de viver, que os retirava da esfera pura e simples da subsistência. Lentas e graduais, as transformações sociais, motivadas grandemente pela inovação tecnológica, reverteram paulatinamente o sentido da palavra trabalho.

De qualquer forma, não obstante as transformações que atenuaram o abismo entre as relações trabalho $\mathrm{x}$ necessidade e não-trabalho $\mathrm{x}$ liberdade ${ }^{20}$, predominou por séculos um certo tipo de racionalidade que garantia a estabilidade social, na medida em que os papéis sociais eram estáveis no tempo. O ritmo em que as mudanças ocorriam (lento, se

\footnotetext{
${ }^{20}$ Tal atenuação da oposição trabalho/necessidade x não-trabalho/liberdade estaria na raiz da ascensão do fator econômico na vida do homem ocidental. A relação que se estabelecia entre um modo de produção e um estilo de viver aproximava o âmbito econômico das demais esferas da vida (política, intelectual, cultural espiritual), permitindo que aos poucos o âmbito econômico se sobrepusesse aos demais e/ou os impregnasse. Se trabalhar passa a significar produzir um estilo de vida e uma certa maneira de ser livre, o trabalho passa a significar também um passe para a liberdade, cada vez mais compreendida como liberdade no sentido estritamente material do termo.
} 
comparado ao ritmo das transformações a partir do final do século XIX) colaborava para que os novos sistemas de ação, pensamento e valor se assentassem sem rupturas profundas das tradições. A racionalidade em vigor por séculos permitia, por exemplo, na França do século XVII, que os trabalhadores braçais, por jornada, diaristas e aprendizes recebessem remuneração que era controlada por corporações conforme o ramo de atividade, corporações tais que garantiam remuneração e quantidade de horas de trabalho equivalentes, a fim de, em última análise, preservar o estilo de vida dos membros da categoria. Novas técnicas ou novas máquinas deviam ser aprovadas por conselhos formados por comerciantes e tecelões, e depois autorizadas por juízes, a fim de garantir que nenhuma novidade pudesse prejudicar os demais. Havia um sistema de auto-regulação que funcionava fora dos parâmetros do que no capitalismo industrial (que sucedeu o capitalismo manufatureiro) passou a ser conhecido como racionalidade econômica, que teria em seu cerne a máxima da maior produção ao menor custo, à revelia do estilo de vida; ou, em sua versão mais recente, a máxima do “compre seu estilo de vida, produzindo mais”. Durante séculos, e mesmo nos primórdios do capitalismo, não se concebia impingir a um tecelão uma meta de produção. Os tecelões, assim como os artesãos e camponeses, não faziam o que faziam apenas como ganha-pão, mas porque aquele era seu modo de vida, regido por tradições, respeitadas pelos primeiros capitalistas.

Com o advento da linha de produção, começa-se a esboçar mais um novo sentido para a palavra trabalho, cada vez mais moldado pela racionalidade econômica que se desenvolvia. Cabe ressaltar que tal racionalidade só teve condições de se impor porque emancipou-se de todos os outros princípios de racionalidade, tendo se desenvolvido principalmente a partir do conceito de utilitarismo, de John Stuart Mill. Este conceito, apresentado originalmente em 1861, foi fundamental para o estabelecimento da conhecida equação econômica denominada relação custo-benefício, que rege a produção e as relações de trabalho até hoje. Como diz Max Weber ${ }^{21}$ :

A racionalização à base de um cálculo rigoroso é uma das características fundamentais da empresa capitalista individual, precavida e circunspectamente orientada para o resultado esperado. Que contraste com o cotidiano do camponês,

\footnotetext{
${ }^{21}$ Max Weber, L’ Éthique protestante et l'esprit du capitalisme. Paris, Plon/Agora, 1985 (apud Gorz, 2003).
} 
com a rotina e os privilégios do artesão das antigas corporações ou com o capitalista aventureiro! Contudo, considerada do ponto de vista da felicidade pessoal, essa racionalização expressa quão irracional é a conduta que faz o homem existir em função de seus negócios, e não o inverso.

O novo sentido que se esboçava não apenas qualificava definitivamente o trabalho de forma positiva, deixando de referir-se apenas à esfera do contingente, como também o colocava adiante das tradições e demais interesses humanos, que passaram a ser secundários, quando não a existir unicamente para embasar a atividade econômica. Gorz (2003) afirma que, referindo-se às novas formas de organização do trabalho que surgem a partir da racionalidade econômica:

A organização científica do trabalho industrial constituiu o esforço constante para distinguir o trabalho, categoria econômica quantificável, da pessoa viva do trabalhador. O esforço, de início, assumiu a forma de uma mecanização, não do trabalho, mas do próprio trabalhador: isto é, uma forma de coerção ao rendimento, pela imposição de ritmos ou cadências. O salário por rendimento, afinal a forma economicamente mais racional, revelou-se originalmente impraticável. Pois, para os operários dos fins do século XVIII, o “trabalho” era uma habilidade intuitiva, integrada a um ritmo de vida ancestral, e ninguém teria tido a idéia de intensificar e prolongar seu esforço com o intuito de ganhar mais. O operário "não perguntava: quanto posso ganhar por dia se forneço o máximo de trabalho possível? Sua questão era: quanto devo trabalhar para ganhar os 2,50 marcos que recebo hoje e que garantem minhas necessidades corriqueiras?"22

Assim, paulatinamente, o trabalho - que nesse momento histórico já se liberara da pecha de constituir-se como meio vil de sobrevivência e adquirira sentido positivo por caracterizar o domínio de uma técnica (ofício) que qualificava um indivíduo e o grupo e lhes proporcionava um estilo de viver - passa a desarticular-se do mundo da vida, ao qual até então unia-se organicamente, para tornar-se simples meio de ganhar a vida. Em outras palavras, o tempo de trabalho e o tempo de viver foram desconectados. Gorz, mais uma vez, descreve muito bem este estado de coisas:

[...] o trabalho, suas ferramentas, seus produtos, adquiriram uma realidade separada do trabalhador e diziam agora respeito a decisões estranhas a ele. A satisfação de "fazer uma obra" comum e o prazer de "fazer" foram suprimidos em nome das

\footnotetext{
${ }^{22}$ Gorz cita Max Weber, op. cit.
} 
satisfações que só o dinheiro pode comprar. Dito de outra maneira, o trabalho concreto só pôde ser transformado naquilo que Marx chamará de "trabalho abstrato" ao engendrar, no lugar do operário-produtor, o trabalhador-consumidor: isto é, o indivíduo social que não produz nada do que consome e não consome nada do que produz; o indivíduo para o qual a finalidade essencial do trabalho é ganhar o suficiente para comprar as mercadorias produzidas e definidas pela máquina social em seu conjunto.

Restava ao trabalhador alienado do mundo da vida unir-se aos demais trabalhadores das linhas de produção, alimentando cada qual, no grupo e em grupo, o sentido perdido de produção de uma obra. Agora, no entanto, tal produção via-se materializada não num objeto, que afinal permanecia alheio à esfera pessoal de cada trabalhador envolvido em sua produção, mas sim no próprio realizar em grupo, grupo este que procurava nutrir-se de seus membros em busca de uma autonomia produtiva coletiva equivalente à autonomia produtiva individual dos antigos artesãos. A utopia de uma coletividade produtiva autônoma e dominante, construída em grande parte pelo marxismo, acabou por aprofundar a desconexão entre mundo da vida e mundo do trabalho, na medida em que gerou um esfacelamento ainda maior no indivíduo, que não encontrou no grupo de trabalho substituto para o plano existencial.

Neste percurso de desconexão trabalho-vida, foram consolidados discursos de promoção da convivência de éticas díspares, que permitiram ao indivíduo, através de mecanismos de justificação, agir de modo contraditório sem perceber as contradições. Permitiram ao engenheiro químico, por exemplo, trabalhar na indústria bélica durante a semana e nos finais de semana participar de campanhas em prol do meio ambiente; ou ao trabalhador de quem se exige pouco esforço intelectual dedicar horas de seu dia a um afazer e manter sua mente, durante todas essas horas, fixada no jogo de futebol da noite passada. Tal esfacelamento não impede a existência de compromisso e responsabilidade com o trabalho, mas tais características aparecem muitas vezes descoladas das crenças pessoais, uma vez que o trabalho é sempre meio e não fim.

O trabalho-meio de hoje se assemelha ao trabalho-meio dos idos da pólis grega, com duas diferenças basais: a de que hoje é desejável e necessário que todos os membros capazes em uma comunidade trabalhem (o trabalho-meio não se destina mais apenas aos servos e 
afins); e a de que todos sejam remunerados, de preferência bem remunerados. A ideologia do trabalho como um bem consolidou-se como uma das mais fortes ideologias naturalizadas de nosso tempo. O discurso do trabalho como bem desejável e meio para um fim mascara a dicotomia (construída pelo primado da economia e do capitalismo) entre mundo do trabalho e mundo da vida. Observa-se no mundo do trabalho, por um lado, o discurso empresarial - grande construtor/perpetuador do discurso do trabalho como bem desejável - que atua embasando ações que tragam cada vez mais benefícios aos empregados mais qualificados, construindo um sentido de compensação nos trabalhadores, que pensam: “desconecto minha vida do meu trabalho e compenso esta ruptura com um bom salário, ajuda de custo para moradia, carro da empresa, seguro saúde, seguro de vida, $14^{\circ}$. salário...”; e, por outro lado, os discursos do trabalhador e dos sindicatos, que se articulam exatamente nas mesmas bases: se não há bons salários e benefícios, é preciso lutar para consegui-los e com isto compensar a ruptura trabalho $\mathrm{x}$ vida. Criou-se, em suma, o sentido geral de que tal compensação é possível.

A publicidade é o grande instrumento de que o discurso econômico em prol do trabalho como bem desejável se apropria para garantir seus objetivos. Afinal, o trabalhador, para aceitar sinceramente a ruptura que lhe é impingida, precisa ser educado a tornar-se trabalhador-consumidor, cabendo à publicidade o papel de educador. É preciso, como diz Gorz (2003), persuadir os indivíduos de que os consumos propostos compensam largamente os sacrifícios com os quais devem aquiescer para obtê-los e de que tais consumos constituem nicho de felicidade e liberdade. E quanto mais tais consumos se relacionem ao supérfluo, melhor, pois é justamente o supérfluo que garante ao indivíduo a evasão do coletivo e a obtenção da agradável sensação de soberania privada, sentimento associado ao de liberdade. As políticas de recursos humanos, que pretendem incentivar o trabalhador a esposar os objetivos da empresa e portanto vir a amar seu trabalho são outro instrumento importante que, de fora para dentro (como na publicidade), procura criar um vínculo forte entre trabalhador e empresa, que nubla a percepção de que, no mais das vezes, os objetivos da empresa não só são muito diferentes dos objetivos do trabalhador, como também a eles se opõem. 
Em um país como o Brasil, no qual aos problemas sociais soma-se o problema do desemprego, o trabalho como bem desejável torna-se um bem desejável inatingível. Se este é o bem que abre as portas para demais bens que, em tese, libertam o trabalhador e promovem sua ascensão (liberdade e ascensão entendidas restritamente do ponto de vista econômico), sua supressão o condena de vez ao aprisionamento e à perda do sentido da vida. Não é sem razão que tantos trabalhadores desempregados recorrem à ajuda de seitas e religiões que lhes prometem os meios para conseguir o emprego e que, para os que preferem o ponto de vista psicológico, os livros de auto-ajuda sobre empregabilidade têm assegurado um grande público. Ter um emprego no Brasil hoje não significa apenas garantir o sustento material da família, mas assegurar os meios de garantir um lugar social, um meio de individualizar-se, um meio de ser cidadão livre em uma pólis que continua a não disponibilizar praças públicas aos não-livres. Talvez tenhamos constituído sociedades compostas apenas de escravos, homens para quem o trabalho é meio e para quem suas vidas pessoais nada têm a ver com ele. Ainda assim, influenciados pela ideologia do trabalho como bem desejável, almejam-no na ilusão de que possa ser meio para sua liberdade. A grande contradição está no fato de que tal liberdade se limita ao nível material/econômico e, portanto, será sempre uma meia-liberdade. O desemprego ${ }^{23}$, ao estampar na face do trabalhador não só as contradições e injustiças do mundo do trabalho como também o vazio existencial de sua vida, tem a virtude de desmascarar a dicotomia construída entre mundo da vida e mundo do trabalho e de mostrar que o fator econômico não pode substituir ou incluir em si mesmo todas as esferas da vida humana ${ }^{24}$.

O desemprego, assim como o trabalho precarizado do qual falaremos adiante, apontam o dedo para um fato irrefutável: trabalhar (e aqui o sentido de trabalhar incorpora seus desenvolvimentos em séculos) não é apenas produzir riquezas econômicas, é sempre também uma maneira de produzir-se a si mesmo (Gorz: 2003). As questões que irão

\footnotetext{
${ }^{23}$ Na visão marxista convencional, o desemprego é o exército de reserva do trabalho, mão de obra excedente disposta a oferecer-se a baixos salários. Conforme nos diz Braverman (1987): "Nas condições do capitalismo, o desemprego não é uma aberração, mas uma parte necessária do mecanismo de trabalho do modo capitalista de produção".

${ }^{24}$ A racionalidade econômica se apóia na crescente matematização de seus métodos e formalizações para justificar sua pretensão de formuladora de verdades inquestionáveis, que dispensam as próprias intenções de seus promotores. Os procedimentos e cálculos econômicos se fecham a qualquer reflexão sobre o problema que os originou, permitindo a crítica apenas no que diz respeito ao método. A ilusão de que a racionalidade econômica está acima de qualquer racionalidade é perpetuada pelo discurso do trabalho como bem desejável.
} 
influenciar o desenvolvimento desta tese são, em suma: como o trabalho pode ser vivido de modo a imprimir sentido à vida do indivíduo, sem mutilá-lo? E mais especificamente: como a justiça do trabalho, entendida como direito de solidariedade, como veremos a seguir, configura-se (ou não), no Brasil, como um dos caminhos possíveis em prol da re-conexão entre trabalho e vida, entre produção econômica e produção de si? E mais especificamente ainda: em que medida a acurada observação dos discursos, gêneros e textos do discurso jurídico trabalhista se articulam hoje (ou não) na mesma direção? Há possibilidade de interferir favoravelmente em prol da reintegração trabalho-vida a partir da produção textual, em particular da produção do discurso jurídico trabalhista?

\subsection{A racionalidade econômica do novo capitalismo e o mundo do trabalho no Brasil}

A racionalidade econômica não atua apenas alimentando o discurso do trabalho como bem desejável. Atua igualmente influenciando um certo tipo de compreensão do que seja trabalho, incorporando à noção atual o conceito de flexibilidade. Assim, para obter um emprego não basta especializar-se, é preciso aprender a ser flexível, que significa: correr riscos constantemente, aceitar novos desafios, adaptar-se rapidamente a situações inusitadas, estar pronto a assumir cargos e funções imediatamente, viajar e/ou mudar de endereço a serviço da empresa quantas vezes for preciso, negociar e renegociar constantemente os próprios ganhos e as condições gerais de trabalho, etc. O trabalho como bem desejável está sendo moldado de acordo com a mais recente forma de capitalismo, já instalada nas grandes cidades brasileiras, chamada capitalismo flexível.

Sennett (1999) alerta para a ilusão difundida pelo neoliberalismo de que o trabalhador moderno, eleito pelo novo capitalismo (independente, empreendedor, afeito a correr riscos e a se flexibilizar diante das mudanças constantes do panorama político-econômico), signifique um avanço e uma maneira de equacionar as disparidades capital $\mathrm{x}$ trabalho. Mostra que os trabalhadores que atuam em empresas modernas não são mais felizes ou mais realizados, nem possuem voz mais ativa que seus colegas do passado. Sofrem igualmente "injustiças" decorrentes da disparidade entre os poderes, sofrimento este aguçado pela crença de que tal disparidade estaria ultrapassada. Esta nova maneira com que se configura o mundo do trabalho (e que já está instalada nos principais centros urbanos 
brasileiros) não favorece o trabalhador, como poderia se supor, mas leva a uma corrosão de caráter, a uma dilaceração do "eu”, nos níveis pessoal e social. O termo caráter, para Sennett, “concentra-se sobretudo no aspecto a longo prazo de nossa experiência emocional. É expresso pela lealdade e o compromisso mútuo, pela busca de metas a longo prazo, ou pela prática de adiar a satisfação em troca de um fim futuro”.

A conseqüência social mais grave desta flexibilidade que leva à corrosão do caráter é o fim dos laços de compromisso mútuo, já que as instituições vivem se desfazendo, se incorporando a outras ou sendo continuamente reprojetadas. Metas a longo prazo, que são parte dos anseios humanos, que envolvem por sua vez estabelecimento de laços duradouros, não podem mais existir em uma economia dedicada ao curto prazo. Um constante estado de instabilidade passa a ser aceito como "natural" no mundo do trabalho que se esboça. Eis a raiz da segunda ideologia dominante, paralela à ideologia do trabalho como bem desejável: a ideologia da instabilidade no trabalho como algo inevitável e aceitável.

Nesse contexto, as reclamações trabalhistas, ao estilo de um já "velho" capitalismo, não seriam mais a forma de expressão formal e legal através da qual o trabalhador buscaria direitos supostamente suprimidos. O caminho do capitalismo flexível leva à prática das conciliações diretas entre empregado e empregador, sob pretexto de que o acionamento da justiça do trabalho implicaria aguardar muito tempo para a resolução do conflito e, mesmo que os valores acordados na conciliação sejam menores que os eventualmente determinados pelo juiz, vale a regra do aqui e agora própria ao perfil do capitalismo flexível. Como diz Sennett (1999), pede-se aos trabalhadores que “dependam cada vez menos de leis e procedimentos formais”, o que não raro leva à estabilização de procedimentos paralelos de conciliação, muitos até mesmo ilegais. Faria (1984), referindo-se ao capitalismo industrial nos Estados Unidos, que já trazia em seu bojo as perversidades da organização flexível e que gerou mecanismos ilegais de acordos entre empregadores e empregados, afirma:

Nesse sentido, pois, ao ser estratificada e massificada, aberta e instável, estigmatizada pela crescente diferenciação de suas partes e caracterizada pela necessidade cada vez maior de coordenação de suas funções, a sociedade industrial permite encontrar mecanismos informais e/ou para-oficiais destinados a garantir um mínimo de segurança e estabilidade nas relações sociais travadas no âmbito de 
determinados grupos ou classes. As grandes corporações americanas, por exemplo, em caso de confronto de interesses, muitas vezes abandonam as cláusulas contratuais previamente acordadas na conformidade da lei e buscam soluções conciliatórias em negociações diretas - isso quando não aceitam a mediação de um âmbito por elas nomeado. Do mesmo modo, por mais que existam segmentos sociais que não conhecem a legislação, não tendo acesso a serviços advocatícios e aos órgãos judiciários, nem por isso deixam de se envolver nos seus próprios conflitos - e estes, muitas vezes, também acabam sendo equacionados por padrões e procedimentos que, apenas acidentalmente, têm alguma semelhança com os do direito positivo estatal.

A consideração mais importante a que chega, logo adiante, é a de que "tais mecanismos são originados de fatores sócio-econômicos, de períodos de ruptura social ou mesmo da conformação específica de conflito de classe numa área específica da reprodução social”. A lei trabalhista pode estar deixando (e de fato está) de acompanhar a intensificação do grau de complexidade dos conflitos e tensões nas sociedades capitalistas atuais, mas isto se dá mais porque as transformações sócio-econômicas se tornam mais complexas a velocidade extraordinária e menos porque a justiça é lenta, como se costuma dizer. Há descompasso, sem dúvida, mas cabe antes de tudo olhar com mais atenção para as origens econômicas e sociais que o geram e que estão imiscuídas no paradigma do capitalismo flexível, cuja discussão no mundo do trabalho é apagada pelos discursos naturalizantes em prol de um certo tipo de trabalhador e de um certo tipo de produção do trabalho.

No Brasil, as Comissões de Conciliação Prévia (CCPs), órgãos privados criados em 2000 pela Lei 9.958 com o objetivo de resolver os conflitos antes de uma eventual ação na justiça do trabalho, tornaram-se em 2003 alvo de investigação do Ministério Público Federal e da Delegacia Regional do Trabalho de São Paulo, porque estariam se transformando em um negócio rentável para sindicatos e empresas. Algumas comissões cobram taxas para realizar as conciliações e negociam direitos básicos dos trabalhadores, que não deveriam ser sequer discutidos pois constituem direito garantido. O parcelamento da verba rescisória é outra ilegalidade sistematicamente proposta pelas comissões. Em entrevista concedida ao jornal Folha de S.Paulo de 29/09/2003, o então presidente do Tribunal Superior do Trabalho, Francisco Fausto, alegou que as CCPs só perderiam em fonte de arrecadação ilícita para o tráfico de entorpecentes. Em uma economia capitalista flexível, cujos discursos de legitimação instituem a flexibilização e a negociação como qualidades necessárias, em uma 
tal economia em que decisões no curto prazo prevalecem, o trabalhador preferirá arcar com o custo da conciliação prévia, acreditando estar se beneficiando, a acionar a justiça do trabalho.

Os discursos de legitimação do capitalismo flexível imiscuem-se dentro do próprio discurso jurídico trabalhista na tentativa de subverter direitos trabalhistas já sedimentados. O Projeto de Lei 5.483/01, do Poder Executivo, é mostra lingüística deste processo, conforme se vê na redação proposta para o artigo 618 da Consolidação das Leis do Trabalho (CLT): “as condições de trabalho ajustadas mediante convenção ou acordo coletivo prevalecem sobre o disposto em lei, desde que não contrariem a Constituição Federal e as normas de segurança e saúde do trabalho”. A ambivalência criada neste trecho é a marca lingüístico-discursiva desta interdiscursividade, que pode levar a práticas sociais prejudiciais ao trabalhador. Tal interdiscursividade se explica em termos de nossa análise do discurso porque tanto os discursos econômicos quanto os discursos jurídicos são discursos de poder e, portanto, trazem em si a abertura um para o outro.

Os acordos que modificam as relações empregado x empregador no Brasil, sob a influência do discurso da economia flexível, têm produzido fenômenos estranhos. Entre eles, o crescimento do número de "patrões” no país. Em 2003, quase meio milhão de brasileiros abriram empresa (conforme dados levantados pelo jornalista Gilberto Dimenstein, em artigo publicado na Folha de S.Paulo de 28/09/2003). Na verdade, tais patrões são na prática apenas empregados de si mesmos, conforme expressão de Dimenstein, embora sejam tratados legalmente como patrões. Ocorre que entre estar desempregado e aceitar uma posição sem carteira assinada, firmando contrato $^{25}$ de prestação de serviços com o empregador (e patrão de fato), o trabalhador prefere a segunda opção. Como eterno freelancer, o trabalhador flexível brasileiro é também o eterno trabalhador provisório ${ }^{26}$.

\footnotetext{
${ }^{25}$ Como se verá adiante, o gênero contrato pressupõe que as partes envolvidas estejam em pé de igualdade para que um contrato constitua-se como contrato de fato. Nas relações trabalhistas, o contrato é uma ficção, pois não há paridade entre as partes.

${ }^{26}$ Sachs (2004) traça um esboço do quadro pouco animador do mundo do trabalho no Brasil para o trabalhador: "O Brasil entrou no século XXI com um aparelho industrial moderno e diversificado e um setor de agronegócios que lhe confere a liderança mundial em vários setores. No entanto, a sua estrutura ocupacional reflete o atraso social do país. Segundo a PNAD de 2002, os empregados sem carteira assinada constituíam 24,2\% da $\mathrm{PEA}(*)$ e os empregados por conta própria 22,3\%. 4,2\% das pessoas ocupadas
} 
Outro fenômeno comum é a presença cada vez mais intensiva do trabalho precarizado. Os que não têm condições de ajustar-se aos empregadores através dos "contratos" de prestação de serviços, aceitam trabalhar sem vínculo de nenhum tipo, sem garantia alguma, sem benefícios e, muitas vezes, sem as condições básicas de segurança e saúde exigidas por lei, simplesmente para poder sobreviver. Para tais pessoas, não há alternativa: a escolha é entre o trabalho precarizado e a miséria. A lei trabalhista inexiste para um grupo crescente de trabalhadores, indivíduos que não pertencem a uma categoria ou classe, a quem o especialista em direito do trabalho brasileiro, José Pastore, chama de “desclassificados”.

Ironicamente, a economia do novo capitalismo flexível - e antes dele do capitalismo industrial - em tese capaz de produzir hoje alimentos para 9 bilhões de humanos, mas que na prática condena 1 bilhão à fome e à má nutrição, é a responsável pela miséria material no planeta, em índices jamais vistos. Rahnema (2003), diplomata iraniano e atualmente cidadão francês e professor na universidade de Claremont (Califórnia), especializado nos problemas relacionados à pobreza no mundo, considera a miséria um produto por excelência do Homo oeconomicus . Segundo o autor, esta perversidade se mostraria de forma especialmente grave nos países pobres que, sob pretexto de desenvolvimento, destroem com freqüência os equilíbrios culturais produzidos por suas populações durante séculos (e aqui refere-se particularmente ao Irã, mas podemos relacionar sua fala com certa facilidade à realidade brasileira e a de outros países do terceiro mundo), para criar novas necessidades, sem as condições necessárias para permitir que elas sejam satisfeitas de forma durável. A ideologia do consumo, uma das bases do capitalismo flexível, teria destruído sociedades pobres, mas de certa forma organizadas, e criado a miséria. O sistema político-econômico preponderante impõe a milhares de pessoas um modelo econômico e de

trabalhavam unicamente para o próprio consumo, e 11,7\% não tinham rendimento monetário algum. 27,1\% dos trabalhadores tinham rendimentos inferiores ou iguais a um salário mínimo, 26,3\% de um a dois salários mínimos, $12,4 \%$ de dois a três salários mínimos, enquanto apenas 1,3\% superava os vinte salários mínimos. A economia brasileira é constituída por uma quantidade de empresas modernas e eficientes, algumas de status mundial, imersa num sem número de atividades de baixíssima produtividade. A riqueza está concentrada nela ao passo que uma parcela importante da população busca a sobrevivência na informalidade. O aumento do trabalho precário foi a principal característica do mercado em 2003. [...] Entre dezembro de 2002 e dezembro de 2003, subiu em 812 mil o número de trabalhadores ocupados nas seis principais regiões metropolitanas. Em contrapartida, a quantidade de empregados com carteira de trabalho no setor privado encolheu em 907 mil, e enquanto cresceu em 446 mil o número de empregados sem carteira e em 334 mil o de trabalhadores por conta própria”. (*) PEA = população economicamente ativa. 
governança que não tem relação com suas aspirações e as alija de seus próprios meios de lutar contra a miséria. Leva-as, enfim, a abrir mão de suas tradições e seus valores para incorporarem-se a um mundo do trabalho que as apartará cada vez mais, e cegamente, do mundo da vida.

A contrapartida a esta situação - a única que poderá garantir um futuro melhor para a humanidade, promovendo a reintegração trabalho-vida - é, segundo Rahnema (e com a qual concordamos), a revolução interior combinada a uma ação social radicalmente diferente. A revolução interior diz respeito ao esforço que o homem ocidental deverá empreender para parar de refletir em termos de acumulação e conforto. A ação social radical diz respeito à criação de novos paradigmas para a economia, em direção provavelmente ao que hoje tem se chamado, em nível embrionário, de economia solidária. A ação radical deverá ser empreendida de modo a realocar a economia para dentro da esfera do humano, desconstruindo os discursos que promovem o seu inverso e criam o sentido de submissão do humano à esfera econômica.

\subsection{O papel dos sindicatos}

Os sindicatos já existiam antes do capitalismo industrial, sob a forma dos sindicatos de ofícios. Os sindicatos de ofícios abrangiam número pequeno de associados e defendiam os interesses de trabalhadores de setores produtivos ligados à incipiente indústria manufatureira. Os sindicatos de ofício já possuíam as características do que se designa hoje por sindicato:

[...] organizações permanentes de trabalhadores assalariados formalmente destinadas a tentar obter vantagens para seus associados ou para o conjunto dos trabalhadores mediante negociações com as empresas e com o Estado, pressões políticas e outros meios de atuação. (Rodrigues, 1999)

Evidentemente que na prática o sindicalismo pode assumir várias feições, conforme sejam as condições sócio-históricas que determinaram seu surgimento em determinado local. Mas, como bem diz Rodrigues (1999), é necessário precisar o termo, para que se discuta sobre um certo tipo de organização institucional, e não sobre tantas outras que muitas vezes se 
confundem com sindicatos, por assumirem forma de atuação similar. É o caso das cooperativas, sociedades de auxílio mútuo, ONGs, etc. O que distingue o sindicato, em meio a outras instituições afins, é sua função reivindicatória, que tem por pressuposta a idéia de que há sempre algum tipo de divergência entre os interesses, por um lado, do empregador e, por outro, dos empregados. Isto não equivale a afirmar que existe incompatibilidade total e irreversível entre capital e trabalho, entre lucro e salário, mas sim a afirmar que certa incompatibilidade é intrínseca à relação empregador x empregado e é ela que justifica a existência do sindicato.

A questão que se coloca para efeito desta tese é precisar as relações sindicato (entendido de acordo com a descrição acima) e mundo do trabalho, em especial no Brasil, a fim de verificarmos se um aspecto importante de nossa hipótese inicial está correto: o de que o trabalhador encontraria hoje maior espaço de representação de sua voz no discurso jurídico trabalhista do que no discurso sindical. Se sim, reforça-se a necessidade de compreendermos melhor os modos de representação da voz do trabalhador no discurso jurídico trabalhista para, em seguida, podermos propor, sobre bases lingüístico-discursivas, algumas considerações sobre o mundo do trabalho no Brasil, a título de contribuição para a discussão atualíssima sobre as transformações do mundo do trabalho em todo o globo. Nossa preocupação, portanto, não é dissertar sobre a história do sindicalismo, nem discutir seu futuro, muito menos nos posicionarmos em relação a sua (de)crescente importância hoje, o que fugiria aos objetivos desta pesquisa. Nosso objetivo é completar o quadro geral do que é o mundo do trabalho nas sociedades ocidentais atuais, quadro este que inclui obrigatoriamente o sindicalismo, instituição que emerge com toda a força a partir do capitalismo industrial e terá papel determinante para a estabilização das relações de trabalho e a preservação e valorização dos novos trabalhadores de então.

As forças sindicais atuaram com força no Brasil durante boa parte do século XX, não sem lutas violentas e um marcante caráter ideológico. O sindicalismo brasileiro nasce ligado ao partido comunista, o que não poderia ser diferente, por estar o partido, desde o seu início e em qualquer lugar do mundo, pautado pela luta em defesa dos trabalhadores. O partido comunista no Brasil atuou na esteira dos partidos comunistas russo e europeus, em uma 
sincronia que custaria a vida de muitos correligionários e ao mesmo tempo ajudaria a garantir condições de trabalho a muitos brasileiros. Sua imbricação com o governo e forças conservadoras na era getulista, no entanto, leva o sindicalismo brasileiro a assumir um perfil bastante próprio, marcado por certo tipo de corporativismo que o afastará pouco a pouco da grande massa de trabalhadores e centralizará sua ação em grupos de trabalhadores atuantes em setores da economia que interessava aos governos fazer prosperar ou em setores sociais para os quais convinha manter uma representatividade atuante dos trabalhadores (como na educação).

Hoje observa-se que a grande massa de trabalhadores brasileiros não é sindicalizada, ou pertence a sindicatos de pouca expressão e poder de fogo. Ao mesmo tempo, observa-se uma quantidade crescente de trabalhadores autônomos (de forma precária ou não) sem respaldo sindical. Acrescente-se que não há sindicato para lutar pelos direitos dos “desclassificados”, para citar expressão de José Pastore. A própria organização da economia não permite a estabilização de sindicatos para muitos setores, uma vez que, como já foi dito, as instituições (públicas e privadas) nascem, fundem-se e desaparecem com enorme rapidez e a exigência por trabalhadores flexíveis torna difícil a estabilização de classes passíveis de representação sindical. Da mesma forma, as antigas classes de trabalhadores encontram-se em extinção ou vivendo profundas transformações das quais os velhos sindicatos que as representam não têm conseguido dar conta.

O capitalismo flexível tem feito surgir o que se tem chamado de sociedade de serviços, caracterizada pelo crescimento do número de trabalhadores especializados na prestação de serviços de diferentes tipos (serviços pessoais, comunicações, lazer, atividades culturais e turismo), que não se agrupam de forma suficientemente homogênea a ponto de viabilizar uma representação sindical. Admite-se que pode ser possível viabilizar a existência de um sindicato para um grupo específico de prestadores de serviços, mas tal sindicato teria sua ação de tal maneira segmentada que veria comprometido seu poder reivindicatório.

A transformação das relações de trabalho no capitalismo flexível que levou à diminuição da força do sindicalismo está relacionada evidentemente à globalização, que afetou todos os 
modelos sindicais conhecidos. Todos esses modelos estão em crise, buscando alternativas para se adaptar a uma nova realidade político-econômica. Nesse processo, as diferenças entre os sindicatos residiria no ritmo dentro do qual as mudanças internas estariam sendo realizadas, e não na direção dessas mudanças (Rodrigues: 1999), que apontariam, todas elas, para uma adaptação à globalização, para a qual a "lei do mercado", de abrangência mundial, reinaria soberana.

Sobre este aspecto vale lembrar o que nos diz Gorz (2003), ao criticar os discursos dominantes hoje que fazem crer que a esfera do econômico (em que se insere o mercado) está acima das demais e, portanto, nenhuma ação das esferas política e cultural surtiria efeito sobre a primeira. Desta forma, tais discursos construíram fortemente a idéia de que apenas as decisões econômicas (que pressupõem a obediência às leis do mercado) podem promover uma vida em sociedade em condições materiais favoráveis, o que, para o autor, é uma contradição:

O mercado é fundamentalmente o lugar onde se afrontam indivíduos dispersos perseguindo cada qual seu próprio interesse. Mercado e sociedade são fundamentalmente antinômicos. O direito de cada um a buscar soberanamente sua própria vantagem implica que nenhum constrangimento nem nenhuma restrição lhe seja imposta em nome de um "interesse superior da sociedade" ou de valores transcendentes. A "sociedade de mercado" é uma contradição de termos: ela deve supostamente resultar da luta de cada um contra todos.

A crença em uma vida melhor promovida através da supremacia das leis de mercado levou, via globalização, à abertura das economias nacionais a um mercado mundial. Isto significou, na prática, nenhuma melhora na qualidade de vida da imensa maioria da população mundial e, pior, a perda do controle político da economia. Assim é que a força “irresistível” do mercado tem se imposto aos indivíduos, aos povos, aos estados nacionais, sem oferecer a realização do sonho de uma vida melhor para todos. Ao contrário, os abismos se aprofundam. 
No que se refere especificamente ao mundo do trabalho, o que se vê (e em escala mais alarmante nos países pobres) é o aumento do número de pessoas que sobrevivem na informalidade, sujeitando-se ao trabalho precarizado e à sua instabilidade intrínseca ${ }^{27}$.

É uma realidade da qual o sindicalismo, em suas diferentes formas, não pode dar conta, pois dela se originam os fatores que historicamente mais o têm prejudicado: automação e informatização, desemprego, terceirização, trabalho precarizado, diminuição ou desaparecimento de áreas de atuação em que os sindicatos eram fortes e fragmentação dos interesses das classes trabalhadoras.

Rodrigues (1999), embora constate haver um recuo do sindicalismo na medida em que avança a desindustrialização ${ }^{28}$ (processo próprio ao crescimento da sociedade de serviços, globalizada), sugere três alternativas possíveis (e não excludentes mutuamente) para a revitalização do sindicalismo no Brasil e no mundo, uma vez que sua sobrevivência poderia, ainda, de alguma forma, assegurar um certo equilíbrio de forças entre capital e trabalho: (i) focar-se sobre os novos grupos profissionais nas áreas do mercado que mais têm se expandido, ou seja, de assalariados suscetíveis de sindicalização nos setores mais modernos da economia; (ii) persistir nos lugares em que as técnicas de fabricação e as vias de obtenção de vantagens salariais e de benefícios sofreram pouca influência da economia globalizada, e até mesmo convivem com esta última; e (iii) conquistar e manter posições fortes nos segmentos produtivos que foram “modernizados” pelas novas práticas econômicas, que já possuíam um sindicalismo bem implantado e mantêm uma tradição associativa. No entanto, para o mesmo autor, as três alternativas têm pouca probabilidade de ocorrer na prática. A alternativa (i) é pouco provável porque em tais grupos profissionais

\footnotetext{
${ }^{27}$ Em relatório da Organização Internacional do Trabalho (OIT), lançado no Brasil em 18/11/2004, em evento realizado na FEA-USP, intitulado Segurança econômica para um mundo melhor, conclui-se que a segurança econômica promove o bem-estar pessoal, a felicidade e a tolerância, além de estimular o crescimento e contribuir para a estabilidade social. O relatório contém dados de países que representam 85\% da população mundial e adverte que a segurança econômica está fora do alcance da grande maioria dos trabalhadores do mundo. Cerca de três quartos dos trabalhadores vivem em condições de insegurança econômica. Essa realidade contribui para criar um mundo marcado pela ansiedade e pela violência. Apenas 8\% dos trabalhadores vivem em países ricos, nos quais é possível encontrar condições favoráveis na área de segurança econômica (fonte: Agência USP, 11/11/2004).

${ }^{28}$ Lembramos que o sindicalismo em geral ainda está fortemente moldado de acordo com os interesses dos trabalhadores das fábricas da era do capitalismo industrial, período em que se estruturou.
} 
(em geral das áreas de serviços pessoais, comunicações, lazer, cultura e turismo, conforme relacionado acima) a organização sindical tem mostrado pouca capacidade de implantação; a alternativa (ii) confinaria o sindicalismo a atividades produtivas do século XX em pleno século XXI, o que fatalmente o levaria a sua completa extinção; a alternativa (iii), por seu turno, restringiria a atuação do sindicalismo a um número extremamente limitado de profissionais, ou seja, aos núcleos estáveis altamente especializados das organizações de ponta $^{29}$. O sindicalismo se transformaria em um sindicalismo de minorias, por si já detentoras de maior poder de organização e negociação, o que tornaria a ação sindical inútil.

Gorz (2003) propõe uma quarta alternativa para o sindicalismo, inovadora pois o insere em uma perspectiva econômica nova. Por um lado, tal perspectiva busca integrar as esferas econômica, política e cultural, numa tentativa de restabelecer a conexão trabalho-vida para a grande massa de trabalhadores, e por outro visa reverter o principal sintoma da perversidade do capitalismo flexível, que consiste em arregimentar massas cada vez maiores de trabalhadores em situação precária e formar grupos cada vez menores e mais privilegiados de trabalhadores altamente especializados, que constituem os núcleos estáveis das organizações e têm se consolidado como os novos detentores do poder na forma mais atual do capitalismo, em que o Estado-provedor tende a intervir cada vez menos. Tal alternativa consiste em oferecer ao sindicalismo uma nova bandeira por que lutar: a redução da duração do trabalho, com manutenção de ganhos e re-estabelecimento de relações duradouras.

Gorz cita Glotz (1987) ${ }^{30}$ para ilustrar em que medida esta é uma boa alternativa:

[...] a esquerda européia tem a seu alcance uma utopia concreta que poderia mobilizar milhões de pessoas: a redução da duração do trabalho. Uma redução da

\footnotetext{
${ }^{29}$ Mundialmente observa-se a formação de grupos de profissionais altamente capacitados em posições de controle e gestão nas instituições onde atuam. Tais profissionais são bem remunerados e estáveis e constituem o que se chama de núcleo estável da organização, em contrapartida ao crescente contingente de prestadores de serviços de todo o tipo, ligados à instituição por contratos provisórios, mal remunerados, sem nenhum tipo de garantia ou benefício, e que substituem os antigos funcionários regularmente contratados em tempo integral segundo a legislação trabalhista em vigor.

${ }^{30}$ Peter Glotz, Die Malaise der Linken, Der Spiegel, 51, 1987, apud Gorz:2003.
} 
duração do trabalho concebida não apenas como o instrumento tecnocrático de uma repartição mais justa do trabalho, mas como a via a ser tomada em direção a uma sociedade diferente, que ofereça às pessoas mais tempo disponível. A oportunidade histórica que nos é oferecida nunca antes se apresentou na história da humanidade: fazer de tal modo que o tempo que cada um dispõe para sua busca de sentido seja mais importante que o tempo que precisa para seu trabalho, suas recreações e seu repouso. A esquerda não tem mais nenhum objetivo? Pois eis um. E não no papel, mas naquilo que já é o desafio das lutas sociais... Deve ser possível fazer da luta que levam os operários metalúrgicos alemães por uma redução sistemática da duração do trabalho sem perda de salário o tema de toda esquerda européia; fazer disso não uma questão particular de política social, mas o campo de uma empreitada maior, de caráter político, cultural, societal. Uma nova política do tempo: não um desafio particular de luta de uma categoria, mas uma idéia humanista que transcende as clivagens sociais.

A implantação de uma nova política do tempo, que constituiria o novo paradigma do mundo do trabalho pelo qual lutariam os sindicatos, não é algo fácil, ainda mais se considerarmos que não é consensual o hipotético sucesso de tal empreitada. Trabalhar menos para que todos trabalhem é uma boa causa por que lutar, mas os meios de realização deste grande objetivo não são claros.

Em um país como o Brasil, bem aquém da realidade européia em todos os aspectos que se referem ao mundo do trabalho, a distorção dos termos do novo paradigma não demorou a ocorrer e sua prática alheia à idéia original tornou-se comum. A redução da duração do trabalho em fábricas ocorre aqui sem manutenção de ganhos, sem restabelecimento de vínculos duradouros e, antes de tudo, está muito longe de visar a algum tipo de reconexão trabalho-vida, discussão que passa à margem dos setores econômicos. A redução da jornada de trabalho nos moldes brasileiros em nada contribui para uma transformação mais profunda do mundo do trabalho. Restringe-se a minimizar perdas de capital e evitar grandes demissões, o que é visto pelos sindicatos brasileiros como uma grande conquista. As necessidades materiais e a instabilidade econômica são tamanhas em nosso país que a simples manutenção das condições atuais passa a significar um ganho. Observa-se ainda que os próprios sindicatos brasileiros, inclusive os que ainda sustentam um certo poder de fogo, apóiam acordos e realizam negociações que não vão na direção da melhora das condições de trabalho de seus associados. Desta forma, os sindicatos brasileiros têm de fato realizado o oposto do que se propuseram a fazer desde o início, e é isto que pode, mais do 
que tudo, precipitar sua desarticulação total: apóiam o capital, legitimando suas práticas, a pretexto de que esta seria a única saída para garantir o emprego.

Tudo indica que não é através de uma representatividade sindical, via discursos sindicais, que a voz do trabalhador brasileiro encontrará eco. De fato, os discursos sindicais brasileiros em geral têm se ocupado fortemente de construir sentidos positivos sobre si mesmos, de modo a garantir sua subsistência. O foco de seus esforços tem sido representarse a si próprios, o que em si descaracteriza tais sindicatos enquanto tais.

O discurso jurídico trabalhista - a despeito de suas contradições que nascem do fato central de constituir-se como discurso de poder, como se verá adiante - pode significar o local oficial de expressão da voz do trabalhador, embora tal representatividade esteja longe de ser completa. O discurso jurídico trabalhista brasileiro, uma vez compreendido como discurso do direito de solidariedade (sobre isto trataremos no capítulo seguinte), poderá abrir-se à revisão de suas próprias práticas e ter suas construções textuais transformadas de modo a se tornarem de fato representativas. $\mathrm{Na}$ análise que faremos no capítulo 5, apontaremos em que aspectos, lingüisticamente, o discurso jurídico trabalhista no Brasil ainda não incorporou sua vocação para a paz social em prol de uma sociedade mais justa e solidária, na qual os trabalhadores pudessem encontrar sentido para suas vidas dentro e fora do mundo do trabalho. 
A REGULAÇÃO JURÍDICA DO TRABALHO 


\section{A REGULAÇÃO JURÍDICA DO TRABALHO}

Pensar sobre o Direito, em qualquer de suas ramificações, pressupõe pensar, antes de tudo, sobre dois conceitos de base: o conceito de justiça e o de sujeito de direito (este último condição para a existência do primeiro). A idéia de justiça está diretamente ligada à dimensão política de qualquer sociedade. De uma perspectiva democrática (que é a que nos interessa nesse trabalho), por dimensão política entendemos o conjunto de saberes postos em prática por um grupo social para que a vontade que cada membro desse grupo tem de viver em conjunto de forma organizada possa consolidar-se. O conceito de justiça constituise como aquela parcela dos saberes mobilizados que irá garantir à sociedade a duração e a estabilidade do conjunto dos saberes que a constituem politicamente. Dessa forma, a justiça garante a estabilidade política, estando ambas - política e justiça - intimamente imbricadas. Evidentemente, tal construção não se faz de forma homogênea e sem conflitos. Coerentemente com nossa formação como analistas do discurso, compreendemos que a heterogeneidade é constitutiva deste esforço, sendo a responsável pelos confrontos necessários à prática política democrática. A justiça, assim, surge como valor ético específico, atravessado por contradições próprias às suas condições de produção, mas eixo relevante, senão único, para a projeção e a garantia da paz pública (ver Ricoeur, 1995).

O que é justo, ou a que ordem deverá se fazer justiça, é algo que as sociedades determinam para si mesmas a partir de referências culturais que lhe são próprias - evidentemente de forma heterogênea e muitas vezes antagônica. De modo geral, conforme Ricoeur (1995:38), baseando-se no pensamento de John Rawls: “L'apllication de la règle de justice aux interactions humaines suppose qu'on puisse tenir la société pour un vaste système de distribution c'est-à-dire de partage de rôles, de charges, de tâches, bien au-delà de la simple

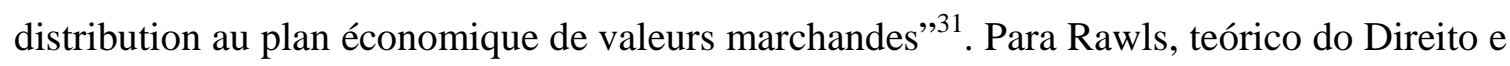
pensador da relação coação-liberdade, que interessa à justiça, tal distribuição significa dar a cada qual o seu, em sentido amplo, segundo valores próprios a cada cultura. Nessa direção, segundo Ricoeur, o face a face da justiça não é o "tu" identificável pelo rosto, mas cada

\footnotetext{
${ }^{31}$ A aplicação da regra da justiça nas interações humanas supõe que se possa considerar a sociedade como um vasto sistema de distribuição, isto é, de partilha de papéis, cargos, tarefas, muito além do plano econômico de valores materiais.
} 
qual enquanto terceiro ${ }^{32}$, destinatário de uma parcela do bem-comum. A justiça visaria sempre a um Outro, símbolo do bem-comum definido socialmente. Considerando-se que este Outro é sempre atravessado por diferentes vozes, o desafio constante da justiça é “manter a isenção” e buscar no Outro o que é comum.

Constituem-se, assim, na diversidade, os diferentes sistemas de Direito, com suas especificidades e suas contradições. Tais sistemas, permeáveis às mudanças, variam não apenas no espaço, mas também no tempo. Simultaneamente perpetuadores de valores tradicionais e implementadores de mudanças sociais, os sistemas jurídicos se alternam e se reciclam, imbuídos em sua prática jurídica pelas diferentes vozes que ecoam nos discursos que produzem.

Como o conceito de justiça se articula com o conceito de sujeito de direito? De acordo com Ricoeur (1995), referindo-se ao pensamento de Hannah Arendt, compreender a dimensão política de qualquer sociedade implica compreender que o poder político se organiza em diferentes níveis de poder, ou diferentes poderes, que estariam em continuidade com o poder que caracteriza o homem capaz. O homem capaz é capaz justamente porque dispende esforços buscando agregar sua vontade à vontade comum (trata-se de um agregar polêmico), admitindo a necessidade da hierarquia de poder. Este sujeito capaz é o que se chama sujeito de direito, que é condição de existência do conceito de justiça. Elucidemos, pois, o conceito de sujeito de direito, começando por citar Ricoeur (1995), que busca responder à pergunta: quem é o sujeito de direito?

Nous avons dit d'abord que le sujet du droit est le même que le sujet digne de respect et que ce sujet trouve sa définition au plan anthropologique dans l'énumération des capacités attestées dans les réponses que nous faisons à une série de questions en qui? culminant dans la question: à qui l'action humaine peut-elle être imputée? Puis nous avons donné une seconde réponse, selon laquelle ces capacités resteraient virtuelles, voire avortées ou refoulées, en l'absence de

\footnotetext{
${ }^{32}$ Observe-se que TU e ELE (terceiro) utilizados nesta concepção diferem de TU e ELE utilizados em nossa análise (como se verá adiante). Neste ponto, importa compreender a concepção de Rawls para quem enxergar cada qual enquanto terceiro garante, em uma visão idealista do Direito, a máxima isenção nos processos decisórios da justiça (todos - ELES e cada qual - devem ter sua parte garantida na distribuição dos papéis e tarefas sociais).
} 
mediations interpersonnelles et institutionnelles, l’État figurant parmi ces dernièrs [...]. (pp. 38-39) ${ }^{33}$

O que nos interessa particularmente nesta citação é a segunda resposta fornecida por Ricoeur, segundo a qual a noção de sujeito de direito só ganharia sentido (e mesmo existência) se o sujeito de direito puder ser visto em relação com demais sujeitos e/ou instituições. Ganha corpo a noção de sujeito de direito que será incorporada à análise que se fará e que pressupõe sempre sujeitos em relação.

A primeira noção descrita nos remete a certa tradição liberal segundo a qual o indivíduo precede o Estado. Tal noção atribui ao sujeito direitos naturais e inalienáveis pelo simples fato de tal sujeito ser um homem, cabendo ao Estado garanti-los. De acordo com tal noção, a associação do sujeito a outros indivíduos seria aleatória e revogável. A segunda noção, por sua vez, pressupõe que um indivíduo só se torna sujeito de direito no corpo da sociedade, não apenas no âmbito restrito das relações interpessoais, como também e fundamentalmente no âmbito das relações institucionais (em que a ação do sujeito é ampliada, projetando-se em esferas de poder de níveis superiores). Mais do que isso, sua pertença ao corpo social de modo institucionalizado é a condição necessária para seu desenvolvimento como homem e como sujeito de direito. Afirma Ricoeur (1995):

Le citoyen issu de cette médiation institutionnelle ne peut que souhaiter que tous les humains jouissent comme lui de cette médiation politique qui, s'ajoutant aux conditions nécessaires relevant d'une anthropologie philosophique, devient une condition suffisante de la transition de l'homme capable au citoyen réel. (p.40) ${ }^{34}$

O sujeito de direito, portanto, é simultaneamente sujeito portador de direitos inalienáveis e sujeito a quem se atribuem direitos e deveres na medida em que tal sujeito interage interpessoal e institucionalmente na sociedade onde vive, sendo a mediação institucional

\footnotetext{
${ }^{33}$ Dissemos primeiramente que o sujeito de direito é o sujeito digno de respeito, e que esse sujeito encontra a sua definição no plano antropológico na enumeração das capacidades atestadas pelas respostas que dávamos a uma série de questões relativas a “quem?”, culminando na questão: a quem pode ser imputada a ação humana? Demos depois uma segunda resposta, segundo a qual essas capacidades permaneceriam virtuais, e mesmo abortadas ou recalcadas, na ausência de mediações interpessoais e institucionais, estando o Estado entre estas últimas [...].

${ }^{34} \mathrm{O}$ cidadão nascido desta mediação institucional só pode desejar que todos os homens gozem como ele dessa mediação política que, juntando-se às condições necessárias que relevam de uma antropologia filosófica, se torna uma condição suficiente para a transição do homem capaz para o cidadão real.
} 
essencial para a caracterização da cidadania. Poderíamos, em síntese, assim definir o sujeito de direito: é aquele que, admitindo a necessidade das relações interpessoais e institucionais para sua configuração, agrega seus esforços à vontade comum para a consolidação de direitos inalienáveis a cada qual e para a consolidação da atribuição de direitos e deveres a cada um enquanto ator social.

Como já foi dito, para que um tal sujeito de direito seja possível, é preciso que consideremos tal sujeito antes de tudo como indivíduo capaz. A noção de capacidade (conforme a define Ricoeur, 1995:30) é "le référent ultime du respect moral et de la reconnaissance de l'homme comme sujet de droit” ${ }^{35}$. O sujeito capaz, assim, é aquele a que chegamos ao procurar responder à pergunta “quem é o autor da ação?”, ou ainda “quem é aquele que fala?”36. Apenas um sujeito capaz de designar a si mesmo como autor de uma ação pode responder a tais perguntas. Desta forma, é imprescindível que aquele que pergunta possa ao mesmo tempo identificar-se como EU, ou, dito em outras palavras, possa reconhecer-se a si mesmo como sujeito capaz. Apenas um sujeito que se auto-designa EU pode realizar a tarefa ulterior de atribuir direitos e deveres a si mesmo e aos outros.

Esta reflexão nos remete às preocupações centrais da pragmática. Num primeiro momento, pode-se criticar a visão de sujeito descrita no parágrafo anterior, que traria embutida em sua concepção a noção de indivíduo como uma espécie de centro do qual emanariam as ações discursivas. De fato, para efeito deste estudo, consideramos a imagem do sujeito como centro emanador de atos de fala apenas parcialmente coerente com o que se observa na prática discursiva. Através do diálogo entre Pragmática e Análise do Discurso, como vimos em capítulo anterior, entendemos como sujeito aquele que enuncia (auto-designando-se “EU”), ao mesmo tempo em que não enuncia sozinho. O sujeito capaz, discursiva e

\footnotetext{
${ }^{35}$... o referente último do respeito moral e do reconhecimento do homem como sujeito de direito.

${ }^{36}$ Vale adiantar um pouco do que será visto na análise, observando que no discurso jurídico trabalhista a resposta à pergunta “quem” é ambivalente. O sujeito discursivo trabalhador, em princípio o autor da ação trabalhista, só o é do ponto de vista dos mecanismos burocráticos que instauram a ação no âmbito legal. De fato, desde o início do processo o sujeito trabalhador delega seus esforços discursivos ao seu representante, ou seja, o sujeito advogado trabalhista. Se procurarmos responder à pergunta “quem fala?” no mesmo discurso, a resposta imediata será: o advogado e o juiz. O sujeito trabalhador fala apenas indiretamente, por delegação de sua palavra. Nesse sentido, a mediação institucional da Justiça do Trabalho, essencial para a caracterização da cidadania, deixa de exercer seu papel. Dito de outro modo, o trabalhador na relação com a Justiça do Trabalho não pode ser plenamente caracterizado como cidadão.
} 
juridicamente, é aquele que reconhece em si mesmo o sujeito que fala e percebe-se como sujeito histórico, atravessado pelas vozes de seus Outros.

A noção de capacidade só pode ser plenamente aplicada ao sujeito ambivalente, que traz em si as vozes do OUTRO. A atribuição dos direitos e deveres sociais, decorrente da aplicação da noção de capacidade, só se realiza entre sujeitos constitutivamente heterogêneos. Afinal, como saber o que atribuir - e a quem - se não se reconhecer profundamente a real presença do OUTRO, não como entidade externa, quando não distante, mas como pólo constitutivo necessário ao constante diálogo que constrói os laços sociais? Como realizar justiça se o OUTRO não puder ser visto como parte de cada um e do todo social? A justiça irá irremediavelmente arcar com as dificuldades imensas de articular constantemente com os limites fluidos entre os sujeitos, limites tais marcados lingüisticamente pelas vozes em discurso (ou pelos interdiscursos). Articular tais limites permite que a justiça se faça lá nos pontos em que as fronteiras mais se misturam, pontos nodais dos atritos em discurso e na vida social. A justiça só se faz se seus mentores considerarem o OUTRO como sempre implicado.

Importa ainda assinalar, igualmente com base nas reflexões de Ricoeur (1995), que o sujeito capaz só se constitui mediante a tripla articulação entre sujeitos capazes: EU, TU e ELE, este ELE compreendido aqui como CADA QUAL, ou seja, o conjunto da sociedade representada pelo sujeito institucionalizado e pelas instituições. Cada indivíduo desta tripla articulação pode, em algum momento, designar-se EU diante de um TU para negociar direitos e deveres. Este TU, assim, pode em momento seguinte designar-se EU. O processo discursivo que se desenvolve só se desenvolve porque é necessariamente mediado por ELE / CADA QUAL, que representa o bem-comum e, por isso mesmo, estrutura as relações ${ }^{37}$.

\footnotetext{
${ }^{37}$ Mais uma vez, cabe adiantar considerações feitas na análise seguinte. Observe-se que a relação triádica que se estabelece no discurso jurídico trabalhista é de ordem paralela: EU e TU são respectivamente o sujeito trabalhador (representado por advogado trabalhista) e o sujeito empregador (pessoa jurídica representada igualmente por advogado trabalhista). O ELE estruturante é a instituição jurídico-trabalhista, representada pela figura do juiz, que engloba a instituição enquanto materialidade através da qual os diferentes processos tomam corpo (hierarquia, funcionários, edifícios, estrutura de comunicação, etc) e as formações discursivas predominantes. A análise lingüístico-discursiva realizada (realizada em textos concretos pertencentes aos gêneros centrais que compõem um processo trabalhista, compreendido como unidade discursiva) nos mostra, no entanto, que a tríade apreensível nos textos é de outra ordem. O EU trabalhador apresenta-se de fato como ELE, que não corresponde ao ELE estruturante proposto por Ricoeur. Observamos uma nova categoria em
} 
Este ELE / CADA QUAL é sempre institucionalizado, sendo a instituição Direito sua representação máxima na ordem social. O Direito é, assim, a justiça institucionalizada em determinada sociedade, tanto no que se refere às teorizações sobre o justo como no que se refere às práticas que implementam e fazem valer a justiça instituída.

Reforçamos aqui nossa concepção de que as instituições são sempre perpassadas por contradições que lhe são próprias, o que inclui a instituição Direito, compreendida como instituição máxima promotora de justiça. O Direito constrói-se procurando equacionar as contradições a fim de ser de fato representativo do bem-comum. A própria noção de bemcomum (imprecisa no mais das vezes, porque mais aberta à hetorogeneidade) é ponto de conflito no discurso jurídico, que procura incorporar o que a noção traz de novo sem desvirtuar o que considera inquestionável em determinado momento sócio-histórico.

Cabe ao Direito, enquanto instituição máxima promotora de justiça, firmar-se enquanto tal consolidando a figura do sujeito capaz, de modo a que este se torne sujeito de direito e cidadão pleno. Ao consolidá-lo, reconhece-o e garante seu valor e lugar sociais. O sujeito de direito, desta forma, abarcado institucionalmente, torna-se sujeito do discurso jurídico (incluindo o trabalhista) e co-enunciador de sua fala (sempre de maneira autorizada pelo dito discurso, como se detalhará na análise). O sujeito trabalhador, foco desta tese, ascende a um estatuto privilegiado na hierarquia de poder ao articular-se como co-enunciador do discurso jurídico trabalhista, mas tal articulação nunca se dá de forma plena, pois o sujeito trabalhador não se auto-designa "EU”" nos textos oficiais. Nesta pesquisa, trataremos de mostrar como tal articulação não é isenta de contradições.

\subsection{A tradição do Direito: foco no passado}

A base filosófico-ideológica que sustenta o Direito tem sido basicamente a mesma no decorrer dos séculos, desde que foi definitivamente instituído pelos romanos praticamente dois mil anos atrás. Sobre tal base, alinhada ao paradigma objetivista de Aristóteles, erigiuse uma ciência do Direito idealista, para a qual as categorias são construídas por

que podemos enquadrar o ELE trabalhador, que escapa à teorização feita pelos pensadores do direito estudados. 
propriedades necessárias e suficientes, o que confere autonomia aos seus conceitos, que se petrificaram e continuam essencialmente petrificados durante todos estes séculos.

Em outras palavras, há para o Direito um sentido de sociedade ideal, baseado em outro ideal - o de uma coletividade "naturalmente” solidária, para a qual todos estariam ou deveriam estar dispostos a contribuir em nome do chamado bem-comum, que ainda tem sido tratado como abstração idealista. É em função deste idealismo que obscurece as contradições sociais que ainda é bastante difícil para o Direito atuar abarcando em seus pressupostos as contradições crescentes de que são "vítimas” as sociedades complexas de hoje. Como foi dito anteriormente, a noção de bem-comum é heterogênea e levar isto em conta é a condição para que as transformações necessárias ocorram na ciência jurídica. A questão que nos interessa aqui, portanto, é constatar que a heterogeneidade e o conflito de interesses nessas sociedades não têm sido devidamente absorvidos pelo Direito, que se mantém essencialmente como ciência positiva, avesso a contradições sociais.

As abstrações idealistas tradicionais no Direito constituem alimento para a memória social e discursiva em prol da perpetuação do que foi consolidado pelo Direito em séculos. Esta imagem do passado, projetada em práticas (inclusive discursivas) que podem ser consideradas até mesmo anacrônicas, suscita no sujeito que recorre à Justiça o sentimento de segurança, amparo, e mesmo esperança, que se assenta na tradição. Simultaneamente, tais abstrações, ao consolidarem por um lado práticas que impedem ao sujeito de direito uma inserção mais incisiva no mundo jurídico, atestando uma vocação elitista do Direito (que estaria, em última análise, mais voltado à permanente consolidação do poder que lhe é próprio e menos à distribuição eqüitativa do bem-comum), acionam no sujeito a memória do ideal de justiça que não falha e lhe assegurará o que lhe é devido. Estas contradições estão na raiz da heterogeneidade do discurso jurídico, sendo por um lado causa de decisões judiciárias equivocadas (quando a diversidade não é devidamente levada em conta) e por outro garantia de estabilidade e perpetuação de uma instituição cuja simples existência é fundamental no processo de construção da paz social.

Em meio a tais contradições, que sofrem fortes coerções do discurso jurídico em prol de seu mascaramento, o Direito procura firmar-se enquanto instituição sobre o tripé formado pelos 
conceitos de: fato (social e histórico), norma e valor. Tais aspectos articulados formariam o sentido geral da palavra Direito. Por fato (social e histórico) compreendemos os atos praticados por sujeitos de direito, localizados num tempo sócio-histórico, que necessitam do crivo da justiça instituída. Norma é o conjunto formado por legislação e jurisprudência, registrado por escrito, que irá determinar - junto com os fatos arrolados por escrito e as provas - a motivação à decisão por parte do juiz. Valor se refere ao peso atribuído aos fatos e às normas que, ao circularem socialmente, adquirem uma especificidade não uniforme que é levada em conta pelo juiz no ato de decidir. De fato, tal atribuição de valor está ela mesma incorporada pelo juiz, que assim não julga como sujeito autônomo e indiferente ao contexto social em que exerce seu papel (neste ponto o discurso jurídico tende à abertura), embora deva cumprir a lei (neste ponto o discurso jurídico tende ao fechamento). As normas são afetadas, assim, pelo modo como circulam socialmente, não sendo possível, portanto, observar esta tríade de modo estanque. A tríade, assim, deixa entrever sua constituição heterogênea. Como diz Reale (1965), referindo-se à forma tridimensional do Direito: “o Direito consiste de normas, cuja compreensão não é possível sem se ter em vista a sua circulação social e os valores que nelas se realizam”. Esta impregnação que ocorre através das relações interpessoais e institucionais está na base da ação do Direito enquanto prática social e discursiva que tende a ser homogênea, mas que também não pode negar sua própria heterogeneidade.

Faria (1986), referindo-se às normas e seu papel, sintetiza bem o significado prático fundamental das contradições descritas acima:

Valendo-se de termos com enorme carga ideológica e com grande intenção legitimadora da ordem estabelecida, a ficção de um sistema normativo logicamente coerente e harmonioso é utilizada pelos legisladores para projetar um mundo objetivo de imagens - como, por exemplo, aquelas implícitas nos princípios gerais do direito, cujo papel é viabilizar o conhecimento retórico de tudo aquilo que é contingente. Funcionalmente, então, as normas procuram despertar a crença do homem comum, à medida que os princípios gerais do direito o induzem a admitir que todas as aspirações de todos os segmentos sociais estão legalmente protegidas. Assim, tais princípios fornecem ao homem comum um cenário jurídico no qual ele se vê em condições de obter a aprovação oficial para "seus direitos" sem a necessidade de tentar defendê-los por métodos que ameacem a estabilidade das instituições existentes. (pp. 19-20) 
O Direito Contemporâneo ${ }^{38}$, constituído no fim do século XIX, está apenas começando a grande empreitada de incorporar em seus pressupostos as contradições próprias à crescente complexidade das sociedades atuais. O que tem ocorrido nas humanidades em geral é a necessidade de se privilegiar "um conhecimento das condições do conhecimento" - como diz Castro Farias (1998), para que seus objetos de estudo possam ser constantemente retomados e as condições epistemológicas e sociais que tornaram possíveis determinadas experiências do mundo social sejam reavaliadas. O Direito enquanto ciência dentro das humanidades deve passar pelo mesmo desafio. Afinal, como diz Foucault ${ }^{39}$, uma prática é indissociável do tipo de racionalidade através da qual ela se reflete, se ordena e se finaliza, mas, a nosso ver, não indissociável a ponto de nublar a auto-crítica.

\subsection{O direito de solidariedade}

É justamente na transição para o Direito Contemporâneo, e talvez como base jurídicofilosófica determinante para a consolidação deste Direito, que se delineia o que os juristas chamam de direito de solidariedade, cuja característica central e grande desafio é promover dentro do Direito as transformações necessárias para que este abarque em seus pressupostos teóricos e práticos toda a questão das imensas transformações sociais ocorridas a velocidade crescente a partir do final do século XIX.

A grande ruptura deste período histórico em relação aos anteriores é caracterizada pelo rompimento da coerência entre representação e linguagem. Tal coerência, própria à Idade Clássica, articulava-se segundo o pressuposto de que mundo e conhecimento formavam uma espécie de sistema de semelhanças, em que o diferente não era considerado. A linguagem, assim, seria uma espécie de espelho do mundo, um mundo de iguais, um mundo idealizado. Tal ruptura já encontrava solo fértil no período em que se constitui o Direito

\footnotetext{
${ }^{38}$ O saber jurídico pode ser dividido em três grandes períodos, ou grandes epistêmes: O Direito Clássico, composto pelo pensamento grego e pelo direito romano; o Direito Moderno, constituído notadamente nos séculos XVII e XVIII, ao qual corresponderiam as práticas do individualismo jurídico; e o Direito Contemporâneo, constituído no fim do século XIX e início do XX, do qual faria parte o direito de solidariedade, conforme será visto a seguir.

${ }^{39}$ Ver Les mots e les choses, une archéologie des sciences humaines, Paris, Gallimard, 1966.
} 
Moderno, não por acaso a partir do Renascimento, culminando com Descartes, uma vez que data deste período histórico o fortalecimento de forças individualizantes, para as quais natureza e homem não mais se articulariam harmonicamente, mas sim antagonicamente. $\mathrm{O}$ homo faber de então, construtor de sua própria natureza, não tardaria a entrar em conflito com seus semelhantes, na disputa pelo poder em diferentes níveis, disputas tais que levaram à consolidação dos pactos ou contratos sociais. No século XX, o conflito entre coletivo e individual, ordem e desordem, autoridade e liberdade, autonomia e independência, entre outros, pressiona por transformações nas instâncias sociais de toda ordem, dentre as quais, evidentemente, o Direito.

No contexto emergente do Direito Contemporâneo, surge a noção de justiça social que, ao buscar se sobrepor a uma concepção individualizada de Direito própria ao Direito Moderno, para o qual a noção de contrato social era suficiente, lança as bases para a formação do paradigma do direito de solidariedade. Embora a noção de justiça social já estivesse em construção durante o século XIX, sob a forma de um OUTRO com o qual os discursos jurídicos majoritários de então dialogavam, está na organização política e sindical das classes operárias européias do final do século XIX a origem da consolidação da noção tal como a conhecemos hoje. A hipótese da justiça social tenta conciliar o coletivo e o individual, na medida em que considera ser a aspiração à liberdade individual associada à aspiração à igualdade social. Da mesma forma, considera a experiência jurídica algo imanente, e não mais transcendente como era próprio ao Direito Clássico e em boa parte ao Direito Moderno. E aqui entenda-se imanente como a experiência jurídica para a qual o todo social é um sistema de ação (Gurvitch:1931, apud Castro Farias: 1998). Esta visão da experiência jurídica busca projetar o Direito na história e no acontecimento, trazendo à tona o fato de que a ciência do direito havia se afastado muito da realidade histórica. Castro Farias (1998), referindo-se aos principais juristas que desenvolveram o direito de solidariedade - Hauriou, Duguit, Saleille e Gurvitch, e citando Gurvitch (1933), afirma:

Todos esses autores têm em comum a luta decisiva contra o individualismo jurídico. Eles tentaram, por vias diferentes, eliminar o voluntarismo jurídico, defender a destruição da velha noção de soberania estatal, demonstrar o papel subalterno do contrato e da lei na vida jurídica, dar lugar aos aspectos impessoais e impersonificáveis no domínio do direito, atribuir um papel fundamental aos corpos 
sociais não estatais, "foco de seus próprios direitos", ampliar a noção tradicional de direito positivo liberando-a de sua sujeição à vontade do Estado. Enfim, pretenderam "fazer triunfar a idéia do direito social", concebido, tanto no seu aspecto organizado quanto no seu aspecto inorganizado, como um "direito de pura integração”. (p. 127)

O discurso do direito de solidariedade apresenta-se, portanto, aberto à heterogeneidade, diferentemente do que ocorre com o discurso jurídico tradicional (clássico e moderno). O discurso do direito de solidariedade traz implicada uma prática jurídica em que “o um e o múltiplo se engendram reciprocamente” (Castro Farias: 1998):

O espaço social implica um movimento contínuo de participação interpenetrante do múltiplo no um e do um no múltiplo, que promove uma correlação indissolúvel do todo e de suas partes num processo de ação comunicativa. Esse sistema de "integração" pretende tornar possível a existência de cada grupo social como uma "totalidade imanente concreta e dinâmica, que não admite nem sua hipóstase numa entidade simples, nem sua dissolução num grupo de indivíduos dispersos, cuja única ação seria a submissão deles a uma mesma lei abstrata”. (p. 128 - citação de Gurvitch:1933)

O desenvolvimento do programa do direito de solidariedade girará em torno de três questões fundamentais, que se tornaram mecanismos jurídicos de gestão do social: (i) responsabilidade; (ii) a necessidade da adoção de uma abordagem extracontratual; e (iii) a questão sindical. Todas as três questões foram levantadas a partir de experiências concretas no mundo do trabalho na Europa do começo do século XX, em particular na França. Na época, a teoria jurídica tradicional condicionava a responsabilidade civil à existência da falta (por exemplo, o operário que sofresse acidente de trabalho precisava provar não ter tido culpa no ocorrido para que isto justificasse a amputação de responsabilidade à empresa empregadora). A mesma teoria considerava a vontade do Estado superior à dos indivíduos, o que significava isentá-lo de responsabilidades. Na perspectiva do direito de solidariedade, o Estado é considerado um conjunto de serviços públicos confiados aos governantes e a seus funcionários, tendo, portanto, uma missão social a cumprir: satisfazer a coletividade (Castro Farias, 1998:140). Data desta época o surgimento do Estado de seguridade, que passava a garantir aos mais pobres direitos mínimos para a devida sobrevivência. No âmbito do trabalho, isto significava admitir que a causa profunda de um acidente na fábrica 
era a exploração industrial, para a qual o contraponto mínimo necessário seria a garantia de um sistema de seguridade.

A idéia de contrato passa por profundas reformulações no mesmo período. A idéia que predominava (e ainda predomina, de fato, ao menos em nosso país), e que caracteriza a própria noção de contrato, é a de que as partes contratantes são iguais e suas vontades são livres. Esta idéia de contrato mostra-se completamente deslocada da realidade histórica em que:

A dinâmica da sociedade moderna caminhava na direção da diferenciação cada vez maior entre os indivíduos, e do aumento das trocas com a necessidade de efetuá-las num tempo cada vez mais curto. Nessa sociedade, onde os indivíduos são cada vez mais diferentes uns dos outros, onde as variações de forças e de fraqueza aumentam, não se pode mais falar de contrato entre dois contratantes, pois os indivíduos estão em situação completamente diferente; freqüentemente não se conhecem e não podem debater sobre as condições de vontade. Não haveria aí um contrato, pois existe um concurso de duas vontades que querem a mesma coisa, mas que são determinadas uma pela outra, ou seja, que não são iguais. (Castro Farias, 1998:149, referindo-se a texto de Duguit)

E, mais adiante, acrescenta Castro Farias, também citando Duguit:

Pode-se falar razoavelmente de um contrato de locação de serviço entre o empregador poderoso capitalista e o operário? O empregador fixa previamente e espontaneamente o salário, e o empregado aceita-o, mas por uma outra causa: o empregado o aceita e quer trabalhar porque quer viver. Aí não existe contrato.

O movimento sindical, por fim, revelou-se aos olhos dos juristas do direito de solidariedade como a manifestação mais evidente da ruptura por que passavam as relações de trabalho, que exigiam serem vistas sob nova perspectiva. Para tais juristas, não se podia mais ignorar a “questão social”, assim como não se podia mais negar o anacronismo de uma concepção tradicional de Direito e Estado. Para o direito de solidariedade, o movimento sindical constituía-se como instrumento regulador das relações entre mundo do trabalho e capital. Sua grande função seria a de promover a aproximação de indivíduos que, em meio à diversidade, teriam interesses e aptidões da mesma ordem. O sindicato, assim, agrega pessoas e as representa diante de outras instâncias no mundo do trabalho. 
Os juristas do direito de solidariedade consideravam inadequada a representação sindical nos moldes do direito tradicional, que instituiu a representação legal fundada sobre a idéia do mandato e da "estipulação para outrem". Por esta forma tradicional, criava-se uma personalidade jurídica que não correspondia à complexidade orgânica do sindicato e seus membros. Era preciso romper com a lógica individualista "que via na representação uma relação jurídica onde os atos do representante eram bem seus próprios atos, mas que tinham o mesmo efeito jurídico como se fossem aqueles do representado" (Castro Farias, 1998:179). Era preciso criar uma unidade entre o sindicato e os indivíduos. Teorias e tentativas de se desenvolver este tipo de representação aconteceram na Europa a partir do início do século XX. No Brasil, desconhecem-se formas similares que tenham de fato funcionado. Os sindicatos brasileiros jamais tiveram tal forma orgânica: em parte devido à forte intromissão do Estado nas práticas sindicais, em parte devido ao corporativismo sempre presente na esfera sindical brasileira.

Os esforços para construção de um sistema de justiça baseado na solidariedade em nosso país, tal como compreendida pelos juristas do direito de solidariedade, traduzem-se nos esforços para concretizar uma legislação trabalhista que protegesse os trabalhadores pobres e assalariados dos desmandos do capital. Tais esforços não nascem e morrem na era Vargas, como muitos ainda pensam, mas a antecedem em várias décadas e continuam a existir nos anos que a sucederam, permeados de contradições.

\subsection{O Direito Trabalhista no Brasil}

No final do século XIX e início do século XX, o discurso solidarista não passou totalmente despercebido no Brasil, em especial por intelectuais como Rui Barbosa, Tobias Barreto e Joaquim Nabuco. Castro Farias (1998) pinça algumas falas desses autores que atestam o fato:

Rui Barbosa não hesitou em negar o individualismo jurídico e em reconhecer que "as velhas cartas careciam de ser revistas, porque feitas sob o influxo dos princípios individualistas de 1789, insubsistentes diante da chamada socialização, que inflama 
o mundo inteiro”40. Rui Barbosa defendeu um vasto programa envolvendo questões sociais: casa de operários, instrução popular, higiene pública, acidentes de trabalho, trabalho de menores, horas de trabalho, seguro operário, higiene nas fábricas, condição das mães operárias, igualdade dos sexos perante o trabalho, salário mínimo, etc.

Da mesma forma, segundo Castro Farias, Tobias Barreto também defende a idéia de que “o direito é uma disciplina social, isto é, uma disciplina que a sociedade impõe a si mesma na pessoa de seus membros, como meio de atingir o fim supremo de todos - e o direito só tem este - da convivência harmônica de todos os associados”41.

Aos poucos o discurso da solidariedade expande no Brasil sua voz predominante, que diz da necessidade que as sociedades capitalistas modernas teriam de extrapolar a dicotomia entre liberalismo e marxismo. A sociedade seguradora, ou o Estado segurador, seriam a melhor expressão do discurso de solidariedade na busca da superação desta dicotomia. A democracia deveria estar então a serviço da sociedade e garantir este estado de coisas seria a grande missão social do Estado.

A contrapartida jurídica do discurso de solidariedade no Brasil (e mais especificamente do discurso jurídico solidarista) encontrou sua formulação teórica e prática na legislação trabalhista, único instrumento de seguridade social dos brasileiros, cujos primórdios datam já do período imperial, quando surgiram as três primeiras leis que atribuíam tratamento diferenciado às demandas relativas à prestação de serviços (respectivamente em 1830, 1837 e 1842). Em 1850, o Regulamento 737 determinou que demandas relativas a contrato de trabalho fossem apreciadas pelos juízes comuns, aplicando-se as normas comuns da organização judiciária da época.

Já na República, o Decreto 979 de 1903 facultou aos trabalhadores do campo a organização de sindicatos para defesa de seus interesses. Em 1907, no governo de Afonso Pena, são criados os primeiros órgãos jurisdicionais trabalhistas no Brasil: os Conselhos Permanentes de Conciliação e Arbitragem (Lei 1.637), no âmbito dos sindicatos, e com poderes

\footnotetext{
${ }^{40}$ Castro Farias cita o prefácio de Homero Pires à obra de Rui Barbosa, Teoria política, Rio de Janeiro, W.M Jackson Editores, 1964.

${ }^{41}$ Castro Farias cita Tobias Barreto em Questões vigentes, Sergipe, Edição do Estado de Sergipe, 1926.
} 
abrangentes para arbitrar todo tipo de divergência e contestação entre capital e trabalho. A lei acabou se tornando inócua, pois os sindicatos de então não se organizaram para compor internamente tais conselhos.

A constituição de 1891, a primeira da República, ao instituir a federação, atribuiu aos estados autonomia para a implantação de órgãos especializados em dirimir questões trabalhistas.

Em 1922, em meio à urgência de uma arbitragem justa, eficaz e abrangente, o ministro do Supremo Tribunal Federal, Augusto Viveiros de Campos, pediu a rápida instituição de órgãos permanentes de conciliação, aos quais fossem submetidas as questões relativas a demandas entre patrões e empregados. Pediu ainda a criação das Juntas Industriais, compostas por magistrados especiais assessorados por representantes de patrões e operários, que funcionariam como peritos para esclarecimento de natureza técnica. $\mathrm{Na}$ época, evidenciavam-se a crescente complexidade do mundo do trabalho, acentuadamente nas cidades que se industrializavam, a falta de conhecimento técnico das questões laborais por parte dos juízes e a necessidade de se poder contar com assessoria nesse sentido.

Em 1923, com base nas reivindicações de Campos, o Ministério da Agricultura, Indústria e Comércio instituiu, através do Decreto 16.027, o Conselho Nacional do Trabalho com três finalidades: ser órgão consultivo do Ministério em matéria trabalhista, funcionar como instância recursal em matéria previdenciária e atuar como órgão autorizador das demissões dos empregados que, no serviço público, gozavam de estabilidade, através de inquérito administrativo. Observe-se que em todo este percurso as garantias só passaram a existir através de um duplo movimento: o de que o não assegurá-las ameaçaria a ordem social e os interesses econômicos; e o de que um estado de seguridade era o que se esperava de um país moderno, preocupado com amenizar as dicotomias capital x trabalho e garantir a subsistência dos mais fracos. A constituição de inquéritos administrativos para autorizar demissões a partir de questões trabalhistas ligadas ao funcionalismo público (no início, ferroviários e marítimos; depois o restante do funcionalismo) mostra as duas direções do sistema jurídico que se implementava: por um lado, assegurar garantias ao trabalhador, em 
especial o sindicalizado; por outro retirá-las, se isto comprometesse interesses de ordem político-econômica.

O primeiro ato de Getúlio Vargas ao assumir o poder com a Revolução de 1930 foi criar o Ministério do Trabalho, desatrelando-o do da Agricultura, mas mantendo-o ligado ao da Indústria e Comércio, confirmando a tendência que apontava para um número maior de demandas trabalhistas nos centros urbanos. Isto não significava que no campo não houvesse demandas. Provavelmente, eram reprimidas pelo sistema patronal de origem escravocrata próprio à produção agrícola brasileira na época, ou dirimidas pelo patrão, sem arbitragem.

Em 1932 criam-se as Comissões Mistas de Conciliação (Decreto 21.396) para dirimir conflitos coletivos, que no início não impunham às partes uma solução, apenas as estimulavam a encontrar alguma, realizando acordo. Em última hipótese, o caso era remetido ao Ministério do Trabalho, que julgava. As comissões de conciliação estruturavam-se na dependência direta da estrutura sindical. No mesmo ano, criam-se as Juntas de Conciliação e Julgamento para conflitos individuais (Decreto 22.132) de trabalhadores sindicalizados, que podiam impor, mas não executar suas decisões. A execução cabia ao Departamento Nacional do Trabalho, que a requeria à Justiça comum, que tinha autonomia até mesmo para anular a decisão das Juntas. Em caso de suspeita de parcialidade dos julgadores, o caso voltava ao Ministério do Trabalho.

Na Assembléia Constituinte de 1934, após a revolução de 1932, Getúlio Vargas reconhecia ser imprescindível que se criasse uma Justiça do Trabalho que abarcasse os casos individuais (trabalhadores não sindicalizados). De fato, a constituição de 1934 cria uma Justiça do Trabalho, mas de caráter administrativo e ainda atrelada ao poder executivo.

Getúlio Vargas, ao outorgar a Constituição de 1937, fechando o Senado e a Câmara dos Deputados, alega justamente que tais medidas teriam sido necessárias, inclusive a adoção de um regime de exceção, a fim de fazer frente à resistência do Poder Legislativo à aprovação do Projeto de Lei referente à Justiça do Trabalho. Com isto, a Justiça do Trabalho é totalmente desatrelada do pouco que tinha de ligação com a justiça comum ou 
com o judiciário em geral, passando sua gestão a ser integralmente de competência do poder executivo, de acordo com o modelo fascista italiano. De fato, é o atrelamento ao executivo totalitário e o funcionamento meramente administrativo da Justiça do Trabalho que a relacionam ao modelo fascista, e não a raiz que a relaciona ao direito de solidariedade e ao discurso solidarista.

A política trabalhista de Vargas teve por objetivos principais reprimir os esforços organizatórios da classe trabalhadora urbana fora do controle do Estado e atraí-la para o apoio difuso ao governo. O governo estimulava, assim, apenas a sindicalização limitada e controlada pelo Estado, em especial nos meios urbanos. A estrutura da justiça do trabalho já nasce voltada para o trabalhador sindicalizado das cidades que se industrializavam, deixando de fora uma grande massa de trabalhadores rurais ou urbanos não sindicalizados. Do modo como foi configurada, a justiça do trabalho brasileira nasce em 1937 como aparelho do Estado, portanto passível de todo tipo de manipulação; enquanto atendimento às demandas crescentes de uma sociedade antiquada que clamava por justiça social, nasce como resposta possível.

Vários decretos regeram a constituição da Justiça do Trabalho até 1941, que funcionava basicamente através de um Conselho Nacional do Trabalho, oito Conselhos Regionais e trinta e seis Juntas de Conciliação e Julgamento. Em 1º de maio de 1943, Getúlio Vargas, através do Decreto-lei 5.452, promulgou a Consolidação das Leis do Trabalho (CLT). Se de um lado a promulgação da CLT atesta a vocação populista de seus autores, de outro atesta estar a formação da justiça trabalhista brasileira na esteira do discurso solidarista, implicitado, a nosso ver, em todo o percurso de lutas por implementação de políticas sociais mínimas, não apenas no Brasil ${ }^{42}$.

\footnotetext{
${ }^{42}$ Calil (2001) relaciona as datas de surgimento da Justiça do Trabalho na Europa:

Ano País Organismo jurisdicional Ano País Organismo jurisdicional

1806 França Conseils de Prud'hommes 1926 Alem. Arbeitgerichts

1893 Itália Probiviri

1919 Inglat. Industrial Tribunals

1926 Espanha Comitês Paritarios para Conciliación y Reglamentación del Trabajo

1931 Portugal Tribunais de Árbitros Avindores
} 
A Constituição Federal de 1946 transfere definitivamente a Justiça do Trabalho ao Poder Judiciário. Um pouco antes, dois decretos já contribuíram para tornar a Justiça do Trabalho órgão essencialmente judicante: o 8.737 de janeiro de 1946 retirava da Justiça do Trabalho sua alçada sobre questões previdenciárias; e o 9.797 de setembro do mesmo ano, editado pelo presidente eleito Gaspar Dutra, deu à Justiça do Trabalho uma estrutura judicial, que permanece até os dias de hoje:

Art. 94. O poder judiciário é exercido pelos seguintes órgãos:

(...)

V - Juízes e tribunais do trabalho.

Art. 122. Os órgãos da Justiça do Trabalho são os seguintes:

I - Tribunal Superior do Trabalho;

II - Tribunais Regionais do Trabalho;

III - Juntas ou juízes de conciliação e julgamento.

(...)

Art. 123. Compete à Justiça do Trabalho conciliar e julgar os dissídios individuais e coletivos entre empregados e empregadores, e as demais controvérsias oriundas de relações do trabalho regidas por legislação especial.

(Carta de 1946, promulgada em 18 de setembro de 1946)

A partir de então instituiu-se a formação da carreira de Juiz do Trabalho e a ampliação do mandato dos vogais (que a partir da Constituição de 1988 foram denominados juízes classistas) de dois para três anos. Cabia aos vogais, desde os primórdios da legislação jurídico-trabalhista brasileira, e depois incorporados à estrutura da Justiça do Trabalho, apoiar as partes em litígio como representantes das respectivas classes laborais do empregado e do empregador, contribuindo para a decisão do juiz com seu saber especializado do mundo do trabalho. Emenda constitucional de 1999 extinguiu a representação classista, considerada onerosa e inútil. Como diz Calil (2001):

Nos últimos anos, o instituto da representação classista vinha sendo alvo de inúmeras críticas. As principais delas calcadas no fato de ser dispendioso demais para os novos tempos que exigem enxugamento da máquina estatal e rigoroso controle do erário; e, principalmente, a perda de sua função. Sua criação e manutenção se justificaram pelo conteúdo de vivência que esses representantes de trabalhadores e empregadores trariam para somar-se à cultura jurídica do juiz togado, este, sim, versado em Direito. E, no princípio, mostrou-se eficiente; mas, atualmente, as exigências específicas para análise das demandas careciam de profunda erudição técnico-jurídica, afastando o processo do ramo de conhecimento 
empírico que os classistas traziam à Justiça do Trabalho e tornando, de fato, sua presença, como órgão jurisdicional, inútil.

A mesma emenda, no mesmo ano, substituiu as Juntas de Conciliação e Julgamento pelas Varas do Trabalho, com função idêntica. Cada Vara abrange pelo menos um município e possui um juiz singular. A cidade de São Paulo, devido a sua extensão, possui 79 Varas do Trabalho, que se distribuem em cinco fóruns.

Hoje o clima que permeia as discussões sobre o direito trabalhista brasileiro é de polêmica. Muitos são favoráveis à sua extinção, pelos custos que gera, propondo o encaminhamento das demandas jurídico-trabalhistas a outras áreas do sistema judiciário ou sugerindo a negociação direta entre as partes. Outros são favoráveis a reformulações na legislação trabalhista que torne menos onerosa a contratação de empregados, alegando que a carga tributária trabalhista é responsável pela diminuição da produtividade e perda de competitividade das empresas ${ }^{43}$. Outros ainda consideram a possibilidade de "adequar a lei trabalhista aos novos tempos”, procurando manter assegurados os direitos do trabalhador pobre e deixando abertas para negociações as garantias trabalhistas de categorias mais bem estabelecidas. Tais argumentos, de ordens aparentemente opostas, são de fato materializações de formações discursivas que se alinham a discursos liberais, que tendem a simbolizar o mundo estritamente a partir do fator econômico. Faltam esforços para localizar a polêmica no âmbito da história do desenvolvimento do discurso de solidariedade, de onde nascem as políticas sociais, nas quais se encaixa a justiça trabalhista.

É preciso esclarecer que a polêmica, tal qual se trava no Brasil hoje, está deslocada. Não se trata de modificar ou extinguir a justiça do trabalho, mas de ampliar as políticas sociais que se alinham ao discurso da solidariedade. Dentro ou fora da justiça do trabalho, o que falta é a construção de espaços sociais de representação institucional do trabalhador. Se o sujeito de direito é cidadão na medida em que é sujeito institucionalizado, e se o espaço

\footnotetext{
${ }^{43}$ Embora enuncie de um lugar de onde não se esperaria uma fala diferente da que se segue, é interessante conhecer, a esse respeito, a opinião do Sr. Ventuil Abdala, atual presidente do TST: "O produto interno bruto (PIB) cresceu 5,7\% no segundo semestre deste ano. Esse foi o melhor resultado da economia nacional desde 1996 e é uma prova de que não há necessidade de se reduzir os direitos trabalhistas para que a economia apresente bons resultados”. (Entrevista à Revista Agitação, publicada pelo CIEE, set/out de 2004)
} 
institucional do direito trabalhista (precário, a nosso ver) lhe for simplesmente arrancado, trata-se de encontrar os caminhos para tal representatividade, numa sociedade que se diz democrática e plural, mas que está de fato muito próxima de suas raízes históricas patriarcais.

Ampliar a discussão dessa maneira implica compreender a fundo o que é o discurso solidarista e o direito de solidariedade e de fato poder olhar o mundo a partir da perspectiva que tais discursos abrem. Assim, é preciso tomar cuidado para não cair em simplificações, que reduzem o direito social a uma política social do Estado, que simplesmente intervém na economia e cria artifícios para proteger os elementos mais fracos. Como diz Castro Farias, citando Gurvitch:

As práticas do direito social são mais profundas e complexas do que isso. Elas implicam um "pluralismo jurídico na vida real do direito, que é uma conseqüência do pluralismo de fato na realidade social"44.

E mais adiante:

O discurso do direito social não veria nos menos favorecidos economicamente e socialmente apenas beneficiários e destinatários de um Estado benfeitor. Ele supõe sobretudo atribuir aos interessados - grupos, classes ou indivíduos - um direito social próprio, com uma autonomia jurídica capaz de reivindicar e de controlar, e por conseguinte, com garantias de liberdade positiva capazes de atribuir aos grupos e aos indivíduos o papel de atores sociais ativos, possuindo a faculdade de se autogovernarem e de defenderem seus direitos. Assim, o direito social não se reduz somente a uma regulamentação de ajuda social do Estado e à distribuição de satisfações materiais; mais do que isso, ele implica uma autonomização da sociedade e um novo tipo de regulação social. (p. 271)

Trata-se, isto sim, em síntese, de repensar o direito trabalhista a partir de uma reformulação do papel de Estado benfeitor, que incluísse em suas propostas políticas a garantia do direito e a voz ativa do sujeito desse direito.

\footnotetext{
${ }^{44}$ Gurvitch, La déclaration des droits sociaux, New York, Editions de la Maison Française, 1944.
} 
Como procuraremos demonstrar na análise da representatividade da voz do trabalhador no discurso jurídico trabalhista, não se trata de suprimir a garantia do direito (que inclui o direito mínimo do trabalhador de mover o órgão jurisdicional a seu favor), ou limitá-la, nem tampouco de ampliá-la se isto puder impedir a autonomização do sujeito; trata-se de ampliar a garantia ampliando as formas de representação. O direito trabalhista brasileiro, tal qual está hoje, se por um lado garante direitos fundamentais (o que é positivo), por outro não garante a voz ativa dos sujeitos de direito, o que é palpável na superfície discursiva dos textos analisados.

\subsection{Discurso jurídico / linguagem jurídica}

Como dissemos, o discurso jurídico cria para o sujeito de direito um cenário jurídico no qual ele se vê em condição de obter a aprovação oficial para "seus direitos”, “sem a necessidade de defendê-los por métodos que ameacem a estabilidade das instituições existentes” (Faria, 1984).

Dentro deste quadro geral, o discurso jurídico, que inclui o discurso jurídico trabalhista, constrói-se tendo em vista a criação da obrigação de motivar uma decisão. Esta é sua razão de existir. Os textos dirigidos ao juiz, o decisor formal e representante da ordem instituída, serão redigidos tendo como pressuposto fundamental esta asserção. Para que a motivação à decisão ocorra, o discurso jurídico considera pressuposta a retidão dos argumentos. Se não fosse assim, a motivação para a decisão estaria comprometida, uma vez que não se decide bem (isto é, não se decide de acordo com a motivação construída na argumentação) sobre falsos argumentos, ou argumentos equivocados.

O discurso jurídico se orienta em prol da motivação à decisão e não propriamente em prol da decisão porque a decisão pode em princípio ser qualquer uma. Por outro lado, a motivação para a decisão vai exigir que os textos se construam em prol de determinada decisão, e não de outra. Além do que, não se poderia falar em uma orientação para a decisão pura e simples sem correr o risco de imprimir à figura do juiz um caráter de aplicador de leis, quase que à revelia dos textos construídos durante o processo. De fato, é o texto que conduz o juiz, motiva-o, numa direção. $\mathrm{O}$ ato de interpretar, essencial à decisão, é de certa maneira orientado desde o início do processo jurídico, isto é, desde a elaboração 
do primeiro texto oficial/legal produzido no processo e dirigido ao juiz, texto este que, no caso do processo jurídico trabalhista, é a petição trabalhista.

Esta direção que o discurso toma em prol da motivação à decisão é, a nosso ver, a principal característica do sistema de restrições semânticas do discurso jurídico (e do discurso jurídico trabalhista) e o eixo da direção argumentativa geral do discurso jurídico trabalhista, que é a luta pela obtenção do ganho da causa do trabalhador.

As restrições semânticas ocorrem em dois níveis: no primeiro, ocorrem as restrições que visarão manter na superfície discursiva o que é tradicional e caro ao Direito e às estruturas formais do sistema jurídico trabalhista. No segundo, ocorrem as restrições que irão moldar a forma de representação da voz do trabalhador e dos discursos do mundo do trabalho. Os dois níveis se chocam, daí a tensão entre efeitos monofonizantes e efeitos de abertura à polifonia própria aos textos e gêneros em questão. Ressalte-se que os textos e gêneros oficiais/legais têm sua construção fortemente coagida pelas restrições que tendem a apagar a voz do trabalhador.

O discurso jurídico, assim, manifesto nos textos de caráter jurídico dos mais variados gêneros, constrói-se valendo-se, por um lado, de estruturas e termos com grande intenção legitimadora das tradições do Direito (constituindo textos, portanto, preponderantemente homogêneos) e, por outro, de espaços de abertura à heterogeneidade, onde a voz do trabalhador e dos discursos vinculados ao mundo do trabalho rompe a hegemonia dos textos em graus diferentes de abertura, dependendo do gênero em questão. Os efeitos monofonizantes, bastante fortes na petição trabalhista, constroem os avanços da direção argumentativa geral dentro do campo jurídico trabalhista. A polifonia constrói recuos na direção argumentativa geral, entendendo-se por recuo o acionamento interdiscursivo dos Outros constitutivos do discurso jurídico trabalhista que também constroem a argumentação lingüística. O item 5.7 (A voz do trabalhador na cena enunciativa) aprofundará este ponto.

Vê-se que os textos produto do discurso jurídico trabalhista não são diferentes de outros textos, frutos de outros discursos, no que se refere à sua produção e ao seu processamento. Como evento comunicativo no qual estão presentes ações lingüísticas e sociais, é nele que o ser humano vivencia e constrói conhecimento, constituindo-se elemento intimamente 
vinculado ao seu contexto de produção e processamento e, portanto, determinado por condições históricas, de nível sócio-político-econômico e cultural.

Embora o texto jurídico se construa como unidade autônoma, aparentemente isenta das influências contraditórias do meio, esta construção deve ser apreendida como estratégia discursiva e não como fato em si. Ao criar o efeito de sentido de unidade, autonomia e univocidade, o texto jurídico apenas revela o quanto está alinhado ao paradigma idealista do discurso que o gerou. O leitor e o produtor de tais textos, ao interagirem através do texto, estão interagindo de acordo com o paradigma instituído pelo discurso, num único e mesmo processo em que aspectos lingüísticos e sociais se imiscuem para possibilitar a produção do sentido.

O texto jurídico trabalhista, assim, disponibiliza ao leitor o acesso a sentidos coerentes com o paradigma do discurso jurídico trabalhista. Ao alegar o que quer que seja em defesa de seu enunciador-trabalhador, o locutor-advogado simboliza determinada realidade, revestindo-a do caráter de verdade empírica (mas é de fato discursiva), com o objetivo de fazer o leitor (o juiz que deliberará sobre o caso) percorrer determinada direção argumentativa, e não outra, que levará a determinados sentidos, que motivarão a decisão do juiz de uma certa maneira. O juiz, evidentemente, ao ler a petição trabalhista, compreende-a a partir do paradigma adequado.

A perspectiva pragmática (como pano de fundo) e a perspectiva lingüístico-discursiva (sob a forma de uma análise do discurso fortemente marcada pela semântica global e pela semântica argumentativa, conforme vimos em capítulo anterior) podem assegurar uma compreensão mais profunda da produção de sentido no discurso jurídico trabalhista, em especial no que se refere à representatividade do sujeito trabalhador nesse discurso, ao apreender a interdiscursividade em suas manifestações lingüísticas.

4.5 Gêneros centrais do discurso jurídico trabalhista: petição, audiência, entrevista inicial

Nossa tese inicial, a partir da leitura das petições (e dos textos orais que as originaram e dos demais textos a elas relacionados), da conceituação que se esboçou sobre o que seja Direito, direito trabalhista, discurso e texto jurídico, e do referencial teórico lingüístico-discursivo a 
que nos referimos, é a de que as petições se constroem como unidades aparentemente estanques e unívocas. O ponto de vista predominante é o do locutor-advogado, que faz as vezes do trabalhador perante as instâncias que deverão fazer valer, ou não, o direito requerido. Tal locutor-advogado em geral não pertence à mesma classe social do trabalhador, ainda assim é através dele que o trabalhador fala.

O que, a nosso ver, chama a atenção e caracteriza as petições trabalhistas é a estratégia discursiva de se utilizar a voz do locutor-advogado, que se refere ao trabalhador em terceira pessoa, como ente alheio ao processo, evidenciando o jogo de forças central - e desigual que as sustentam. A voz do trabalhador não se manifesta por si, mas apenas e tão somente através da voz do locutor-advogado. Ao trabalhador não é dada a palavra sequer uma vez. A argumentação é tecida em nome dele e não por ele. O trabalhador ocupa o modesto lugar de terceira pessoa do discurso, aquela de quem se fala. $\mathrm{O}$ trabalhador aparece em tais textos como alguém a que se faz referência. Afora a menção de seu nome no início da petição, no decorrer do texto é designado por alguns termos-chave do discurso jurídico.

O sentido construído não se choca, em um primeiro momento, com a realidade social empírica, fora do texto, pois tal posição secundária, de coadjuvante discursivo, é a contrapartida da realidade empírica. A partir de nossa perspectiva discursivo-pragmática, fica evidente a não-autonomia lingüística de tais textos, embora, e contraditoriamente, o panorama social geral que o Direito busca construir pressuponha a noção de autonomia, não-relação. Felizmente, os textos traem-se a si mesmos revelando contradições que, estas sim, nos levam a sentidos mais ricos, inter-relacionados.

O gênero petição trabalhista é usado em situação bastante específica e estável, ou seja, no momento em que é requerida ao juiz a obtenção de um direito trabalhista ou seu cumprimento (petição inicial), e a cada solicitação feita no decorrer do processo, quando necessário. Sendo gênero estável, possui um formato consolidado, com poucas variações.

O cabeçalho constitui-se do endereçamento, seguido do número do processo, se se tratar de processo já iniciado. A seguir, é apresentado o requerente (para nós, o trabalhador), através de seu nome completo, em destaque, e seus dados, se for petição inicial. Esta apresentação faz-se sempre da mesma maneira, sob a forma de um pedido respeitoso ao juiz, instância 
representativa do poder constituído. As fórmulas cristalizadas, sintoma da assimetria na relação entre as parte, são as seguintes:

Exemplo 1: "FERNANDO MOREIRA MENDES ..... vem respeitosamente com amparo no artigo 884, parágrafo $3^{\circ}$. da CLT, tempestivamente impugnar a sentença...”

ou

Exemplo 2: “JOAQUIM FERREIRA DE LIMA,... vem propor reclamação trabalhista contra... pelas razões de fato e de direito a seguir aduzidas..."

Observe-se que o trabalhador pede, de forma alguma exige, não importa quão evidente seja seu ganho de causa. É o caso de nos perguntarmos, tendo em vista as operações de retextualização, em que ponto do processo se inicia tal posição discursiva. A própria origem do termo “petição” remete a esta relação desigual: petição vem do latim “petitione”, ato de pedir. O desnivelamento entre capital (poder instituído) e trabalho (requerente via locutor/advogado) se instala no início do texto, onde se explicita, e se mantém até o final. Aparentemente, o desnivelamento é contrabalançado pelo componente retórico da argumentação do locutor-advogado, que impõe a justeza da causa defendida. No entanto, ao mesmo tempo, a ênfase imposta revela qual ponta do binômio necessita de retórica afiada como arma para alcançar seus objetivos, evidenciando-se ser a mais frágil.

Ao trabalhador cabe atuar como não-pessoa no texto (conforme concepção clássica de Benveniste), ficando a cargo do locutor/advogado empreender o esforço discursivo. A posição passiva do reclamante/trabalhador é expressa em todo o texto através principalmente da ocorrência de certo tipo de anáfora, que se dá através de seleção léxica bastante própria que categoriza o trabalhador dono de seus direitos como trabalhador pedinte de direitos, conforme mostram os termos mais utilizados: "recorrente” $\mathrm{e}$ "reclamante".

Após a apresentação, ocorre a descrição do ocorrido, se necessário, seguida da argumentação, momento em que esforços discursivos são postos em prática a fim de se construir a direção argumentativa do texto. Importantes neste processo são os recursos de caráter aparentemente apenas retórico, como já mencionado, como o uso de palavras e 
expressões que provocam o efeito de sentido de indignação perante a injustiça em pauta com o objetivo de conduzir o leitor pela direção construída. O uso de “ora”, como em “Ora, E.Turma, ao indeferir a juntada de petição...o MMo. Juízo de primeiro grau praticou inadmissível cerceio de defesa" é um exemplo pertinente; ou ainda de adjetivos como o próprio "inadmissível” do trecho anterior, ou “inconformado”, como em "TADEU CAMPOS, ... inconformado ... com a r.sentença..., vem respeitosamente...”. Este efeito de indignação é na verdade um recuo na direção argumentativa geral, através do qual acionamse os interdiscursos do mundo do trabalho (ver item 5.7 adiante).

Finalmente, expõe-se de modo conclusivo a necessidade de acolhimento do pedido por parte do juiz, ao que se segue local e data e a assinatura do advogado, devidamente acompanhada de número de registro na OAB. O advogado assina sempre como procurador do reclamante (uso da sigla “pp”), o que, a nosso ver, apenas reforça lingüisticamente a posição secundária do trabalhador em processo que lhe diz respeito diretamente. A estrutura dos enunciados e o jargão árido próprio ao gênero acentuam tal distanciamento, uma vez que expressam uma linguagem que não se coaduna com a linguagem do trabalhador.

Do ponto de vista pragmático, o sentido da petição, como de qualquer outro gênero discursivo, não se produz em sua integridade sem se levar em conta o perfil social dos interlocutores e o contexto de produção dos textos. Em todo o processo trabalhista o locutor-advogado, em nome de seu representado (o trabalhador) tem por interlocutor a figura do juiz. O juiz representa o ideal de justiça e imparcialidade e, portanto, da busca do equilíbrio nas relações empregado $\mathrm{x}$ empregador. No entanto, trata-se de figura mais complexa, que o idealismo próprio ao Direito não pode escamotear, pois se por um lado o juiz representa o ideal de imparcialidade acima, por outro vivencia empiricamente as contradições de representar uma instância de poder e de pertencer, na maior parte das vezes, a uma classe social distante daquela a que pertencem os trabalhadores que apelam ao seu julgamento. Márcio Túlio Viana, juiz aposentado do TRT da $3^{\text {a }}$. Região e professor nas Faculdades de Direito da UFMG, afirma: "Por mais que o juiz, às vezes, pareça simpático à causa do trabalhador, quem se identifica com ele é o empregador: ambos falam a mesma língua, vestem-se de forma semelhante, têm a chave para decodificar os 
símbolos”. Admite ainda que toda a cena jurídica em que o trabalhador é inserido como coadjuvante, embora sendo o principal interessado, é discriminatória, e o próprio juiz, mesmo sem a intenção expressa, discrimina, o que fica evidente no contexto da cena genérica audiência:

O processo é algo muito mais intrincado e complexo do que um conjunto de regras formais, entre as quais o juiz se movimenta. Não é apenas um composto de prazos, recursos, sentenças, petições. É também o modo de falar, o jeito de ouvir, a forma de olhar; são as vestes talares, o estrado alto, o linguajar rebuscado, o argumento mais hábil. É tudo isso e muito mais: como as raízes de uma árvore, ele se irradia para além dos papéis, para além da lei e para fora da sala de audiências. Se o que não está nos autos não está no mundo, o que está no mundo está sempre nos $\operatorname{autos}^{4 . .}{ }^{45}$

A audiência trabalhista constitui-se assim como espaço discursivo privilegiado, na medida em que, mais do que na petição trabalhista, os elementos significativos das contradições que levam à discriminação estão presentes. Seu objetivo, enquanto gênero (que portanto possui função social), é ser o local discursivo em que as partes poderão, em presença, dirimir a questão a partir do que foi relatado em petição. Para cumprir seu objetivo, a petição dispõe de uma sintaxe enunciativo-discursiva externa ${ }^{46}$ (Di Fanti, 2004), responsável por organizar a audiência em partes, ou seqüências de desenvolvimento. Tal sintaxe busca tornar homogêneas as situações de conflito e, nesse sentido, é responsável pelos efeitos monofonizantes do gênero e por suas regularidades. Também segundo Di Fanti (2004), a audiência possui ainda uma sintaxe enunciativo-discursiva interna, que é constituída pelos enunciados propriamente ditos e que, embora sob coerção genérica, apresentam singularidades que constroem sentidos que escapam à tendência à monofonização do gênero. Observando-se a tensão entre as sintaxes, que se articulam, nasce uma compreensão mais profunda das relações que se estabelecem em audiência e de seus significados, que extrapolam a esfera jurídico-trabalhista, ao mesmo tempo que elucidam muitas de suas contradições.

\footnotetext{
45 Trechos da entrevista concedida pelo juiz Márcio Túlio Viana ao jornal Qualidade de Vida, do Centro de Estudos Avançados em Economia Aplicada da USP, ano 3, n. 27, agosto de 2001.

${ }^{46}$ Di Fanti descreve tal sintaxe como sendo a estrutura esquematizada do desenvolvimento da audiência, contendo as seguintes partes: 1. Acordo ou proposta para acordo (havendo acordo, há a emissão do Termo de Audência e encerra-se o litígio; não havendo acordo, prossegue-se a instrução processual); 2. Depoimentos: 2.1 Pessoais (seguidos de perguntas do juiz e dos advogados) e 2.2 Testemunhais (com advertência do juiz sobre a responsabilização penal em caso de falso testemunho, contradita a testemunhos e perguntas do juiz e advogados); 3. Emissão do Termo de Audiência (conclusão).
} 
A entrevista inicial trabalhador-advogado, enfim, como gênero não legal e introdutório ao processo, é o local em que a voz do trabalhador mais encontra espaço para sua expressão. Este gênero não apresenta uma versão escrita, constituindo-se como gênero oral e informal no processo trabalhista. Justamente por isso, é aberto e heterogêneo. Os três gêneros analisados em conjunto, como elementos de um único processo discursivo de manifestação da voz do trabalhador (tendo na petição seu eixo central), mostram o caminho de construção dessa voz, que se faz através de diferentes níveis de representatividade. O capítulo seguinte procurará abarcar e explicar esta construção. 
OS CAMINHOS DA CONSTRUÇÃO DO SENTIDO DA VOZ DO TRABALHADOR 


\section{OS CAMINHOS DA CONSTRUÇÃO DO SENTIDO DA VOZ DO TRABALHADOR}

Como já foi dito, entendemos representatividade discursiva como posições de sujeito construídas no discurso e que são determinadas no e pelos gêneros. Tais posições discursivas podem ser consideradas interdiscursos que constituem o discurso jurídico trabalhista e explicitam parte das idiossincrasias do mundo do trabalho.

Entendemos que as posições discursivas constroem-se mutuamente, estando na base de toda a pesquisa, portanto, a natureza dialógica da linguagem. É a categoria interdiscurso (Maingueneau 1984, 1997) que move a análise dos processos de transformação do nível de representatividade do sujeito trabalhador de um gênero a outro. Em outras palavras, os diferentes níveis de representatividade do sujeito trabalhador (posições discursivas distintas), determinados por coerções de gênero, são aqui considerados como interdiscursos. Considera-se ainda que certos gêneros caracterizam-se por ser primordialmente monofonizantes (ou pertencentes aos modos de generecidade 1 e 2 , de acordo com Maingueneau, 2004) como a petição, enquanto outros constroem-se com maior abertura à polifonia (ou pertencem aos modos de generecidade 3 e 4), como a entrevista. Devido à natureza dialógica da linguagem, no discurso jurídico trabalhista como um todo, a tensão entre efeitos monofonizantes e efeitos polifônicos é constante e apreensível lingüisticamente, possibilitando-nos entrever os interdiscursos e compreender o que está implícito.

Neste capítulo, nos itens 5.1 a 5.4, tratamos de averiguar como, com base nos textos em questão, a voz do trabalhador é construída nos gêneros entrevista inicial trabalhadoradvogado e petição trabalhista, o segundo decorrente do primeiro na prática discursiva em pauta. Nesse processo de construção, encontramos diferentes níveis de representatividade, expressos em um mesmo gênero e de um gênero a outro. Estamos diante, portanto, de um processo de construção que implica transformação da representatividade discursiva do sujeito trabalhador. Esta transformação traz implícitos interdiscursos do mundo do trabalho, aos quais cada nível de representatividade irá apontar. Um primeiro nível de transformação dessa representatividade é de caráter 
textual e é reconhecido através da análise dos processos de retextualização. Através desses processos, depreendem-se aspectos relevantes das cenografias dos gêneros analisados, cenografias tais que traduzem uma determinada imagem do sujeito trabalhador. Tais processos ocorrem sob a condução do locutor-advogado, a fim de produzir a petição trabalhista, documento escrito (portanto, legal) central no processo. Como já foi dito, só o que há de escrito nos gêneros do discurso trabalhista possui valor legal no direito do trabalho.

A análise dos processos de retextualização da entrevista inicial trabalhador-advogado para petição trabalhista remete às considerações de Bakhtin (1992) sobre estilo (seleção operada nos recursos da língua - recursos lexicais, fraseológicos e gramaticais) e construção composicional, cujo desenvolvimento em determinado texto corresponde ao que é de praxe no gênero em questão. Observar e compreender os processos de retextualização é em si compreender através de quais escolhas estilísticas e composicionais a voz do sujeito discursivo trabalhador está presente lingüisticamente nos textos e de que maneira tais escolhas, determinadas por coerção genérica, são a porta de entrada para os interdiscursos que constroem essa voz. Em outras palavras, de acordo com a terminologia de Maingueneau, compreender os processos de retextualização significa compreender as cenografias construídas nos respectivos gêneros e como tais cenografias se relacionam entre si.

A apreensão do sentido é ampliada ao avaliarmos o que para Bakhtin se chama conteúdo temático. Lembremos que, para o autor, um gênero se constitui como necessidade comunicativa numa esfera da atividade humana e que se materializa fundindo em sua elaboração os três aspectos: estilo, construção composicional e conteúdo temático. A análise do conteúdo temático neste trabalho corresponde, de maneira livre, à análise da cena englobante, pois entendemos que a compreensão de um "tema” implica compreender que um "tema” desenvolve-se sempre a partir de locais discursivos distintos e que tal desenvolvimento jamais é homogêneo e é sempre constitutivo do discurso analisado. Neste ponto, estaremos analisando um segundo nível de transformação dessa representatividade, o nível interdiscursivo ao qual se chega a partir do lingüístico (ou 
intradiscurso, como preferiria Courtine). Dito de outro modo, trata-se de, a partir das cenografias e de sua relação com os gêneros respectivos, compreender a cena englobante, em que mais claramente se observa a interdiscursividade constitutiva, e seu sentido mais amplo, que é a descrição da cena da enunciação.

Este segundo e mais profundo nível de transformação pode ser apreendido, assim, caminhando-se mais além na análise e buscando-se nos interdiscursos os fatores propulsores das mudanças. É neste nível que mobilizamos a categoria polifonia para a melhor apreensão lingüístico-discursiva da representatividade da voz do sujeito trabalhador nos gêneros em pauta e no discurso jurídico trabalhista de modo geral.

Por fim, averiguamos como se dá a constituição dessa voz especificamente na petição, analisando-se os processos de referenciação do eu-trabalhador que transfiguram o EU em OUTRO. Este OUTRO (locutor-advogado) passa a ser o sujeito da enunciação, assumindo a dianteira do processo de construção da direção argumentativa. Esta transformação é de caráter ao mesmo tempo lingüístico (cenográfico), marcado por coerção de gênero no nível do estilo e da construção composicional, e discursivo, marcado por determinações das cenas genérica e englobante.

Conforme explicitado no item 1.4 (Delimitação do objeto empírico), foram utilizados textos de processo trabalhista que acompanhamos na íntegra, escolhido por ser considerado típico pelos advogados que nos assessoram, e que ainda não foi finalizado, embora para efeito desta tese já o esteja. Observe-se que o processo trabalhista não termina com a audiência (a audiência de instrução e julgamento do processo em questão deu-se em 06/04/04). Ocorre que, a partir dela, não há mais manifestação da voz do trabalhador. A partir da audiência, o processo ocorre inteiramente dentro da instância do poder judiciário trabalhista. Observe-se ainda que os formulários que compõem o processo trabalhista passam a existir a partir da citação dos envolvidos e da intimação para comparecimento à audiência, e não antes. A grande parte irá simplesmente registrar as etapas do processo que se seguem à audiência, envolvendo procedimentos internos e obrigatórios, com referência indireta ao trabalhador. Tais formulários, enquanto gêneros, 
já foram devidamente comentados e serão novamente abordados nas considerações finais. A audiência será estudada no item 5.5.

Em síntese, o que a análise que se fará pretende mostrar é que a representatividade discursiva apreendida nos textos selecionados determina os sentidos da voz do trabalhador no discurso jurídico trabalhista.

5.1 Da entrevista à petição: processos de retextualização e distribuição das vozes discursivas

Como vimos em capítulo teórico, podemos entender retextualização, num primeiro momento, como o conjunto de operações pelas quais passa um determinado texto oral ao ser transformado em texto escrito. É importante frisar que não se trata de processo mecânico ou natural, mas de "processo que envolve operações complexas que interferem tanto no código como no sentido e evidenciam uma série de aspectos nem sempre bem compreendidos da relação oralidade-escrita” (Marcuschi, 2001). Tais aspectos nem sempre bem compreendidos estão ligados à falsa idéia de que a passagem do oral para o escrito equivale à passagem do caos à ordem. Esta relação não condiz com a realidade, uma vez que o texto oral não é caótico. É, isto sim, organizado de uma maneira que só recentemente os lingüistas e pesquisadores da área começam a compreender e descrever.

A organização textual de entrevistas orais é mais evidente, uma vez que o planejamento é explícito e existe um locutor (que é também um interlocutor empírico) que dirige o fio do texto para uma certa direção argumentativa. No entanto, a mesma organização existe nas conversações mais corriqueiras, aparentemente totalmente espontâneas e sem fio condutor. Ocorre que nestas últimas há maior afrouxamento das coerções que impelem à organização textual. Pode-se dizer que o que varia é o grau de coercibilidade do texto oral em função do gênero discursivo a que se subscreve.

Voltando à questão da retextualização, reforçamos que o processo implica necessariamente transformação, reformulação, modificação e mesmo recriação, daí não 
ser a retextualização equivalente à transcrição ou transcodificação. A retextualização implica, antes de tudo, compreensão. É preciso haver uma compreensão mínima do texto oral para que a partir dele se construa um texto escrito.

Uma primeira característica da entrevista inicial trabalhador-advogado, como texto de origem da petição, é justamente o fato de tal compreensão inicial e necessária ser bastante pequena, uma vez que o saber do advogado sobre o direito do trabalho e as causas trabalhistas mais comuns e seus conhecimentos específicos sobre o gênero petição cobrirem boa parte do conhecimento necessário à redação da petição. Essa compreensão abarca basicamente a apreensão de dados contextuais elementares sobre o trabalhador que o insiram em um quadro que torne seu caso específico. Tais dados são: data de entrada e saída do emprego, número de horas trabalhadas por dia, períodos em que gozou (ou não) férias e demais benefícios, número de horas-extras trabalhadas, recebimento de $13^{\circ}$. salário, etc. São também dados a serem apreendidos através dessa compreensão básica as informações pessoais mínimas, como nome completo, endereço, telefone, número dos documentos; e institucionais, como nome completo e CNPJ do empregador.

Simultaneamente à compreensão mínima (operação primordialmente de ordem cognitiva), realizam-se no processo de retextualização operações de caráter lingüísticodiscursivo (que é o que nos interessa nesta análise), que podem ser agrupadas, conforme Marcuschi, em três subconjuntos: idealização, reformulação e adaptação. As transformações ocorridas em função da idealização e da reformulação são as que atuam diretamente no código lingüístico (o que naturalmente afetará o discurso). A adaptação refere-se aos processos utilizados para tratamento dos turnos conversacionais, que na petição deixam de existir. Vale frisar que nenhum desses processos ocorre de forma mecânica ou ingênua, e que a transformação das falas da entrevista em conteúdos da petição acarreta profundas transformações ao nível do sentido. A análise da petição a seguir tratará de mostrar no texto retextualizado em pauta os aspectos principais de tais processos no gênero petição trabalhista e seus efeitos de sentido. 
Embora tais processos não sejam mecânicos, existem regularidades que os norteiam, como apontam os processos acima referidos. Além deles, toda a retextualização, inclusive a retextualização da entrevista oral à petição, está submetida a certas variáveis intervenientes (Marcuschi: 2001), que são: propósito ou objetivo; relação entre o produtor do texto original e o transformador; relação tipológica entre o gênero textual original e o gênero da retextualização; e os processos de formulação típicos de cada gênero.

Passemos a identificar no exemplo coletado (entrevista e petição inicial de determinado processo trabalhista) como se processam tais variáveis no processo de retextualização em foco:

Propósito: o objetivo da retextualização é evidentemente formalizar a reclamação trabalhista, enquadrando-a de acordo com as normas ditadas pelo gênero "petição trabalhista”, que por sua vez sofre as coerções próprias ao discurso jurídico trabalhista. Esta adequação ao novo gênero objetiva da mesma maneira atingir um certo leitor (o juiz trabalhista), que, igualmente por coerções de gênero e discurso, tomará conhecimento oficial desta reclamação apenas e unicamente através da petição trabalhista.

A adequação ao novo gênero exigirá o uso de uma linguagem formal, cuja gramática (entendida aqui como a competência discursiva que dita o conjunto de normas coercitivas do discurso jurídico trabalhista e que opera a seleção das formas gramaticais de acordo com tais coerções) apresenta alto índice de cristalização, desde uma sintaxe própria até o uso de formas lexicais (como jargões e expressões do meio jurídico trabalhista) altamente cristalizadas e próprias ao discurso em questão. O uso da anáfora, via escolha de expressões referenciais bastante específicas, é um exemplo de gramaticalização comum no gênero petição trabalhista. Aprofundaremos este ponto durante a análise da petição (item 5.4).

Relação entre o produtor do texto original e o transformador: é bastante interessante notar como nossa análise, neste ponto específico, contraria a posição teórica de Marcuschi sobre tal aspecto, pois a perspectiva deste trabalho é eminentemente 
discursiva. Para Marcuschi, nos casos em que o autor do texto em processo de retextualização diverge do autor do texto oral, há maior “respeito” pela fala original, o que implica maior dificuldade para apagar as marcas da oralidade no texto escrito final. Ocorre que, no caso da retextualização da entrevista inicial à petição, este “respeito” à fala original inexiste. Isto ocorre devido à forte institucionalização do gênero petição trabalhista, que se desenvolve a partir da apropriação da voz do sujeito trabalhador pelo locutor-advogado.

O gênero petição opera argumentativamente muitas vezes de forma completamente diversa da imaginada pelo requerente, simplesmente porque este último não possui o conhecimento prévio especializado. Neste ponto, a competência discursiva ditará uma nova orientação, que se caracterizará no texto final como a direção argumentativa construída pelo locutor-advogado.

Relação tipológica entre o gênero textual original e o gênero da retextualização: embora a mudança seja abrupta entre um gênero e outro, a tipologia textual no segundo texto guarda semelhanças com a tipologia do primeiro. De fato, nos dois casos o texto se constrói sobre a narração e a argumentação, segundo tipologia de Adam (2002). Por um lado temos os fatos "narrados” pelo reclamante (no texto oral) e pelo locutor-advogado (no texto escrito), e por outro temos a argumentação construída pelo reclamante (no texto oral) e pelo locutor-advogado (no texto escrito). Claro está que a argumentação construída no texto oral pelo reclamante é "pobre" se comparada à desenvolvida pelo locutor-advogado no texto escrito, tendo-se em mente a competência discursiva que constrói o gênero petição. O sujeito autor da causa argumenta em geral com base na intuição de que foi lesado, pois se sente de algum modo injustiçado. Sua fala pode dar-se de modo disperso, cabendo ao locutor-advogado "reconstruir" os fatos. Pode ocorrer que fatos narrados como eventuais ou fortuitos sejam conectados pelo locutor-advogado, a fim de construir o fio condutor necessário. O locutor-advogado, assim, argumenta principalmente com base em um saber discursivo especializado. Para este último, a importância relativa dos fatos narrados pelo trabalhador se alia à sua competência discursiva específica, sustentada pelo conhecimento da legislação trabalhista. 
Processos de formulação: neste aspecto, o texto da retextualização, por pertencer a um gênero muito estável, submete-se completamente às características do gênero alvo, deixando pouquíssimas marcas do texto original. Os processos de formulação do texto final imbuem-se justamente desta função central: a de neutralizar as marcas do texto oral original. Podemos arriscar dizer que, na petição trabalhista, esta neutralização atinge o ponto alto, de tal modo que apenas uma análise discursiva, que vá além do textual, pode desfazer o apagamento e expor os elementos lingüístico-discursivos originais para que haja uma compreensão sócio-histórica do fenômeno. Neste ponto, fazemo-nos valer fortemente do conceito de interdiscursividade de Maingueneau, que pressupõe a constituição conjunta de EU e OUTRO. É este pressuposto que assegura a interpretação das marcas lingüísticas da petição, de modo a recuperar-se, através desta intertextualidade pouco explícita, mas detectável, o interdiscurso.

Observe-se ainda que o texto falado original orienta-se para o passado, na medida em que seu enunciador recolhe retrospectivamente os fatos que compõem sua história para expôlos ao advogado. Esta retrospectiva é aleatória, como se vê na transcrição da entrevista que gravamos para esta análise, cabendo ao advogado organizar temporalmente os fatos. Por outro lado, o texto retextualizado, ou seja, a petição, orienta-se para o futuro, pois, como gênero institucionalizado dentro do espaço discursivo da justiça do trabalho, possui objetivos a concretizar que se projetam adiante no tempo. Tais efeitos discursivos em si indicam uma mudança importantíssima do texto original ao texto retextualizado e delimitam os respectivos gêneros e seus objetivos sociais. O tempo linear, ou cronológico, por sua vez, traz em si as possibilidades de apreensão do tempo processual do discurso, que o atravessa e se caracteriza pelo interdiscurso, que agrupa de forma complexa em um mesmo tempo (o tempo da enunciação) os domínios da memória, da atualidade e da antecipação.

Baseando-nos em Alves (1992), que realizou estudo similar, de uma maneira geral notase na petição: 
- Apagamento sistemático das perguntas do locutor-advogado, o que gera a construção de um texto que tende ao monológico.

- Substituição sistemática de terminologia coloquial por terminologia própria ao gênero (uso de jargões e expressões típicas do discurso jurídico).

- Reordenação tópica, com uso de conectores e demais recursos coesivos próprios a gêneros formais. Tal reordenação constrói a cenografia específica daquele texto, respeitadas as coerções genéricas.

- Transformações interpretativas com supressão de informações.

- Omissões, quando a presença de fatos narrados originalmente comprometem a argumentação da petição.

- Inserção de informações, quando consideradas relevantes para dar corpo à direção argumentativa.

- Verbalização dos contextos com identificação clara dos referentes.

Procuraremos apontar também na análise da petição a seguir, comparando-a à entrevista inicial, como tais características se apresentam no texto escrito final. Para tanto, iremos nos utilizar, por um lado, da primeira gravação realizada para compor a parte oral do corpus (e que se constitui fundamentalmente das falas do trabalhador e seu advogado em seu primeiro encontro); e por outro da petição inicial para pedido de horas-extras, gênero que se constrói a partir da entrevista. Os textos na íntegra estão nos Anexos.

\subsubsection{Análise da entrevista}

Como é próprio ao gênero "entrevista”, a entrevista inicial entre advogado e trabalhador não é uma conversação em sentido estrito. Conforme Marcuschi (1991), que segue a proposta de Dittmann (1979: 5-6), tal conversação é um diálogo assimétrico, em que, ao contrário das conversações do dia-a-dia, "um dos participantes tem o direito de iniciar, orientar, dirigir e concluir a interação e exercer pressão sobre o(s) outro(s) participante(s)” (Marcuschi, 1991:16). 
A pressão que o locutor-advogado exerce não vai, em princípio, de encontro aos interesses de seu interlocutor, uma vez que o locutor-advogado lá está para posicionar-se ao lado do sujeito trabalhador. No entanto, baseado em seu conhecimento prévio sobre a justiça do trabalho - conhecimento este não partilhado com o trabalhador -, o advogado irá, necessariamente, mais do que dirigir o diálogo, definir toda a sua orientação argumentativa desde o início. Como o objetivo central da entrevista, enquanto gênero que tem função social no embate comunicativo, é levantar a informação necessária para a elaboração da petição inicial ao juiz, o advogado posiciona-se no diálogo com o objetivo de se apropriar da fala do trabalhador a fim de torná-la boa argumentação (no sentido retórico) no texto escrito a ser elaborado, nem que para isto a fala do trabalhador tenha de ser explicitamente modificada ou suprimida. Tem-se aqui a clara figura do locutororquestrador discursivo.

Observe-se o seguinte trecho (ver transcrição completa no Anexo A, onde os trechos pontualmente analisados estão em negrito), em que L1 é o locutor-advogado e L2 é o sujeito trabalhador:

“L1 Alguma dessas testemunhas, você passava o cargo pra eles?

L2 Às vezes sim, porque, sabe, a gente tinha um rodízio, né?

L1 Então passou a passar sempre, tá?

L2 Hã?

L1 Passou a passar sempre.

L2 Ah!...tá. Ha! Há!”

Para surpresa do trabalhador, o advogado assume a dianteira em relação ao fato, recriando-o com o objetivo de torná-lo melhor argumento (no sentido retórico) perante a justiça do trabalho. "Passar o cargo ao mesmo colega todos os dias" significa dar substância ao argumento.

É interessante notar que o trabalhador percebe a necessidade de adaptação da sua fala, mas não imediatamente. E ri da própria ingenuidade, ou falta de conhecimento prévio do 
meio jurídico em que está entrando. Por outro lado, note-se que o advogado não explicita a ação que pretende empreender, mas deixa-a implícita, o que nos faz apreender uma certa precaução por parte do advogado: certas coisas precisam ser feitas, mas é bom que não sejam ditas, ou apenas ditas parcialmente. Conforme Coulthard (1977), apud Marcuschi (1991:77), “sabemos que algumas coisas são conversáveis e outras não”. O dizer desmascara um procedimento que fere o princípio da verdade, caro no meio jurídico, embora na prática seja a construção de um sentido de verdade que vai conduzir os processos.

A assimetria da conversação permite ao locutor-advogado apropriar-se da palavra a qualquer momento, desde que considere a tomada de turno relevante para a boa construção do sentido de verdade que se materializará no texto da petição. Observe-se outro trecho extraído da transcrição (ver transcrição completa no Anexo A):

L1 Quando é que você foi pra Vila Mariana...((hesitação)) ... você:: ... quando contratado... já foi pra Vila Mariana?

L2 Não ... eu era da:: ... eu fui ( Moema, trabalhei aqui na Ibirapuera, no (posto) do Ibirapuera...

L1 Quanto tempo mais ou menos?

L2 ((hesitação)) uhn:: ... só até noventa e seis ...

L1 ( ) Moema?

L2 É::...

((vozes simultâneas))

L1 Aí de Moema você foi pra Vila Mariana... 
L2 Daí eu fui pro Detran...

L1 Não... pra Vila Mariana...

L2 É:: ... agência Vila Mariana do posto do Detran.

L1 Ok... Aí você ficou no posto e aí depois você voltou pra agência...

L2 É... não... eu não cheguei a ir pra agência... eu fui direto... né? eu fui ... ((hesitação)) da agência de Moema...

L1 É que você falou pra mim que nos últimos cinco anos você tinha trabalhado em dois lugares...

L2 Isso... quatro no Detran e um na Vila... Detran é um posto da Vila Mariana...

L1 Tá...

L2 Um posto da Vila Mariana...

L1 Você trabalhou um ano lá...

L2 Na agência sim... e quatro lá no posto... lá no Detran...

É problema nos estudos de análise da conversação a definição clara do que seja lugar relevante para a tomada de turno. De um ponto de vista discursivo, que é o nosso, neste tipo de entrevista a tomada de turno dá-se preponderantemente pelo locutor-advogado por coerção de gênero e, ao que pudemos observar, sem necessidade de haver qualquer deixa para tal, desde que, é claro, isto seja coerente com a direção argumentativa definida pelo locutor. Não há o que na análise da conversação se chamam tomadas de turno que se constituam como assaltos ou usurpação da palavra do outro, uma vez que, como já dito, o advogado posiciona-se ao lado do trabalhador e este cede sua palavra ao seu interlocutor. 
As tomadas de turno são pacíficas. Ocorre que, mais do que fruto de uma decisão tomada entre interlocutores, as tomadas de turno "pacíficas" são fruto de necessidades que se impõem ao nível da própria constituição dos gêneros do discurso jurídico trabalhista, que têm na vocação para a paz social o seu eixo (como já foi visto). Assim, as vozes que irão constituir o texto da petição, e que coincidem com as vozes do advogado e do trabalhador construídas na entrevista, tendem a caminhar para a homogeneidade discursiva. Claro está, uma homogeneidade construída, que, por certas marcas lingüísticas que desnudam a polifonia, é possível contestar.

As hesitações, próprias a qualquer tipo de conversação, servem em geral “como momentos de organização e planejamento interno do turno e dão tempo ao falante de se preparar” (Marcuschi, 1991:27). No caso deste tipo de entrevista, as hesitações parecem ocorrer mais acentuadamente nos turnos do sujeito trabalhador, que precisa constantemente organizar sua fala de acordo com a direção argumentativa imposta pelo advogado. De um ponto de vista discursivo, as hesitações podem ser vistas como marcas polifônicas que apontam para interdiscursos que atestam um certo tipo de representatividade do sujeito trabalhador.

Como em qualquer conversação, neste tipo de entrevista, o tópico é desenvolvido pelos sujeitos durante a seqüência dos turnos de forma linear (temporal) e sem possibilidade de reversão. Nesse tempo linear em que se dá a entrevista não se pode programar o seguimento completo. No entanto, por se tratar de gênero conversacional fortemente institucionalizado, com marcada assimetria na relação entre os sujeitos, é possível prever o que se deseja ao término da entrevista. Esta previsão é feita pelo locutor-advogado, que sabe exatamente que informação recolher ou que tipo de argumento elaborar para tornar coerente o texto escrito a ser produzido a partir desta primeira interação oral.

A organização do tópico, assim como a própria noção de coerência do texto oral produzido na entrevista, está diretamente relacionada às condições impostas pelo modelo institucionalizado: petição trabalhista. 
Embora ambos os interlocutores saibam de antemão que o tópico geral de sua conversação é a coleta de informações que servirão de base para convencer o juiz a respeito do mérito de um direito que, em tese, não foi respeitado, é apenas o locutoradvogado que possui a noção global do tópico e seus desdobramentos, e o sujeito que possui os meios para formalizar a fala do OUTRO, do sujeito trabalhador. Mesmo tomando sistematicamente a dianteira durante a entrevista, esta, embora assimétrica, não deixa de constituir-se antes de tudo como uma interação, em que a fala é construída pelos dois interlocutores, ambos sujeitos de uma co-produção discursiva e comandados de alguma forma pela fala um do outro. Assim, o locutor-advogado também modela seu discurso pela fala do trabalhador, pelo que nela há além do puramente informativo.

\subsubsection{Análise da petição do ponto de vista dos processos de retextualização}

Ao confrontarmos a petição de pedido de hora-extra (ver reprodução no ANEXO B) com o texto da entrevista inicial, podemos evidenciar as estratégias de retextualização na passagem de um gênero a outro:

1) Supressão do esquema perguntas $x$ respostas e das marcas da oralidade: a petição é construída com base, em um primeiro momento, no apagamento das perguntas feitas pelo locutor-advogado, que são substituídas pelas justificativas e por argumentação com base em citações da lei ${ }^{47}$. A petição constrói-se assim como texto com efeito monológico. Importa frisar que isto não significa o apagamento da dialogicidade própria a qualquer texto. O apagamento do esquema pergunta $\mathrm{x}$ resposta constitui-se como uma das estratégias de construção de um sentido mais homogêneo, mais canalizado para uma certa direção argumentativa. O próprio uso desta estratégia, de acordo com uma visão lingüístico-discursiva global, atesta a polifonia e conseqüente interdiscursividade.

\footnotetext{
${ }^{47}$ As citações são marcas lingüísticas que atestam a polifonia. Neste caso, no entanto, por remeterem a interdiscursos do próprio discurso jurídico trabalhista, inserem-se na cenografia para reforçar o efeito monofonizante do gênero petição.
} 
Apagam-se também as respostas dadas pelo trabalhador, que são recriadas no corpo da petição como justificativas. Toda a fala do trabalhador é transfigurada na fala do OUTRO que se constitui como EU na petição, ou seja, na fala do locutor-advogado, que se apropria do texto e o transforma de acordo com o seu conhecimento prévio especializado e com a direção argumentativa por construir.

Toda marca de oralidade (para nós marcas de interdiscursividade), dos marcadores conversacionais às hesitações, tendem ao apagamento. As frases curtas e encadeadas sem preocupação com coordenação ou subordinação são substituídas por parágrafos redigidos conforme o padrão da norma culta escrita e de acordo com a norma jurídica para redação de textos.

As marcas da oralidade observáveis ao compararmos os gêneros remetem ao interdiscurso do mundo do trabalho, em que o trabalhador aparece como sujeito com especialidade alheia às questões do Direito e como sujeito do que poderíamos chamar de "mundo da vida”, em que o trabalhador aparece antes de tudo como homem comum que trabalha para seu sustento para cumprir seus papéis sociais dentro e fora da família.

2) Adequação da terminologia: evidentemente, toda a terminologia coloquial é suprimida. Pela voz do locutor-advogado ecoam os jargões e expressões próprias ao discurso jurídico, o que também nos remete à questão da interdiscursividade, pois o jargão jurídico marca a distinção entre dois mundos: do Direito e do trabalho, que se interconstituem no discurso jurídico trabalhista.

A voz do trabalhador é recuperada, principalmente, através da análise dos processos de referenciação ao trabalhador construídos pelo locutor-advogado de acordo com sua competência discursiva.

3) Reordenação tópica: não há propriamente uma reordenação tópica, mas sim a construção de uma nova seqüência tópica, própria ao gênero. Conforme se dirá na análise desenvolvida no item 5.4, o texto ora analisado apresenta o parágrafo introdutório de 
praxe que contextualiza a causa, precedido de saudação ao juiz, e seguido da justificativa e argumentação.

No caso desta petição, há antes da justificativa e da argumentação a solicitação dos benefícios da justiça gratuita, pedido justificado com base em lei. Esta solicitação foi sugerida pelo próprio advogado na entrevista inicial, sendo aparentemente uma prática comum e que, como veremos, ajuda a construir a direção argumentativa.

Na justificativa, onde são relacionados os fatos que dão base ao pedido de pagamento de horas-extras, encontra-se a fala do trabalhador retextualizada. São sete parágrafos de texto, incluindo-se a citação de trecho do termo de rescisão contratual (estão em negrito na versão original no Anexo B), construídos especificamente a partir da fala do trabalhador na entrevista inicial. Observe-se que, se comparado ao texto correspondente na petição, o texto da transcrição da fala do trabalhador ocupou mais espaço em número de parágrafos e páginas, o que significa que a retextualização, neste caso, realiza um tipo de síntese do texto original. Trata-se de uma síntese bastante específica, pois, além dos cortes e omissões, há acréscimos.

Como já ficou claro, os cortes e omissões são feitos obedecendo-se a uma dupla exigência:

- a de adaptação de um gênero a outro, com todas as implicações discursivas que esta transposição traz em seu bojo;

- e a de adaptação de um registro mais informal, distenso, para outro, formal e tenso.

Os acréscimos, além de obedecerem às mesmas exigências, caracterizam-se por não estarem explícitos na fala original do trabalhador, mas sim em documentação por ele trazida ou levantada pelo advogado, e por este último interpretada e expressa no texto final em função das coerções genéricas. 
Observem-se os seguintes trechos da petição, comparando-os aos respectivos textos da entrevista. Atenção especial à rerefação de conteúdo do texto oral, o que implica, na prática da produção discursiva, quantidade muito maior de texto.

Na petição:

“O reclamante cadastrado sob o código de empregado número 6931810847701 foi admitido aos serviços do Banco-reclamado em data 23 de Maio de 1.988 e demitido sem justa causa em 20 de Setembro de 2.001.”

Na entrevista:

L1 Quando é que você foi pra Vila Mariana...((hesitação)) ... você:: ... quando contratado... já foi pra Vila Mariana?

L2 Não ... eu era da:: ... eu fui ( ) Moema, trabalhei aqui na Ibirapuera, no (posto) do Ibirapuera...

L1 Quanto tempo mais ou menos?

L2 ((hesitação)) uhn:: ... só até noventa e seis ...

L1 ( ) Moema?

L2 É::....

((vozes simultâneas))

L1 Aí de Moema você foi pra Vila Mariana...

L2 Daí eu fui pro Detran... 
L1 Não... pra Vila Mariana...

L2 É:: ... agência Vila Mariana do posto do Detran.

L1 Ok... Aí você ficou no posto e aí depois você voltou pra agência...

L2 É... não... eu não cheguei a ir pra agência... eu fui direto... né? eu fui ... ((hesitação)) da agência de Moema...

L1 É que você falou pra mim que nos últimos cinco anos você tinha trabalhado em dois lugares...

L2 Isso... quatro no Detran e um na Vila... Detran é um posto da Vila Mariana...

L1 Tá...

L2 Um posto da Vila Mariana...

L1 Você trabalhou um ano lá...

L2 Na agência sim... e quatro lá no posto... lá no Detran...

L1 Que ano que foi isso aí... na agência?

L2 Foi no último ano... foi dois mil e um... né?

L4 Dois mil e um ...

L1 Na agência?

L2 Foi no último ano...

L1 E os quatro anos anteriores no Detran? 
L2 Isso...

Na petição:

"No exercício da função de Caixa, subordinava-se à jornada contratual de 6 (seis) horas diárias, com início às $07 \mathrm{~h} 00$ e término às 13h00, isto de Segunda às Sextas-feiras, usufruindo de intervalo para descanso de 15 minutos.

Fato é que a reclamante iniciava seu expediente em média às 06h00 e encerrava-o às 14h00.” 
Na entrevista:

L2 Óh... no Detran tinha:: ... a gente teve vários horários ... eu:: ... eu quando entrei no Detran trabalhava na área de ( ) ... então eu entrava ... entrava tipo duas da tarde mas tinha dia que eu saída onze horas... meia-noite... tinha dia que eu saía às oito... não tinha um horário fixo...

L1 Mas o teu horário CONTRATUAL ... que horário era... o contratual? era das dez às dezesseis?

L2 Nesses últimos quatro anos?

L1 É...

L2 Não... tinha vários... tinha das seis até meio-dia... que eu entrava no Detran... tinha das sete até a::: ...até a uma...

L1 Eu preciso que você me detalhe isso... eu preciso que você me detalhe isso... ( )

L2 Ah... tá... acho que eu não sei se eu vou conseguir falar assim porque não tinha::... era registro de agência... por exemplo... a gente assinava o ponto...

L1 Mas veja bem... o Banespa vai mostrar lá pro juiz o ponto assinado por você...

L2 Sim...

L1 E esse ponto é cheio... o que é ponto cheio? você entrava às sete horas e saía treze horas...

L2 É... é isso que eu tava falando pro (...) 
L1 Você nunca vai entrar sete e um... sete e dois... você vai entrar sempre sete horas e sair treze horas...

L2 É mas aí a gente assinava ... eles mandavam a gente assinar tipo::... é::...sei lá::...

L1 Um... dois... três... quatro... cinco... seis... fazer uma:....

L2 É... não... fazia assim... coloca:: ....

L1 Sim... mas isso agora...

L2 Seis e quinze...

L1 Não... mas de um ano e meio pra cá...

((estas últimas quatro falas quase simultaneamente))

L2 Isso...

L1 Mas antes não... antes era cheio...

L2 Hã hã... é::....

L1 e L2 Antes era cheio... ((simultaneamente))

L2 É...

L1 Então veja bem... eu não posso falar do horário de trabalho sem isso daqui ( Eu tenho que dizer que aquele seu horário de trabalho::... só vou concordar com o horário de entrada... ( ) o horário de saída eu protesto. Só com o horário de entrada ( ) eu não posso ( ) no empírico... nós precisamos colocar a realidade dos fatos... 
L2 É::...

L1 Eu preciso que você... você assine aí qual o período que você entrava... de tanto a tanto eu entrei no horário tal e saí no horário tal... contratual... não quero saber o horário verdadeiro que você saiu... não interessa...

L2 Certo... por que (...)

L1 Certo?

( )

L2 Bom... na agência::... era o horário normal de agência... né?

( )

L1 Na agência você trabalhou de quando a quando?

L2 Setembro:.... foi de setembro ... não lembro se é outubro de dois mil... até setembro de dois mil e um... alguma coisa tipo assim...

L1 Na agência Vila Mariana?

((L2 assente com a cabeça))

L1 Outubro ou setembro... vamos trabalhar com (setembro)... setembro de dois mil a setembro de dois mil e um... e você trabalhou na agência da Vila Mariana... ok?

L2 É::... de um ano... né? ((simultânea desde a metade da fala anterior))

L2 Isso... 
L1 E na agência Vila Mariana era horário contratual?

L2 Isso... lá era horário contratual...

L1 ( )

L2 Isso...

L1 Aí teve aquele...

L2 O horário anterior era das nove...

L1 Entrava nove e trinta...

L2 Isso...

((L2 confirma rapidamente com L4 o horário))

L1 Então você teve o horário das nove às quinze... você teve o horário das dez... mas você lembra de ter tido às nove e trinta ...?

L2 Uhn... não... quebrado não...

L1 Só os dois... O horário era das nove... das nove às quinze e das dez às dezesseis... é isso?

L2 Isso...

L1 Bem fácil... 
L2 No Detran tive horário...

L1 Na agência... na agência... vamos ficar na agência... que é esse último ano...

L2 Certo...

L1 Como é que é lá:: ... você marcava o horário... esse horário ( .... marcava sempre dezesseis horas?

L2 É:: ... lá sempre é assim.... não... não... lá era aquele horário picadinho... eles marca quinze... marca dez... cinco pras (...) ... eles sempre davam quinze minutos... entendeu? eles falavam assim... então marca dez pras dez e a saída:: ... ((hesitação)) dezesseis e cinco... eles ficavam ... ( ) esses 15 minutos...

L1 Marca um... marca dois... dezesseis e um... dezesseis e dois ... bom... de setembro... então... de agosto de dois mil e um ... agosto dois mil... agosto de noventa e nove... agosto noventa e oito... você estava no Detran...

4) Transformações interpretativas: observando os trechos extraídos acima, conclui-se que a petição é um gênero que se constrói a partir de fortes transformações interpretativas, com supressão e/ou acréscimo de informações. Tal fato não descaracteriza a petição como gênero retextualizado a partir da entrevista inicial, como se poderia pensar em princípio, mas, pelo contrário, mostra com clareza o grau de amplitude que os processos de retextualização podem atingir quando se tem em vista as condições de produção do discurso e as práticas institucionalizadas de uso dos gêneros. Do ponto de vista do acréscimo de informação, a voz do trabalhador funciona como ponto de partida para uma pesquisa detalhada que será feita nos documentos trabalhistas do referido empregado. Do ponto de vista da supressão de informação, a voz do trabalhador funciona como uma espécie de termômetro do que não deve ser dito. Desta forma, quando o locutor-advogado ouve seu trabalhador, além de informação, ele quer apreender o que, no dito, não pode ser dito. 
Como dissemos, a análise dos processos de retextualização nos remete a um primeiro nível de transformação, sendo insuficiente para a máxima apreensão dos sentidos construídos. Observe-se um outro exemplo para o qual a análise da retextualização é evidentemente insuficiente. Veja-se que a leitura inicial dos trechos a seguir não é sequer suficiente para que se perceba que o primeiro é decorrente do segundo. Mesmo considerando-se retextualização de modo bastante amplo, só a análise dos interdiscursos contemplará a construção do sentido de forma satisfatória.

Na petição:

“No exercício da função de Caixa, subordinava-se à jornada contratual de 6 (seis) horas diárias, com início às 07 h00 e término às 13h00, isto de Segunda às Sextas-feiras, usufruindo de intervalo para descanso de 15 minutos.

Fato é que o reclamante iniciava seu expediente em média às 06h00 e encerrava-o às 14h00. Todavia, por exigência do Banco-reclamado, lhe era obrigado a assinalar em folha de freqüência o horário contratual, jamais a efetiva jornada laboral prestada além daquele horário, conforme demonstrará provado em instrução processual." (grifos meus)

Na entrevista:

\section{L1: Alguma dessas testemunhas, você passava o cargo pra eles?}

L2: Às vezes sim, porque, sabe, a gente tinha um rodízio, né?

L1: Então passou a passar sempre, tá?

L2: Hã?

L1: Passou a passar sempre.

L2: Ah!...tá. Ha! Há!

(grifos meus) 
Interessa-nos em especial o trecho da petição que começa em "todavia...” e se estende até o final do parágrafo (trecho em negrito), cuja produção é decorrência do combinado na entrevista inicial (trecho em negrito). As instruções processuais ao juiz fazem referência às testemunhas. O argumento só se tornará efetivo perante o juiz se as testemunhas arroladas confirmarem que assumiam o cargo após a saída do trabalhador (às 14h) e, em conseqüência, viam o trabalhador-reclamante realizar a hora-extra. Esta relação, por estar implicitada, só pode ser mais amplamente compreendida se recorrermos a outras categorias, como veremos adiante, no item 5.3.

\subsubsection{A voz do trabalhador ganha corpo}

Os esforços discursivos para a construção dos dois gêneros, que se materializam em enunciados (textos), representam os esforços para a construção da materialidade lingüística da voz do sujeito discursivo trabalhador no discurso jurídico trabalhista. Claro está que a materialização se faz a partir dos interdiscursos que constituem o discurso jurídico trabalhista e que nos levarão a sentidos mais amplos, mas neste ponto importa ressaltar que nesses esforços a voz do sujeito trabalhador ganha corpo. Sobressai-se ou se apaga em função de diferentes fatores discursivos, mas está inegavelmente presente, e de modo institucional e legal na petição trabalhista.

A voz do trabalhador no discurso jurídico trabalhista é sujeita a diferentes estratégias de apagamento e explicitação nos diferentes gêneros que materializam tal discurso. Da tensão criada entre as estratégias de apagamento e de explicitação da voz do trabalhador no discurso em pauta, apreende-se a polifonia. A polifonia, por sua vez, faz entrever interdiscursos que caracterizam a voz do trabalhador de formas diferentes nos dois gêneros ora estudados.

5.2 Gênero entrevista: o sujeito discursivo trabalhador ganha voz

\subsubsection{Efeito polifônico}


A entrevista trabalhador-advogado, embora não sendo gênero discursivo legal, é considerado gênero oficial no discurso jurídico trabalhista porque sua existência é prérequisito consensual para a redação da petição, o documento legal que formalizará a queixa trabalhista ao juiz e no qual o juiz se baseará para conduzir a audiência e emitir seu julgamento.

A entrevista trabalhador-advogado, como toda entrevista, caracteriza-se pela assimetria entre os locutores discursivos. O sentido é construído em conjunto, mas apenas o locutor orquestrador, com aval de seu co-enunciador, é responsável pela condução geral dessa construção. No caso da entrevista trabalhador-advogado, cabe à figura discursiva do advogado conduzir a construção de sentido. É a figura do advogado que detém o conhecimento jurídico, especializado, constituindo-se assim como figura autorizada a atuar na condução geral da entrevista.

A assimetria entre os locutores já é em si marca polifônica. Mas a polifonia que nos interessa em especial nesta análise, e que nos conduzirá a interdiscursos e a sentidos implícitos, é mais sutil.

Passemos ao aprofundamento da análise do pequeno trecho abaixo, já visto anteriormente, extraído da entrevista original (versão na íntegra no Anexo A), tendo-se em vista que: $\mathrm{L} 1$ = figura discursiva do advogado e L2 = figura discursiva do trabalhador.

L1: Alguma dessas testemunhas, você passava o cargo pra eles?

L2: Às vezes sim, porque, sabe, a gente tinha um rodízio, né?

L1: Então passou a passar sempre, tá?

L2: Hã?

L1: Passou a passar sempre.

L2: Ah!...tá. Ha! Há! 
Antes de mais nada, é preciso contextualizar o trecho para que faça sentido. L2 (o sujeito trabalhador) quer requerer ao juiz do trabalho, através de abertura de processo trabalhista, o pagamento de horas-extras realizadas como caixa em determinado Banco. O trabalhador alega que foi despedido sem o pagamento pelo total de horas efetivamente trabalhadas durante o exercício de sua função de caixa. Para tal, em entrevista inicial com o advogado (normalmente todo processo trabalhista é conduzido por um advogado que orienta e concretiza o pedido ao juiz), o trabalhador deve esclarecer exatamente os horários em que trabalhou e provar ter feito as horas-extras. No trecho em pauta, o advogado quer que seu trabalhador compreenda a importância de alegar que passava o cargo todos os dias, em horário posterior ao seu horário de saída normal, exclusivamente para as pessoas arroladas como testemunhas no processo. Isto porque não se deve correr o risco de haver alguma contradição na argumentação a ser desenvolvida por escrito (na petição trabalhista).

O que chama à atenção, num primeiro momento, é a maneira como L1 orienta a fala de L2. L1 não explicita as razões pelas quais L2 deve alegar passar o cargo "sempre” para tais e tais pessoas. Não explicita porque ao fazê-lo negaria um preceito muito caro, ainda, ao Direito, que é o preceito da Verdade como algo absoluto. Se L1 explicitasse as razões pelas quais conduz a fala de L2 para que admita algo que não é exatamente uma Verdade absoluta, mas uma verdade construída discursivamente, L1 estaria ferindo tal preceito fundamental. De fato, os produtores do discurso jurídico sabem que argumentar juridicamente significa construir verdades discursivamente. Mas este é um fato que não se explicita, pois é a ilusão de verdade absoluta (e por conseguinte de imparcialidade e neutralidade das decisões judiciais) que está na base do Direito, assim como é reconhecido e valorizado em nossa sociedade, apesar das discussões, no próprio âmbito do Direito, sobre a noção de verdade.

O locutor advogado recorre, então, ao conhecimento de mundo do trabalhador para que este, cognitiva e pragmaticamente, compreenda o que está sendo proposto e co-construa o sentido na direção almejada. 
Quando L1 diz: “então passou a passar sempre, tá?”, fá-lo como enunciador 1, ou E1(L1), voz discursiva que revela que as verdades jurídicas podem ser construídas no discurso jurídico trabalhista, e não simplesmente reproduzidas da realidade empírica.

A seguir chama à atenção a resposta de L2: “hã?” . Em um primeiro momento, L2 não compreende o que está sendo proposto. Nesse instante, L2 enuncia como E1(L2), ou seja, fala a voz do trabalhador que desconhece não apenas o Direito trabalhista como ciência, mas também as sutilezas dessa esfera de atividade humana. Nessa fala, L2, na voz de E1, reconhece não pertencer à esfera jurídico-trabalhista.

L1 retoma a construção do texto imediatamente, repetindo a fala anterior, a fim de garantir que L2 a compreenda, o que de fato ocorre na última fala do trecho. Dela podemos depreender mais dois enunciadores de L2: o primeiro, evidenciado pela constatação “ah!...tá”, é E2(L2): a voz que revela um sujeito trabalhador mais inserido nas sutilezas do discurso jurídico trabalhista, e que aprendeu algo importante sobre sua construção. O segundo, evidenciado pela fala “Ha! Há!”, é E3(L2), enunciador que revela a voz de um trabalhador que, além de melhor conhecedor do discurso que ajuda a construir, é sujeito que sente satisfação ao ver-se inserido nessa construção e perceber-se beneficiado por ela.

Dessa forma, tem-se evidenciada a polifonia nesse pequeno trecho da seguinte forma:

$\mathbf{L 1}$ apresenta-se polifonicamente como:

$\mathrm{E} 1(\mathrm{~L} 1) \rightarrow$ voz discursiva que revela que as verdades jurídicas podem ser construídas no discurso.

L2 apresenta-se polifonicamente como:

E1(L2) $\rightarrow$ voz discursiva que revela desconhecimento das sutilezas da esfera jurídico trabalhista.

E2(L2) $\rightarrow$ voz discursiva que revela um sujeito trabalhador mais inserido nessa esfera. 


\section{E3(L2) $\rightarrow$ voz discursiva que revela um sujeito trabalhador satisfeito ao ver-se inserido nessa esfera e perceber-se beneficiado por ela.}

\subsubsection{Níveis de representatividade}

Graças ao efeito polifônico descrito acima, podemos apreender três importantes níveis de representatividade do sujeito trabalhador no gênero em questão. São três posições de sujeito distintas, mas complementares:

1. O sujeito trabalhador como cidadão comum, inserido no mundo do trabalho, mas alheio às peculiaridades do discurso jurídico trabalhista que lhe diz respeito. É o sujeito que diz: “Hã?”.

2. O sujeito trabalhador que se insere na esfera jurídico trabalhista, aprende na interlocução e pode reconstruir sua fala. É o sujeito que diz : “Ah!...tá”.

3. O sujeito trabalhador que se insere na esfera em pauta e satisfaz-se ao sentir-se beneficiado por ela. É o sujeito que ri: “Ha! Há!”.

Interessante notar que tais posições se consolidam durante e na interlocução com o locutor advogado, que, ao conduzir a construção do texto, participa também, como coenunciador do discurso, da construção desses diferentes níveis de representatividade.

\subsubsection{Interdiscursos}

Os três diferentes níveis de representatividade de L2 caracterizam respectivamente três interdiscursos que se interconstituem. Estes interdiscursos são os locais de onde fala o sujeito-trabalhador e que determinam as posições discursivas descritas acima. Tanto os níveis de representatividade como os interdiscursos podem variar em função da causa específica que move o processo trabalhista e em função do perfil dos interlocutores centrais (trabalhador, advogado e juiz). No caso específico desta análise, temos, no que se refere a L2: 
- O interdiscurso do cidadão comum, inserido no mundo do trabalho, mas alheio às peculiaridades do discurso jurídico trabalhista que lhe diz respeito.

- O interdiscurso do sujeito trabalhador que se insere na esfera jurídico trabalhista, aprende na interlocução e pode reconstruir sua fala.

- O interdiscurso do sujeito trabalhador que se insere na esfera em pauta e satisfazse ao sentir-se beneficiado por ela.

Os níveis de representatividade são, assim determinados pelo local de onde fala o sujeito, ou seja, são determinados pelo interdiscurso. Os gêneros discursivos em geral, e os dois estudados em particular, são, por sua vez, a materialidade discursiva que coage a construção, na prática da interlocução, dos níveis de representatividade e dos interdiscursos correspondentes. Os gêneros, em outras palavras, ao induzirem à construção de uma cenografia que lhes é típica, são a porta de entrada para a compreensão dessa mútua determinação.

Pode-se resumidamente afirmar que, nesta análise de fragmento do texto pertencente ao gênero entrevista trabalhador-advogado:

- L1, por coerção genérica, busca conduzir a fala de L2.

- Igualmente por coerção genérica, L2 se deixa conduzir, pois reconhece que a condução da construção de sentido em andamento deve ser feita por especialista.

- As falas de L1 e L2 não são homogêneas. A polifonia traz à tona níveis de representatividade distintos.

- Os diferentes níveis de representatividade apreendidos na fala de L2 apontam para diferentes interdiscursos, que são os locais de onde fala o sujeito trabalhador.

O fragmento analisado pode ajudar a mostrar que no gênero entrevista trabalhadoradvogado, o sujeito discursivo trabalhador apresenta-se como dono de sua fala, podendo legitimamente modulá-la e refazê-la em discurso. 
5.3 Gênero petição trabalhista: o sujeito discursivo trabalhador cede voz

\subsubsection{Efeito monofonizante}

Processo paralelo, mas construído a partir de outro paradigma, ocorre com a petição trabalhista enquanto gênero discursivo institucional no qual faz-se ouvir a voz do trabalhador.

Antes de aprofundarmos o que é necessário neste item, convém reforçar a descrição do que é a petição trabalhista. A petição é o documento inicial e central do processo trabalhista, na medida em que é através dele que o juiz toma conhecimento da causa. É ainda baseado nele que o juiz irá conduzir a audiência e realizar o julgamento propriamente dito. É na petição que se encontra toda a argumentação feita pelo advogado em prol do trabalhador. Esta argumentação é desenvolvida com base: (i) no conhecimento específico que o advogado tem sobre direito trabalhista; (ii) no conhecimento que possui a respeito do gênero petição e suas coerções de acordo com a esfera do direito trabalhista; e (iii) as informações obtidas na entrevista com o trabalhador.

A petição trabalhista é o único documento escrito (e legal, já que apenas os documentos escritos compõem os documentos legais) que apresenta a explicitação detalhada da causa por que luta o trabalhador e, portanto, traz manifesta a sua voz.

Diferentemente da entrevista, a petição não se caracteriza pela assimetria dos locutores, que fomenta um primeiro nível de polifonia. Caracteriza-se, sim, pelas estratégias de monofonização, que transformarão o locutor-advogado na única voz visível na superfície discursiva, ao menos em uma leitura analítica inicial. 
Aprofundemos a análise do trecho abaixo, já visto anteriormente, extraído da petição original, tendo-se em vista que: L1 = figura discursiva do advogado e L2 = figura discursiva do trabalhador.

No exercício da função de Caixa, subordinava-se à jornada contratual de 6 (seis) horas diárias, com início às 07 h00 e término às 13h00, isto de Segunda às Sextas-feiras, usufruindo de intervalo para descanso de 15 minutos. Fato é que o reclamante iniciava seu expediente em média às 06h00 e encerrava-o às 14h00. Todavia, por exigência do Banco-reclamado, lhe era obrigado a assinalar em folha de freqüência o horário contratual, jamais a efetiva jornada laboral prestada além daquele horário, conforme demonstrará provado em instrução processual. (grifos meus)

Consideramos como L1 o sujeito de discurso advogado, que constrói o texto e desenvolve a argumentação. Por coerções de gênero, L1 adota um tipo de linguagem própria ao discurso jurídico trabalhista, utilizando a sintaxe própria à petição, assim como o léxico adequado. L1 constrói o texto criando a ilusão de sentido do verdadeiro. L1 posiciona-se como aquele que descreve de forma objetiva fatos externos ao discurso, de tal modo que o juiz não terá como negá-los, exceto se a contra-argumentação desenvolvida pelo advogado do Banco na futura audiência puder neutralizar os esforços argumentativos da petição.

Aqui observamos o primeiro deslocamento de paradigma em relação à entrevista: L1 não se dirige mais a L2, mas à figura discursiva do juiz (L3). A petição tem na figura discursiva do juiz o seu interlocutor. As transformações na ordem da sintaxe e do léxico, se comparados os dois gêneros (entrevista e petição), ocorrem para satisfazer a esta mudança de interlocutor, que determina, de fato, a construção do gênero petição trabalhista. L1, assim, ao dirigir-se ao juiz, articula-se como E2(L1) no discurso jurídico trabalhista.

O trabalhador, L2 na entrevista, deixa de inserir-se no eixo dialógico EU X TU para constituir-se como ELE na petição trabalhista. Os trechos grifados na petição (exceto o 
enunciado final) correspondem aos elementos lingüístico-discursivos do trecho em pauta que atestam a presença deste ELE. O trabalhador passa a ser, na petição trabalhista, o ELE a quem o locutor-advogado se refere. E aqui observamos a segunda característica do paradigma próprio que rege a construção da petição: destituído de sua voz, o trabalhador passa a ser apenas referido. Trata-se de um ELE posto à margem da relação interlocutiva e deslocado para a qualidade de referente e referido.

Este deslocamento de L2 a uma posição enunciativa fora do eixo dialógico EU X TU é a principal estratégia de monofonização que o gênero petição trabalhista impõe. Os trechos sublinhados mencionados, no entanto, são as marcas lingüísticas que atestam a presença deste enunciador (ELE, o requerente), que chamaremos de E4, e que passará a constituirse como mais um nível de representatividade discursiva de L2, ou seja, E4(L2).

O enunciado grifado ao final do trecho (“conforme demonstrará provado em instrução

processual”) faz entrever um novo enunciador para L1. É o ponto de vista do locutor advogado que se volta para o combinado na entrevista inicial com seu trabalhador e expõe ao juiz, entre outros fatos, o fato de que as testemunhas arroladas no processo recebiam o cargo do trabalhador-requerente todos os dias. Podemos chamar de E3(L1) a esta voz que dialoga com o gênero anterior, interdiscursivamente.

\subsubsection{Níveis de representatividade}

E4(L2) é, assim, o enunciador que atesta a posição de sujeito apagado e excluído da interlocução direta. E4(L2) é posição discursiva autorizada por L2, que projeta sua fala na voz de L1. Ao autorizar L1 a falar por ele, L2 consolida sua posição de sujeito discursivo alheio à esfera jurídico trabalhista.

L1, por sua vez, enuncia, como vimos, como E2(L1), na medida em que se articula discursivamente como interlocutor do juiz, de acordo com o gênero petição trabalhista; e como E3(L1) - na medida em que faz entrever a interlocução com o sujeito-trabalhador, ao referir-se à instrução processual que ganhou corpo em função do diálogo estabelecido 
na entrevista inicial. Em síntese, o locutor-advogado, na petição trabalhista, articula-se primordialmente como interlocutor do juiz - E2(L1) - e secundariamente como interlocutor do trabalhador.

Dessa forma, tem-se evidenciada a polifonia nesse pequeno trecho da seguinte forma:

L1 apresenta-se polifonicamente como:

E2(L1) $\rightarrow$ voz que revela a figura discursiva do advogado em pleno exercício de seu saber específico, dirigindo-se ao juiz (L3) de acordo com as coerções do gênero petição trabalhista.

E3(L1) $\rightarrow$ voz que revela a figura discursiva do advogado em diálogo com L2.

L2 apresenta-se polifonicamente como:

E4 (L2) $\rightarrow$ voz que revela um sujeito discursivo posto à margem da interlocução, excluído do eixo dialógico EU X TU, e referido como ELE (requerente ou reclamante, e não como trabalhador)

\subsubsection{Interdiscursos}

A polifonia apreensível em E4(L2) revela o interdiscurso do sujeito-trabalhador excluído da interlocução direta no gênero petição trabalhista e no próprio discurso jurídico trabalhista, dada a importância do gênero petição nesse discurso. Como se vê, a presença de tal interdiscurso resiste à mais dura estratégia de monofonização. Tal apreensão se dá pela própria constatação da supressão da fala de L2 que, excluído como sujeito discursivo ativo na esfera jurídica trabalhista, passa a ser apenas referido.

Este nível de representatividade de L2 é próprio da petição trabalhista e caracteriza um dos interdiscursos determinados pelo gênero petição. Tal interdiscurso mostra um sujeitotrabalhador que fala de fora do discurso jurídico trabalhista. Dentro dele, é referido. 
Assim, no caso específico desta análise, temos, no que se refere a L2 (foco desta pesquisa), mais um interdiscurso:

- O interdiscurso do sujeito posto à margem da interlocução direta no discurso jurídico trabalhista, excluído do eixo dialógico EU X TU, e referido como ELE (requerente ou reclamante, e não como trabalhador).

Pode-se resumidamente afirmar, com base nesta análise do fragmento do texto pertencente ao gênero discursivo petição trabalhista, que:

- L1, por coerção genérica, constrói o texto suprimindo a fala de L2.

- Esta supressão dá-se via projeção da voz do trabalhador na voz do locutoradvogado (o advogado é a figura autorizada a falar pelo trabalhador), estritamente de acordo com as coerções do gênero.

- As falas de L1 e L2 não são homogêneas. A polifonia traz à tona níveis de representatividade distintos.

Os diferentes níveis de representatividade apreendidos na fala de L2 apontam para diferentes interdiscursos, que são os locais de onde fala o sujeito trabalhador.

O fragmento de texto analisado pode ajudar a mostrar que, no gênero petição trabalhista, o sujeito discursivo trabalhador deixa de apresentar-se como dono de sua fala, aparecendo como aquele que cede sua voz ao advogado. É categorizado como sujeito que requer, pede, sendo referido como "reclamante", e não como trabalhador. Mais significativo é o fato de não poder, neste gênero, modular ou refazer sua fala em discurso. 
5.4 A voz do trabalhador construída na petição trabalhista

A percepção inicial que se tem ao ler pela primeira vez uma petição trabalhista, mesmo sem se ter em vista o quadro que se esboçou sobre o que seja Direito, discurso jurídico e o próprio gênero petição, é a de que tais textos se constroem, como todo texto jurídico, como unidades estanques e unívocas, pois consolidam uma posição que pretende ser verdadeira e incontestável, criando a ilusão do sujeito homogêneo. O ponto de vista predominante é o do locutor-advogado, que faz as vezes do trabalhador perante as instâncias que deverão fazer valer, ou não, o direito requerido.

De fato, é esta a percepção que o texto pretende provocar, e não de forma ingênua. Nesta análise, veremos como tal efeito de sentido é construído na petição trabalhista, levandose em conta que a petição está sendo aqui considerada como gênero decorrente de outro gênero, anterior e sem valor legal: a entrevista entre trabalhador e advogado.

O que, a nosso ver, chama a atenção e caracteriza a petição trabalhista é a estratégia discursiva de se utilizar expressões referenciais definidas para fazer menção ao trabalhador. A voz do trabalhador não se manifesta por si, mas apenas e tão somente através da voz do locutor-advogado. Ao trabalhador não é dada a palavra sequer uma vez. A argumentação é tecida em nome dele e não por ele. O trabalhador ocupa o modesto lugar de $3^{\mathrm{a}}$.pessoa do discurso, aquela de quem se fala. Se não fala por si, clara está sua posição de dependência e submissão, como se depreende da fórmula com a qual todas as petições são iniciadas, com poucas variações: "FULANO DE TAL, ........, vem com o devido respeito e acato a Vossa Excelência propor a presente RECLAMAÇÃO TRABALHISTA ...” etc, etc.

O trabalhador aparece em tais textos como alguém a que se faz referência. Afora a menção de seu nome no início da petição, no decorrer do texto é designado por alguns termos-chave do discurso jurídico, que a análise que segue se encarregará de mostrar. 


\subsubsection{Referenciação na petição trabalhista: apagamento do sujeito trabalhador?}

De acordo com o paradigma idealista, a linguagem seria capaz de referenciar diretamente os objetos do mundo. No entanto, o que ocorre, em nossa perspectiva, é que a linguagem cria objetos do mundo, que tomam existência palpável no texto, discursivamente. Koch e Marcuschi (1998) assumem uma postura sobre a referência (ou referenciação), que é a que nos interessa aqui, que considera o fenômeno menos como um ato de ostenção direta entre linguagem e mundo, e mais como um ato de construção de pistas - calcadas de algum modo na experiência empírica - que possibilitariam o acesso a inferenciações e elaboração de sentidos. Com Marcuschi, consideramos que a referenciação oferece as pistas de acesso à atualização de domínios cognitivos que estabelecem correspondências com o mundo para comunicação intersubjetiva dessas correspondências. Aspectos como conhecimento partilhado e situacionalidade - que garantem a coerência textual constituem-se, nessa perspectiva, condição de acessibilidade e não base para elaboração de regras de formação textual.

O texto jurídico, assim, disponibiliza ao leitor o acesso a sentidos coerentes com o paradigma do discurso jurídico. Não há como fugir disto, mas apenas estar-se consciente do jogo simbólico que se instala a cada interação e perceber que a realidade em si passa a ser algo secundário, algo em que o jogo simbólico se calca, mas a que não se remete diretamente. Ao alegar o que quer que seja em defesa do sujeito discursivo trabalhador, o locutor-advogado simboliza determinada realidade, revestindo-a do caráter de verdade empírica (mas é de fato discursiva), com o objetivo de fazer o leitor percorrer determinada direção argumentativa, e não outra, que levará a determinados sentidos, os quais só podem ser apreendidos se o leitor entrar no jogo, acionando pela cognição o paradigma adequado.

As petições trabalhistas apresentam a peculiaridade de criar certo efeito de sentido através de um processo de referenciação no qual o referente "trabalhador” é posto como elemento externo ao texto, e que é continuamente retomado por várias expressões próprias ao jargão jurídico. Referido como um “ele” externo ao texto, o sujeito trabalhador permanece 
afastado do processo, não possuidor de sua palavra, distante ser do mundo real para o qual se aponta, mas que não se traz para dentro da interlocução. A análise aprofundará este ponto, mostrando como, através da referenciação anafórica, a voz do trabalhador se constitui na petição trabalhista.

Convém lembrar que a noção convencional de anáfora considera-a apenas como retomada explícita de antecedente por repetição de item ou construção lingüística, de forma estável e com continuidade referencial. O antecedente pode ainda ser retomado por um pronome, sem alterar a relação de estabilidade e continuidade. No entanto, a análise dos usos tem demonstrado que o processo é mais complicado, e que para se entender as possibilidades anafóricas correntes é preciso ampliar a noção de referência, conforme estudos atuais de Marcuschi (1998, 1999) e Koch e Marcuschi (1998). Para tais autores, é preciso pressupor uma noção não realista de referência, uma conceituação que não postule os objetos referidos como objetos do mundo, mas como objetos de discurso, uma vez que não são exceção os casos em que não há referência alguma entre anáfora e antecedente textual. Para nós é importante a noção de anáfora pressuposicional, cuja apreensão depende de condições que superam o nível do estritamente lingüístico, exigindo o acionamento pragmático-cognitivo de processos lingüísticos e extralingüísticos para que haja o melhor entendimento.

Desta forma, pode-se dizer que a anáfora se dá no uso da língua em situações discursivas contextualizadas. Não há anáfora sem contexto. A noção de anáfora que nos interessa engloba o seguinte: como sistema de acessibilidade referencial, ela pode remeter, refazer, acrescentar algo ao texto, numa progressão que mostra ao leitor o que deve considerar na continuidade, sempre num nível discursivo. A anáfora organiza relações entre referentes a partir de suposições dos produtores e receptores de discurso, não sendo, portanto, de forma alguma autônoma, nem estando necessariamente atrelada à existência de antecedentes textuais explícitos. Desta forma, o estudo da anáfora é mais fértil se desenvolvido de um ponto de vista discursivo e pragmático. 
Destes pontos de vista, as ocorrências anafóricas que mais chamam atenção na petição (ou seja, certas expressões referenciais definidas, conforme se verá em item seguinte) são marcas textuais polifônicas, que remetem aos interdiscursos constitutivos do discurso jurídico trabalhista (conforme descritos nos itens anteriores) e apontam para níveis de representatividade específicos.

\subsubsection{Anáfora e polifonia: expressões referenciais definidas na petição trabalhista}

As expressões referenciais definidas são consideradas neste trabalho não apenas o processo anafórico predominante na petição, como também - e por conseguinte - como o mais importante processo de construção do sentido. Elas são elementos centrais para criar uma cenografia própria ao gênero, que evoca no leitor uma determinada imagem do sujeito trabalhador.

Segundo Koch (1998), as expressões referenciais definidas podem constituir-se como nominalização e como descrição nominal definida. Nominalização seria um tipo de expressão referencial definida "através da qual se referencia, por intermédio de um sintagma nominal (freqüentemente um nome deverbal), um processo ou estado anteriormente expresso por meio de uma proposição...”; “ (a nominalização) erige em referentes ou objetos de discurso conjuntos de informações expressas no texto precedente, que anteriormente não possuíam tal estatuto”. A descrição nominal definida, por sua vez, se caracterizaria por operar uma seleção dentre as propriedades do referente (reais, co(n)textuais ou intencionalmente atribuídas pelo locutor) para construir este mesmo referente dentro de uma determinada direção argumentativa. Em geral, constituise de lexema precedido de determinante.

Para efeito deste estudo, não distinguimos um e outro tipo de expressão referencial. Consideramos tanto a descrição nominal definida como a nominalização processos anafóricos que implicam uma escolha entre propriedades ou qualidades capazes de caracterizar o referente, escolha esta dependente do contexto e dos objetivos a serem atingidos pelo produtor do texto, que cria sentidos novos, não meramente reproduz a realidade externa ao texto, seja qual for a definição escolhida para "realidade”. Mais do que ativar no leitor conhecimentos supostamente partilhados, as expressões referenciais 
definidas, no caso dos textos analisados, vão funcionar como uma maneira de deslocar para dentro do universo discursivo o elemento "trabalhador" transfigurado em enunciador-solicitante, mesmo assim de forma indireta, através de um locutor-advogado. O sujeito discursivo que se manifesta no gênero entrevista é destituído de sua condição de trabalhador, para assumir a função discursiva de solicitante de um suposto direito. Assim, destacam-se nos textos de petição em geral termos como: "embargante", “reclamante” e "recorrente”, que aparecem como expressões anafóricas de um sujeito que possui nome próprio mencionado apenas no início da petição, mais para que se identifique o processo jurídico em questão e menos para que se identifique o sujeito deste mesmo processo.

Vale observar que não se trata de referenciar aqui um processo ou estado anteriormente expresso em uma proposição, mas sim de referenciar um sujeito descaracterizado de sua função de sujeito, estrategicamente nivelado a processo ou estado, e assim desfigurado e apropriado por um discurso que por princípio existe para beneficiá-lo.

A escolha dos termos utilizados para referenciar o trabalhador, embora justificada por uma suposta necessidade de se manter o jargão jurídico, em princípio o mais preciso para a situação (de fato, há coerência entre o jargão utilizado e o paradigma jurídico que se alinha ao discurso do poder), traz implícito o viés ideológico que reduz o sujeito de um direito a sujeito pedinte de um direito, o que aparentemente serve para manter o desnivelamento entre empregado $\mathrm{x}$ empregador, seja qual for a decisão judicial.

Ao se atribuir expressões como "reclamante” e "recorrente”, procede-se a um processo de recategorização do elemento referenciado, que é distanciado do universo do discurso empresarial onde se trava o embate das forças e posicionado no universo idealizado do discurso jurídico, em que aparentemente não há contradição, apenas a luta justa e transparente por um direito perdido ou ameaçado.

A orientação argumentativa que esta referenciação propõe, ao recategorizar o referente dentro do universo jurídico, que de fato não é o dele, é a de marcar este mesmo e único sentido de desnivelamento, sentido mascarado sob uma ideologia naturalizada, para a qual é "fato incontestável do mundo empírico" a distribuição desigual de poder. A 
expressão referencial definida encapsula o elemento referido, sumariza-o, para além do nível estritamente morfossintático. Num sentido discursivo e também pragmáticocognitivo, a expressão referencial definida no texto estudado reduz o sujeito a uma ínfima parte do que ele é, ou, pior, do que ele é levado a ser.

Esta redução contribui, assim, para o apagamento do sujeito trabalhador enquanto tal, e, na mesma medida, generaliza um certo sentido de trabalhador cristalizado no discurso jurídico trabalhista que nubla as relações pessoa-pessoa. Não se trata, então, de sujeitos em relação, mas de categorias em conflito (trabalho x capital; empregado x empregador).

Quand vous désignez tout un group de personnes par un terme unique, comme par exemple musulmans, vous agissez comme pour vous en débarrasser: vous ne savez plus distinguer chaque individu. Le nom, le mot vous aura ainsi empeché d'agir comme un être humain en relation avec d'autres êtres humains. ${ }^{48}$

Embora não constem no texto analisado, expressões referenciais definidas do tipo “autor”, acompanhadas do definido “o”, exercerão o mesmo papel, alinhando-se à direção argumentativa geral. Registramos em leituras de outras petições o uso do referente "obreiro”, que parece provocar um certo desvio nesta orientação geral. Embora não conste no texto analisado expressão que funcione de modo igual ou similar, a possibilidade de sua ocorrência será levada em conta na análise.

Procederemos a seguir ao levantamento das ocorrências anafóricas do tipo expressão referencial definida em três petições para, a seguir, analisarmos as ocorrências na petição referente ao processo em pauta. O objetivo de se incluir textos alheios ao processo trabalhista escolhido é ampliar a análise e facilitar a percepção de como se dá, neste gênero, a abertura à polifonia, evidenciando-se a tensão entre efeitos monofonizantes e efeitos polifônicos. Ao final deste item, trataremos de observar como a cessão da voz do trabalhador ao advogado não é definitiva e o que isto pode significar em termos de construção do sentido da voz do trabalhador neste discurso.

\footnotetext{
${ }^{48}$ Tradução livre para o francês da obra de Krishnamurti, Reflectins on the self, Raymond Martin, Chicago, Open Court, 1997, apud Rahnema (2003). Em português, tradução aproximada: quando designamos todo um grupo de pessoas por um termo único, como por exemplo muçulmanos, agimos como para nos desembaraçarmos: não sabemos mais distinguir cada indivíduo. O nome, a palavra, nos terá assim impedido de agir como um ser humano em relação com outros seres humanos.
} 
O texto 1 (ver Anexo C) é o único precedido por carta, que faz as vezes da introdução habitual. Como foi dito, neste momento da petição apresenta-se o trabalhador e a solicitação. Observamos que a referência anafórica através de expressão referencial definida foi realizada com as palavras "reclamante" e "recorrente" seis vezes no texto todo. A palavra "autor”, considerada aqui também uma expressão referencial definida e utilizada com o mesmo propósito, aparece três vezes. A palavra "empregado", designação mais próxima ao termo "trabalhador” (opondo-se a “empregador”, termo que designa o capital na legislação trabalhista), aparece cinco vezes no texto, mas não exatamente para referir o trabalhador cujo processo está em curso, mas sim para designar genericamente aquele que executa trabalho assalariado a certo empregador, conforme termos da lei trabalhista mencionada nos parágrafos em que o termo "empregado" aparece. O termo “empregado” refere-se mais, nesta petição, aos termos utilizados na lei trabalhista, numa espécie de citação indireta, e menos à pessoa do trabalhador em questão.

O termo “obreiro” foi utilizado uma única vez (parágrafo 12), justamente em um cotexto de passagem entre uma parte da argumentação em que se propõe a nulidade do julgado (até o parágrafo 11) para outra em que, para demonstrar o mérito da questão, se adentra a lei trabalhista (parágrafo 12 em diante). Até o parágrafo 11, a referência é feita através dos termos “recorrente” e “reclamante”, além de “autor”. No parágrafo 12 introduz-se o termo “obreiro" (ocorrência única) e o termo “empregado”, que faz referência indireta ao trabalhador, referindo-se diretamente, isto sim, a um sujeito abstrato mencionado na legislação e que se opõe ao termo "empregador". De fato, apenas o termo "obreiro" designa, a nosso ver, o sujeito ativo trabalhador, e este só aparece uma vez.

Apenas uma vez foi utilizada a expressão referencial: "parte contra a qual foi produzido o documento" (parágrafo 3), que, tal qual as designações “recorrente” e "reclamante”, desloca o sujeito trabalhador de sua função de ser social e produtivo, recategorizando-o como mero co-enunciador de um discurso que não pode conduzir por pretensa incompetência jurídica. O jargão jurídico fartamente utilizado em todo o texto nada mais é do que a materialização lingüística de um poder não-compartilhado, que não pertence ao trabalhador. 
Observe-se o quadro abaixo:

\begin{tabular}{|lcc|}
\hline \multicolumn{3}{|c|}{ QUADRO I - EXPRESSÕES REFERENCIAIS DEFINIDAS QUE } \\
CONSTROEM O SUJEITO TRABALHADOR NO TEXTO 1
\end{tabular}

\section{Texto 2:}

Neste texto, a escolha lexical recai sobre os termos “autor” e “embargante”. Este último assume significado próximo ao de "recorrente”, pois denota a existência de uma ação que deve ser impedida - uma vez que fere os direitos do trabalhador, o que será tentado pela voz do locutor-advogado. A postura de trabalhador pedinte, mais claramente expressa no termo "reclamante”, continua presente. A percepção desta similaridade entre os termos só se dá através da adoção de uma perspectiva pragmática durante a leitura, não apenas semântica. Cognitivamente, o leitor estabelece as relações contextuais cabíveis e aciona seu conhecimento prévio (via memória discursiva) referente aos discursos do mundo do trabalho, podendo assim perceber as correlações entre os termos e qual o efeito de sentido predominante. Poderíamos dizer que a variedade de termos selecionados para referenciar dá-se mais em função de se criar um estilo de texto menos repetitivo e monótono e menos por ser necessário novo enquadramento do referente. De fato, este permanece essencialmente o mesmo em todos os textos: um sujeito apagado, deslocado para dentro de um discurso onde pressente poder fazer ecoar sua voz, mas onde não pode fazer valer seus conhecimentos específicos de trabalhador, vendo-se por fim obrigado a utilizar-se via advogado de um saber jurídico que não detém, com o objetivo último de preservar sua identidade de sujeito trabalhador detentor, em princípio, de certos direitos. 


\begin{tabular}{|lcc|}
\hline \multicolumn{3}{|c|}{ QUADRO II - EXPRESSÕES REFERENCIAIS DEFINIDAS QUE } \\
CONSTROEM O SUJEITO TRABALHADOR NO TEXTO 2 \\
DESIGNAÇÃO & PARÁGRAFOS & TOTAL DE OCORRÊNCIAS \\
Embargante & 2 e 8 & 2 \\
Autor & 6 e 8 & 3 \\
\hline
\end{tabular}

\section{Texto 3:}

Neste texto predomina o termo anafórico "reclamante", com toda a carga de significado já explorada. Aparecem ainda o termo “autor” e o termo “montador”. Este último, tal como a palavra "obreiro" no texto 1 , remete diretamente à figura central da petição, o trabalhador, para restabelecer, nem que de forma esporádica nos textos, e talvez por um lapso do locutor, a memória de um sujeito trabalhador ativo, diferente do sujeito passivo, com papel de coadjuvante no discurso jurídico em que foi inserido. Parece-nos que, pelo número de ocorrências de um termo e outro, este sujeito passivo, pedinte de um direito mais do que dono deste direito, é a extensão discursiva do sujeito trabalhador do mundo empírico, e não o sujeito ativo intuído em “obreiro” ou “montador”.

\begin{tabular}{|lcc|}
\hline QUADRO III - EXPRESSÕES REFERENCIAIS DEFINIDAS QUE CONSTROEM O \\
SUJEITO TRABALHADOR NO TEXTO 3 \\
DESIGNAÇÃO & PARÁGRAFOS & TOTAL DE OCORRÊNCIAS \\
Reclamante & $2,3,4,5,6,7$ e 9 & 8 \\
Autor & 10 & 1 \\
\hline
\end{tabular}

Já na petição inicial para ressarcimento de hora-extra pertencente ao processo trabalhista estudado, observamos que a expressão referencial definida utilizada é “reclamante”, que aparece 12 vezes no texto, em quase todos os parágrafos. Não há outras expressões referenciais definidas, como ocorre nos demais textos. 
Assim temos:

\begin{tabular}{|c|c|c|}
\hline \multicolumn{3}{|c|}{ QUADRO IV - EXPRESSÕES REFERENCIAIS DEFINIDAS QUE CONSTROEM O } \\
\hline \multicolumn{3}{|c|}{ SUJEITO TRABALHADOR NA PETIÇÃO DE RESSARCIMENTO DE HORA- } \\
\hline \multicolumn{3}{|c|}{ EXTRA } \\
\hline DESIGNAÇÃO & PARÁGRAFOS & TOTAL DE OCORRÊNCIAS \\
\hline Reclamante & $2,4,5,7,9,10,11$ & 12 \\
\hline & $12,16,17,21,22$ & \\
\hline
\end{tabular}

Pode-se afirmar que a anáfora na petição, sob a forma de expressões referenciais definidas, são marcas polifônicas que constituem a interdiscursividade do gênero. Reforçamos que não se trata de uma referenciação meramente textual, mas sim de uma referenciação que remete ao interdiscurso, por um lado, e por outro remete àquele sujeito discursivo construído na entrevista inicial, recategorizando-o. O interdiscurso, que é social, revela um sujeito discursivo que “abaixa a voz” e tende a se apagar por trás da figura do locutor-advogado (efeito monofonizante). O sujeito discursivo recategorizado (referido por "reclamante”), ao ser apreendido como um dos níveis de representatividade discursiva do sujeito trabalhador, aponta para as diferentes constituições desse sujeito (efeito polifônico).

Ao que indica a quantidade de ocorrências das designações anafóricas do tipo expressão referencial definida que constroem o referente trabalhador, e tendo em vista o pano de fundo necessário para viabilizar esta forma de olhar tais textos, a saber, o conhecimento 
prévio do que seja o discurso jurídico e o gênero petição, tendo-se ainda em vista o quadro mais amplo das relações capital x trabalho em nossa sociedade capitalista, binômio que constitui o próprio universo do trabalho, é possível afirmar que a petição trabalhista, aparentemente gênero predominantemente monológico, parece ser um dos poucos documentos institucionalizados em que se faz presente a voz do sujeito trabalhador, embora de forma indireta e construída dentro do paradigma idealista de um Direito positivo.

As representações construídas através da apreensão do interdiscurso - apreensível graças ao efeito polifônico derivado do uso da expressão referencial definida "reclamante" levam-nos a pressupor qual seja o papel do sujeito discursivo trabalhador, em uma sociedade que muito tem que caminhar para equacionar melhor as relações de poder. Um novo estatuto para o sujeito trabalhador passaria, a nosso ver, pela renovação da instituição Direito do Trabalho, de modo a que absorvesse a complexidade do mundo do trabalho hoje e lidasse de forma produtiva com suas contradições, respeitada a vocação para a paz social do discurso jurídico.

Parece-nos possível afirmar que a cessão da voz do sujeito discursivo trabalhador ao locutor-advogado presente na petição indica simultaneamente apagamento e presença. Trata-se de uma simultaneidade coerente com o paradigma do discurso jurídico e com os discursos do mundo do trabalho em nosso país.

Como produto de certa cultura - calcada na realidade externa ao texto em que emerge, o discurso jurídico construído nas petições trabalhistas tem se mostrado o espaço discursivo em que a voz do trabalhador encontra algum eco, embora contida por estratégias que a colocam em plano subalterno. Tais estratégias desnudam um sujeito trabalhador deslocado de seu contexto de ação social, envolvido contingencialmente em um discurso cujo jargão não domina e ao qual se submete objetivando ver atendida sua solicitação perante a lei (o poder instituído). Esta, pretensamente acima do conflito capital $\mathrm{x}$ trabalho, teria o poder de equacionar o desnivelamento entre ambos, tarefa que cumpre apenas circunstancialmente, e não estruturalmente, uma vez que se alinha às forças do capital de que é produto. 
5.5 A audiência trabalhista como prática discursiva triangular

Embora não nos tenha sido possível gravar a audiência referente ao processo trabalhista cujos gêneros centrais analisamos neste trabalho (ver metodologia) - o que inviabilizou uma análise lingüístico-discursiva detalhada apoiada em sua textualidade - sua prototipicidade, apontada pelos advogados que nos orientaram, permite-nos generalizar alguns pontos que norteiam a constituição do gênero audiência. Permite-nos ainda, com base em anotações que fizemos durante a observação da mencionada audiência, dar continuidade ao trabalho de rastrear a representatividade discursiva da voz do sujeito trabalhador no discurso jurídico trabalhista. Como dissemos no item 4.1 (Gêneros jurídicos), o trabalho de Di Fanti (2004), em que a autora realiza descrição detalhada do que chamou de sintaxe enunciativo-discursiva da audiência trabalhista, deu-nos a base necessária para as teorizações do dito capítulo e para as considerações a seguir.

A petição como gênero norteador da audiência trabalhista

A petição, considerada como o documento central no processo trabalhista - pois nela se encontra formalizada a voz do trabalhador (sob forma de queixa trabalhista) - pode ser considerada como ato de fala central no processo também porque é apenas a partir dela que o juiz, em audiência, poderá exercer o ato subseqüente e final - o ato de julgar, não se considerando para efeito de emissão da sentença nada que na petição não se tenha feito constar expressamente. Conforme Di Fanti (2004):

Podemos entender que é a partir da petição inicial, documento em que são registrados os pedidos a serem ressarcidos, que a audiência se desenvolve. Com isso, se não constar algum pedido na petição inicial, não haverá possibilidade de solicitá-lo em outro momento no processo em tramitação. (p. 290)

É próprio ao gênero audiência trabalhista, portanto, fortemente institucionalizado, desenrolar-se unicamente a partir do expressamente verbalizado na petição, desconsiderando o que for dito em audiência que não tenha já sido dito na petição ou que seja contraditório ao que nela consta. 
O juiz, ao acatar a petição, acata a voz do trabalhador nela representada pela voz do locutor-advogado que, como já foi mostrado, projeta a fala do trabalhador a partir da sua fala especializada. Desta forma, a prática discursiva do trabalhador em audiência, embora possa dar-se sem a intermediação do advogado trabalhista, ganha novo limite: os termos da petição.

Se a voz do trabalhador deixa de dever ser expressamente representada pelo locutoradvogado, ela só terá valor legal - ou, de um ponto de vista discursivo-pragmático, só adquirirá efeito de ato - através de uma nova intermediação discursiva: a do juiz, que valida a fala se considerá-la adequada aos termos da petição, permitindo que seja registrada pelo escrivão (desde que nos termos por ele - juiz - determinados).

É essencial na prática discursiva das audiências trabalhistas, para que os registros tenham valor legal, a centralidade da figura do juiz, a quem cabe não só perguntar, como também reproduzir as respostas dadas pelas partes litigantes e seus advogados para que sejam registradas pelo escrivão da forma como ele - o juiz - as emite, e não da forma como originalmente foram enunciadas.

Assim é que, na audiência observada, quando o reclamante declara que não tinha hora de almoço e acabava comendo um lanche no próprio guichê do caixa, o enunciado registrado, com valor legal, foi: "o reclamante alimentava-se trabalhando”, conforme reformulação feita pela juíza. Observa-se que aqui ocorre processo paralelo ao ocorrido na formulação dos enunciados da petição, em que se retextualizam enunciados do sujeito trabalhador de acordo com coerções próprias ao gênero de destino. Há uma espécie de paráfrase com efeito de síntese, em que a linguagem informal e leiga do sujeito trabalhador é substituída por uma linguagem mais formal e impregnada pelo jargão jurídico.

Desta maneira, o estatuto discursivo da voz do trabalhador adquire, na audiência, uma força restritiva singular, paralela à força exercida sobre sua fala na elaboração da petição, mas com diferenças constitutivas que se devem explicitar. 
Na petição trabalhista, duas são as forças coercitivas que adequam a fala do sujeito trabalhador às restrições semânticas do discurso jurídico trabalhista:

(i) o conhecimento especializado em direito do trabalho do sujeito advogado, que conduz, na entrevista, o dizer do sujeito trabalhador, remodelando sua fala de acordo com o conhecimento das leis trabalhistas e do contexto sócio-histórico dentro do qual elas se articulam; e

(ii) o conhecimento prático do gênero petição, por parte do mesmo sujeito advogado, conhecimento tal que irá determinar a aceitação do pedido pelo juiz do trabalho e consolida a petição como ato de fala central no processo trabalhista.

Assim, num primeiro momento, têm-se constituídas na petição as figuras discursivas do locutor-advogado (EU), do trabalhador (ELE) e do juiz (TU), nos moldes de um processo interativo convencional, segundo o qual a comunicação verbal implica necessariamente um sujeito da enunciação que se atribui o pronome EU, um sujeito co-enunciador (TU) a quem se destina o enunciado e um objeto de referência alvo da relação comunicativa (ELE). Claro está, como já foi visto, que há na petição um desvio significativo deste padrão, uma vez que o ELE referido é de fato o EU do processo discursivo do litígio trabalhista.

Na audiência, por sua vez, as forças coercitivas que adequam a fala do sujeito trabalhador às restrições semânticas do discurso jurídico trabalhista têm natureza diversa. Tais forças são:

(i) a pressuposição, por parte do juiz, de que todos os participantes do processo possuem o conhecimento específico das regras que coagem o desenrolar da audiência trabalhista. O juiz, portanto, não fará a análise e o julgamento de tópicos não constantes na petição, o que significa poder limitar o dizer e validar ou não os enunciados que vierem a ser proferidos na audiência; e 
(ii) o poder do juiz de validar os enunciados proferidos pelas partes litigantes e seus advogados apenas após serem por ele - juiz - reformulados. O escrivão registra nos autos apenas as falas reformuladas pelo juiz, e não os enunciados originais.

Observamos que não apenas a fala do trabalhador é validada após reformulação pelo juiz na audiência, mas também a fala da reclamada e dos respectivos advogados, assim como das testemunhas eventualmente presentes. A nós interessa refletir sobre os efeitos dessa coerção na fala do sujeito discursivo trabalhador, tendo-se em conta não apenas sua fala na audiência, como também sua voz representada nos demais gêneros do processo trabalhista.

No que se refere, portanto, à voz do trabalhador, o que observamos na audiência é o estabelecimento de uma prática discursiva triangular, diferentemente do que ocorre na petição e na entrevista inicial. Nestes dois gêneros existe uma relação EU-TU que se desenrola tendo em vista a instância privilegiada de um ELE: o juiz, que representa o poder constituído e funciona como eixo condutor das falas do discurso jurídico trabalhista de acordo com as suas coerções, sendo ao mesmo tempo a instância pressuposta na construção da direção argumentativa. Na audiência, por sua vez, estabelece-se a comunicação entre EU e TU (reclamante e reclamada) com a intermediação direta de um EU (juiz), em presença, que, além de funcionar como instância pressuposta, atua como figura central e determinadora do estatuto legal das falas de EU-TU no tempo presente da enunciação.

O procedimento jurídico de prover os enunciados de estatuto legal constitui-se função discursiva que o juiz assume em prol da recuperação da tradição jurídica e da continuidade das idéias jurídicas. O cumprimento desta função garante a não-arbitrariedade da sentença, que deve se basear nas leis e na jurisprudência, ou seja, na memória sócio-histórica e discursiva. Por outro lado e concomitantemente, o juiz assume a função de julgar, e não apenas julgar, mas julgar um caso singular. Esta função promove a desregulação da memória discursiva e a abertura do discurso para o outro e para o novo, representados na audiência pelas figuras do reclamante e da reclamada e de seus representantes legais. 
Estes movimentos regulados pela figura do juiz, aparentemente contraditórios, são a manifestação da tensão interdiscursiva entre a tendência à monofonização e à polifonia. São movimentos que atestam a continuidade e a descontinuidade constitutivas do discurso. Dito de outro modo, atestam a interdiscursividade constitutiva da linguagem observável em situação real de uso da língua pelos falantes.

A triangulação da prática discursiva em audiência assume assim uma dupla direção: em direção ao passado, através do acionamento de uma memória discursiva que permite ao juiz atuar ancorado em consenso sócio-histórico em matéria de direito; e em direção ao futuro, através da desregulação da memória, promovida pela sua atualização no gênero de discurso audiência trabalhista.

Diálogo juiz X partes litigantes: interdiscurso e efeitos de antecipação

É na interação com as partes litigantes durante a audiência, ou seja, é na atualização do discurso jurídico trabalhista no gênero audiência trabalhista, que a figura discursiva do juiz pode assumir seu duplo papel. Assim, fazem parte da cena genérica os interdiscursos do trabalho constitutivos do sujeito discursivo trabalhador, com os quais o juiz necessariamente irá dialogar. Tais interdiscursos podem ser o interdiscurso sindical, o interdiscurso das práticas de trabalho específicas à especialidade do reclamante, o interdiscurso que traduz a relação que o sujeito estabelece com sua atividade e ambiente de trabalho, entre tantos outros.

Da mesma forma, a reclamada representa, na cena genérica audiência, os interdiscursos do mundo patronal, ou empresarial, que podem ser vários: o interdiscurso das multinacionais, o interdiscurso das pequenas empresas, o interdiscurso patronal referente à especialidade do empregador (por exemplo, o interdiscurso patronal dos bancos, que é diferente do interdiscurso patronal da indústria automobilística), etc.

No caso da audiência observada, algumas falas nos sinalizaram a presença de certos interdiscursos. A pergunta da juíza ao reclamante quanto à existência de plano de 
desligamento no banco em questão (a reclamada, como vimos, é um banco) nos remete a acordos sindicais e ao interdiscurso do sindicalismo. Ao ser indagado pela juíza, o reclamante mencionou que o recebimento de abonos era independente do recebimento pelas horas-extras realizadas, e este independente da obtenção de dias a mais de descanso. Esta menção também nos remete ao interdiscurso do sindicalismo, cuja ação é ainda bastante eficaz na esfera do trabalho em bancos.

O interdiscurso do trabalhador especializado aparece quando uma testemunha (colega de trabalho do reclamante) revela desconhecer a diferença entre "ausência abonada” e "abono assiduidade”. Observe-se aqui que o saber especializado do mundo do trabalho muitas vezes exclui o conhecimento dos direitos e deveres adquiridos em negociações promovidas pelo sindicato (ou afim) e a área de pessoal (ou afim) da instituição empregadora.

\section{Silêncio e interdiscurso}

Embora a tendência à monofonização do gênero iniba a explicitação das vozes, que são as marcas lingüísticas dos interdiscursos, elas surgem invariavelmente. O silêncio, o não-dito, é também uma pista lingüística que aponta para uma voz (e seu correspondente interdiscurso) que não ganhou materialidade. Assim é que o silêncio do sujeito trabalhador durante a audiência, bastante comum, não pode ser desprezado, mas sim caracterizado como marca de interdiscursividade.

Este silêncio é, por um lado, aspecto promovido pelo gênero. Toda a situação da audiência, inclusive o local físico onde ocorre, é intimidadora para o sujeito reclamante. Esta intimidação é recorrente e constitutiva do gênero petição, que promove a intimidação para marcar que o discurso jurídico trabalhista é um discurso de poder, como o é o discurso jurídico em geral. Por outro lado, trata-se de uma justiça que existe para assegurar os direitos dos trabalhadores, e assim o discurso abre-se para incluir a voz do trabalhador através das perguntas que o juiz faz diretamente ao reclamante. Ocorre que, no entanto, tais perguntas não dão margem à fala solta do trabalhador, mas apenas à confirmação ou não do que foi dito na petição. 
Na audiência analisada, o sujeito reclamante permaneceu calado quase todo o tempo. Sua fala limitou-se a respostas à juíza que buscava esclarecer aspectos pontuais da petição. Foram falas breves que, como de praxe, foram reformuladas pela juíza para efeito de registro por parte do escrivão.

Às perguntas da juíza:

“Como anotava seus horários de saída no livro de ponto?” e

“Recebia orientação para isso?”,

o sujeito trabalhador, no papel de reclamante, respondeu algo como:

“Tinha que anotar de um certo jeito, não era pra pôr o horário mesmo...” e

“Bem, tinha que ser assim, era como mandavam, o gerente, sabe?...”.

Respostas que foram reformuladas pela juíza da seguinte forma:

“O reclamante anotava incorretamente o horário de saída” e

“A determinação vinha da gerência”.

Duração da audiência e transformação do gênero

Importa assinalar que as audiências em geral, nas principais varas, duram a média de 15 minutos, o que significa um tempo muito pequeno para deliberações. Não há propriamente uma defesa de causa por parte do advogado, por exemplo, cuja função acaba se resumindo a: esclarecer ao juiz informações da petição; perguntar ao reclamante ou seu advogado (via intermediação e reformulação dos enunciados pelo juiz) sobre pontos referentes ao exposto na petição; ou realizar pedidos bastante específicos, permitidos por lei. É o que ocorreu ao final da audiência, quando o advogado da reclamada pediu à juíza que fizesse constar no Termo de Declaração uma pergunta feita por ele que foi indeferida pela juíza. 
Consideramos que a breve duração das audiências, justificada pela sobrecarga do poder judiciário trabalhista, é, ou tem se tornado, constitutiva do gênero, o que põe em risco a razão de sua própria existência, que é o julgamento adequado do pedido de defesa dos direitos do trabalhador. Com o tempo curto e o conseqüente agravamento dos riscos de incompreensão - ou (inter)incompreensão, como prefere Maingueneau (1984) - dos termos da petição, que acabam não sendo devidamente averiguados, as chances de um mau julgamento aumentam.

A tendência ao acordo, como aprofundaremos adiante, proposto logo no início de cada audiência, se por um lado visa agilizar as audiências, aumentando o número de casos resolvidos e "desafogando" a justiça trabalhista, por outro descaracteriza o gênero como espaço de averiguações e exposições necessárias ao ato de julgar. O fato é que o acordo, que vem se consolidando como novo gênero no mundo do trabalho, dentro e fora do discurso jurídico trabalhista, se pode significar ganho para o sujeito trabalhador, pode significar também perda de representatividade discursiva da voz desse trabalhador no âmbito institucionalizado da justiça do trabalho.

Na audiência observada, não houve acordo. A audiência transcorreu nos minutos de praxe, tendo a juíza ouvido as testemunhas do reclamante, que responderam a suas perguntas e tiveram igualmente suas falas reformuladas para efeito de registro.

\subsubsection{Efeito monofonizante x efeito polifônico}

Na audiência trabalhista, a figura discursiva do juiz assume posição similar à posição que o sujeito discursivo advogado possui na entrevista inicial, que é a de constituir-se como eixo condutor da formulação dos enunciados.

A diferença fundamental em relação à posição do sujeito advogado diz respeito ao fato de que a centralidade do juiz permeia o processo trabalhista de ponta a ponta, embora apenas 
na audiência sua interferência seja direta, constitutiva do ato de julgar (finalidade do gênero) e do próprio gênero audiência trabalhista.

Esta centralidade nada mais é do que a expressão, em discurso, dos efeitos monofonizantes do discurso jurídico trabalhista, que têm na figura do juiz não só seu eixo argumentativo como a representação do discurso jurídico trabalhista como discurso de poder.

A exemplo do que ocorre na entrevista, instala-se um tipo de assimetria discursiva - e, no caso, triangular (como vimos) - segundo o qual reclamante e reclamada (e respectivos advogados e testemunhas) posicionam-se nos vértices inferiores do triângulo e o juiz no vértice superior. Esta assimetria já é em si marca de polifonia, que nos conduzirá a marcas polifônicas mais sutis. Tais marcas mais sutis são reveladoras de interdiscursos e atestam, para efeito deste trabalho, a tensão entre efeitos monofonizantes e efeitos polifônicos no gênero em pauta.

Vamos considerar as falas da juíza e as falas do reclamante formuladas como resposta às primeiras:
Falas da juíza $\left(\mathrm{L3}^{49}\right)$ :
Falas-resposta do reclamante (L2):
Como anotava seus horários de saída Tinha que anotar de um certo jeito, não era no livro de ponto? pra pôr o horário mesmo...
Recebia orientação para isso?
Bem, tinha que ser assim, era como
mandavam, o gerente, sabe?

\footnotetext{
${ }^{49}$ Mantivemos na análise discursiva de todo o processo trabalhista selecionado as denominações L1, L2 e L3 para referenciar respectivamente o sujeito advogado, o sujeito trabalhador e o sujeito juiz.
} 
$\mathrm{O}$ ato de perguntar proferido pela juíza abre o discurso para a voz do OUTRO, para a polifonia. Embora as perguntas da juíza sejam baseadas no texto da petição, o ato de enunciá-las diretamente ao trabalhador (que, como vimos, representa - enquanto sujeito do mundo do trabalho - aquilo que é externo ao discurso jurídico) areja o discurso e antecipa o novo que virá através da resposta a ser enunciada.

As duas respostas proferidas por L2 atestam um dever, uma obrigação do trabalhador que, enquanto sujeito do mundo do trabalho atuante em uma instituição hierarquizada, deve cumprir determinações superiores, em geral não questionáveis, e que podem não ter nada a ver com o saber especializado do trabalhador, mas sim com normas e procedimentos no âmbito organizacional e/ou legal, como é o caso aqui. As marcas lingüísticas que atestam este "dever fazer" são: "tinha que” e "não era pra pôr", e que apontam na fala do sujeito trabalhador para um novo enunciador: E5(L2). E5 é a voz da instituição manifesta na fala do trabalhador, que aponta para o discurso institucional representativo da organização empregadora, ou discurso empresarial.

Este “dever fazer” orientado pela instituição ocorre através da voz de um sujeito discursivo que ocupa o lugar do que podemos chamar de voz da chefia, ou enunciador E6(L2), que é a voz que assume para si a responsabilidade imediata pelo "como fazer" o que "se deve fazer”. Esta voz está marcada lingüisticamente pelas formas adverbiais “certo jeito”, "mesmo", “assim”; pelo verbo mandar com sujeito indeterminado (“mandavam”), remetendo simultaneamente à figura discursiva da instituição e à figura do sujeito que realiza a intermediação empresa x empregado, ou seja, o “chefe”, e apontando assim para a imbricação dessas figuras discursivas; e o lexema com determinante “o gerente”, evidenciando no plano do discurso a atribuição de “chefe” a um único sujeito.

Esta especificação, enunciada imediatamente após a forma indeterminada, suscita um efeito de sentido muitíssimo interessante. Ao centrar a responsabilidade pelas determinações no sujeito “chefe”, o enunciado coloca em segundo plano a responsabilidade institucional, o que é de certa forma a mostra discursiva de um fato bastante conhecido no mundo do trabalho em nosso país: é rara a percepção de que não são pessoas isoladas (chefias 
específicas) a fonte das determinações superiores. Tais pessoas não são donas absolutas de seu dizer, mas quando o empregado assim as representa em discurso provoca um efeito de apagamento de E5, ou seja, constrói uma cenografia que nubla a percepção da cena genérica e da complexidade das relações na cena da enunciação.

Com o marcador discursivo "bem” no início do segundo enunciado (à primeira vista mera marca de oralidade), o locutor reforça a tensão entre E5 e E6. "Bem”, neste cotexto, engendra na superfície discursiva certo tom de hesitação que nos leva a poder falar em um enunciador E7(L2), que pode ser descrito como a voz que aponta para a tensão E5 X E6. Podemos dizer que a própria estrutura truncada do enunciado (que por um lado é apenas marca de oralidade) é também marca da hesitação que configura a presença de E3.

Finalmente, a expressão fática “sabe?”, ao final do mesmo enunciado (também à primeira vista apenas marca de oralidade), suscita nova voz - E8(L2), que pode ser descrita como a tentativa do sujeito discursivo trabalhador de se inserir no discurso jurídico trabalhista, buscando compartilhar seu saber com o da juíza.

Assim, neste movimento de abertura à polifonia, na audiência trabalhista, destacam-se na fala do sujeito discursivo trabalhador (L2) as seguintes vozes:

E5(L2) $\rightarrow$ Voz da instituição manifesta na fala do trabalhador, que aponta para o discurso institucional representativo da organização empregadora, ou discurso empresarial.

E6(L2) $\rightarrow$ Voz que assume para si a responsabilidade imediata pelo "como fazer" o que “se deve fazer”, remetendo simultaneamente à figura discursiva da instituição e à figura do sujeito que realiza a intermediação empresa x empregado.

Dito de outro modo, aponta para a imbricação dessas figuras discursivas.

E7(L2) $\rightarrow$ Voz que aponta para a tensão E5 X E6.

E8(L2) $\rightarrow$ Voz que revela a tentativa do sujeito discursivo trabalhador de se inserir no discurso jurídico trabalhista. 
Agora vamos considerar as falas do dito reclamante (sujeito trabalhador) e sua reformulação, já mencionadas neste item:

Falas do reclamante (L2):

Tinha que anotar de um certo jeito, não era pra pôr o horário mesmo...

Bem, tinha que ser assim, era como mandavam, o gerente, sabe?
Reformulação (L3):

O reclamante anotava incorretamente o horário de saída

A determinação vinha da gerência

Observe-se que o primeiro procedimento de reformulação de L3 é desfazer a estrutura oral, em si mais arejada e impregnada pela subjetividade. Os enunciados são organizados na ordem SVO (sujeito-verbo-objeto e/ou complementos), própria ao texto escrito e à norma padrão. Todas as vozes enunciadas nas falas originais são cortadas. Vejamos como:

O discurso institucional representativo da organização empregadora, ou discurso empresarial - E5(L2), é apagado eliminando-se as expressões da ordem do “dever fazer”. O marcador discursivo "incorretamente" transfere a responsabilidade pela forma de registro no livro de ponto integralmente ao sujeito trabalhador.

O “como fazer”, que nos remete a E6(L2), surge na fala da juíza de modo não ambíguo. Não há imbricação entre os discursos de poder na empresa e o discurso da chefia (que se assujeita ao primeiro), tornando-se este último a fonte dos procedimentos a serem cumpridos. Por não haver a explicitação dos dois discursos, não há tensão explicitada: portanto, apaga-se E7(L2). Pode-se dizer que na segunda fala de L3 no quadro acima, o lexema "gerência" guarda vestígios da tensão, daí podermos falar em um eventual E1(L3), que pode ser descrito como a voz autorizada do discurso jurídico trabalhista que reconhece a tensão, mesmo que de forma ligeira. 
Evidentemente, E8(L2) também é apagado, restando em registro oficial uma fala reveladora apenas de uma parcela muita pequena do que foi dito de fato pelo sujeito trabalhador. A reformulação, que se dá de acordo com os processos de retextualização já explicados, realiza uma espécie de paráfrase sintética, cujos elementos necessariamente excluídos o são por determinações genéricas. A reformulação da juíza é assim o principal procedimento lingüístico-discursivo de monofonização do gênero audiência trabalhista. Podemos chamar de E2(L3) a voz que melhor caracteriza L3 como voz homogeneizadora.

Assim, às vozes relacionadas acima referentes a L2, adicionemos as seguintes, referentes a L3:

E1(L3) $\rightarrow$ Voz autorizada do discurso jurídico trabalhista que reconhece as tensões do mundo do trabalho, mesmo que de forma ligeira.

E2(L3) $\rightarrow$ A voz que melhor caracteriza L3 como voz homogeneizadora, e que identifica o discurso jurídico trabalhista como discurso de poder.

\subsubsection{Níveis de representatividade}

Graças aos efeitos polifônicos $\mathrm{x}$ efeitos monofonizantes descritos acima, podemos apreender cinco importantes níveis de representatividade do sujeito trabalhador no gênero em questão. São posições de sujeito distintas, mas complementares:

1. O sujeito trabalhador como cidadão comum, inserido no mundo do trabalho, mas alheio às peculiaridades do discurso jurídico trabalhista que lhe diz respeito. É o sujeito que hesita, que trunca os enunciados.

2. O sujeito trabalhador que se insere na esfera jurídico trabalhista, buscando, via interlocução, a partilha de saberes. É o sujeito que diz: “sabe?”.

3. O sujeito trabalhador que possui um saber especializado, mas que não recobre necessariamente o conhecimento dos procedimentos de seu dia-a-dia que dialogam com saberes de outras áreas, como normas e procedimentos gerais da organização e procedimentos legais aplicados no trabalho. 
4. O sujeito trabalhador que reconhece a tensão discurso institucional $\mathrm{x}$ discurso da chefia.

5. O sujeito trabalhador que sabe, enfim, que não pode inserir-se plenamente na esfera jurídica trabalhista e reconhece no juiz o depositário de sua palavra.

\subsubsection{Interdiscursos}

Os cinco níveis de representatividade de L2 na audiência trabalhista analisada caracterizam respectivamente cinco interdiscursos que se interconstituem. Estes interdiscursos são os locais de onde fala o sujeito trabalhador e que determinam as posições discursivas descritas acima. Tanto os níveis de representatividade como os interdiscursos podem variar em função da causa específica que move o processo trabalhista e em função do perfil dos interlocutores centrais (trabalhador, advogado e juiz). Temos assim, no que se refere a L2:

- O interdiscurso do sujeito trabalhador como cidadão comum, inserido no mundo do trabalho, mas alheio às peculiaridades do discurso jurídico trabalhista que lhe diz respeito.

- O interdiscurso do sujeito trabalhador que se insere na esfera jurídico trabalhista, buscando, via interlocução, a partilha de saberes.

- O interdiscurso do sujeito trabalhador que possui um saber especializado, mas que não recobre necessariamente o conhecimento dos procedimentos de seu dia-a-dia que dialogam com saberes de outras áreas, como normas e procedimentos gerais da organização e procedimentos legais aplicados no trabalho.

- O interdiscurso do sujeito trabalhador que reconhece a tensão discurso institucional $\mathrm{x}$ discurso da chefia.

- O interdiscurso do sujeito trabalhador que sabe, enfim, que não pode inserir-se plenamente na esfera jurídica trabalhista e reconhece no juiz o depositário de sua palavra. 
Embora não tenhamos o registro gravado de todas as falas proferidas pelo sujeito trabalhador na audiência observada, podemos assegurar que em sua grande totalidade obedecem ao mesmo padrão constatado nesta análise, sem desvios, devido à forte institucionalização do gênero.

Pode-se assim resumidamente afirmar que, com base nesta análise de fragmento de texto pertencente ao gênero audiência trabalhista:

- $\quad$ L3, por coerção genérica, constrói o texto suprimindo a fala de L2.

- Esta supressão se dá via reformulação da voz do trabalhador (o juiz é a figura autorizada a falar pelo trabalhador), estritamente de acordo com as coerções do gênero.

- As falas de L3 e L2 (as de L3 em proporção bem menor) não são homogêneas. A polifonia traz à tona níveis de representatividade distintos.

O fragmento analisado da audiência trabalhista observada pode ajudar a mostrar que, a exemplo do que acontece na entrevista inicial, a fala do trabalhador encontra - em certa medida - algum espaço de manifestação durante a realização da audiência, embora só possa formular, modular e refazer sua fala mediante solicitação expressa do juiz. No entanto, tal manifestação no tempo do acontecimento não tem valor legal: tem-no somente as falas do trabalhador reformuladas pelo sujeito discursivo juiz (que realiza procedimento lingüísticodiscursivo muito próximo ao realizado pelo sujeito discursivo advogado para redação da petição).

A audiência trabalhista parece-nos constituir-se em gênero que traz imbricados os dois anteriores (entrevista e petição) no que se refere aos efeitos de monofonização e polifonia. A audiência possui a abertura discursiva que caracteriza a entrevista e também e concomitantemente o fechamento discursivo que caracteriza a petição. 
5.6 Retextualização, intertexto e interdiscurso: o diálogo entre Eu e Outro

Pode-se dizer que a voz do trabalhador se materializa/gramaticaliza de, ao menos, três diferentes formas durante a produção textual do processo trabalhista: diretamente como primeira pessoa do discurso no texto da entrevista, indiretamente como terceira pessoa no texto da petição e diretamente como primeira pessoa do discurso na audiência, mas via intermediação da voz do juiz.

No processo de retextualização da entrevista à petição, o EU sofre apagamento, pois, do primeiro ao segundo gênero, o EU passa a caracterizar-se como OUTRO. Mas o apagamento não é completo, se considerarmos (como é o caso nesta pesquisa) o pressuposto da primazia da interdiscursividade. Desta perspectiva, o que ocorre é uma recategorização do EU, que passa a inscrever-se no discurso jurídico trabalhista de acordo com as restrições próprias a este discurso e aos gêneros por ele instituídos.

A voz do trabalhador caracteriza-se, no seu caminhar da entrevista à petição, por apresentar ao menos dois diferentes níveis de intertextualidade com seu OUTRO. Tais níveis de intertextualidade atestam a polifonia, presente na entrevista e na petição (apesar do forte caráter monofonizante deste último gênero), e a rica interdiscursividade do processo de produção do discurso jurídico trabalhista.

O primeiro nível, presente na entrevista, caracteriza-se por certo tipo de relação EU X OUTRO em que:

- EU se expressa em primeira pessoa e é sujeito de sua fala.

- O OUTRO igualmente se expressa em primeira pessoa e é sujeito de sua fala.

- O OUTRO conduz a conversação e imprime a direção argumentativa.

No segundo nível, por sua vez:

- O OUTRO absorve a fala do EU e fala por ele. 
- EU passa a constituir-se como pessoa de referência.

- O OUTRO conduz a conversação e imprime a direção argumentativa.

Nos dois níveis, EU e OUTRO se retroalimentam enquanto co-construtores do discurso. Assim, EU e OUTRO se pressupõem e se revestem de diferentes modos de dizer que podem ser categorizados como níveis de representatividade. Da mesma forma, cada um desses níveis, expressos nos diferentes gêneros, apresenta um modo de coesão intratextual, que nada mais é do que a maneira como o texto constrói as representações desses níveis, ou suas cenografias.

Especificamente no que se refere à petição trabalhista, podemos dizer que, de uma dialogicidade aberta na entrevista inicial, as vozes do discurso passam a construir-se, na petição, através de apagamento da explicitude do diálogo, o que pôde ser verificado pela análise das especificidades dos gêneros em que tais vozes se constituem (entrevista e petição trabalhista) - e que são ditadas, em última análise, pela própria função social de tais gêneros.

Partindo-se da perspectiva da semântica global, para a qual a interdiscursividade é anterior à própria discursividade, não se pode admitir a ausência de diálogo constitutivo entre o EU e o OUTRO no discurso, mas apenas o mascaramento dessa dialogicidade, que é o que ocorre na petição trabalhista.

A análise dos processos de referenciação que transfiguram EU em OUTRO (que podem ser considerados como processo de gramaticalização que materializa no texto a direção argumentativa que veio sendo construída em discurso) mostra não apenas como esse EU é constituído pelo OUTRO, mas também como este OUTRO, ao apropriar-se desse EU, não o elimina, apenas o mascara de acordo com a competência discursiva do locutoradvogado que o impele a categorizar o eu-trabalhador de forma a ser apreensível no discurso jurídico trabalhista. Esta apreensão deve se dar de uma certa maneira, coerente com o paradigma do discurso jurídico, em particular do discurso jurídico trabalhista. 
Observe-se que o interlocutor final de todo o processo trabalhista será o juiz do trabalho, representante empírico e discursivo do poder instituído, imbuído necessariamente de todas as contradições próprias ao direito trabalhista. A este leitor último caberá uma decisão que só poderá ser tomada se todos os elementos discursivos a serem interpretados puderem ser interpretados dentro do que é paradigmático no discurso jurídico trabalhista. Se a visão convencional que este Direito tem do trabalhador é "x", é como " $\mathrm{x}$ ” que deverá aparecer no discurso. Portanto, referentes como "reclamante”, “recorrente”, "solicitante", ao corresponderem ao paradigma a ser acionado, se por um lado configuram um mascaramento interdiscursivo entre Eu-trabalhador e Outro-locutoradvogado, por outro, possibilitam o estabelecimento de um novo nível interdiscursivo entre tais sujeitos e um OUTRO privilegiado, que é a figura empírica e discursiva do juiz do trabalho.

Na audiência pode-se observar o terceiro nível de representatividade discursiva do sujeito trabalhador, que se caracteriza por certo tipo de relação EU X OUTRO em que:

- EU se expressa em primeira pessoa e é sujeito de sua fala apenas de modo parcial, pois esta só tem valor legal após ser submetida à reformulação do juiz (o OUTRO).

- O OUTRO igualmente se expressa em primeira pessoa, é sujeito de sua fala e sujeito institucional de todas as falas proferidas em audiência, uma vez que todas são submetidas à sua reformulação.

- O OUTRO conduz a conversação e imprime a direção argumentativa. 


\subsection{A voz do trabalhador na cena enunciativa}

O desenrolar do processo jurídico trabalhista é, como foi visto, eminentemente uma prática discursiva que instaura uma determinada cena enunciativa. Como prática discursiva, pressupõe locutores que assumem níveis de representatividade distintos nesse desenrolar. Os níveis de representatividade do sujeito trabalhador - locutor que nos interessa nesta tese - variam de acordo com as etapas do processo na direção argumentativa almejada, a saber: a busca da obtenção do ganho de causa. Embora a direção argumentativa, como é o seu papel, esteja na base desta prática, sustentando-a, ela avança de forma heterogênea, interdiscursiva. A representatividade do sujeito trabalhador em discurso não é, portanto, estanque, nem tão pouco homogênea.

O processo trabalhista, assim compreendido, transcorre num tempo que é ao mesmo tempo processual e linear, constituindo-se como prática complexa que abrange vários níveis de interdiscursividade e representatividade do sujeito trabalhador, relacionados entre si.

Esta prática discursiva dá-se mediante certas condições de produção de discurso, que correspondem à descrição dos sujeitos envolvidos e suas respectivas formações discursivas. Tais formações não são homogêneas e pertencem a campos discursivos distintos que compõem o grande pano de fundo da cena enunciativa, ou seja, compõem a cena englobante do discurso jurídico trabalhista. Os principais campos discursivos que dialogam no processo pertencem à esfera jurídico-trabalhista e à esfera do trabalho. São igualmente heterogêneos, atravessados por diferentes formações, cuja expressão lingüística se faz presente na materialidade dos gêneros utilizados no discurso jurídico trabalhista. A apreensão das marcas lingüísticas em cada gênero torna possível o reconhecimento dos diferentes interdiscursos e níveis de representatividade do sujeito trabalhador, foco desta tese.

Os gêneros que constituem e dão existência material à prática discursiva jurídico-trabalhista formam o que se chama cena genérica. Os gêneros do discurso da prática jurídica são altamente institucionalizados e são o recurso material que orienta o dizer. Como vimos na análise, os gêneros oscilam entre si no que se refere à abertura para a polifonia e para o OUTRO. Esta oscilação é outro fator importante que permite observar os níveis de 
representatividade distintos que o sujeito trabalhador assume nos diferentes gêneros e a que interdiscursos tais níveis remetem.

No desenrolar do processo, o sujeito discursivo trabalhador é construído como sujeito com baixa margem de ação efetiva enquanto sujeito que se autodesigna EU. Atravessado pelos discursos do mundo do trabalho e alheio ao saber especializado do mundo jurídico, a cenografia construída em cada gênero revela um sujeito deslocado, imbuído da contradição de ser menos sujeito e mais objeto em uma prática discursiva que, em tese, lhe diz respeito diretamente.

Vejamos a síntese das relações esboçadas até aqui, no que se refere à representatividade discursiva da voz do trabalhador, chamado de L2: 


\section{Enunciadores de L2:}

Na entrevista, L2 apresenta-se polifonicamente como:

$\mathrm{E} 1(\mathrm{~L} 2) \rightarrow$ voz discursiva que revela desconhecimento das sutilezas da esfera jurídico trabalhista.

$\mathrm{E} 2(\mathrm{~L} 2) \rightarrow$ voz discursiva que revela um sujeito trabalhador mais inserido nessa esfera.

E3(L2) $\rightarrow$ voz discursiva que revela um sujeito trabalhador satisfeito ao ver-se inserido nessa esfera e perceber-se beneficiado por ela.

Na petição, L2 apresenta-se polifonicamente como:

E4 (L2) $\rightarrow$ voz que revela um sujeito discursivo posto à margem da interlocução, excluído do eixo dialógico EU X TU, e referido como ELE (requerente ou reclamante, e não como trabalhador).

Na audiência, L2 apresenta-se polifonicamente como:

E5(L2) $\rightarrow$ Voz da instituição manifesta na fala do trabalhador, que aponta para o discurso institucional representativo da organização empregadora, ou discurso empresarial.

E6(L2) $\rightarrow$ Voz que assume para si a responsabilidade imediata pelo "como fazer" o que "se deve fazer", remetendo simultaneamente à figura discursiva da instituição e à figura do sujeito que realiza a intermediação empresa $\mathrm{x}$ empregado. Dito de outro modo, aponta para a imbricação dessas figuras discursivas.

E7(L2) $\rightarrow$ Voz que aponta para a tensão E5 X E6.

E8(L2) $\rightarrow$ Voz que revela a tentativa do sujeito discursivo trabalhador de se inserir no discurso jurídico trabalhista. 
Níveis de representatividade de L2:

\section{Na entrevista:}

1. O sujeito trabalhador visto como cidadão comum, inserido no mundo do trabalho, mas alheio às peculiaridades do discurso jurídico trabalhista que lhe diz respeito. É o sujeito que diz: "Hã?”.

2. O sujeito trabalhador que se insere na esfera jurídico trabalhista, aprende na interlocução e pode reconstruir sua fala. É o sujeito que diz : “Ah!...tá”.

3. O sujeito trabalhador que se insere na esfera em pauta e satisfaz-se ao sentir-se beneficiado por ela. É o sujeito que ri: “Ha! Há!”.

\section{Na petição:}

1. Nível que atesta a posição de sujeito apagado e excluído da interlocução direta.

Refere-se a E4(L2), posição discursiva autorizada por L2, que projeta sua fala na voz de L1. Ao autorizar L1 a falar por ele, L2 consolida sua posição de sujeito discursivo alheio à esfera jurídico trabalhista.

\section{Na audiência:}

1. O sujeito trabalhador como cidadão comum, inserido no mundo do trabalho, mas alheio às peculiaridades do discurso jurídico trabalhista que lhe diz respeito. É o sujeito que hesita, que trunca os enunciados.

2. O sujeito trabalhador que se insere na esfera jurídico trabalhista, buscando, via interlocução, a partilha de saberes. É o sujeito que diz: “sabe?”.

3. O sujeito trabalhador que possui um saber especializado, mas que não recobre necessariamente o conhecimento dos procedimentos de seu dia-a-dia que dialogam com saberes de outras áreas, como normas e procedimentos gerais da organização e procedimentos legais aplicados no trabalho.

4. O sujeito trabalhador que reconhece a tensão discurso institucional $\mathrm{x}$ discurso da chefia.

5. O sujeito trabalhador que sabe, enfim, que não pode inserir-se plenamente na esfera jurídica trabalhista e reconhece no juiz o depositário de sua palavra. 
Interdiscursos de que se constitui a fala de L2:

\section{Na entrevista:}

- O interdiscurso do cidadão comum, inserido no mundo do trabalho, mas alheio às peculiaridades do discurso jurídico trabalhista que lhe diz respeito.

- O interdiscurso do sujeito trabalhador que se insere na esfera jurídico trabalhista, aprende na interlocução e pode reconstruir sua fala.

- O interdiscurso do sujeito trabalhador que se insere na esfera em pauta e satisfaz-se ao sentir-se beneficiado por ela.

\section{Na petição:}

- O interdiscurso do sujeito posto à margem da interlocução direta no discurso jurídico trabalhista, excluído do eixo dialógico EU X TU, e referido como ELE (requerente ou reclamante, e não como trabalhador).

\section{Na audiência:}

- O interdiscurso do sujeito trabalhador como cidadão comum, inserido no mundo do trabalho, mas alheio às peculiaridades do discurso jurídico trabalhista que lhe diz respeito.

- O interdiscurso do sujeito trabalhador que se insere na esfera jurídico trabalhista, buscando, via interlocução, a partilha de saberes.

- O interdiscurso do sujeito trabalhador que possui um saber especializado, mas que não recobre necessariamente o conhecimento dos procedimentos de seu dia-a-dia que dialogam com saberes de outras áreas, como normas e procedimentos gerais da organização e procedimentos legais aplicados no trabalho.

- O interdiscurso do sujeito trabalhador que reconhece a tensão discurso institucional $\mathrm{x}$ discurso da chefia.

- O interdiscurso do sujeito trabalhador que sabe, enfim, que não pode inserir-se plenamente na esfera jurídica trabalhista e reconhece no juiz o depositário de sua palavra. 


\subsubsection{Direção argumentativa geral}

A representatividade da voz do sujeito trabalhador assim construída possui, como já foi dito, uma direção argumentativa geral e bem definida, embora não linear, mas sim entremeada de recuos e avanços dessa voz. Tais recuos e avanços são perceptíveis pelos efeitos monofonizantes e efeitos polifônicos dos diferentes gêneros estudados, efeitos tais capturados através da análise da materialidade lingüística dos textos. Esta direção argumentativa geral, que está na base mesma do discurso jurídico trabalhista e é apreensível/construída nos gêneros que compõem o processo, pode ser traduzida como a luta pelo ganho da causa instaurada pelo trabalhador, construída oficial e legalmente na petição trabalhista pelo locutor-advogado a partir de seu conhecimento especializado e a partir da entrevista com o trabalhador. A cenografia própria ao gênero petição desloca o sujeito trabalhador da interlocução direta com o juiz, categorizando-o como o ELE sobre cuja causa se delibera. Esta posição discursiva é predominante em toda a cena enunciativa e é responsável pelos efeitos monofonizantes e pela polifonia que nos permitem considerar a direção argumentativa geral não linear e não homogênea, tendo como elementos constitutivos e desestabilizantes os interdiscursos do mundo do trabalho.

Os efeitos monofonizantes do discurso jurídico trabalhista, que promovem o deslocamento do sujeito trabalhador, estão expressos na voz desse sujeito por E3(L2) e E4(L2). Os demais enunciadores de L2 apontam para níveis de representatividade do sujeito que atestam sua pertença ao mundo do trabalho de modo amplo e apontam para alguns interdiscursos constitutivos desse mundo, revelados pela polifonia do discurso jurídico trabalhista. Na fala do sujeito trabalhador, as vozes que têm esse papel são E1(L2), E2(L2) e E8(L2), que apontam para o sujeito trabalhador como, primeiramente, sujeito do mundo e, secundariamente, como sujeito do mundo do trabalho; e E5(L2), E6(L2) e E7(L2), que apontam, na fala de L2, para a esfera empregadora, a partir da figura das chefias e representantes da hierarquia empresarial, assim como para suas ações como atores sociais no âmbito da empresa, que não se representam quando atuam, mas à empresa a quem servem. 


\subsubsection{Recuos e avanços da direção argumentativa na petição trabalhista}

Como enunciadores de L2, E1, E2 e E8 funcionam como vozes que provocam um recuo na direção argumentativa geral, uma vez que são vozes que se distanciam do saber jurídico especializado, capaz de estabelecer formalmente a interlocução com o juiz, remetendo a saberes do mundo do trabalho.

E5, E6 e E7 provocam simultaneamente um recuo - por não constituírem saber jurídico especializado - e um avanço - uma vez que trazem para o discurso jurídico trabalhista pontos de vista do discurso empresarial, com o qual o saber jurídico dialoga e dos quais se apropria através dos processos de retextualização realizados pelo juiz com o objetivo de buscar "a verdade dos fatos".

E3 e E4 provocam o sentido de deslocamento do sujeito trabalhador, que aceita delegar sua voz ao locutor-advogado. Estes pontos de vista se alinham à direção argumentativa geral, que se constrói com base nesse mesmo deslocamento.

A petição trabalhista, o mais homogêneo dos gêneros estudados, situa-se como gênero central no processo justamente por fazer prevalecer E4. Portanto, é ao redor da marca lingüística lexical "requerente" e similares, que referem e constroem E4, que se articula o gênero petição trabalhista. Frisamos que, embora considerado o gênero mais homogêneo, nem por isso deixa de constituir-se das vozes dos seus Outros, como já foi visto, observando-se na própria utilização do lexema "referente" e correlatos os primeiros indícios de alteridade.

Sendo o gênero mais homogêneo, poder-se-ia esperar nele uma direção argumentativa mais linear, que levasse à aceitação do pedido pelo juiz sem maiores percalços cenográficos. Observamos, no entanto, que não é o que ocorre. Ao fazermos uma leitura atenta das quatro petições analisadas neste trabalho (cujos textos completos estão nos Anexos B e C), pudemos perceber um interessante movimento de avanço e recuo argumentativo durante a 
construção da cenografia, movimento este que pode ser compreendido também como a descrição das estratégias de articulação do plano semântico modo de coesão, considerado por nós o eixo construtor da cenografia (ver item 2.2.1 - Semântica global e pragmática). Tal descrição deve ser entendida, evidentemente, mais como a descrição dos modos de entrelaçamento do modo de coesão com os demais planos semânticos - e dos planos em conjunto com as respectivas cenas genérica e englobante - e menos como simples enumeração das estratégias coesivas. Observemos tais entrelaçamentos através da análise dos modos de coesão na Petição inicial para pedido de hora-extra (Anexo B).

No primeiro parágrafo, instala-se, como já foi visto, a estratégia de referenciar o sujeito trabalhador em terceira pessoa. A referência ao nome do trabalhador e os verbos em terceira pessoa são a materialização lingüística deste distanciamento. Tais estratégias estruturam a dêixis enunciativa no que tange à pessoa, estabelecendo um ELE no lugar do que seria um EU. Conseqüentemente, tais estratégias estabelecem um modo de ser em discurso específico deste co-enunicador, e que corresponde à construção do plano semântico “modo de enunciação” de uma maneira peculiar à petição: o sujeito trabalhador apresenta-se como enunciando sem enunciar diretamente. Daí ser possível apreender um certo tipo de corporalidade/personalidade deste sujeito, via materialidade lingüística, que o caracteriza como trabalhador deslocado do processo interlocutivo. Importa ainda verificar que tais escolhas (que, num primeiro momento, referem-se à articulação da dêixis e do modo de enunciação) são a estratégia coesiva central, construindo o plano semântico modo de coesão de maneira a levar o texto numa certa direção. Estas estratégias criam um recuo na direção argumentativa, pois remetem aos interdiscursos do mundo do trabalho. Importa frisar que tal recuo estratégico alimenta os avanços na direção argumentativa, pois sem a interdiscursividade constitutiva com o mundo do trabalho não haveria discurso jurídico trabalhista.

No mesmo parágrafo, a presença do jargão latino “ut”, que significa “conforme” em linguagem jurídica, cumpre a função de avançar no mundo do propriamente jurídico, como conector argumentativo altamente especializado, ajudando a estabelecer um modo de coesão próprio a tal discurso. 
Em praticamente todos os parágrafos seguintes, até o final do texto, o lexema "reclamante" aparece ao menos uma vez. O lexema funciona coesivamente garantindo, por todo o texto, o recuo argumentativo que atesta a interdiscursividade com o mundo do trabalho.

O segundo parágrafo estabelece recuo que remete ao sujeito trabalhador também como sujeito do mundo: ele é "pobre”. A partir daí utilizam-se os conectores argumentativos “portanto” (pressuposto em "não estando em condições de demandar...”), que aponta para o interdiscurso do mundo da vida, e "motivo pelo qual” (em "motivo pelo qual requer que essa I. Vara lhe conceda os benefícios da JUSTIÇA GRATUITA...”), que aponta para o discurso jurídico, estabelecendo, num único movimento discursivo, o recuo e o avanço necessários à direção argumentativa geral.

Nos oitavo e nono parágrafos nota-se o mesmo movimento:

No exercício da função de Caixa, subordinava-se à jornada contratual de 6 (seis) horas diárias, com início às 07h00 e término Pás 13 h00 [...].

Fato é que o reclamante iniciava seu expediente em média às 06h00 e encerrava-o às 14h00. Todavia, por exigência do Banco-reclamado, lhe era obrigado a assinalar em folha de freqüência o horário contratual [...].

A expressão “fato é que” é usada para operar argumentativamente apontando para a discrepância constatada entre o horário contratual (assinalado no parágrafo anterior) e o real. A seguir, o operador "todavia” aponta o motivo da discrepância. A coesão lingüística entre parágrafos e orações realizada através de tais operadores faz mais do que encadear os segmentos coerentemente. Ela assinala os interdiscursos em confronto e faz recuar a direção argumentativa para os interdiscursos do mundo do trabalho, deles apropriando-se para avançar pelo jurídico.

A comparação talvez seja por demais simples, mas vale a pena esboçá-la para que se garanta a compreensão destes recuos: ao recuar, a argumentação lingüística atua como o esportista que pratica salto à distância. Assim como este precisa distanciar-se bem para saltar o mais longe possível, aquela recorre aos interdiscursos para projetar-se adiante com 
sucesso. Operadores argumentativos em sentido estrito, e demais marcas lingüísticas que operam como tais, fazem na superfície discursiva as devidas amarrações que, ao mesmo tempo, dão coerência ao texto e evidenciam a interdiscursividade.

O décimo parágrafo repete a estratégia, através do uso do operador "inobstante”. No décimo primeiro, explicita-se o pedido ao juiz, construído através dos movimentos discursivos descritos.

Os parágrafos 13 e 14 estabelecem novo recuo argumentativo, agora na direção da obtenção da isenção de recolhimentos fiscais e previdenciários. Inicialmente, o locutor aponta para o caráter alimentar do salário, apoiado em menção de lei, avançando no campo jurídico. A seguir, o operador “daí...que”, utilizado de modo muito feliz para tornar inevitável a aceitação plena do que se dirá, conduz invariavelmente à compreensão de que a causa possui caráter indenizatório, estando portanto isenta de recolhimentos de qualquer tipo. “Daí... que” pertence ao grupo de operadores que constroem o sentido de "é necessário admitir o outro”, como pois que, já que, visto que, etc. (cf. Ducrot, 1981).

A argumentação avança até o décimo sexto parágrafo, no qual o operador "por conseqüência” estende a não aplicação de recolhimentos também no que se refere a imposto de renda. Nestes parágrafos, o recuo dá-se através do interdiscurso do mundo da vida, daquele interdiscurso que remete à figura do sujeito trabalhador como pessoa do mundo. A argumentação salta facilmente para o mundo jurídico, realizando o avanço necessário, através da menção da legislação, apresentada como inquestionável a partir do próprio operador argumentativo selecionado.

No décimo sétimo parágrafo, explicita-se a possibilidade de uma negativa do pedido de não recolhimento por parte do juiz, contra o que imediatamente interpõe-se a ameaça de uma nova ação trabalhista por perdas e danos. O operador “na eventualidade de”, escolhido em lugar de "se" (que, como operador condicional, ressaltaria a ameaça, o que não convém), funciona metadiscursivamente ao apontar para o próprio discurso jurídico trabalhista como via de acesso do trabalhador aos seus direitos. 
O uso de "portanto” abrindo o décimo nono parágrafo leva a um efeito de sentido próximo a “daí que”, levando à impossibilidade de não se admitir o outro, ou, neste caso, do que está por se dizer. Uso diferente de "portanto" foi feito no parágrafo anterior, em que a dedução sob forma de conclusão apenas explicita o que já está dito.

De fundamental destacar que o Banco-reclamado efetua a paga dos salários de seus milhares de funcionários ativos e inativos no dia 20 de cada mês, portanto dentro do próprio mês de competência.

Portanto, não se utilizando o Banco-reclamado da faculdade prevista no artigo 459, $\S 1^{\circ}$. da C.L.T. ${ }^{50}$, para a paga normal dos salários de seus funcionários, não poderá esse se favorecer desse instituto [...].

O recuo ao interdiscurso empresarial, entrelaçado ao interdiscurso jurídico trabalhista pelo operador "portanto" em acepções distintas, garante, mais uma vez, a direção argumentativa geral em meio ao campo do especificamente jurídico.

No vigésimo parágrafo, a estratégia continua através do uso de "e ainda". A seguir, apresenta-se no vigésimo primeiro parágrafo o pedido específico (correção monetária dos valores requeridos com base no pagamento no dia 20), introduzido pelo operador “destarte”, de função equivalente a de “portanto”, utilizado no primeiro parágrafo da citação anterior. "Portanto", nesta acepção, garante que se evidencie o que já foi evidenciado.

O vigésimo segundo parágrafo apresenta um movimento discursivo peculiar ao apresentar o operador "ou” como introdutor de uma fala de L1 (locutor-advogado) ao empregador, seu interlocutor indireto (a interlocução se faz via juiz). Esta fala se apresenta como uma decisão alternativa proposta ao reclamado. Este conector não traduz simplesmente um efeito de alternância, mas coloca em confronto dois interdiscursos que compõem o discurso jurídico trabalhista hoje no Brasil: o interdiscurso que garante os direitos do trabalhador

\footnotetext{
50 Artigo que permite às organizações efetuarem o pagamento dos salários até o quinto dia útil do mês seguinte ao mês trabalhado.

51 Interessante observar como os conectivos que a gramática normativa convencionou denominar de coordenativos têm, de fato, valor argumentativo e podem funcionar como operadores que constroem sentido novo e a própria direção argumentativa, se se tiver em mente uma concepção interdiscursiva de linguagem.
} 
através do julgamento com base nas argumentações das partes e o interdiscurso que propõe o encurtamento desse caminho através da conciliação. Vejamos o parágrafo na íntegra:

Ante o exposto, é a presente Reclamação Trabalhista proposta com fundamento nos artigos 837 e 842 da Consolidação das Leis do Trabalho, para que se digne Vossa Excelência determinar as notificações das reclamadas, na pessoa de seus representantes legais, para que, querendo, manifestem-se sobre os termos da presente ação, ou venham conciliarem-se com o reclamante, em audiência de instrução e julgamento a ser designada, sob pena de revelia e confissão quanto a matéria de fato, acompanhando-a até final decisão que deverá julgá-la procedente, condenando as reclamadas aos pagamentos das verbas pleiteadas, acrescidas de juros e correção monetária, custas e demais cominações de estilo.

O operador de síntese "ante o exposto” que abre o parágrafo funciona como elemento lingüístico que certifica a validade da causa e incita a ação do juiz. Este deverá tomar a ação de acionar a parte reclamada (observe-se o uso de "para que”). Ao mesmo tempo, "para que” é utilizado como operador para incitar a ação do empregador, ou reclamado. Ocorre que este poderá “querer” escolher (observe-se a modalização que simula uma possibilidade de escolha mais ampla do que de fato é; e o uso, a seguir, do conector "ou”) entre a manifestação que demandará os esforços argumentativos para efeito de julgamento do juiz; a conciliação em juízo; ou mesmo a omissão (o que se considera "confissão quanto a matéria de fato”). A ação trabalhista consolidada na petição é, portanto, prática discursiva com força de ato que incita os movimentos discursivos das partes envolvidas, que formarão a tríade interlocutiva (empregado-empregador-juiz) na audiência que se seguirá.

De fato, ao construir a direção argumentativa geral em prol do ganho da causa pelo trabalhador, a petição trabalhista constrói inicialmente um movimento discursivo que visa a incitar a ação do juiz e da reclamada. A petição interpela os seus Outros, obrigando-os à prática discursiva jurídica. Os recuos e avanços costurados coesivamente pelos operadores e demais segmentos lingüísticos que assumem função coesiva atestam esta vocação na superfície discursiva.

Como se viu, preferimos falar em interdiscursos para designar a origem construtora dos sentidos costurados pelos operadores argumentativos, em vez de nos referirmos às classes 
argumentativas e aos "topoi", conforme nomenclatura de Ducrot, o que talvez tornasse as relações aqui estabelecidas mais coerentes com a semântica argumentativa. Ocorre que a proposta teórica desta tese ressalta o primado da interdiscursividade. O conceito de interdiscurso aqui utilizado parece recobrir os usos de conceitos como classe argumentativa e "topoi" quando se trata de apontar para a origem discursiva das falas postas em enunciados seqüenciais (textos), e portanto articuladas coesivamente por operadores argumentativos que se compreendem em extensão tão somente através da aceitação da linguagem como interdiscursiva. O conceito de gênero (e modos de genericidade) e o de cena enunciativa (que inclui o conceito de gênero) ajudam a delimitar a abrangência dos interdiscursos, pois os demarcam no universo discursivo em campos específicos, dirigindo a interpretação e a melhor compreensão da força dos operadores argumentativos.

As três petições constantes no Anexo C, e que não fazem parte do processo trabalhista em pauta, articulam-se da mesma maneira. É interessante notar que as três foram redigidas por um advogado diferente daquele que conduziu o processo analisado na íntegra, cuja articulação da direção argumentativa em petição acabamos de observar. Existem diferenças de construção de cenografia de ordem aparentemente apenas estilística, mas que na verdade são constitutivas de certo interdiscurso jurídico trabalhista, ao qual as marcas lingüísticas apontam. Tal interdiscurso é o interdiscurso que garante os direitos do trabalhador através do julgamento com base nas argumentações das partes, que se confronta com 0 interdiscurso que propõe o encurtamento desse caminho através da conciliação, conforme visto acima.

Esta diferença central não abala a direção argumentativa geral, construída nos enunciados e constitutiva do próprio gênero petição trabalhista, mas revela um recuo argumentativo novo, em relação à petição já analisada, que destaca este interdiscurso e as diferenças polêmicas no próprio meio jurídico trabalhista em relação a como conduzir a causa: com mais luta e vigor, com eventualmente mais chances de se obter vantagens, embora durante um tempo de duração do processo mais longo; ou de forma mais concessiva e aberta, com menor chance de se obter o máximo de vantagens, mas em compensação com maior possibilidade de se obterem as vantagens e direitos possíveis no menor espaço de tempo. 
Poderíamos dizer que tais interdiscursos apontam para as duas formações discursivas já mencionadas, que se confrontam no campo jurídico trabalhista, e que são evidenciadas nos dias de hoje pela necessidade de exame e modificação da legislação trabalhista brasileira.

Nos texto 1, o uso da interjeição "ora” como operador argumentativo aponta menos para a indignação de que quer revestir-se o locutor-advogado em seu modo de enunciação, criando para si um certo tipo de corporalidade/personalidade, e mais para a polêmica interdiscursiva instalada. É bem verdade que este confronto só pode ser evidenciado mais claramente comparando-se petições redigidas por diferentes advogados, considerando-se que o "estilo" determina, de fato, a formação discursiva a que se alinha o locutor.

Observe-se que o operador “ora” dirige a argumentação apontando para a polêmica mencionada também porque a petição em que aparece não é petição inicial, mas petição encaminhada posteriormente, que realiza o ato de impugnar decisão do juiz já tomada em função da petição inicial e à juntada da petição, conforme expresso no texto.

Atente-se para o uso de "desde que” no segundo parágrafo do texto 1, e "certo é que”, no terceiro parágrafo, operadores concessivos que obrigam a aceitação do outro segmento da construção. Vejamos os parágrafos 2 a 4:

Tendo sido apresentado em audiência, dia 11.09.98, o documento de fls. 26, o reclamante no final do mesmo dia protocolou diretamente na I. Secretaria da Junta petição através da qual impugnou o documento em referência, desde que a expressão "pagar aviso", nele inserida, não foi pela empresa aposta na via entregue ao autor, através da qual fora manifestada concordância, sem qualquer reserva, a propósito do pedido de dispensa de cumprimento de aviso prévio, formulado no pedido de demissão em questão.

No entanto, muito embora a lei conceda à parte contra a qual foi produzido o documento o prazo de cinco dias para sobre o mesmo se manifestar (art. 398 do CPC), certo é que, na petição anexada à contra-capa dos autos, foi proferido o seguinte despacho: considerando os termos da ata de audiência de fls.11, devolva-se à peticionária, SP, 11.09.98.

Ora, E.Turma, ao indeferir a juntada de petição na qual o reclamante apresentava e fundamentava impugnação a documento apresentado pela parte contrária, antes mesmo de iniciado o prazo legal, o MMo. Juízo de primeiro grau praticou 
inadmissível cerceio de defesa, tornado nulos todos os atos praticados após 11.09.98 e, em especial, a r.decisão proferida, ora atacada.

Ao enunciar “desde que”, L1 torna inadmissível a não aceitação da impugnação por parte do juiz. Ao enunciar “certo é que”, L1 torna inadmissível aceitar-se a devolução da juntada da petição de pronto, se era direito do requerente obter análise e resposta ao seu pedido em até cinco dias. Estas estratégias, mais o uso de “ora”, recuam a argumentação para as razões do trabalhador e seus direitos legais, a fim de adentrar em seguida, e com mais vigor, no campo do jurídico. O recuo aponta ainda para eventuais falhas da própria instância julgadora, posição expressa na síntese promovida pelo segmento "inadmissível cerceio de defesa”, no quarto parágrafo. O apontar para tais falhas pode ser considerado índice do interdiscurso de crítica à prática da conciliação, uma vez que as audiências com tal fim são rápidas e sumárias - sujeitas a erros, portanto.

“No entanto" e “muito embora”, no terceiro parágrafo, apontam argumentativamente para as leis que teriam sido preteridas, redirecionando o texto para o especificamente jurídico.

Este texto possui ainda utilização mais farta do jargão jurídico de origem latina, se comparado ao texto anterior: “in verbis”, “a quo”. "data maxima venia”"52. Tal utilização, mais do que atestar a formação jurídica apurada do locutor-advogado, apontam com vigor para o campo do especificamente jurídico, avançando na argumentação. Afinal, é esta, por tradição, a linguagem do juiz, o interlocutor máximo que deverá, ao final, acatar a argumentação construída.

O enunciado “o que se admite apenas por amor ao argumento”, no nono parágrafo, é extremamente bem sucedido enquanto ato ilocutório e perlocutório, na medida em que torna inadmissível ao juiz não concordar com o mérito do julgado. Observe-se que o efeito de "é necessário admitir o outro" próprio a alguns operadores argumentativos pode ser conseguido através da construção de enunciados completos que não contenham tais

\footnotetext{
52 Tais expressões significam respectivamente: “literalmente”, “de quem, o qual”, “com a máxima e devida reverência”.
} 
operadores. O mesmo ocorre no texto 2 com o enunciado do quinto parágrafo: “o que se admite apenas para argumentar”.

Os textos 2 e 3 apresentam a mesma articulação. Recuos e avanços na argumentação, no sentido já explicitado, são costurados na superfície discursiva por operadores argumentativos, lexemas de uso específico no discurso jurídico e enunciados completos de forte efeito perlocutório. O enunciado grifado abaixo (originalmente no décimo primeiro parágrafo do texto 3) sintetiza a direção argumentativa, criando o sentido do "dever admitir a causa como procedente”:

Requer a notificação da reclamada para, querendo, responder aos termos desta reclamação trabalhista, sob cominação de, se revel, aplicar-se-lhe a pena de confissão, devendo ao final ser julgado procedente o pedido, acrescido de juros e correção monetária, além de custas e demais despesa processuais.

Embora a direção argumentativa leve ao acatamento do pedido por parte do juiz, tal acatamento tem sido menos comum no atual momento histórico brasileiro. Anos atrás, as decisões costumavam ser favoráveis ao trabalhador, devido principalmente ao reconhecimento das disparidades capital $\mathrm{x}$ trabalho por parte do juiz (apesar das ambigüidades inerentes a este locutor) e ao conseqüente alinhamento da prática jurídica trabalhista aos interesses do trabalhador. Interesses tais - nunca é demais frisar - que são a razão de existência do discurso jurídico trabalhista tal como o compreendemos hoje.

Com o avanço da formação discursiva pró conciliação, o juiz tende a assumir papel menos decisivo, na medida em que as partes, devidamente representadas, preferirão o acordo, tendo no juiz uma figura mais intermediadora e menos propriamente decisora. Desta forma, a direção argumentativa geral promovida em discurso tende a se alterar nos próximos anos, dependendo de como as formações discursivas do campo jurídico trabalhista negociarem seus espaços. Esta alteração implicará evidentemente mudança na representatividade discursiva dos interlocutores, o que inclui o sujeito trabalhador. 
CONSIDERAÇÕES FINAIS: PERSPECTIVAS DA PRÁTICA DISCURSIVA JURÍDICO-TRABALHISTA 


\section{CONSIDERAÇÕES FINAIS: PERSPECTIVAS DA PRÁTICA DISCURSIVA JURÍDICO-TRABALHISTA}

A prática discursiva jurídico-trabalhista constrói sujeitos que assumem níveis de representatividade distintos durante o processo trabalhista. Isto significa que tais sujeitos não são homogêneos, mas sim, e de acordo com o primado do interdiscurso, constitutivos de seus Outros. Estes Outros são passíveis de apreensão através das marcas polifônicas na superfície discursiva de textos concretos, que atestam a interdiscursividade constitutiva do discurso jurídico trabalhista e são a porta de entrada para a compreensão mais profunda desta interdiscursividade.

A representatividade discursiva do sujeito trabalhador, objeto desta tese, dá-se, como vimos, de forma bastante específica. Impedido de autodesignar-se legalmente EU em discurso, o sujeito trabalhador ocupa um lugar secundário na interlocução, lugar este que parece corresponder ao local que lhe é reservado na prática social. Mesmo ocupando a posição de elemento central da tríade interlocutiva do discurso jurídico trabalhista - que é formada essencialmente por três interlocutores $(\mathrm{L} 1=$ advogado, $\mathrm{L} 2=$ trabalhador e L3 = juiz), seu estatuto em relação aos demais interlocutores é diverso, pois sua fala, em cada fase do processo, é apropriada e refeita pelos demais locutores. Sendo este sujeito a razão de ser do discurso jurídico trabalhista, uma vez que dele depende a própria existência do dito discurso, esta posição deslocada causa no mínimo estranhamento, merecendo, portanto, ser mais bem compreendida.

A análise dessa representatividade (capítulo 5), apoiada nos pressupostos teóricos descritos nos capítulos 2, 3 e 4, aponta para a existência de um sujeito atravessado pelos discursos do mundo do trabalho que, ao atuar como sujeito de direito na luta por seus benefícios legais como trabalhador, constata não dispor dos conhecimentos jurídicos para tal (o que inclui conhecimentos discursivos e lingüísticos no campo do discurso jurídico trabalhista), sendo levado a delegar sua voz ao advogado trabalhista.

Esta prática discursiva reflete, constrói e perpetua uma certa forma de estar no mundo que caracteriza em especial o sujeito trabalhador brasileiro. Trata-se de um estar no mundo, por 
um lado, alheio às práticas jurídicas que lhe dizem respeito, e, por outro, alheio aos significados mais profundos das transformações que estão ocorrendo no mundo do trabalho. Embora a legislação permita que o trabalhador mova ação trabalhista sem um advogado que o represente, na prática social esta decisão se torna inviável, pois a precariedade dos conhecimentos especializados desse sujeito não lhe permite mover a ação por conta própria. Acrescente-se que, embora perceba que seus direitos trabalhistas estão sendo renegociados quase que à sua revelia, é levado a deles abrir mão aceitando negociações nem sempre favoráveis, pois crê que as transformações do mundo do trabalho não permitem acirrar a luta por direitos trabalhistas.

O sentido de uma representatividade assim construída aponta para um sujeito trabalhador com pouca margem de liberdade em discurso, uma vez que pouco participa da construção das cenografias dos gêneros oficiais/legais analisados (petição e audiência). O estatuto social desse trabalhador na esfera jurídico-trabalhista é, evidentemente, equivalente ao seu estatuto no discurso jurídico trabalhista, ou seja, o estatuto de um sujeito de participação periférica em matéria de seu interesse direto.

Ocorre que este cerceamento do sujeito trabalhador, graças à própria interdiscursividade do campo jurídico trabalhista, não é homogêneo nem definitivo. Se o OUTRO é constitutivo, se a alteridade é característica inerente aos discursos, a abertura para mudança também é constitutiva. Se os interdiscursos do mundo do trabalho são parte integrante do discurso jurídico trabalhista, inserindo-se em formações discursivas que representam/constroem mais fortemente certas posições num determinado momento sócio-histórico, é sempre possível a inversão de posições através do embate polêmico entre formações discursivas. Uma outra formação discursiva, mais representativa de interdiscursos do mundo do trabalho em prol do trabalhador, ou mesmo uma formação discursiva dentro do campo do especificamente jurídico que priorize o trabalho, pode sempre vir a ocupar mais espaços e renovar o discurso jurídico trabalhista em diferentes direções, incluindo uma direção que dê mais voz ao sujeito discursivo trabalhador, construindo um novo sistema de restrições semânticas que areje as cenografias dos gêneros petição e audiência e inclua a voz do trabalhador como sujeito em primeira pessoa. 
O sujeito discursivo trabalhador na cena enunciativa jurídico-trabalhista é antes de tudo sujeito de direito. Para ser sujeito de direito, ele é, antes ainda, sujeito capaz. O sujeito capaz é o que enuncia, mesmo que indiretamente via voz do locutor-advogado. Ora, esta intermediação pode vir a ser alterada por um novo jogo de forças discursivas, que permitam à voz do trabalhador vir a ser diretamente representada no referido discurso. $\mathrm{O}$ sujeito que enuncia, pelo simples fato de ser sujeito que enuncia, pode a qualquer momento tomar a palavra. Claro está que esta nova representação em discurso, ou seja, a representação do sujeito trabalhador no discurso jurídico trabalhista em primeira pessoa, não se dá ao acaso. Como L2, o sujeito trabalhador deverá agir para tomar posse de sua voz no referido campo. O que não significa agir só. Pode-se pensar numa nova tríade em que L1, L2 e L3 construam em discurso um novo estatuto para L2.

Esta construção relaciona-se diretamente com os processos de aquisição/construção da cidadania, de que tanto se fala atualmente. O sujeito cidadão é considerado o sujeito que participa diretamente dos assuntos de interesse de sua comunidade e não permite que falem por ele, exceto por sistemas de representação consensados e discutidos à exaustão. $\mathrm{O}$ sujeito cidadão é ainda aquele que tem acesso ao conhecimento e à informação. Daí a importância da educação, que deve ser entendida como processo constante através do qual o sujeito, a partir de sua vontade de sujeito individual (que assim se percebe por processos educacionais que começam na mais tenra infância), constrói-se a si mesmo como sujeito do mundo e sujeito social. Estes conhecimentos incluem, é claro, os conhecimentos lingüísticos e discursivos necessários à prática social. É impensável, portanto, uma condição cidadã que não tenha nascido de um longo processo de amadurecimento, do qual a educação é pilar construtor central. A cidadania plena é o caminho para oferecer ao sujeito as condições para que pleiteie seus direitos diretamente na justiça do trabalho, autodesignando-se EU.

A possibilidade de estabelecimento de uma nova tríade discursiva, conforme mencionado acima, em que L2 adquire novo estatuto em discurso, decorre da relação entre direito de solidariedade e direito trabalhista, proposta nesta tese. O aprofundamento desta relação pode lançar as bases para a consolidação de um novo paradigma que corresponderia, a nosso ver, a uma formação discursiva nova. Esta formação traria em seu bojo os elementos 
constitutivos capazes de restabelecer a conexão trabalho-vida, de que tratamos anteriormente. Afinal, a prática discursiva do sujeito nos discursos do mundo do trabalho, no qual se inclui o discurso jurídico trabalhista, corresponde a uma maneira de produzir-se a si mesmo. Quanto mais integrada às demais práticas desse sujeito - que é antes de tudo sujeito do mundo - mais feliz será esse produzir-se a si mesmo. Este produzir-se a si mesmo coincide com o movimento de reconexão trabalho-vida (ver capítulo 3) que, de forma incipiente, manifesta-se nos discursos predominantes do mundo do trabalho como um OUTRO incômodo.

Embora o capitalismo flexível vá na contra-mão da reconexão trabalho-vida, a compreensão do direito trabalhista como direito de solidariedade poderá tornar mais vantajosas as negociações para todos. Se o Direito, que recobre o direito trabalhista, traz na sua origem não só a vocação para o poder, mas também, e principalmente, a vocação para a paz social, cumpre dar vazão em discurso às vozes representativas desta última, em nome do equilíbrio social.

Até o presente momento, constatamos que, de fato, o discurso jurídico trabalhista pode ser considerado o local privilegiado de construção/expressão oficial da voz do sujeito trabalhador, embora de maneira limitada devido às coerções do próprio discurso e seus gêneros. Como discurso do mundo do trabalho, é no discurso jurídico trabalhista que se dão os embates significativos em prol da defesa dos direitos dos trabalhadores, cujos resultados têm valor legal e criam jurisprudência. Frise-se, no entanto, que é preciso que a tríade interlocutiva (L1 + L2 + L3) se articule para garantir que prevaleçam formações discursivas de fato benéficas ao trabalhador e que a representatividade da voz do sujeito trabalhador possa se dar de forma direta, considerando-se que esta possibilidade coincide com o fortalecimento do conceito de cidadania e de sua prática.

O momento histórico em nosso país, no que se refere às transformações no mundo do trabalho que interferem diretamente nas práticas da justiça do trabalho, é de embate entre duas formações discursivas antagônicas. A primeira alinha-se ao capitalismo flexível e tem, por ideologia, a flexibilização da legislação trabalhista e, por foco, no que se refere à prática jurídica, a conciliação nas disputas trabalhistas. Esta formação projeta-se para o futuro, acionando, para sua sustentação, interdiscursos do mundo do trabalho de cunho 
neoliberal, que alegam ser inviável a manutenção dos privilégios atuais dos trabalhadores. A segunda alinha-se a um tipo de capitalismo controlado pelo Estado, e tem por ideologia a manutenção da legislação trabalhista e, por foco, no que se refere à prática jurídica, a luta em juízo pelas maiores vantagens ao trabalhador. Esta formação alinha-se à corrente de juristas que prega a aplicação, sempre, da lei mais benéfica ao trabalhador, corrente esta que adquiriu caráter doutrinário no direito trabalhista brasileiro, embora encontre-se fortemente ameaçada. Projeta-se, portanto, para o passado. O presente é de embate entre tais formações, e de incerteza quanto ao seu desdobramento.

Estas duas formações discursivas no âmbito do campo jurídico trabalhista nasceram já mescladas a interdiscursos do mundo do trabalho, o que atesta sua interdiscursividade não apenas no campo especificamente jurídico. A formação discursiva alinhada ao capitalismo flexível articula-se com o interdiscurso que admite a instabilidade no trabalho como prática aceitável (o capítulo 3, como vimos, discorre em detalhes a esse respeito). Por seu lado, a formação discursiva alinhada a um capitalismo controlado pelo Estado articula-se com o interdiscurso oposto, que pressupõe a incapacidade do capitalismo flexível de garantir condições mínimas aos trabalhadores. As vozes deste interdiscurso, dialogicamente, acusam seu OUTRO de legitimar práticas de negociação empregado $\mathrm{x}$ empregador francamente desfavoráveis ao primeiro. Este interdiscurso alinha-se ao interdiscurso sindical, que, por sua vez, desaparece da superfície discursiva dos discursos do capitalismo flexível, que é seu OUTRO indesejável.

Os esforços enunciativos de superação do embate entre formações discursivas que ameaçam o espaço do trabalhador na esfera jurídico- trabalhista passam pela transformação da cenografia construída nos diferentes gêneros do discurso dessa esfera, em especial a petição, em que o deslocamento do sujeito trabalhador é maior. A cenografia deverá antes de tudo alterar a articulação da dêixis instaurada, permitindo ao sujeito trabalhador autodesignar-se EU. Deverá também alterar o modo de enunciação desse sujeito, que deixará de apresentar-se como “requerente” ou “reclamante”. Como dissemos, tais escolhas (que, num primeiro momento, referem-se à articulação da dêixis e do modo de enunciação) são a estratégia coesiva central, construindo o plano semântico modo de coesão de maneira a levar o texto numa certa direção. Estas estratégias, tal como se apresentam hoje, criam um 
recuo na direção argumentativa, pois remetem aos interdiscursos do mundo do trabalho. Embora tal recuo estratégico alimente os avanços na direção argumentativa - pois sem a interdiscursividade constitutiva com o mundo do trabalho não haveria discurso jurídico trabalhista - a alteração no modo de coesão tal qual ora proposto poderia tornar tais recuos mais consistentes, pois seriam enunciados a partir do sujeito trabalhador, de seu lugar social, sem intermediação. A direção argumentativa geral, conforme descrita no item 5.7 (A voz do trabalhador na cena enunciativa) se fortaleceria ao criar, via novas estratégias, uma representatividade renovada para o sujeito discursivo trabalhador.

Para concluir estas considerações, cabe sintetizar o que foi dito da seguinte forma: a petição trabalhista e os outros dois gêneros discursivos centrais que compõem o processo trabalhista (a entrevista, origem discursiva da petição; e a audiência, gênero conseqüente) são local privilegiado onde se faz presente a voz do trabalhador de modo oficial/legal, embora de forma indireta e construída fortemente dentro do paradigma idealista de um Direito positivo.

Como produto de certa cultura - calcada na realidade externa ao texto em que emerge - o discurso jurídico construído nas petições trabalhistas e documentos correlatos tem se mostrado o espaço discursivo em que a voz do trabalhador encontra eco, embora contida por estratégias lingüístico-discursivas que a colocam em plano subalterno. Tais estratégias desnudam um sujeito-trabalhador deslocado de seu contexto de ação social, envolvido contingencialmente em um discurso cujo jargão não domina e ao qual se submete, objetivando ver atendida sua solicitação perante a lei (o poder instituído). Esta, pretensamente acima do conflito capital $\mathrm{x}$ trabalho, teria o poder de equacionar $\mathrm{o}$ desnivelamento entre ambos, tarefa que cumpre de modo ambíguo, uma vez que se alinha idealmente às forças do poder de que é produto ao mesmo tempo em que, na prática, busca aplicar a lei sempre de modo a beneficiar o trabalhador (tendência doutrinária).

De um ponto de vista estritamente lingüístico-discursivo, ressaltamos neste ponto que o estudo realizado procurou demonstrar o quanto a argumentatividade inerente aos textos pode estar calcada em estratégias discursivas pouco palpáveis na superfície textual. Textos aparentemente homogêneos, de entendimento aparentemente simples, direto (como as petições trabalhistas) podem conter implícitas estratégias e orientações argumentativas que, 
uma vez apreendidas, abrem novos horizontes de compreensão. O entendimento amplo dessas orientações envolve considerar as condições de produção do texto e compreender os discursos envolvidos como interdiscursos, em que EU e OUTRO se constituem juntos. Por outro lado e ao mesmo tempo, desconsiderar aspectos contextuais e interdiscursivos pode levar o leitor a não apreender as pistas lingüísticas que todo texto deixa atrás de si, em prejuízo de seu significado.

As conseqüências dessa perda de sentido são funestas, a começar pela incapacidade de o leitor situar-se historicamente e entender com mais profundidade o momento sóciohistórico expresso no texto, em especial, no caso desta pesquisa, aquele relacionado ao mundo do trabalho nas sociedades ocidentais modernas, às quais o Brasil se alinha, se não como país modelo, mas como país que, ainda, imita suas práticas (por vício cultural e/ou necessidade econômica). O exercício da releitura de textos aparentemente simples, feita a partir dos pressupostos teóricos aqui expostos, pode conduzir à formação de leitores mais críticos e eventualmente produtores de significados renovados.

A renovação das práticas discursivas jurídico-trabalhistas por parte dos sujeitos que as enunciam, em especial o sujeito trabalhador, pode significar, em última análise, a ampliação dos modos de produzir-se a si mesmo em discurso, ou, em outras palavras, a possibilidade de exercitar o seu estar no mundo como cidadão.

O sujeito que enuncia e produz no trabalho e na vida é, antes de tudo, aquele que anseia pela coerência entre trabalho e vida, buscando sentido para sua existência. Privar o sujeito dessa busca é condená-lo a um progressivo afastamento do corpo social. Por outro lado, os esforços em prol dessa busca (como a proposta inovadora para atuação dos sindicatos esboçada por Gorz - ver capítulo 3 - ou mesmo a possibilidade aqui proposta de trabalhar pela modificação da cenografia dos gêneros do discurso jurídico trabalhista) significam enriquecer o corpo social com sujeitos plenamente capazes de nela integraremse. 
What is he? - A man, of course. Yes, but what does he do? - He lives, and is a man. Oh quite! But he must work. He must have a job of some sort. - Why?

Because obviously he's not one of the leisured classes. - I don't know. He has lots of leisure. And he makes quite beautiful chairs. There you are then! He's a cabinet maker!

- No no!

Anyhow a carpenter and joiner.

- Not at all. But you said so.

- What did I say?

That he made chairs, and was a joiner and carpenter.

- I said he made chairs, but I did not say he was a carpenter.

All right then, he's just an amateur.

- Perhaps! Would you say a thrush was a professional flautist, or just an amateur? - I'd say it was just a bird. - And I say, he is just a man..

D.H. Lawrence 


\section{BIBLIOGRAFIA}




\section{BIBLIOGRAFIA}

ACHARD, P. et al. Papel da memória. Trad. e introd. José Horta Nunes. Campinas, Pontes, 1999.

ALVES, V.C. A decisão interpretativa da fala em depoimentos judiciais. Dissertação de mestrado. Recife, UFPE, 1992.

ANSCOMBRE, J-C e DUCROT, O . L'argumentation dans la langue. Bruxelles, Pierre Mardaga, 1983.

APOTHÉLOZ, D. e M-J REICHLER-BÉGUELIN. Construction de la référence et strategies de designation. In: BERRENDONER, A . e REICHLER-

BÉGUELIN, M-J (eds.) Cahiers de praxématique - Référence, inférence: l'anaphore associative, n. 24. Praxiling, Montpellier III 1995 (227-271).

AUSTIN, J.L. Quando dizer é fazer: palavras e ação. Trad. Danilo M. de Souza Filho. Porto Alegre, Artes Médicas, 1990.

BAKHTIN, M. Marxismo e filosofia da linguagem. Trad. Michel Lahud e Yara Frateschi Vieira. São Paulo, Hucitec, 1997.

Estética da criação verbal. Trad. Maria Ermantina Galvão Gomes Pereira. São Paulo, Martins Fontes, 1992.

BOURDIEU, P. Razões práticas: sobre a teoria da ação. Trad. Mariza Corrêa. Campinas, Papirus, 2004.

Economia das trocas lingüísticas: o que falar quer dizer. Trad. Paula Montero. São Paulo, Edusp, 1996.

BRANDÃO, H. H. N. Gêneros do discurso: unidade e diversidade. In: Polifonia - Revista do programa de pós-graduação em estudos de linguagem-mestrado, n. 8. Cuiabá, UFMT, 2004. (pp. 95-112)

Da língua ao discurso, do homogêneo ao heterogêneo. In:

Brait, B. (org.) Estudos enunciativos no Brasil: histórias e perspectivas.

Campinas/São Paulo, Pontes/Fapesp, 2001.

Subjetividade, argumentação, polifonia: a propaganda da Petrobrás.

São Paulo, Editora da Unesp, 1998

(org.) Aprender e ensinar com textos didáticos e paradidáticos. São Paulo, Cortez, 1997. 
Pragmática lingüística: delimitações e objetivos. In: MOSCA, L. do L.S. (org.) Retóricas de ontem e de hoje. São Paulo, Humanitas, 1997 (pp. 183200).

Introdução à análise do discurso. Campinas, Editora da Unicamp, 1993.

A constituição da subjetividade no discurso da propaganda. In:

D.E.L.T.A., v. 7, n. 2, 1991.

BRAVERMAN, H. Trabalho e capital monopolista: a degradação do trabalho no século

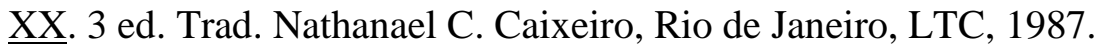

BRONCKART, J-P. Restrições e liberdades textuais, inserção social e cidadania. Texto avulso. Conferência inaugural XIV InPLA, PUC-SP, 22/04/2004.

CALIL, L.E.S. Breve história da justiça do trabalho no Brasil. In: Revista Unifieo, n.4. Osasco, Unifieo, 2001 (pp. 41-53).

CERVONI, J. A enunciação. São Paulo, Ática, 1989.

CORACINI, M. J. Um fazer persuasivo. São Paulo, Pontes/Educ, 1991.

COURTINE, J-J. Analyse du discours politique. In: Langages, n. 62. Paris, Larousse, 1981.

DI FANTI, M. da G. C. Discurso, trabalho e dialogismo: a atividade jurídica e o conflito trabalhador/patrão. Tese de Doutorado. PUC-SP, 2004.

DUCROT, O . Argumentação retórica e argumentação lingüística. Trad. Roberto Leiser Baronas e Fábio César Montanheiro. In: Polifonia - Revista do programa de pósgraduação em estudos de linguagem-mestrado, n. 8. Cuiabá, UFMT, 2004. (pp. 23-37)

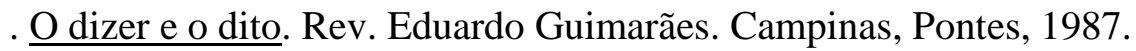

. Provar e dizer: leis lógicas e leis argumentativas. Trad. Maria Aparecida Barbosa. São Paulo, Global, 1981.

. Dizer e não dizer: princípios de semântica lingüística. Trad. Rodolfo Ilari e Carlos Vogt. São Paulo, Cultrix, 1977.

EAGLETON, T. After theory. New York, Basic Books, 2003.

ELUERD, R. La pragmatique linguistique. Paris, Nathan, 1985.

FAIRCLOUGH, N. Critical discourse analysis. London/New York, Longman, 1995. Language and power. New York, Longman, 1989. 
FARIA, J.E. Retórica, política e ideologia democrática: a legitimação do discurso jurídico liberal. Rio de Janeiro, Graal, 1984.

FARIAS, J.F.C. A origem do direito de solidariedade. Rio de Janeiro, Renovar, 1998.

FÁVERO, L. e KOCH, I. Lingüística textual: introdução. São Paulo, Cortez, 1983.

FERRARI, I., NASCIMENTO, A .M. e MARTINS FILHO, I.G.S. História do trabalho, do direito do trabalho e da justiça do trabalho. São Paulo, LTr., 1998.

FERRAZ JR., T.S. Teoria da norma jurídica: ensaio de pragmática da comunicação normativa. Rio de Janeiro, Forense, 1986.

. Direito, retórica e comunicação: subsídios para uma pragmática do discurso jurídico. São Paulo, Saraiva, 1973.

FLAHAULT, F. La parole intermédiaire. Paris, Seuil, 1978.

FOUCAULT, M. Microfísica do poder. 19.ed. Org. e trad. Roberto Machado. Rio de Janeiro, Graal, 2004.

A ordem do discurso. Trad. Laura F. de Almeida Sampaio. São Paulo, Loyola, 1996.

A verdade e as formas jurídicas. Trad. Roberto Cabral de Melo Machado e Eduardo Jardim Morais. Rio de Janeiro, NAU/PUC-RJ, 1996.

GENTILLI, P. e SILVA, T.T. da Neoliberalismo, qualidade total e educação. 4 ed. Petrópolis, Vozes, 1996.

GORZ, A. Metamorfoses do trabalho: crítica da razão econômica. Trad. Ana Montoia. São Paulo, Annablume, 2003.

GUERRA, V. M. L. Linguagem empresarial: a questão da polifonia e dos intertextos no discurso da CESP. Dissertação de mestrado, PUC-SP, 1996.

GUIMARÃES, E. Os limites do sentido: um estudo histórico e enunciativo da linguagem. Campinas, Pontes, 1995.

Polifonia e tipologia textual. In: Lingüística textual: texto e leitura. Série Cadernos da PUC, n. 20, São Paulo, Educ, 1986.

----------- . Sobre alguns caminhos da pragmática. In: Sobre pragmática. Uberaba, MG, FIUBE, 1983.

JAUBERT, A . La lecture pragmatique. Paris, Hachette, 1990. 
JULIO, M.T. e Munhoz, R. (orgs.) Textos clásicos de pragmática. Madrid, Arco/Libros, 1998.

KERBRAT-ORECCHIONI, C. L’implicite. Paris, Armand Colin, 1986.

KOCH, I. Argumentação e linguagem. São Paulo, Cortez, 1993.

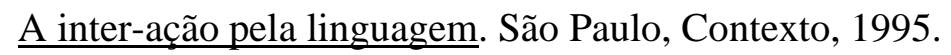

Expressões referenciais definidas. Texto avulso. Campinas, IEL-UNICAMP, 1998.

Estratégias de processamento textual. Texto avulso. Campinas, IEL-UNICAMP, 1999.

KOCH, I. e MARCUSCHI, L.A . Processos de referenciação na produção escrita. In D.E.L.T.A ., vol. 14, número especial, 1998 (169-190).

KRESS, G. Linguistic processes in sociocultural practices. Oxford, Oxford University Press, 1989.

LEVINSON, S. Pragmatics. Cambridge/New York/Melbourne, Cambridge Press University, 1983.

MADEIRA, H.M.F. A representação em juízo no direito romano. In: Revista Unifieo, n.1. Osasco, Unifieo, 2001 (pp. 9-13).

MAINGUENEAU, D. Diversité des genres de discours. Texto avulso. Palestra realizada na PUC-SP em 06/10/2003.

Análise de textos de comunicação. Trad. Cecília P. de Souza-e-Silva e Décio Rocha. São Paulo, Cortez, 2001.

Termos-chave da análise do discurso. Trad. Márcio Venício Barbosa e Maria Emília Amarante Torres Lima. Belo Horizonte, Ed. UFMG, 1998.

L'énonciation en linguistic française. Paris, Hachete, 1994.

Novas tendências em análise do discurso. Trad. Freda Indursky. Campinas, Pontes/Ed. da Unicamp, 1993.

- Genèses du discours. Bruxelas, P. Mardaga, 1984.

. Initiation aux méthodes de l'analyse du discours. Paris, Hachette, 1976. 
MAINGUENEAU, D. e COSSUTTA, F. Analysing self-constituting discourses. In: Discourse Studies, vol. 1, n.2, 1999 (pp 175-199).

L’ analyse des discours constituants. In: Langages, n. 117, 1995.

MACHADO, M. J. Linguagem empresarial: um estudo da polifonia e da ideologia no discurso de uma grande corporação. Dissertação de mestrado, PUC-SP, 1995.

MALHADAS, J.A. Justiça do trabalho: sua história, sua composição, seu funcionamento. São Paulo, LTr, 1998.

MARCUSCHI,L.A . Da fala para a escrita: atividades de retextualização. São Paulo, Cortez, 2001.

Referenciação e cognição: o caso da anáfora sem antecedente. In: PRETTI, D. (org.) Fala e escrita em questão, v.4. São Paulo, Humanitas, 2000 (pp.191-240).

-------------- . Referenciação e progressão tópica: aspectos cognitivos e textuais. In: XVII GELNE, Fortaleza, UFCE, 1999.

. Cognição e referenciação textual: processos de referenciação.

In: ABRALIN (II Congresso Nacional da Associação Brasileira de Lingüística), Florianópolis, UFSC, 1999.

. Contextualização e explicitude na relação entre fala e escrita. In: Anais do I Encontro de Língua Falada e Ensino. Maceió, Ed.da UFAL, 1995 (pp. 27-48).

Análise da conversação. São Paulo, Ática, 1991.

MARTINS FILHO, I.G.S. Manual esquemático de direito e processo do trabalho, 6 ed. São Paulo, Saraiva, 1998.

MAURO, M.A .F. Argumentação e discurso. In: MOSCA,L. do L.S. (org.) Retóricas de ontem e de hoje. São Paulo, Humanitas, 1997 (pp. 183-200).

MEY, J. Pragmatics: an introduction. Oxford/Cambridge, Blackwell, 1993.

As vozes da sociedade. Campinas, Mercado de Letras, 2001.

MOESCHLER, J. e REBOUL, A . La pragmatique aujourd'hui: une nouvelle science de la communication. Paris, Seuil, 1998.

Dictionnaire encyclopédique de pragmatique. Paris, Seuil, 1994.

MOURA, H. M. de M. Semântica e argumentação: diálogo com Oswald Ducrot. In: D.E.L.T.A., v. 14, n. 1, 1998. 
MUSSALIM, F. Análise do discurso. In: Introdução à lingüística: domínios e fronteiras, vol. 2. Org. Mussalin, F. e Bentes, A.C. São Paulo, Cortez, 2001.

NASCIMENTO, A .M. Curso de direito processual do trabalho, 18 ed. São Paulo, Saraiva, 1998.

Curso de direito do trabalho. São Paulo, Saraiva, 1991.

NERLICH, B. e CLARKE, D. Language, action and context (the early history of pragmatics in Europe and America: 1780-1930). Amsterdam/Philadelphia, John Benjamins Publishing Co., 1996. (coleção: Studies in the History of the Language Sciences)

. Language, action and context (linguistics pragmatics in Europe and America: 1800-1950). In: Journal of Pragmatics, v. 22, 1994.

ORLANDI, E. As formas do silêncio. Campinas, Ed. da Unicamp, 1992.

ORLANDI et al. Sujeito e texto. São Paulo, Educ, 1988.

ORLANDI, E. e GUIMARÃES, E. Unidade e dispersão: uma questão do texto e do sujeito. In: Cadernos PUC, São Paulo, 1986.

OSAKABE, H. Argumentação e discurso político. São Paulo, Kairós, 1979.

PARRET, H. Les sens et ses hétérogénéités. Paris, Éditions du Centre National de la Recherche Scientifique, 1991.

Enunciação e pragmática. Trad. Eni Orlandi et al. Campinas, Ed. da Unicamp, 1988.

PÊCHEUX, M. - Semântica e discurso: uma crítica à afirmação do óbvio. Trad. Eni Orlandi et al. Campinas, Ed. da Unicamp, 1988.

PERELMAN, C. Lógica jurídica. Trad. Vergínia K. Pupi. São Paulo, Martins Fontes, 1998.

Pragmática e dialogia. In: PERELMAN, C. Retóricas. Trad. Maria Ermantina G.Pereira. São Paulo, Martins Fontes, 1997.

Tratado da argumentação. Trad. Maria Ermantina Galvão G. Pereira.

São Paulo, Martins Fontes, 1996.

Justice, law and argument: essays on moral and legal reasoning. London,

D. Reidel Publishing Company, 1980. 
Études de logique juridique. Bruxellas, Emile Bruylant, v.1, n. 4, 1970.

PETRI, M.J.C. Linguagem jurídica. São Paulo, Plêiade, 1997.

Argumentação lingüística e discurso jurídico. São Paulo, Plêiade, 1995.

PICCARDI, T. A construção do sentido em textos empresarias institucionais: confronto de vozes e ideologia. Dissertação de mestrado. São Paulo, FFLCH/USP, 1999.

PLANTIN, C. L’argumentation. Paris, Seuil, 1996.

. Essais sur l'argumentation: introduction linguistique a l'étude de la parole argumentative. Paris, Kimé, 1990.

POSSENTI, S. Teoria do discurso: um caso de múltiplas rupturas. In: MUSSALIM, F. et al (orgs). Introdução à lingüística: fundamentos epistemológicos, vol 3. São Paulo, Cortez, 2004.

Os limites do discurso. Curitiba, Criar, 2002.

. Discurso, estilo e subjetividade. São Paulo, Martins Fontes, 1993.

RAHNEMA, M. Quand la misère chasse la pauvreté.Paris/Québec, Actes Sud/Fayard, 2003.

RAJAGAPOLAN, K. - A ideologia do suprimido; ou, como não teorizar a respeito da ideologia. In: D.E.L.T.A., v. 14, n. 1, 1998.

RAWLS, J. Uma teoria da justiça. São Paulo, Martins Fontes, 1997.

REALE, M. Filosofia do direito. São Paulo, Saraiva, 1965.

RÈCANATI, F. - Le développement de la pragmatique. In: Langue française, n. 42. Paris, Larousse, 1975.

RICOEUR, P. Le juste. Paris, Éditions Esprit, 1995.

RODRIGUES, L.M. Destino do sindicalismo. São Paulo, Edusp/Fapesp, 2001.

ROMUALDO, E.C. A construção polifônica das falas na justiça: as vozes de um processo crime. Tese de doutorado. Assis, Fac.Ciências e Letras-Unesp, 2002.

SACHS, I. Exclusão social pelo trabalho decente: oportunidades, obstáculos, políticas públicas. In: Estudos Avançados, vol.18, n. 51, São Paulo, 2004.

SADER, E. e GENTILLI, P. (orgs.) Para além do neoliberalismo. Rio de Janeiro, Paz e Terra, 1995. 
SALZANO, J.T. A linguagem de especialidade em um processo do tribunal de contas. Uma contribuição para a análise de um "genre”. Dissertação de Mestrado. PUC-SP, 1992.

SEARLE, J. R. Speech acts: an essay in the philosophy of language. Londres, Cambridge University Press, 1969.

SENNETT, R. A corrosão do caráter: conseqüências pessoais do trabalho no novo capitalismo. Trad. Marcos Santarrita. Rio de Janeiro, Record, 1999.

SOUZA- E-SILVA, M. C. P. Estudos enunciativos: atividades de linguagem em situação de trabalho. In: Brait, B. (org.) Estudos enunciativos no Brasil: histórias e perspectivas. Campinas/São Paulo, Pontes/Fapesp, 2001.

-------------. Interação: negociação de sentido. In: Intercâmbio: uma publicação de pesquisas em lingüística aplicada, vol. IV. LAEL, PUC-SP, 1994.

La réunion de travail: une histoire sans fin. In: Direct Papers, n. 14, São Paulo, CEPRIL, 1994.

- The analysis of verbal interactions: a meeting. In

BARBARA, L. e SCOTT, M. (orgs.) - Reflexions on language. Multilingual Matters, Clevedon, Philadelphia, Adelaide, 1994.

SOUZA FILHO, D.M.de Filosofia, linguagem e comunicação. São Paulo, Cortez, 1983.

SCHWARTZ, Y. C’est compliqué: activité symbolique et activité industrieunse. In: Langages, n. 93. Paris. Larousse, 1989.

. L’homme, le marché, la cité (entrevista). In: MONTELH, B. (org.) C’est quoi le travail?, Collection Mutations, n. 174, Paris, Éditions Autrement, 1997.

VERSCHUEREN, J. Whose discipline? Some critical reflections on liguistic pragmatics. In: Journal of Pragmatics, n. 31, 1999 (pp. 869-879).

VIANA, M.T. (org.) Discriminação. São Paulo, LTr, 2000.

VIGNAUX, G. L'argumentation: essai d'une logique discursive. Librairie Droz, Genève-Paris, 1976.

VOGT, C. Linguagem, pragmática e ideologia. São Paulo, Hucitec, 1980. 


\section{ANEXO A}

Transcrição parcial da entrevista advogado-trabalhador 


\section{ANEXO A \\ TRANSCRIÇÃO PARCIAL DA ENTREVISTA ADVOGADO-TRABALHADOR}

(Gravação realizada em 5/2/2003)

Critérios para a transcrição:

1. Adotamos os critérios para transcrição definidos para o projeto NURC ${ }^{53}$. Obs.: a norma para transcrição de superposição ou simultaneidade, cujo sinal é o traço ligando as duas linhas, foi preterida, preferindo-se, para facilitar a digitação, assinalar eventos do tipo como comentário do transcritor.

2. Foram omitidos os trechos que não trataram diretamente do assunto em pauta na entrevista. Tais trechos omitidos são basicamente conversas paralelas diversas entre os presentes, falas ao telefone, brincadeiras, digressões e tomada de notas de dados simples, como endereços e telefones.

Contextualização:

Envolvidos no processo ${ }^{54}$ :

Escritório: Mendonça Sampaio Advogados Associados, com sede na cidade de São Paulo Advogado: Dr. Marques

Cliente: Sr. José da Silva

Causa: Reclamação contra o Banco do Estado de São Paulo para obtenção de horas-extras

Legenda:

L1 advogado

L2 trabalhador/requerente

A1 advogado auxiliar (Márcio)

A2 colega de trabalho do trabalhador/requerente (Marcos), que já havia entrado com causa semelhante contra o mesmo empregador.

\footnotetext{
${ }^{53}$ Projeto de Estudo da Norma Lingüística Urbana Culta de São Paulo (Projeto NURC/SP). FFLCH-USP.

${ }^{54} \mathrm{O}$ nome do trabalhador é fictício, a fim de preservar sua identidade.
} 
Normas para transcrição:

\begin{tabular}{|c|c|c|}
\hline OCORRÊNCIA & SINAL & EXEMPLIFICAÇÃO \\
\hline $\begin{array}{l}\text { Incompreensão de palavras } \\
\text { ou segmentos }\end{array}$ & $(\quad)$ & $\begin{array}{l}\text { do nível de renda ( } \\
\text { nível de renda nominal }\end{array}$ \\
\hline Hipótese do que e ouviu & (hipótese) & $\begin{array}{l}\text { (estou) meio preocupado } \\
\text { (com o gravador) }\end{array}$ \\
\hline $\begin{array}{l}\text { Truncamento } \\
\text { homografia, usa-se acento } \\
\text { homdo } \\
\text { indicativo da tônica e/ou } \\
\text { timbre) }\end{array}$ & I & e comé/ e reinicia \\
\hline Entonação enfática & maiúscula & $\begin{array}{l}\text { porque as pessoas reTÊM } \\
\text { moeda }\end{array}$ \\
\hline $\begin{array}{l}\text { Prolongamento de vogal e } \\
\text { consoante (como s, r) }\end{array}$ & $\begin{array}{l}\because: \text { podendo aumentar para :::: } \\
\text { ou mais }\end{array}$ & $\begin{array}{l}\text { ao emprestarem... éh::.:.... } \\
\text { dinheiro }\end{array}$ \\
\hline Silabação & - & por motivo de tran-sa-ção \\
\hline Interrogação & $?$ & e o Banco... Central... certo? \\
\hline Qualquer pausa & $\cdots$ & $\begin{array}{l}\text { são três motivos... ou três } \\
\text { razões... que fazem com que } \\
\text { se retenha moeda... existe } \\
\text { uma... retenção }\end{array}$ \\
\hline Comentários do transcritor & $(($ minúscula $))$ & $(($ tossiu $))$ \\
\hline $\begin{array}{l}\text { Comentários que quebram a } \\
\text { seqüência temática da } \\
\text { exposição; desvio temático }\end{array}$ & -- $\quad--$ & $\begin{array}{l}\text {.... demanda de moeda - - } \\
\text { vamos dar essa notação - - } \\
\text { demanda de moeda por } \\
\text { motivo }\end{array}$ \\
\hline $\begin{array}{l}\text { Indicação de que a fala foi } \\
\text { tomada ou interrompida em } \\
\text { determinado ponto }\end{array}$ & $(\ldots)$ & (...) nós vimos que existem... \\
\hline $\begin{array}{l}\text { Citações literais ou leituras } \\
\text { de textos, durante a } \\
\text { gravação }\end{array}$ & “ ” & $\begin{array}{l}\text { Pedro Lima ... ah... escreve } \\
\text { na ocasião... “O cinema } \\
\text { falado em língua estrangeira } \\
\text { não precisa de nenhuma } \\
\text { baRREIra entre nós”... }\end{array}$ \\
\hline
\end{tabular}

Observações:

$\checkmark$ Iniciais maiúsculas: só para nomes próprios ou para siglas.

$\checkmark$ Fáticos: ah, éh, ahn, ehn, uhn, tá.

$\checkmark$ Nomes de obras ou nomes comuns estrangeiros são grifados.

$\checkmark$ Números: por extenso.

$\checkmark$ Não se indica o ponto de exclamação em frase exclamativa.

$\checkmark$ Não se anota o cadenciamento da frase.

$\checkmark$ Podem-se combinar sinais.

$\checkmark$ Não se utilizam os sinais de pausa próprios à língua escrita: ponto e vírgula, ponto

final, dois pontos e vírgula. As reticências marcam qualquer tipo de pausa. 
$1^{\circ}$. TRECHO: LEVANTAMENTO DE INFORMAÇÕES QUANTO AO HORÁRIO DE TRABALHO

$[\ldots]$

L2 Eu vou ter que mandar uma cópia da::... da carteira profissional... por sedex aqui no seu endereço... aí tem que pegar o nome... endereço... telefone e o CEP das testemunhas ... que são três... né?

A1 É.

L1 José...vamos só jogar essa mesinha um pouquinho mais pra trás...aí pro Márcio ficar mais à vontade... (isso) ... aí... aí...

L2 Reúno todos os holerites ...

A1 E recibo dos últimos cinco anos dos holerites...

L1 Ah... a:: .... de contrato taí?... tá... deixa eu ver:.... só levanta ela... pode baixar...

L2 Tem até coisa aqui de:: ... da Caixa Econômica...

L1 Agora:: ... o problema é esse ... nosso::.... eu comentei com você ... você teve prejuízo já...

L2 De um ano...

L1 Prejuízo de um ano... né?... porque acontece o seguinte... quando nós entramos com o processo... nós temos dois anos pra entrar com o processo... e ele retorna... ele retroage cinco... entendeu? Mas cinco é contado da data da::... da... justificação... então por exemplo 
...nós vamos ( ) essa justificação... vamos colocar o quê:: ... dia dez de fevereiro?... então nós vamos retroagir para dez de fevereiro de mil novecentos e noventa e oito ( ) você já perdeu aqui:: ... ( )

L2 É...

L1 ( ) é uma pena... né? se tivesse colocado... ( )

L2 Não... eu:.... eu quis matar... é:: ... é aquela coisa de... aquela coisa de deixar com amigo... entendeu? ele ficou insistindo tanto... porque eu não queria... né? porque o Didi falou comigo... tal... né? aí eu falei ó... eu vou entrar com vocês... aí o cara falou não... é só... você sabe... eu moro junto aí com você... entra comigo ( ... aí o cara encheu tanto o meu saco... que eu acabei deixando com ele... falou... ( ) qualquer coisa você me liga... $(\ldots)$

L1 Quando é que você foi pra Vila Mariana...((hesitação)) ... você:: ... quando contratado... já foi pra Vila Mariana?

L2 Não ... eu era da:: ... eu fui ( ) Moema, trabalhei aqui na Ibirapuera, no (posto) do Ibirapuera...

\section{L1 Quanto tempo mais ou menos?}

L2 ((hesitação)) uhn:: ... só até noventa e seis ...

\section{L1 ( ) Moema?}

L2 É::...

((vozes simultâneas)) 
L1 Aí de Moema você foi pra Vila Mariana...

L2 Daí eu fui pro Detran...

L1 Não... pra Vila Mariana...

L2 É:: ... agência Vila Mariana do posto do Detran.

L1 Ok... Aí você ficou no posto e aí depois você voltou pra agência...

L2 É... não... eu não cheguei a ir pra agência... eu fui direto... né? eu fui ... ((hesitação)) da agência de Moema...

L1 É que você falou pra mim que nos últimos cinco anos você tinha trabalhado em dois lugares...

L2 Isso... quatro no Detran e um na Vila... Detran é um posto da Vila Mariana...

L1 Tá...

L2 Um posto da Vila Mariana...

L1 Você trabalhou um ano lá...

L2 Na agência sim... e quatro lá no posto... lá no Detran...

L1 Que ano que foi isso aí... na agência?

L2 Foi no último ano... foi dois mil e um... né?

A2 Dois mil e um ... 
L1 Na agência?

L2 Foi no último ano...

L1 E os quatro anos anteriores no Detran?

L2 Isso...

L1 E efetivamente quanto:: ( ... que ninguém nos escute...

L2 Óh... no Detran tinha:: ... a gente teve vários horários ... eu:: ... eu quando entrei no Detran trabalhava na área de ( ... então eu entrava ... entrava tipo duas da tarde mas tinha dia que eu saída onze horas... meia-noite... tinha dia que eu saía às oito... não tinha um horário fixo...

L1 Mas o teu horário CONTRATUAL ... que horário era... o contratual? era das dez às dezesseis?

L2 Nesses últimos quatro anos?

L1 É...

L2 Não... tinha vários... tinha das seis até meio-dia... que eu entrava no Detran... tinha das sete até a::: ...até a uma...

L1 Eu preciso que você me detalhe isso... eu preciso que você me detalhe isso... ( )

L2 Ah... tá... acho que eu não sei se eu vou conseguir falar assim porque não tinha::... era registro de agência... por exemplo... a gente assinava o ponto... 
L1 Mas veja bem... o Banespa vai mostrar lá pro juiz o ponto assinado por você...

\section{L2 Sim...}

L1 E esse ponto é cheio... o que é ponto cheio? você entrava às sete horas e saía treze horas...

L2 É... é isso que eu tava falando pro (...)

L1 Você nunca vai entrar sete e um... sete e dois... você vai entrar sempre sete horas e sair treze horas...

L2 É mas aí a gente assinava ... eles mandavam a gente assinar tipo:.... é::...sei lá::...

L1 Um... dois... três... quatro... cinco... seis... fazer uma:....

L2 É... não... fazia assim... coloca:: ....

L1 Sim... mas isso agora...

L2 Seis e quinze...

L1 Não... mas de um ano e meio pra cá...

((estas últimas quatro falas quase simultaneamente))

L2 Isso...

L1 Mas antes não... antes era cheio...

L2 Hã hã... é::... 
L1 e L2 Antes era cheio... ((simultaneamente))

L2 É...

L1 Então veja bem... eu não posso falar do horário de trabalho sem isso daqui ( ) Eu tenho que dizer que aquele seu horário de trabalho::... só vou concordar com o horário de entrada... ( ) o horário de saída eu protesto. Só com o horário de entrada ( ) eu não posso ( ) no empírico... nós precisamos colocar a realidade dos fatos...

\section{L2 É::...}

L1 Eu preciso que você... você assine aí qual o período que você entrava... de tanto a tanto eu entrei no horário tal e saí no horário tal... contratual... não quero saber o horário verdadeiro que você saiu... não interessa...

L2 Certo... por que (...)

\section{L1 Certo?}

( )

L2 Bom... na agência:.... era o horário normal de agência... né?

$($ )

L1 Na agência você trabalhou de quando a quando?

L2 Setembro::... foi de setembro ... não lembro se é outubro de dois mil... até setembro de dois mil e um... alguma coisa tipo assim... 
L1 Na agência Vila Mariana?

((L2 assente com a cabeça))

L1 Outubro ou setembro... vamos trabalhar com (setembro)... setembro de dois mil a setembro de dois mil e um... e você trabalhou na agência da Vila Mariana... ok?

L2 É::... de um ano... né? ((simultânea desde a metade da fala anterior))

L2 Isso...

L1 E na agência Vila Mariana era horário contratual?

L2 Isso... lá era horário contratual...

L1 ( )

L2 Isso...

L1 Aí teve aquele...

L2 O horário anterior era das nove...

L1 Entrava nove e trinta...

L2 Isso...

((L2 confirma rapidamente com A2 o horário))

L1 Então você teve o horário das nove às quinze... você teve o horário das dez... mas você lembra de ter tido às nove e trinta ...? 
L2 Uhn... não... quebrado não...

L1 Só os dois... O horário era das nove... das nove às quinze e das dez às dezesseis... é isso?

L2 Isso...

L1 Bem fácil...

L2 No Detran tive horário...

L1 Na agência... na agência... vamos ficar na agência... que é esse último ano...

\section{L2 Certo...}

L1 Como é que é lá:: ... você marcava o horário... esse horário ( .... marcava sempre dezesseis horas?

L2 É:: ... lá sempre é assim.... não... não... lá era aquele horário picadinho... eles marca quinze... marca dez... cinco pras (...) ... eles sempre davam quinze minutos... entendeu? eles falavam assim... então marca dez pras dez e a saída:: ... ((hesitação)) dezesseis e cinco... eles ficavam ... ( ) esses 15 minutos...

L1 Marca um... marca dois... dezesseis e um... dezesseis e dois ... bom... de setembro... então... de agosto de dois mil e um ... agosto dois mil... agosto de noventa e nove... agosto noventa e oito... você estava no Detran...

L2 Isso... tava no Detran... aí...(...)

L1 A partir de agosto de noventa e oito ou noventa e sete? 
L2 É... nesse caso sim... né? mas na realidade eu comecei a trabalhar bem antes... né?

L1 Não... não... eu quero::.... eu quero saber a data que você começou a trabalhar mesmo... a verdadeira data... que você começou a trabalhar no posto...

L2 Eu saí da ... quando foi que acabou a ( )?

A2 Então... ( ) ((hesitação)) foi em noventa e cinco....

L2 Noventa e cinco...

A2 Noventa e cinco...

L2 É... foi de noventa e cinco até:: ... até::: ...

L1 Vamos colocar desde o ano de mil novecentos e noventa e cinco até agosto de::... (...)

L2 Espera aí... vamos dar uma pesquisada... vamos lembrar melhor...

((L2 e A2 revêem datas))

L1 Mas isso... isso... isso foi até:.... isso foi até setembro... até agosto de dois mil? em setembro de dois mil você passou para a Vila Mariana?

L2 É::... agosto de dois mil... porque em setembro eu tava na Vila Mariana...

L1 E em setembro de dois mil você passou pra Vila Mariana... e o Detran... qual o horário contratual que você fez nesse período... nesses últimos quatro anos aí? 
L2 Então... aí que tá... tinha das seis::... das seis::... a gente assinava das seis até o meiodia... aí tinha depois das sete... eu acho que tinha vários horários... mas eu anotava das:: ... das:.... seis... é... teve vários horários... das seis ao meio-dia... (...)

L1 Mas veja bem... então das seis às doze...

L2 Isso...

L1 Depois das sete até a uma... das sete às treze...

L2 Isso...

L1 Que mais?

L2 Tinha dia que a gente fazia das oito às quatorze... é que lá era um horário...

A2... O que tava escrito na folhinha? É isso que ele quer saber...

L1 O que assinava na folhinha?

L2 Lá era das::... das seis ao meio-dia...

L1 Direto todas as folhas? ( ) quando você entrava seis horas da manhã você entrava às seis horas da manhã?

L2 É... tinha que entrar até antes... né?

L1 E quando você entrava às oito... você entrava às oito?

L2 Um pouquinho antes também... 
L1 Então você sabe que você entrava das seis às oito...

L2 Mas:: ... mas não que eu assinasse separado... eu acho que eu sempre assinava das seis ao meio-dia...

L1 Esse eu acho é que...

L2 É::... o eu acho é um problema...

L1 Puxa pela cabeça aí... se eu falar eu acho.... eu tô perdido...

L2 ( ) É... quando eu comecei... eu comecei... eu comecei à TARde... mas:. ... mas nos últimos quatro anos foi de manhã mesmo...

L1 Você chegou a trabalhar no horário das oito?

L2 Eu trabalhei... mas eu não assinava assim o horário das 8...

L1 Das oito às quatorze... você chegou a assinar isso?

L2 Não... eu assinava um horário só... agora não lembro se era das seis ao meio-dia ou se era das sete a uma...

((L2 e A2 conversam sobre horário e colegas que trabalharam nos mesmos horários e que deverão testemunhar))

L2 É que lá tinha duas turmas... né? E essa turma que eu chamei são mais chegados assim...

L1 Nós vamos chegar lá... mas o problema é saber esse horário...

L2 Será que tem como eu ir lá no Detran e verificar isso aí lá no departamento pessoal? 
L1 ( )

L2 Não... não... lá é tudo amigo...

L1 ( ) porque... veja bem... você pode até perguntar... mas o problema é que （） ... não tem outro colega que você possa ligar e perguntar pra ele?

L2 Que trabalha no período da manhã ... só se for:: ...

L1 Pega o telefone dele....

L2 Não sei se ele vai estar lá ainda...

((movimento para providenciar o telefonema ao colega))

L1 A gente tem que trabalhar em segurança...

L2 É:: ... claro... uma hora que erra...já...

L1 Você já passou ((dirigindo-se a A2))... você sentou na cadeirinha de espinhos... você sabe...

((vozes simultâneas))

L1 Se você errar num detalhe... eles fazem ... um carnaval...

( )

((enquanto L2 confirma o horário com o colega por telefone, L1 e A2 conversam)) 
L1 Das sete às treze?

L2 É::... é:: ... mas na verdade das seis ao meio-dia...

L1 Tudo bem... contratual das sete às treze...

L2 Isso...

$2^{\circ}$. TRECHO: SOBRE HORÁRIO DE SAÍDA NA AGÊNCIA DO DETRAN, PASSAGEM DO CARGO E ORIENTAÇÃO ÀS TESTEMUNHAS

$($ )

L2 A exigência da diretoria do Detran era que a gente fizesse/ abrisse... no período em que o Detran...

A2 Que é das seis às seis...

L1 Que horário você fazia no Detran?

L2 Eu acho que:: ... das oito... das oito às cinco... éh::...

L1 O expediente então era das oito às dezessete...

A2 Mas a gente chegou a atender despachante seis horas da manhã...

L2 É... despachante chegava ... tinha dia que a gente ficava... (...)

L1 Mas é possível alguém fazer uma transação bancária depois do horário bancário? 


\section{L2 Lá?}

A2 Sim... sim ... ((simultaneamente à fala anterior))

L2 (...) É igual a ... como se fosse um caixa eletrônico... chega lá... se tiver uma fila muito grande...você atende... mesmo na agência... quando fechava às quatro... tinha aquela fila até a porta ... você ficava lá... até cinco... seis horas... porque o Banco....

L1 Tem correntista... tem correntista... lá::... lá no posto do Detran... não tem?

L2 Tem ...têm correntistas e não correntistas... lá a gente... como todo Banespa a gente atende todo mundo... né? só que era separado... né? por exemplo... tinha despachante... auto-escola... aí público... né?

L1 Você me manda aqueles holerites do ( ... eu vou precisar deles... teu caso, teu caso é um caso bem mais fácil... porque não vai ter como o Banco ... o problema... o problema não é que ele ficava até dezessete e trinta... ele não fazia parte do segundo turno... ele fazia parte do primeiro... então ...

L2 As testemunhas são todas do segundo turno...

( )

L1 Pra mim não importa a hora que você entra...

L2 Então... eu... eu... achei até que foi bacana... assim ... não sei... né? .... pensando... assim... com minha cabeça... de ter arrumado duas pessoas que trabalharam comigo... mas no período da tarde... quer dizer... eles viam a gente sair... viam a hora que a gente saía... né? 
L1 Alguma dessas testemunhas... você passava o cargo pra eles?

L2 Às vezes sim... porque... sabe... a gente tinha um rodízio... né?

L1 Então passou a passar sempre... tá?

\section{L2 Ahn?}

\section{L1 Passou a passar sempre...}

L2 Ah...tá... há... há...

L1 Se falar a verdade eu tenho outro...

L2 Não... agora... é o que eu tô falando... tô falando a verdade... né? só eu sei... (...)

L1 Não... porque aí você vai falar "não... eu saía treze horas”... mas aí ó... e você... “eu entrava treze horas”.... tudo bem ... e que horas que o José saía? “o José me passava o caixa”... e quanto tempo ele levava pra te passar o caixa? “ah... uns quarenta... quarenta e cinco minutos” .... pra passar o caixa ( ) entendeu? mas aí depois as testemunhas vêm aqui... vamos bater papo... eu vou orientar as testemunhas pro que elas devem dizer... pra gente não ter surpresa lá... né.... Marco?

A2 Ô...

((A2 fala um pouco da sua experiência))

L1 É muito simples... o juiz pergunta pra você o seguinte... o juiz chega pra você... e você tá lá... você já tá numa situação de nervoso... né? ... aí o juiz pergunta pra você... ( )... aí o cara pega e te pergunta “quem descobriu o Brasil?”... aí o que você tem que dizer pro cara? Pedro Álvares Cabral... aí o cara pega e fala assim... “olha... trabalhei na Pinta e Nina... 
sabe? ... trabalhei na Pinta e Nina... é isso aí... na expedição ( aí:: ... aí chegou lá .... aí chegou lá numa ilha e rezaram a primeira missa” ... o juiz não perguntou nada disso... o juiz perguntou "quem descobriu o Brasil” ... você entendeu? e o cara começa a falar de:: ... da primeira missa do Brasil ( )

((risos, falas simultâneas sobre o assunto)) 


\section{ANEXO B}

Petição inicial para pedido de hora-extra (texto na íntegra) 


\section{ANEXO B \\ PETIÇÃO INICIAL PARA PEDIDO DE HORA EXTRA (TEXTO NA ÍNTEGRA ${ }^{55}$ )}

Excelentíssimo Senhor Doutor Juiz da Meritíssima Vara do Trabalho de São Paulo - Segunda Região.

(1)

JOSÉ DA SILVA ${ }^{\mathbf{5 6}}$, nascido em 07 de Setembro de 1967, brasileiro, casado, bancário, portador da Carteira Profissional $n^{0} 5.690$, série $117^{\mathrm{a}}$, devidamente inscrita no C.P.F/M.F. sob $n^{0} 129.154 .478 / 02$, residente e domiciliado no Estado da Bahia, Município de Boa Nova, Rua Regis Pacheco ${ }^{\circ}$ 04, CEP. 45.250-000 neste ato, assistido por seu advogado e bastante procurador judicial que esta subscreve, ut instrumento de mandato incluso, vem com o devido respeito e acato a Vossa Excelência, propor a presente RECLAMAÇÃO TRABALHISTA, contra BANCO DO ESTADO DE SÃO PAULO S/A - SANTANDER estabelecido nesta Comarca de São Paulo, Bairro do Centro, Rua Dr. Falcão $\mathrm{n}^{\circ}$ 56, $11^{\circ}$ andar, CEP. 01007-900, inscrito no C.N.P.J. ${ }^{0}$ 61.411.633/0488-99, tudo nos termos dos artigos 840 e seguintes da Consolidação das Leis do Trabalho e pelos relevantes motivos de fato e de direito que passa a expor:

(2)

Esclarece o reclamante que é pessoa pobre na acepção jurídica do termo, não estando em condições de demandar sem sacrifício próprio e familiar, motivo pelo qual requer que essa I. Vara lhe conceda os benefícios da JUSTIÇA GRATUITA, previstas na Lei 1.060/50, com a redação que lhe deu a Lei 7.510/86, juntando para tal fim a inclusa declaração de que trata a Lei 7.115/83.

\section{“ACESSO CONSTITUCIONAL À JUSTIÇA - ASSISTENCIA JUDICIÁRIA GRATUITA - LEI 1.060/50 - C.F. ARTIGO 5 ${ }^{\circ}$, LXXIV.}

\footnotetext{
${ }^{55} \mathrm{O}$ texto está tal qual foi apresentado ao juiz, sem alterações/ajustes/correções de qualquer espécie.

${ }^{56}$ Nome fictício. O verdadeiro foi suprimido a fim de preservar a identidade do trabalhador.
} 
Assistência judiciária integral e gratuita aos que comprovarem insuficiência de recursos, não revogou a de assistência judiciária gratuita da Lei 1.060 de 1.950, aos necessitados, certo que, para obtenção desta declaração, feita pelo próprio interessado, de que a sua situação econômica não permite vir a juízo sem prejuízo de sua manutenção ou de sua família. Essa norma infra constitucional põe-se, ademais, dentro do espírito da Constituição, que deseja que seja facilitado o acesso a todos à justiça $\left(C F\right.$, art. $\left.5^{\circ}, X X X V\right)$ “

(STF- RE - 205029-6, $2^{a}$ T, Rel. Min. Carlos Velloso, DJU 07.03.97 in Síntese Trabalhista, ST - 94 - abr/97, verbete 9997, pg. 74. )

(4)

$O$ reclamante cadastrado sob o código de empregado número 6931810847701 foi admitido aos serviços do Banco-reclamado em data 23 de Maio de 1.988 e demitido sem justa causa em 20 de Setembro de 2.001. Exercia a função de Escriturário Caixa - qualificada no Grupo I nível $\underline{F}$ do Quadro de Carreira, percebendo por último o salário mensal de $\mathrm{R} \$ \mathbf{1 . 8 5 1 , 7 1 .}$

A rescisão contratual do reclamante foi homologada perante à Delegacia Regional do Trabalho, oportunidade em que àquela autarquia, nos termos do Enunciado 330 do Colendo tribunal Superior do Trabalho, fez a seguinte ressalva no Termo de Rescisão Contratual:

“A quitação abrange apenas os valores discriminados no presente termo, ficando expressamente ressalvados todos os demais direitos não satisfeitos integral ou parcialmente na vigência do contrato de trabalho, bem como os decorrentes da injusta dispensa."

Desde o ano de 1994 até a data de sua demissão ocorrida em 20 de Setembro de 2.001 o reclamante laborou no Posto de Serviços do Departamento Estadual de Trânsito de São Paulo, cujo o expediente ao público é de $2^{\mathrm{a}}$ à $6^{\text {a }}$ feiras das $08 \mathrm{~h} 00$ às $17 \mathrm{~h} 00$. 
(8)

No exercício da função de Caixa, subordinava-se à jornada contratual de 6 (seis) horas diárias, com início às 07 h00 e término às $13 \mathrm{h00}$, isto de Segunda às Sextas-feiras, usufruindo de intervalo para descanso de 15 minutos.

(9)

Fato é que a reclamante iniciava seu expediente em média às $06 \mathrm{~h} 00$ e encerrava-o às 14h00. Todavia, por exigência do Banco-reclamado, lhe era obrigado a assinalar em folha de frequência o horário contratual, jamais a efetiva jornada laboral prestada além daquele horário , conforme demonstrará provado em instrução processual.

(10)

Inobstante a reclamante haver laborado no horário extraordinário acima, de modo habitual, desde sua admissão ocorrida em maio de 1988 até sua demissão ocorrida em setembro de 2.001, o Banco-reclamado não remunerou horas extras ao reclamante.

Pleitea a reclamante a condenação do Banco-reclamado em 2 (duas) horas diárias, as quais deverão ser pagas com o adicional constitucional de 50\%, com a devida integração dessas no $13^{\circ}$ salário, nas gratificações semestrais, férias vencidas e proporcionais, aviso prévio, licença prêmio paga em rescisão, descansos semanais remunerados, FGTS $8^{\circ}$ mês a mês além da repercussão dessa verba na multa de $40 \%$ de FGTS, tudo conforme restar apurado em execução.

Por todo o exposto, pleitea a reclamante:
a) horas extras em número de 60 (sessenta) por mês, acrescidas com adicional de $50 \%$ :
$\mathrm{R} \$ 45.432,00$
b) integração das horas extras nos $13^{\circ}$ salários:
$\mathrm{R} \$ 3.786,00$
c) integração das horas extras em férias:
$\mathrm{R} \$ 3.786,00$
d) integração das horas extras no terço constitucional:
$\mathrm{R} \$ 1.262,00$
e) integração das horas extras - aviso prévio:
$\mathrm{R} \$ \quad 757,00$ 
f) integração das horas extras - licença prêmio:

$\mathrm{R} \$ 1.514,00$

g) integração FGTS - ítens a, b, f:

$\mathrm{R} \$ 4.058,00$

h) integração FGTS - 40\% sobre ítem g:

$\underline{\mathrm{R} \$ 1.623,00}$

i) juros e correção na forma da lei

total $\mathrm{R} \$ 62.218,00$

\section{ISENÇÃO DE RECOLHIMENTOS FISCAIS E PREVIDENCIÁRIOS}

O salário tem caráter alimentar, gerando prestação mensal obrigatória a teor da lei (art.459, CLT), face sua imediata finalidade satisfativa de subsistência.

Daí resulta que as prestações retidas mensalmente e somente pagas com atraso, acumuladamente, por contrariarem a regra da imediata obrigação satisfativa, passam a ter natureza jurídica indenizatória.

A natureza indenizatória desse pagamento afasta a incidência de descontos fiscais e previdenciários, à semelhança do que ocorre com o pagamento de férias e licença prêmio, não gozadas (Súmulas 136 e 125 do SUPERIOR TRIBUNAL DE JUSTIÇA). A própria legislação tributária e também a previdenciária, como sabido, excluem a paga de natureza, indenizatória da incidência de descontos fiscais e previdenciários.

Por consequência, pleitea a Reclamante que sobre as horas extras vindicadas, não incida qualquer desconto a título de Imposto de Renda e Contribuições Previdenciárias

Na eventualidade de não ser acolhido o pedido supra, pleitea o reclamante que o reclamado em mora seja compelido a responder, a título de perdas e danos, pelas diferenças entre o valor do crédito trabalhista, objeto de tributação, e 
contribuições previdenciárias, e os valores que seriam efetivamente devidos pela reclamante, nas épocas próprias, com os abatimentos e isenções previstos em lei, a serem apuradas em liquidação perante esse Juízo.

\section{DA ÉPOCA PRÓPRIA PARA CORRECÃO MONETÁRIA}

De fundamental destacar que o Banco-reclamado efetua a paga dos salários de seus milhares de funcionários ativos e inativos no dia 20 de cada mês, portanto dentro do próprio mês de competência.

Portanto, não se utilizando o Banco-reclamado da faculdade prevista no artigo 459, $\S 1^{\circ}$, da C.L.T., para a paga normal dos salários de seus funcionários, não poderá esse se favorecer desse instituto, em se tratando de crédito de natureza judicial, sob pena de se estabelecer quebra ao princípio da igualdade de tratamento.

E ainda, dado que o critério de pagamentos do Bancoreclamado se realizava no próprio mês da contraprestação, essa condição mais benéfica não poderá ser substituída pelos índices de correção monetária do mês subsequente, sob pena desta Justiça Especializada derrogar a vontade das partes que contempla norma do empregador mais favorável ao empregado.

(21)

Destarte, requer a reclamante seja fixada a época própria àquela do efetivo mês da prestação de serviços já que os salários do pessoal ativo e inativo do Banco-reclamado são pagos no dia 20 de cada mês.

Ante o exposto, é a presente Reclamação Trabalhista proposta com fundamento nos artigos 837 e 842 da Consolidação das Leis do Trabalho, para que se digne Vossa Excelência determinar as notificações das reclamadas, na pessoa de seus representantes legais, para que, querendo, manifestem-se sobre os termos da presente ação, ou venham conciliarem-se com o reclamante, em audiência de instrução e julgamento a ser designada, sob pena de revelia e confissão quanto a matéria de fato, acompanhando-a até final decisão que deverá julgá-la procedente, condenando as reclamadas aos pagamentos 
das verbas pleiteadas, acrescidas de juros e correção monetária, custas e demais cominações de estilo.

Protestando provar o alegado por todos os meios de prova em direito admitidas, em especial pelo depoimento pessoal dos representantes legais das reclamadas, sob pena de confesso, oitivas de testemunhas e outras que se fizerem necessárias.

(24)

Dá- se à causa o valor de $\mathrm{R} \$ 62.218,00$ (sessenta e dois mil duzentos e dezoito reais).

Pede deferimento, respeitosamente

São Paulo, 19 de Março de 2.003 


\section{ANEXO C}

Demais petições analisadas 


\title{
ANEXO C
}

\section{DEMAIS PETIÇÕES ANALISADAS ${ }^{57}$}

TEXTO 1 - carta introdutória

Exmo. Sr. Dr. Juiz Presidente da $28^{a}$ Junta de Conciliação e Julgamento do São Paulo Proc. No. 1.350/98.

MÁRCIO CAMPOS, nos autos da reclamação trabalhista ajuizada contra ACATEC COMÉRCIO E REPRESENTAÇÕES LTDA, inconformado, data maxima venia, com a r.sentença de fls. 30/31, vem respeitosamente manifestar recurso ordinário para o E.TRT/SP, consoante razões anexas.

Do regular processamento do apelo, regular, tempestivo e isento de preparo,

\author{
P.Deferimento.
}

São Paulo, 05 de outubro de 1998.

Pp.

\footnotetext{
${ }^{57}$ Os textos foram mantidos tais quais originalmente redigidos. Excluíram-se as longas citações de fontes jurídicas diversas que, embora se constituam marcas interdiscursivas importantes que apontam para os interdiscursos jurídicos, não são objeto de análise específica. Os nomes dos trabalhadores reclamantes são fictícios. Assim como na Petição para pedido de hora extra no Anexo B, a numeração dos parágrafos foi acrescida para facilitar a localização dos segmentos analisados.
} 


\section{TEXTO 1}

Pelo recorrente:

MÁRCIO CAMPOS.

\section{EGRÉGIO TRIBUNAL REGIONAL DO TRABALHO}

(1) Merece reforma a r.decisão de primeiro grau. Senão, vejamos.

(2) Tendo sido apresentado em audiência, dia 11.09.98, o documento de fls. 26, o reclamante no final do mesmo dia protocolou diretamente na I. Secretaria da Junta petição através da qual impugnou o documento em referência, desde que a expressão "pagar aviso", nele inserida, não foi pela empresa aposta na via entregue ao autor, através da qual fora manifestada concordância, sem qualquer reserva, a propósito do pedido de dispensa de cumprimento de aviso prévio, formulado no pedido de demissão em questão.

(3) No entanto, muito embora a lei conceda à parte contra a qual foi produzido o documento o prazo de cinco dias para sobre o mesmo se manifestar (art. 398 do CPC), certo é que, na petição anexada à contra-capa dos autos, foi proferido o seguinte despacho: considerando os termos da ata de audiência de fls.11, devolva-se à peticionária, SP, 11.09.98.

(4) Ora, E.Turma, ao indeferir a juntada de petição na qual o reclamante apresentava e fundamentava impugnação a documento apresentado pela parte contrária, antes mesmo de iniciado o prazo legal, o MMo. Juízo de primeiro grau praticou inadmissível cerceio de defesa, tornado nulos todos os atos praticados após 11.09.98 e, em especial, a r.decisão proferida, ora atacada.

(4) Por isso que,

PRELIMINARMENTE, argúi o recorrente, a 


\section{NULIDADE DO JULGADO}

de primeiro grau, em razão de insuperável cerceamento de defesa sofrido com o indeferimento de juntada de petição, apresentada antes de iniciado o prazo legal de 5 (cinco) dias para ouvir o reclamante sobre documento apresentado pela reclamada.

(5) Com efeito, dispõe o art. 398 do CPC, “in verbis”:

(6) "Sempre que uma das partes requerer a juntada de documento aos autos, o juiz ouvirá, a seu respeito, a outra, no prazo de cinco (5) dias”.

(7) No entanto, violando expressa disposição legal, o MMo. Juízo “a quo” indeferiu a juntada. Nem se diga que, na ata de fls. 11, o reclamante teria sido ouvido a propósito do documento em tela, o que realmente não se deu, nada absolutamente tendo sido consignado a respeito.

(8) Assim, impõe-se, data maxima venia, seja anulada a r.sentença recorrida, para o fim de ser apreciada a impugnação pelo autor apresentada a documento trazido com a defesa, proferindo-se novo julgamento.

(9) No entanto, caso diferentemente concluam os Eméritos Julgadores, o que se admite apenas por amor ao argumento, ainda assim quanto ao

(10) MÉRITO:

A reforma do julgado se impõe!

(11) Com efeito, a inadimplência dos depósitos compulsórios, na conta vinculada do reclamante pelo sistema do FGTS é confessada em defesa.

(12) No entanto, pretende a reclamada lhe seja lídimo exercer a compensação de suposto aviso prévio, não concedido pelo obreiro (quando a tanto fora o mesmo 
dispensado) e $13^{\circ}$ salário, com depósitos de FGTS não realizados no momento oportuno, a empregado demissionário.

(13) Ora, Srs. Julgadores, o FGTS deve ser depositado. Não prevê a lei possa o valor respectivo ser pago ao empregado demissionário, máxime em temerária tentativa de ver compensado aviso prévio de empregador, quando fora manifestada concordância com a liberação do mesmo.

(14) Por outro lado, a pretensão patronal, acolhida pelo julgado recorrido, em ver contada correção monetária e juros sobre débito de empregado é inconstitucional, desde que não há lei prevendo tal procedimento. Tais encargos são legalmente previstos para incidir sobre débito do empregador. Nenhuma lei os estabeleceu para o empregado. Assim, somente com ofensa ao princípio constitucional da legalidade, poder-se-ia admitir tal incidência sobre débito do empregado.

(15) Note-se, por oportuno, que a defesa não apresentou qualquer objeção ao quadro demonstrativo trazido com a inicial às fls. 9. No entanto, o MMo. Juízo "a quo" aceitou o montante indicado no quadro 27, do TRCT de fls. 29, sem qualquer demonstração, para ensejar a ilícita compensação postulada na contestação ofertada. Ora. Srs. Julgadores, à míngua de impugnação ao quadro elaborado, injusta sua inaceitação pelo MMo. Juízo de origem.

(16) Face ao exposto, é de se esperar pelo acolhimento da preliminar de nulidade do julgado, por manifesto cerceio de defesa, devendo os autos retornarem para a MMa. Junta de primeiro grau, para o fim de ser proferido novo julgamento, com a apreciação da tempestiva impugnação apresentada pelo autor, sobre documento trazido com a defesa, salvo se, pelo mérito, houver por bem esta C.Turma julgar inadmissível a compensação pretendida pelo empregador, hipótese que levará ao provimento deste apelo, para o fim de julgar procedente a ação, tudo como de direito e de JUSTIÇA.

São Paulo, 05 de outubro de 1998.

Pp. 


\section{TEXTO 2}

Exmo. Sr. Dr. Juiz Presidente da $51^{a}$ Junta de Conciliação e Julgamento de São Paulo.

Proc. No. 2057/89

(1) FÁBIO MOREIRA MENDES, nos autos da reclamação trabalhista ajuizada contra BANCO DO ESTADO DE SÃO PAULO S/A, ciente da garantia do Juízo com a intimação de fls. 572, veiculada no D.J. de 15.12 .98 e consoante restou expressamente ressalvado às fls. 563, vem respeitosamente com amparo no artigo 884, parágrafo $3^{\circ}$ da CLT, tempestivamente impugnar a r.sentença de liqüidação de fls. 552, aduzindo para tanto o que segue:

(2) Primeiramente, entende o embargante, data maxima venia, que a realização de desconto (previdenciário e fiscal) sobre seu crédito é inconstitucional, desde que não previsto na decisão exeqüenda e viola a coisa julgada, amparada pelo artigo $5^{\circ}$, inciso XXXVI da Constituição Federal.

(3) Na verdade, somente com ofensa à coisa julgada, poderiam tais deduções ser autorizadas. Nesse sentido, expressiva manifestação jurisprudencial:

(4) $[\ldots]$

(5) Mas, ainda que tal óbice pudesse em tese ser superado, o que se admite apenas para argumentar, certo é que o Sr. Perito deveria observar em relação ao imposto de renda o mesmo critério utilizado quanto à cota previdenciária (fls. 541).

(6) Assim, dever-se-ia atentar aos limites de isenção fixados mês a mês, nos valores originais. Consoante Instrução Normativa no. 131, de 30.12.85, baixada pelo Sr. Secretário da Receita Federal (publicada no D.J. de 31.12.85, fls. 548), foi fixada a quantia de 
Cr\$1.761.000 mensais, como limite de isenção dos rendimentos auferidos a partir de janeiro de 1986. Os valores apurados a título de principal (vide $2^{\text {a }}$ coluna de fls. 542) constituem quantias inferiores a esse limite, não se justificando, portanto, a incidência do tributo. Portanto, se o conceito de "valor mensal da prestação" é prestigiado para fins de INSS (o que somente prejudica o autor, elevando o valor do desconto), não há como deixar de adotar esse mesmo conceito para fins de IR, desde que não foi o autor quem deu azo ao atraso no pagamento, de forma a englobar diversas prestações mensais num só ato.

(7) Assim, na hipótese que, data maxima venia, tem por absurda, ser autorizado o desconto fiscal, haveria de se aplicar a tabela progressiva do imposto às parcelas devidas mês a mês.

(8) Isto posto, aguarda o embargante pelo acolhimento de sua impugnação parcial, para o fim de, reformando-se a r.sentença de liqüidação em estrita obediência ao julgado exeqüendo, desautorizar a realização de descontos previdenciários e fiscais sobre o crédito do autor ou, quando menos, observar a tabela progressiva do imposto de renda, aplicável às prestações mensais, como de direito e de JUSTIÇA.

São Paulo, 07 de janeiro de 1999.

Pp. 


\section{TEXTO 3}

Exmo. Sr. Dr. Juiz Presidente da .. ${ }^{a}$ Junta de Conciliação e Julgamento de São Paulo

(1) JOÃO DE LIMA, brasileiro, casado, montador, portador do RG no. 2.963.817, CTPS no. 80.500, série $630^{\mathrm{a}}$, nascido em 05.09.1930, residente e domiciliado à Rua Ladislau Eugênio Camargo no. 28, Fundos, Vila são José, Osasco (06290-170), vem propor reclamação trabalhista contra ITALINE COMÉRCIO E REPRESENTAÇÕES LTDA., sediada à Rua Caetés, no. 601, Perdizes, em São Paulo (05016-081), pelas razões de fato e de direito a seguir aduzidas.

\section{(2) DAS DECISÕES JUDICIAIS:}

1. Por força de decisões judiciais transitadas em julgado nos autos dos Processos no. 632/94 e no. 2800/96, que tramitaram perante a $13^{\mathrm{a}}$ e $64^{\mathrm{a}}$ JCJs de São Paulo, respectivamente (docs. 1 e 2), foi reconhecida relação de emprego a partir de 01.09.1983, entre o reclamante e a reclamada - sucessora de Tati Comércio e Represetanções Ltda. tendo mais, sido determinado o pagamento de salários desde o afastamento (01.04.95) até a obtenção de licença previdenciária ou eventual alta, in verbis:

\section{(3) $[\ldots]$}

\section{DO ACORDO JUDICIAL:}

2. As partes se conciliaram perante a $13^{\mathrm{a}} \mathrm{JCP} / \mathrm{SP}$ (doc.3) quitando o reclamante o processo que lá tramitava e, parcialmente, os direitos decorrentes da condenação havida nos autos do processo que tramita perante a $64^{\mathrm{a}} \mathrm{JCP} / \mathrm{SP}$. Isto porque a quitação se estendeu apenas até o mês de agosto/97. Inclusive, a ré se comprometeu a realizar os recolhimentos previdenciários no período de 09/83 a 07/97 e a fornecer a Relação dos Salários de Contribuição. Conforme cláusula $5^{\text {a }}$ do acordo homologado, estabeleceu que:

\section{(4) $[\ldots]$}




\section{DA DISPENSA:}

3. Ocorre porém que, após inúmeras diligências junto ao órgão previdenciário, o reclamante não logrou êxito na concessão de auxílio-doença previdenciário, nem tão pouco de aposentadoria por tempo de serviço.

(5) 4. Por isso, em 30.06.98, o reclamante colocou-se à disposição do empregador para reassumir suas funções, desde que não houve qualquer ruptura do liame empregatício.

(6) 5. Todavia, através de petição datada de 11.08 .98 (doc. 4), a reclamada manifestou expressamente sua intenção em não manter o reclamante em seus quadros, o que equivale à comunicação de dispensa. No entanto, até a presente data, a reclamada não efetivou o pagamento de salários vencidos, nem das verbas rescisórias. Assim, resta assegurada a multa por atraso, prevista no artigo 477 da CLT.

\section{(7) DA REMUNERAÇÃO:}

6. Consoante restou firmado pelo laudo homologado no processo trabalhista que tramitou perante a 1 J JCP/SP (doc. 5), o salário do reclamante em dezembor/94 importava em $\mathrm{R} \$ \mathbf{8 0 5}, 51$. Assim, de acordo com os reajustes estabelecidos na cláusula primeira dos dissídios coletivos da categoria profissional do reclamante (docs. 6/8), deve ser observada a seguinte evolução salarial:

(8) $[\ldots]$

Portanto, o salário a ser observado para pagamento das verbas rescisórias corresponde a R\$1.163,64.

\section{(9) DO AVISO PRÉVIO ESPECIAL:}

7. De acordo com o estabelecido pela cláusula $25^{\text {a }}$ do dissídio coletivo, vigência 97/98 (doc. 08), faz jus o reclamante ao aviso prévio especial de 45 dias, desde que se 
enquadra na hipótese ali prevista por contar, à época da dispensa, com mais de 45 anos de idade.

\section{(10) DAS FÉRIAS:}

8. Conforme anteriormente esclarecido, a quitação outorgada no referido acordo estendeu-se até o mês de agosto/97, inclusive. Desse modo, faz jus o autor ao pagamento de férias vencidas relativas ao período de 01.09.97 a 01.09.98, acrescidas do terço constitucional, eis que a dispensa ocorreu em 11.08.98. Deve ser ressaltado que o pagamento dos salários do período de 01.09.97 até a dispensa somente será exigido nos autos do processo que tramita perante a $64^{\mathrm{a}} \mathrm{JCP} / \mathrm{SP}$, em decorrência da condenação havida naqueles autos.

\section{(11) FACE AO EXPOSTO PLEITEIA:}

\section{$[\ldots]$}

Requer a notificação da reclamada para, querendo, responder aos termos desta reclamação trabalhista, sob cominação de, se revel, aplicar-se-lhe a pena de confissão, devendo ao final ser julgado procedente o pedido, acrescido de juros e correção monetária, além de custas e demais despesa processuais.

(12) Protestando pela produção de todos os meios de prova em direito permitidos, dá à presente o valor de $\mathrm{R} \$ 12.500,00$.

São Paulo, 10 de dezembro de 1998.

Pp. 


\title{
ANEXO D \\ Modelos de formulários que compõem o processo trabalhista $^{58}$
}

Os seguintes modelos de formulários são apresentados nas páginas seguintes, na ordem abaixo (que corresponde à ordem de utilização durante o processo, quando necessário):

\author{
Citação \\ Intimação ao autor \\ Intimação para depoimento \\ Intimação \\ Registro de Audiência \\ Termo de audiência \\ Termo de audiência e sentença \\ Termo de adiamento de audiência \\ Termo de declaração \\ Conclusão \\ Termo de arquivamento de reclamação \\ Termo de compromisso de depositário
}

\footnotetext{
58 À época da seleção do material para análise, ainda havia no Direito Trabalhista a categoria "juiz classista”, recentemente abolida. Trata-se, como vimos, de figura atípica no Direito, mas por um tempo necessária no Direito Trabalhista devido às suas condições históricas de surgimento.
} 


\section{CITAÇÃO}

Fica V. Sa. citado para responder aos termos da Açăo proposta por , conforme

cópia da petiçăo inicial que segue anexa, devendo fazê-lo na audiência designada para às horas, oportunidade em que deverá oferecer

defesa escrita, bem como as provas que entender necessárias, constantes de documentos e testemunhas, estas no máximo de três.

É facultado a V. Sa. fazer-se substituir em audiência por um preposto que tenha conhecimento direto dos fatos; o năo comparecimento de V. Sa. ou preposto autorizado produzirá os efeitos previstos no art. 844 da CLT.

Endereço do Juízo:

Em 
Processo $n^{\circ}$

Autor: (o destinatário)

Réu:

\section{INTIMAÇÃO AO AUTOR}

Fica $V$. Sa. intimado a comparecer perante este Juizo no dia

às horas, para audiência relativa ao processo acima mencionado.

Nessa audiência deverá V. Sa. oferecer as provas que entender necessárias, constantes de documentos e testemunhas, estas no máximo de três.

O năo comparecimento de $V$. Sa. importará na extinçăo do processo.

Endereço do Juizo:

Em

$1-$ IN $-3-01$

Diretor (a) de Secretaria 
Processo $n^{\circ}$

Autor:

Réu:

\section{INTIMAÇÃO}

Fica V. Sa. intimado a comparecer perante este Juizo para prestar depoimento como testemunha arrolada por

em audiência designada para às horas.

Seu não comparecimento poderá implicar em condução coercitiva, além de multa.

Endereço do Juizo:

Em 
Processo $\mathrm{n}^{\circ}$

\section{AUTOR:}

RÉU:

Fica V. Sa. INTIMADO para o constante do item

01 - Tomar ciência da sentença, conforme cópia em anexo.

02 - Tomar ciência da decisão, conforme cópia em anexo.

03 - Designaçăo de Audiência para às horas, para prestar depoimento sob pena de confissão.

04 - Designação de Julgamento para publicada em audiência.

05 - Designação de Julgamento para 1 às horas.

06 - Apresentar cálculos de liquidação em dias.

07 - Contestar cálculos de liquidaçăo (art. 879 paragrafo $2^{\circ}$ da CLT).

08 - Contra-arrazoar Recurso Ordinário.

09 - Contra-arrazoar Recurso Adesivo.

10 - Contra-minutar Agravo de Instrumento.

11 - Contra-minutar Agravo de Petição.

12 - Responder aos Embargos à Execuçăo.

13 - Responder aos Embargos de Terceiro.

14 - Realização de praça para o dia de e, se negativa, leilão para o dia de de às horas,

15 - Tomar ciência de às horas. 16 -

Em Diretor (a) de Secretaria 


\section{PODER JUDICIÁRIO FEDERAL Justiça do Trabalho - $2^{\text {a }}$ Região}

\section{2 $2^{\mathrm{a}}$ JUNTA DE CONCILIAÇÃO E JULGAMENTO DE SÃO PAULO \\ PROC. $N^{0} 3033 / 96$}

Aos 9 dias do mês de junho de mil, novecentos e noventa e sete, às 12,15 horas, na sala de audiências desta Junta, sob a presidência do MM. Juiz do Trabalho Dr. LUIZ EDGAR FERRAZ DE OLIVEIRA, presentes os Srs. IARA S S GALLUCCI, Juiz Classista Representante dos Empregadores e ANTONIO CARLOS DUARTE, Juiz Classista Temporário Representante dos Empregados, foram por ordem do MM Juiz apregoados os litigantes:

MANOEL GONÇALVES RIBEIRO, recte e BAR E RESTAURANTE ESTAÇÃO VILA BAR LTDA, recda.

Presente o recte com o(a) $\operatorname{Dr}(a)$. Mario L R de Oliveira, OAB/SP 90601, que pede prazo de 5 dias para a juntada de substabelecimento. Deferido. Presente a recda pelo sócio, Ana Cristina Moutela Costa com o(a) Dr(a). Alvaro P P Prazeres, OAB/SP 92949.

Conciliação rejeitada. Defesa escrita com documentos, dos quais teve vista o recte em audiência.

DEPOIMENTO DO RECTE: Interrogado, respondeu que trabalhava todos os dias no horário das 16 às 1 hora da manhã, de domingo a domingo, tinha 2 folgas por mês e intervalo de meia hora; 0 depoente era garçon e na recda havia 3 garçons, ou seja, o depoente mais 2, cujos nomes não se lembra agora; os referidos garçons trabalhavam no mesmo horário que o depoente; sempre recebeu o pagamento em dinheiro; recebeu $R \$ 80,00$ quando saiu da empresa; o depoente foi dispensado pela dona da empresa, cujo nome não se lembra e o fato não foi testemunhado. Nada mais.

DEPOIMENTO DA RECDA: Interrogado, respondeu que o recte não ia trabalhar todos os dias na recda e sim quando ia participar de alguns eventos especiais para cobrir alguma folga; a recda fazia exposições a cada 3 meses na época do recte e a recda chamava o recte nessas ocasiões mandando recados por algum funcionário; o recte também cobria as folgas de outros empregados e ele era avisado antes; o recte trabalhava entre 22 às 2 horas da manhã. Nada mais.

As partes não têm testemunhas.

A recda propôs acordo de $\mathrm{R} \$ 900,00$ em 2 parcelas e foi recusado pelo recte.

Encerrada a instrução processual. Proposta final conciliatória rejeitada. Razões finais em até 10 dias antes da audiência de julgamento, designada para o dia 12/11/97 às $15 \mathrm{~h}$, tomando as partes ciência da decisão na secretaria da Junta, nos termos do En 197 do TST. Cientes. NADA MAIS. 
PODER JUDICIÁRIO FEDERAL

Justiça do Trabalho - 2a Região

JUNTA DE CONCILIAĢ̃̃O E JULGAMENTO DE

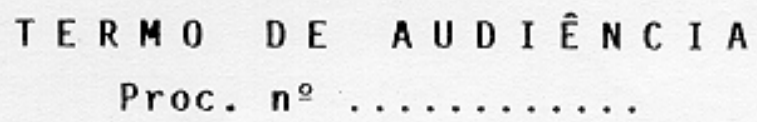

Aos dias do mês de do ano de mil novecentos e

às $\ldots . . . . \mathrm{hs}$, na sala de audienncias desta Junta, sob a presidência do MM. Juiz do Trabalho, Dr. Juiz Classista Temporário Representante dos Empregadores

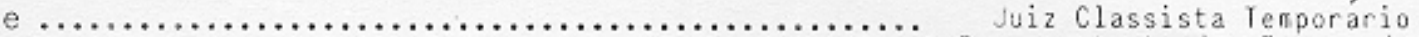

foram, por onden do M. Juiz Presidente, apregoados os litigantes. 


\section{TERMO DE AUDIENCIA}

Aos
Proc. NO

horas, presidida

pelo MM. Juiz do Trabalho Dr.

realizou-se a audiência referente ao processo acima, entre partes

Compareceu o recte.

Ausente a recda., que é revel e confessa. O recte. confirmou os termos da inicial

Prejudicada a conciliação. Submetida a reclamação a julgamento, foi proferida a seguinte

\section{SENTENÇA}

Reclamação de

Pede

A recda. é revel e confessa quanto à matéria de fato. Ouvido o recte.

Prejudicada a conciliação.

\section{DECIDIMOS}

A confissão ficta da recda. faz presumir verdadeiros os fatos alegados na inicial.

Isto posto, a J.C.J. de São Paulo, à unanimidade, JULGA a reclamação PROCEDENTE

Conseqüentemente, fica a recda. condenada no pedido

Juros de mora e correção monetária na forma da lei. Custas pela Recda., calculadas sobre RS no importe de RS

- Ciente o recte. Intime-se a recda. 


\section{PODER JUDICIÁRIO \\ Justiça do Trabalho \\ TRIBUNAL REGIONAL DO TRABALHO DA 2 "REGIÄO \\ SÃO PAULO - SP \\ JUNTA DE CONCILIACCÃO E JULGAMENTO \\ TERMO DE ADIAMENTO DE AUDIENCIA}

Proc. no

Aos dias do mês de

do ano de mil novecentos e nesta cidade de às horas, na sala de audiências desta Junta, presente - Reclamante

(representaçäo quando houver

e $\frac{\text { presente }}{\text { ausente }}$ a Reclamada

(representaçấo quando houver)

não se tendo podido realizar a audiência para apreciação da reclamação pelo primeiro apresentada contra o segundo, em razão de

ficou marcada nova audiência para o dia de de 19 às horas.

Do que, para constar, foi lavrado o presente termo, que vai assinado pe lo MM. Juiz Presidente e por mim, Diretor da Secretaria, subscrito.

Juiz Presidente

Diretor da Secretaria

Reclamada :

Reclamante : 


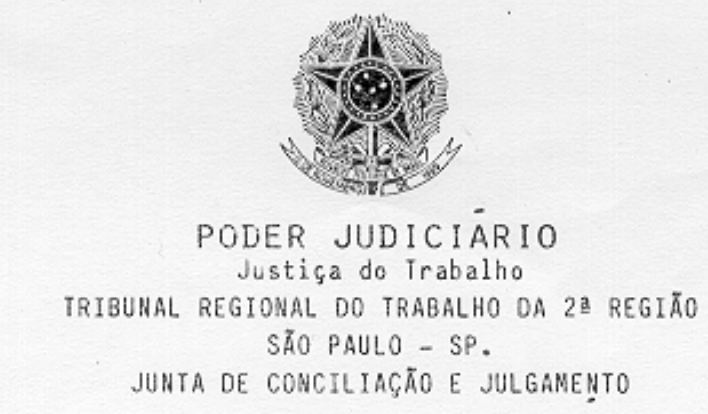

FLS.

\section{TERMO DE DECLARAÇĀO}

Proc. no

Aos

dias do mês de

de mil novecentos e perante mim, Diretor da Secretaria,

compareceu o

e por ele me foi dito que:

E, para constar, foi lavrado o presente termo, que vai assinado pelo declarante e por mim, Diretor da Secretaria, subscrito.

Declarante 
Proc.

Rte.

Rdo.

Em

Nesta data, tendo sido determinada a baixa dos presentes autos, deles verifiquei constarem folhas, devidamente numeradas e rubricadas.

Custas $\frac{\text { isentas }}{\text { pages }}$ às $\mathrm{fls}$.

Remeto-os, assim, ao Arquivo Geral.

Em 


\section{PODER JUDICIÁRIO}

Justiça do Trabalho

TRIBUNAL REGIONAL DO TRABALHO DA 2: REGIÃO

SÃO PAULO - SP

JUNTA DE CONCILIAÇÄO E JULGAMENTO

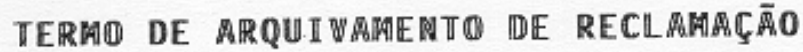

Proc. $n \cong \ldots \ldots \ldots \ldots$.

RECLAMANTE :

RECLAMADA :

Aos $\ldots \ldots \ldots \ldots \ldots \ldots \ldots \ldots$ dias do més de $\ldots \ldots \ldots \ldots \ldots$ do ano

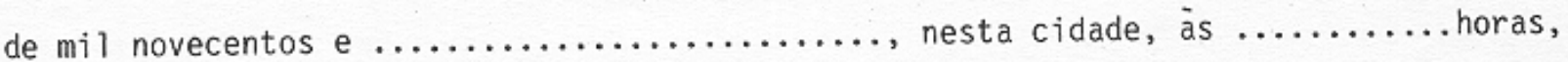
na sala de audiências, não tendo comparecido o reclamante, foi pelo MM. Juiz Presidente arquivada a reclamação, nos termos do art. 844 da Consolidaçäo das Leis do Trabalho.

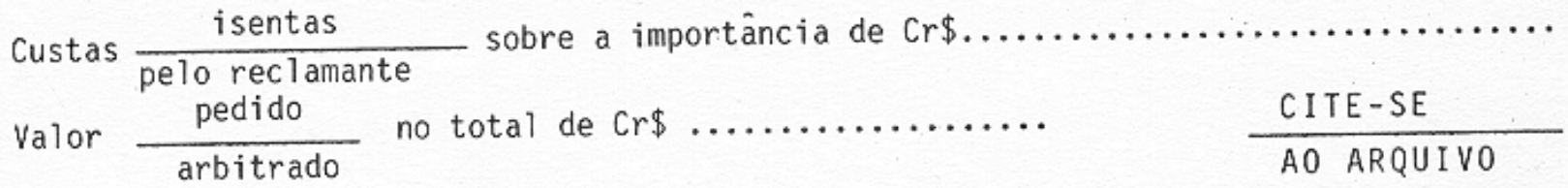

Do que, para constar, foi lavrado o presente termo, que vai assinado pe 10 MM. Juiz Presidente e por mim, Diretor da Secretaria.

Juiz Presidente

Diretor da Secretaria 


\section{TERMO DE COMPROMISSO DE DEPOSITÁRIO}

Aos

$$
\text { dias do mês de }
$$

do ano de 19

compareçeu perante mim, Diretor da Secretaria da

Junta de Conciliação e Julga- o Sr.

indicado como depositário pel (a) reclamante (reclamada), portador da C.I. Número , residente à

e, como tal, se obriga a não abrir mão dos bens penhorados e avaliados, sem autorização do MM. Juiz Presidente, sob as penas da Lei. Feito, assim, o depósito, para constar foi lavrado o presente termo, que vai assinado.

Diretor da Secretaria 


\section{ANEXO E}

Carta-convite ao escritório de advocacia trabalhista 


\section{ANEXO E \\ CARTA CONVITE AO ESCRITÓRIO DE ADVOCACIA TRABALHISTA}

São Paulo, outubro de 2002

Ilmo. Sr. Dr. Walter Sampaio e

Ilma. Sra. Dra. Iara Sampaio

Mendonça Sampaio Advogados Associados

Prezados Senhores,

Venho solicitar de V.Sas. sua prestimosa colaboração dentro de sua especialidade (direito trabalhista) ao projeto de doutorado de minha orientanda Tatiana Piccardi, cujo trabalho, de caráter interdisciplinar, ganhará em solidez se puder contar com a sua participação.

A tese que Tatiana desenvolve sob minha orientação intitula-se "A representatividade discursiva da voz do trabalhador no universo do trabalho: a petição trabalhista como expressão máxima dessa representatividade”. Neste trabalho, desenvolvido a partir de pano de fundo teórico que valoriza as relações linguagem $\mathrm{x}$ sociedade, a autora levanta a hipótese de que é nas petições trabalhistas que a voz do trabalhador encontra, no universo do trabalho como um todo, maior expressividade lingüístico-discursiva (ou seja, evidenciada no texto). Numa época em que, no Brasil, se apregoa a igualdade de relações capital x trabalho, constata-se que de fato tal igualdade não existe, pois as possibilidades de expressão de vozes menos ligadas ao capital continuam mínimas. Assim sendo, é oportuno investigar como a voz do trabalhador se constrói lingüisticamente nos textos de caráter oficial e legal em que mais aparece, em especial na petição trabalhista, e como procura marcar seu espaço nas relações capital x trabalho.

Para que tal estudo se realize com a seriedade e a profundidade que o tema merece, é importante que a autora se familiarize mais com o Direito Trabalhista e a sua prática, a fim de que não incorra em erros de análise. A contribuição de V.Sas. consistiria basicamente em autorizar a autora a acompanhar um advogado de sua equipe nas diferentes fases de um processo trabalhista (a ser escolhido posteriormente mediante alguns critérios), gravando as falas do trabalhador envolvido na causa e tendo acesso aos textos escritos produzidos durante o processo, a fim de certificar-se de sua hipótese e proceder ao seu desenvolvimento. Solicitamos ainda alguma disponibilidade para esclarecer-lhe as dúvidas que certamente surgirão.

Sem mais, desde já grata pela atenção, e acreditando que os trabalhos acadêmicos desenvolvidos em parceria com aqueles que possuem a experiência da vida prática podem trazer contribuições ainda mais substanciais à sociedade, despeço-me aguardando seu parecer favorável.

Atenciosamente,

Profa. Dra. Helena H. Nagamine Brandão

Programa de Pós-graduação em Filologia e Língua Portuguesa / USP 